\title{
The Intervention of Philology
}

Gender, Learning, and Power in Lohenstein's Roman Plays

Jane O. Newman 
The Intervention of Philology 
From 1949 to 2004, UNC Press and the UNC Department of Germanic \& Slavic Languages and Literatures published the UNC Studies in the Germanic Languages and Literatures series. Monographs, anthologies, and critical editions in the series covered an array of topics including medieval and modern literature, theater, linguistics, philology, onomastics, and the history of ideas. Through the generous support of the National Endowment for the Humanities and the Andrew W. Mellon Foundation, books in the series have been reissued in new paperback and open access digital editions. For a complete list of books visit www.uncpress.org. 


\section{The Intervention of Philology Gender, Learning, and Power in Lohenstein's Roman Plays}

JANE O. NEWMAN

UNC Studies in the Germanic Languages and Literatures Number 122 
Copyright (C) 2000

This work is licensed under a Creative Commons CC BY-NC-ND license. To view a copy of the license, visit http://creativecommons. org/licenses.

Suggested citation: Newman, Jane O. The Intervention of Philology: Gender, Learning, and Power in Lohenstein's Roman Plays. Chapel Hill: University of North Carolina Press, 2000. DOI: https://doi.org/ 10.5149/9781469658087_Newman

Library of Congress Cataloging-in-Publication Data

Names: Newman, Jane O.

Title: The intervention of philology : gender, learning, and power in Lohenstein's Roman plays / by Jane O. Newman.

Other titles: Other titles: University of North Carolina Studies in the Germanic Languages and Literatures.

Description: Chapel Hill : University of North Carolina Press, [2000] Series: University of North Carolina Studies in the Germanic Languages and Literatures Includes bibliographical references and index.

Identifiers: LCCN 99-40597 | ISBN 978-0-8078-5746-5 (pbk: alk. paper) | ISBN 978-1-4696-5808-7 (ebook)

Subjects: Lohenstein, Daniel Casper von, 1635-1683 - Criticism and interpretation. | Lohenstein, Daniel Casper von, 1635-1683 Characters - Women. | Lohenstein, Daniel Casper von, 1635-1683 - Knowledge - Rome. | Historical drama, German - History and criticism. | Power (Social sciences) in literature. | German drama - Roman influences. | Sex role in literature. | Women in literature. | Rome - In literature.

Classification: LCC PT1745 .L5N49| DDC 832/.5 - dc21 


In Memory of My Parents,

Andrew Joseph Newman Jr. (1917-99) and

Dorothy Ogden Newman (1919-94) 


\section{Contents}

Preface $\quad x i$

Textual Note $\quad$ XV

Introduction. Gender, Knowledge, Philology:

The Case of Daniel Casper von Lohenstein

Lohenstein at the Crossroads: Early Modern Studies and the Politics of Location

Philology and the Construction of Early Modern

Gender Identity

The Worlds of Daniel Casper von Lohenstein

1. Sophonisbe (1669) and the Text That Is Not One:

Hybridity in Historiography

Playing with History: The Past That Is Not One 37

Playing with Gender: Sexual/Textual Cross-Dressing 47

Dido, Sophonisbe, and the Philological (Re)Production of Gender

The Play That Is Not One

2. Sex "in Strange Places": Sexed Bodies and the Split Text of Lohenstein's Epicharis (1665)

Academic Bodies and the Early Modern (Fe)Male Subject

Sex "in Strange Places": Sexual and Textual Confusion

Staging Ambiguity: The Question of Epicharis's

Tortured Body

The Text That Is Not One: Lohenstein's Tacitus

3. Agrippina (1665) and the Politics of Philology: Sons and Mothers in Early Modern Central Europe

Sons and Mothers in Early Modern Central Europe 101

Semiramis and Agrippina: Matricide in the Margins 


\section{$\mathrm{x}$ Contents}

Women in Power: Gender Stereotypes and the Politics of Philology

4. Lohenstein's Cleopatra (1680): "Race," Gender, and the Disarticulation of the Early Modern Imperial Subject

Discourses of "Race" in the Early Modern Period

"No Servile Moor"?: Race and Gender in Cleopatra

The Empire Talks Back: Blazons and the Dark Body 146

The Politics of Textual Resistance

Conclusion. Philology, Lohenstein, and the Post-Baroque

Benjamin and the Post-Baroque

Lohenstein on the Border: Klaus Günther Just's

Cold War Edition

Recentering Europe in Early Modern Studies 175

Notes

Bibliography

Index 


\section{Preface}

This book took on its initial parameters in Tübingen, in the early 1990s, in a Germany that was still newly experiencing the excitement, yet also the disorientations and challenges associated with finding itself "enlarged" once again to the east. It was a Germany still living in the shadow of the Cold War, however, in spite of recent events that were supposed to have made such bilateralisms a thing of the past. The book was brought to conclusion in Berlin in the late 1990s, in a Germany that stands poised to embark upon the new age of the Berlin Republic. In the fall of 1998, newly elected federal officials made a point of traveling immediately to both London and Warsaw (although in that order) to demonstrate their awareness of the new kinds of axes and the new "European" vision necessary for a new "postnationalist" age; the new European currency, the Euro, was introduced to great fanfare on January 1, 1999, and discussions of the eastward expansion of NATO are the stuff of the most important international diplomatic exchanges. In spite of such initiatives, however, it is not clear that the borders that marked the geographies of interest, energy, and resources that organized Europe and the globe over the nearly half a century preceding the Wende, or "turn" of 1989, have really disappeared, if they ever actually could. Rather, they appear to me to have merely gone underground.

My perception of the subliminal pressures to think still in terms of an east and west of Europe may well be the result of completing this book in a no-longer-divided but still-divided-in-the-mind city; "die Mauer ist noch im Kopf" (the Wall still exists in the mind). But Berlin is the new capital city, the future "center of Europe," and thus provides a model in more ways than one for the direction that Germany and, some say, the continent will take. If this is the case, then we must consider the fact that the vast majority of longtime residents whom I meet have never been to Poland, although the border lies just an hour or so away; many still speak of going to "Westdeutschland" when they travel beyond the city limits in the direction of Munich, Frankfurt, or Hamburg. Conversely, talking to residents of Wittenberg, also just an hour away and in the former East, reveals that they have no interest in coming to Berlin. It is too "western," too on-the-make; they prefer their way of life. The old divisions and attitudes will die hard in a world that is still organized as much by East-West as by North-South polarities.

As I ponder the fate of Europe and wonder what shape any future 
study of the kinds of eastern central European historical and cultural phenomena that are the subject of this book will take, especially in the United States, the continuing westward tilt of the academic, political, and cultural map becomes increasingly apparent, even as Europe and its borders and responsibilities become ever larger and more complex. What are we to make of charges of "Eurocentrism" when, even within Europe, half of the countries and cultures of the continent that goes by that name are invisible to most in the West? Can we still speak of the effects of "Western ideology" when some of its most avid advocates live and work in the East? What role will the "new Europe" take in the overall reinvention of geopolitics in the twenty-first century, and how will the United States respond? In more ways than one, this book is a plea to think about these questions more slowly, historically. Coming from a scholar whose main place of employment is a large state university on the so-called West Coast of the North American continent, a West that has its face turned as often as not to the so-called East, it is a call to reconsider-indeed, even to redraw-some of the maps on which we have come to rely over at least the past fifty years. This is not a call for retrenchment or for the rejection of the deserved critiques that the study of Europe has received in the U.S. academy in recent times. Rather, drawing the borders of Europe and "the West" too simply constrains our collective ability to understand the events of our past and the possibilities for our future.

My two sojourns in Germany were made possible by grants from the Alexander von Humboldt Stiftung (1991-92) and the Guggenheim Foundation (1998-99) and I would like to thank those organizations for supporting my research. Grants from the UC Irvine Humanities Center, UCI School of Humanities Committee on Research and Travel, and UCI School of Humanities Dean Karen Lawrence are also gratefully acknowledged.

For intellectual support and stimulating collegiality of many kinds over the years, I thank Dan and Maria Brewer (Minnesota), Walter Cohen (Cornell), Page DuBois (UC San Diego), Bob and Vivian Folkenflik (UC Irvine), Tony Grafton (Princeton), Betty Guthrie (UC Irvine), Tim Hampton (UC Berkeley), Stephen Jaeger (Washington-Seattle), Stephanie Jed (UC San Diego), Coppelia Kahn (Brown), Vicky Kahn (UC Berkeley), Marc Katz (Pomona), Katie King (Maryland-College Park), Christia Mercer (Columbia), Bob Moeller (UC Irvine), Tim Murray (Cornell), Stephen Orgel (Stanford), Leslie W. Rabine (UC Irvine), Gabriele Schwab (UC Irvine), Lynne Tatlock (Washington-St. Louis), Elaine Tennant (UC Berkeley), and Linda Williams (UC Berkeley). A special note 
of undying gratitude goes to Patrick Sinclair (UC Irvine), who was always ready to discuss the fine details of early modern Latin historiographic commentary with me. In Germany, the openness and support shown to me and my work by Wilfried Barner (Göttingen) were without parallel. I also reaped the benefits of conversations with Conrad Wiedemann (Berlin) on several occasions as well as with Walter Erhart (Greifswald). For information about Klaus Günther Just, I would like to thank Jörg-Ulrich Fechner (Bochum) and Hugh Powell (Indiana) for detailed replies to written inquiries. Ewa Pietrzak (Wroclaw) also proved a helpful correspondent. Finally, the support system and goodwill of Pat Adams, Caroline Ehrlich, and Davida Hopkins-Parham of UC Irvine's Office of Academic Affairs made a few nightmarishly busy years into an enjoyable, sometimes hilarious learning experience.

For material and electronic help of many sorts I thank the staff of the following archives and libraries: the Bancroft Library, UC Berkeley; the Bayerische Staatsbibliothek, Munich; the Bodleian Library, Oxford; the William A. Clark Library, UCLA; the Deutsches Literaturarchiv, Marbach; the Herzog August Bibliothek, Wolfenbüttel; the Huntington Library, San Marino; the UC Irvine Library; and the Universitätsbibliothek and the Universitätsarchiv, Tübingen. Dwight Brooks, Carol Hayes, Michael Householder, Melissa Sanchez, and Gina Shaffer of UC Irvine's Department of English and Comparative Literature and Janice Neri of the Department of Visual Studies also deserve a special word of thanks for countless large and small (yet nevertheless crucial) contributions of effort and time. Paul T. Roberge has been an exemplary editor, and I recommend him to all.

Parts of several chapters of this book appeared elsewhere in earlier incarnations, and I am grateful to the editors and publishers of the following journals and collections for permission to reprint selections here: "Innovation and the Text Which Is Not One: Representing History in Lohenstein's Sophonisbe (1669)," in Innovation und Originalität, edited by Walter Haug and Burghart Wachinger, Fortuna vitrea. Arbeiten zur literarischen Tradition zwischen dem 13. und 17. Jahrhundert, no. 9 (Tübingen: Max Niemeyer Verlag, 1992), 206-38; "Sex 'in Strange Places': The Split Text of Gender in Lohenstein's Epicharis," in The Graph of Sex and the German Text: Gendered Culture in Early Modern Germany, edited by Lynne Tatlock and Christiane Bohnert (Amsterdam: Rodopi, 1994), 349-82; "Sons and Mothers: Agrippina, Semiramis, and the Philological Construction of Gender Roles in Early Modern Germany (Lohenstein's Agrippina-1665)," Renaissance Quarterly 49 (1996): 77-113; “Almost White, but Not Quite: 'Race,' Gender, and the Disarticulation of the Imperial Subject in Lohenstein's Cleopatra (1680)," in Signs of the Early 
Modern, edited by David Lee Rubin, Studies in Early Modern France/ EMF Monographs 3: (1997), 1-27, reprint permission granted by the copyright holder, Rookwood Press (Charlottesville, VA); and "Textual Reproduction and the Politics of the Edition: Spellerberg on Just on Lohenstein," in Studien zur Literatur des 17. Jahrhunderts. Gedenkschrift für Gerhard Spellerberg (1937-1996), edited by Hans Feger, Chloe: Beihefte zum Daphnis 27 (1997): 1-24.

For permission to reproduce the illustrations, I would like to thank the Bayerische Staatsbibliothek, Munich, and the Universitätsbibliothek, Tübingen.

It goes without saying, of course, that this entire project would have been impossible without the efforts of John $\mathrm{H}$. Smith, who probably now knows more about Lohenstein, Silesia, Roman history, and early modern philology than anyone outside of the field should really have to. I would also like to thank our children, Jordan and Julian, for allowing me to go to just one more library to look up just a few more things on what were for them probably just a few too many occasions.

I dedicate this book to my parents, Joe and Dorothy Newman, who really did let me go my own way and always supported me, even if I did not really know it at the time. May I be able to replicate that wisdom.

Berlin, Germany

February 1999 


\section{Textual Note}

When citing Lohenstein, I refer to Klaus Günther Just's edition of the plays published by Hiersemann Verlag, 1953-57; his version of Lohenstein thus mediates between several historical moments, including the ones to which both the "originals" of the plays and my readings of them belong. The plays are cited parenthetically within the text by page and line. I also follow this practice when citing other primary texts of a literary or historical and historiographical nature. I refer in a note to the edition and then for the most part give specific citations parenthetically within the text. In some cases I also indicate the year of publication of a text in the parenthetical note in order to distinguish between the numerous early modern and late modern editions of the classical texts I have used.

All translations of Lohenstein are my own, as are all other translations unless specifically noted. I have followed the convention of citing texts in the original language first, followed by an English translation, except in cases when the syntax of the original would be confusing in the context. In these cases, I cite the English first, followed by the original text. Including both foreign-language original citations and English translations may seem to lengthen the text unduly, even clutter an individual page in some cases. In so doing, my intention is, first, to make all of the texts, but especially Lohenstein, available to as broad a readership as possible. Part of the point of this book is after all to introduce the texts of eastern central Europe into discussions of Renaissance and early modern culture in Europe outside of German departments. To do so, one must accept-even as one ponders the implications of--the linguistic barriers that have kept such discussions from taking place before. Second, citing the texts Lohenstein cites in both the original and in translation recreates in late-twentieth-century form a version of the early modern polyglossic universe in which he and his plays originally moved; experiencing this universe, if only in indirect form, offers an alternative to the anachronism of studying the early modern period in discrete "bundles" of national literary traditions rather than in a more comparative way. 

The Intervention of Philology 



\section{Introduction. Gender, Knowledge, Philology: The Case of Daniel Casper von Lohenstein}

\section{Lohenstein at the Crossroads: Early Modern Studies and the Politics of Location}

Eve Sedgwick begins her Epistemology of the Closet axiomatically. I begin here in a similar fashion, since some of the issues addressed in this introductory chapter may seem to take the reader somewhat far afield from this study's primary subject, namely the work of philology in the production of early modern gender identity in the Roman plays of the early modern German playwright, Daniel Casper von Lohenstein (163583). Like Sedgwick's axioms, my propositions here address the "groundings" of this subject both within its own matter and as a result of its location in a late-twentieth-century critical world. ${ }^{1}$ Designed to serve as connective conceptual arteries between the postmodern theory and the historical subject matter of this book, they signal the coordinates of its situation as a discussion of seventeenth-century, German-language texts informed by a number of late-twentieth-century academic debates about gender, method, and the geography of the disciplines.

The guiding principles of my analyses may be formulated in the following way: (1) things both are and are not what they seem; and (2) what you see depends on where you stand, what you look at, and when you look. At stake here is the relationship between our objects of study and the methods with which we study them; these relations determine the material, ideological, historical, historiographical, aesthetic, and epistemological categories of all knowledge-producing projects and claims. ${ }^{2}$ My two statements depend on one another in dialectical fashion; what appears to be the case from one historically specific, methodological and theoretical position or analytical and even literal location will appear otherwise if the position, moment, and method of critical "spectating" are changed. It is the project of this book to produce such a change in our understanding of gender ideology in the early modern period in Europe precisely by approaching a specific set of texts from disciplinary, theoretical, geographical, chronological, and methodological standpoints, or points of view, that have not been considered compatible with those 


\section{Introduction}

texts to date. In the process, new knowledge about the relation between gender and history, history and textuality, and textuality and gender will emerge.

The specific and separate communities to which such a project might speak - scholars of early modern Europe and its dramatic and historiographical traditions, as well as historians of early modern schooling, students of the history of sexuality and gender, postmodern theorists of gender, textuality, and performance, Germanists, and those interested in the tools and products of philological text work-will each find some familiar landmarks in the heterogeneous discursive economies and landscapes of this book; other parts of its matter and method will be new. The critical and substantive polyglossia of the readings may cause different kinds of interpretive static for different readers; after all, previously discrete disciplinary languages and cultures are asked to cohabit here. Yet, these difficulties are as intentional as they were unavoidable. My project has matured during a period when the postmodern reorganization of knowledge systems has become so conventional as to itself represent a new orthodoxy. Moreover, it has developed during a time that may come to be known as the post-Cold War era, when the very act of writing for a scholarly audience in the Anglo-American West about a series of dramatic texts originally written in the middle to late seventeenth century in areas that now belong for the most part to Poland must function as a provocation of sorts, in that it calls attention to both the literal and the figurative shifting of borders and boundaries in numerous ways. What happens to the concept of "Europe," for example, when we look at the end of the twentieth century to the cultures of what is now east central Europe, cultures obscured by Cold War rhetoric and realities from western scholarly vision for the past fifty years or more? Indeed, what image of the early modern "origins of the West" do we get when we displace our perspective from Italy and England in that period, for example, to territories still "European" but, from a modern perspective at least, decidedly east? These are obvious questions, as one colleague has put it, to anyone in the United States who has been involved in the study of any European cultural tradition other than the AngloAmerican one over the past number of years. They need to be confronted by all scholars of early modern Europe, however, as we try to make sense of the altered disciplinary environment and geography of the latetwentieth-century U.S. academy, in which the very study of Europe at all has itself come under attack.

The traditional "idea of the Renaissance," for example, and its central issues, genres, and figures have been crafted, with some few exceptions, 
out of primarily Italian, English, and occasionally French and Spanish sources for some one hundred years or more. ${ }^{3}$ The study of the cultures of central and eastern Europe during the early modern period has been left primarily to specialists during this time, and there has been comparatively little cross-fertilization between the discrete fields. Yet, at least one of the most influential scholars of the period, namely Jacob Burckhardt, who set the tone for Italocentric Renaissance studies, was not only himself heavily implicated in the fraught ideological and political debates over the status of the nation and its relation precisely to the states of central Europe in particular in the late nineteenth century, but was well aware of the fact that, as focused as he may himself have been on "the Renaissance" in Italy, the issues that were central to the period crossed multiple borders to both the north and the east. ${ }^{4}$ Subsequent accounts of the Renaissance by Cassirer, Warburg, Saxl, and Kristeller (accounts underread in the late twentieth century for the geographies of knowledge with which they work) actually portray the period in a similarly complex fashion, caught as much in their authors' own varying and historically specific projects of self-location and selforientation in a greater central Europe torn apart by the upheavals of World War I and World War II as in the matter of a more heterogeneous sixteenth- and seventeenth-century Europe that included not only English- and Romance-language areas, but extended into the polyglossic eastern and northern territories of both the Holy Roman Empire and other early modern states as well. What would happen, then, to the latetwentieth-century map of early modern studies in the United States in particular if we were to challenge its borders by introducing the complex cultures of central and eastern central Europe in the sixteenth and seventeenth centuries into the picture? How would its "central questions" and recent scholarship's answers to them change if we were to redraw the disciplinary map? The potential focus within any future early modern studies on "new" (newly visible, newly accessible) central European texts like those with which this book is concerned was made materially possible by the Wende, the "turn" that occurred in eastern Europe at the end of the 1980s and beginning of the 1990s, and by the reconfiguration of power and knowledge and corresponding redefinitions of margins and centers that resulted from the dissolution of the "Iron Curtain." Orienting ourselves in these materials as well as in the aesthetic, ideological, and historical issues that concerned a larger and more diverse early modern occidental world may take some time. Yet, the methodologies, chronologies, and disciplinary routines directly impacted by geopolitical developments both before and since 1945, including the 


\section{Introduction}

organization of literary studies in such a way as to include the study of only a select subset of western European nation-states, must and will give way to the new points of view constructed by a post-1989 world. ${ }^{5}$

The notion of a new point of view originating in central and eastern central Europe intersects with the rhetoric of spectatorship with which I began, for we now have access to and can see a different early modern period than the one previously considered as practically coterminous with the borders of what was until recently a primarily western European Community. ${ }^{6}$ Recognizing this difference is crucial to my specific object of study, namely Daniel Casper von Lohenstein's dramatic corpus, and specifically to those of his plays that stage scenes of political intrigue from a classical Roman past. Lohenstein was one of the major literary figures of German-speaking central Europe in the early modern period. He lived and wrote his plays in Silesian Breslau, now Wroclaw, Poland. His intellectual world was populated by both learned tomes hailing from a more familiar Renaissance and early modern tradition in Italy, Holland, and France and by a (to us) somewhat less well known set of seventeenth-century documents testifying to contemporary literary, political, and scientific developments in central Europe as well as in Silesia itself. Lohenstein's was a heterogeneous citational community, then. Seeing his plays both in dialogue with the textual culture of this world and as a series of literal productions of grand dimensions even for the early modern stage becomes possible if we look at them through the multiple lenses of postmodern gender theory, early modern historiography and political theory, the practice of learned annotation and publication, and the history of institutions of schooling as well as of the complex realities of local and imperial authority in central Europe at the time. Gender and power and how they are produced in a dynamic of both literal and textual concealment and revelation were crucial to Lohenstein's texts when they were written and staged. Yet only passing attention has been paid to these dimensions of his work by scholars of the German Baroque; critics involved in the exciting debates about the politics of gender and drama in the early modern period, especially in England, over the past fifteen years have been similarly oblivious to the ways in which central European documents like Lohenstein's plays might impact their claims. Producing a new visibility for his (in more ways than one) obscure texts by means of historical-philological study and gender critique is thus the project of this book. ${ }^{7}$

Lohenstein's plays are monuments to the highly learned, highly politicized, and yet, finally, also highly conventional school culture of the early modern period that explicitly addressed issues of gender, power, and political subjecthood in terms of their relationship to the legacies of 
the classical past. They did so, moreover, by using cross-dressed adolescent schoolboy actors to stage exotic, often lascivious scenes of political intrigue, seduction, torture, and murder derived from contemporary editions of ancient texts. In their local conditions of textual and stage production and reception, Lohenstein's dramas thus provide a window onto what appears to be a very bizarre version of the early modern period, a version that nevertheless can be read as not so very anomalous once considered against the background of the textual and material cultures out of which it emerged. Indeed, his plays were produced by an academic culture in some respects not unlike our own, training grounds, even factories, both for the production of workers for a variety of early modern and late twentieth-century professions. Seeing them in the light of the schoolboys' gradual professionalization and asking ourselves just how much the plays complied with and how much they resisted the literal and ideological tasks of the schools allows us to reflect on both their and our own investments in a variety of historical, theoretical, methodological, and institutional debates as we attend to the business of studying the learned cultures of earlier periods in a postmodern world.

The fit I am describing between Lohenstein's plays and the late twentieth century may appear somewhat uncanny. Yet, if N. Katherine Hayles is correct, all texts are "permeable membranes through which flow the currents of history, language, and culture," both historical and our own. ${ }^{8}$ As we register the specifics that make these peculiar German plays so intriguing as local historical artifacts, we can "listen in on" a variety of messages about gender, knowledge, and power embedded in them: their origins in a very specific and complex political culture on the eastern frontiers of the West, for example, their explicit interest in and devotion to both displaying and dissecting the origins of sexually extravagant behavior, their bloated learnedness, finally, and polyhistorical intertextual nature, which dictated that whatever encounter with cultural diversity, confessional-political contentiousness, or learned controversy that marked the early modern period and was inventoried in books would be noted, explored, and cataloged within the boundaries of the texts themselves. The questions that can be posed about these issues as they become visible within the historical text work of Lohenstein's plays also resonate with contemporary readers, and will do so whenever we consider difficult artifacts from this or any other earlier period that lies so very close to the literal, ideological, and textual origins of the "civilized" western self.

These particular artifacts, Lohenstein's four Roman plays, of course also stylize themselves as reviving these origins precisely in their representation of classical scenes. How are we to reconcile the reputed 


\section{Introduction}

otherness of a corpus of texts as peculiar as Lohenstein's, which have so often been taken for artifacts of the bizarre, with their simultaneous indebtedness to traditional materials and rhetorical and historiographical techniques and concerns? Indeed, how will the landscape of what we have taken to be the "traditional" mechanisms of knowledge transmission and institutions of schooling among "our" learned ancestors change if phenomena like Lohenstein's plays become visible precisely as conventional for at least one version of the period's fascination with reviving the past? My intention in posing such questions is not to exploit what some might maintain is the "marginal" field of German Baroque literature by making a subset of what are admittedly some of its more extreme textual products into exponents of political textuality or queer hybridity, of postmodern gender theory or deconstructive historiography avant la lettre. ${ }^{9}$ Rather, my project concerns the methods (including my own) by which what John Guillory has called "cultural capital" is and can be (re)created and transmitted, specifically in early modern European studies, and the impact that these methods have upon our image of ourselves as it is indebted to this particular textual past. ${ }^{10}$

The focus of my initial axioms on seeming and being, on the implications of visibility for both knowing about and reading historical artifacts and for theoretical reflection, may appear either pedestrian or naive in an academic discussion conducted in post-Heisenbergian discursive time. The "story of how and why positivism failed" is a familiar one, as Hayles notes. We have known for some time that how we know something directly impacts what it is that we know, and thus that there can be no inert objects of knowledge apart from the knowledge that produces them; "observations are always shaped by preexisting assumptions," she writes. ${ }^{11}$ What we see depends on where we stand and how we look. Yet, considering the early modern period and the materiality of its texts as themselves articulating this self-consciousness has occurred in only a limited number of studies to date.

Lohenstein's Roman plays are self-conscious in just this way; they both are and are not what they seem on first sight-namely, conventional, yet outrageous; soporific, yet scandalous; marginal, yet central to understanding some of the underlying concepts of learnedness, power, and gender in a very specific corner of the early modern European world. They seem to play with the tensions between these oppositions in a variety of intentional ways. Enormously dense, for example, monumentally lengthy and learned and as a result, one would imagine, hardly performable plays about the incestuous political and erotic intrigues of classical Rome, these texts were written in German in the middle to late seventeenth century by a prominent city administrator with important 
connections to his own municipality as well as to both local courts and the Empire. They were published in elaborately annotated editions, yet also staged in the houses of local sponsors between 1661 and 1669.12 While focusing inevitably on female personalities as their title figures and dramatic protagonists, finally, they employed adolescent schoolboys from local Protestant schools to play all the roles and to enact even the most licentious of the scenes between women and men. From what point of view, then, should we consider these plays as evidence of early modern culture or late humanist learning? As outrageous exceptions to or as typical of early modern institutions of learnedness and learning and their relationship to the public sphere? It is difficult to tell what Lohenstein might have intended--perhaps both. To what degree, moreover, were these transvestite performances in concert or at odds with the charge to the schools of the time to educate the future (male) workers of the early modern administrative-bureaucratic class for the Empire, the cities, or the smaller principalities of eastern Europe and their surrounding dominions, or with the claims of recent scholars of schooling about the role of the "educational system" in the "ideological training" and production of "the male civil subject"? ${ }^{13}$ Perhaps they were affirmative and subversive of a variety of pedagogical and political imperatives at one and the same time. Were, finally, the gender ideologies being examined in the plays consonant with or opposed to dominant codes, either of the period in general or of the particular context in which they were produced? How did boys, women, and girls receive the messages that the plays were clearly designed to convey? How one (re)tells the history of "early modern gender ideology," or of "late humanist drama," or of "early modern political culture" and "Renaissance schooling" depends, then, on how one perceives these plays. How one answers these questions depends on where one stands.

The most intriguing aspect of Lohenstein's plays is, then, that the question of how to consider issues of learnedness, schooling, politics, and gender in terms of a mobile economy of being and seeming is posed not just by the postmodern scholar of early modern material and ideological formations, but also-and perhaps just as important--by these late humanist texts themselves. "Material forms" produce "effects of meaning," as historian of the book Roger Chartier has argued; "technical, visual, and physical devices ... organize the reading of writing when writing becomes a book." ${ }^{14}$ That is, although Lohenstein's dramatic texts have seldom been read as play scripts, it may seem obvious that dramaturgical issues should take a front seat once one considers the question of their staging, particularly in the context of the close attention paid in English Renaissance studies to the status of boy actors in the 
production of many Elizabethan plays..$^{15}$ Yet the gender-bending scenarios and political-ideological struggles central to the plays are also apparent in ways associated more with their status as print objects than with their production. Based on multiple sources, including ancient historiography and literature, as well as on contemporary political theory, geographical description, and collections of illustrations of arcane monuments and artifacts, old and new, the plays present themselves as opaque textual objects that nevertheless obsessively attempt to clarify themselves by cataloging their complex provenance in exquisite and teeming detail in the elaborate notes (Anmerckungen) published along with them. As fascinating as Lohenstein's plays are, then, as documents of a fantastically extravagant, yet also apparently more or less legitimate stage culture, their significance for our understanding of the complexities of gender ideology that also informed learned culture and print objects cannot be ignored.

The notes to Lohenstein's plays often run from a fourth to a third of the length of the "main" text, an average of some thirty pages of closely printed annotations for plays ninety to one hundred pages in length. The apparatus calls attention, of course, to the fact that the very attempt to capture the classical Roman past, to manage and constrain its meaning in print, also enables and, indeed, is predicated upon its constant disruption and reformulation. The swollen, often confusing and heterodox learnedness of Lohenstein's notes makes it difficult for their several audiences, both historical and ourselves, to pin down "what the plays are about" even though we and they appear to be given so very much information with which to do so. The difficulty of establishing any single "meaning" for and about such textual acts is represented in turn precisely in the mobile relationship between Lohenstein's play texts and their notes. Both of these complex relationships will be explored in depth in the chapters that follow. The question of the political and ideological intentions and significance of texts driven by what theorists of the hypertext have more recently called "axial organization" is thus not imposed on them by the postmodern scholar but is, rather, raised by the early modern texts themselves, in which "references, variant readings, and other supplements to the main text radiate from [them]" in such a way as to defy any principle of a single message or stance. ${ }^{16}$ The learned cacophony of Lohenstein's plays as print artifacts can prove something of a barrier for both casual readers (if any exist) as well as for critics who would seek to stabilize any particular reading--historical, philological, typological - of them. Yet the plays are committed to documenting the mobility and complexity of early modern information and meaning systems that were simultaneously material and formal, political, ideologi- 
cal, and institutional as well as aesthetic, philosophical, and doctrinal, traditional and unorthodox, all at once; we cannot read them at all if we do not recognize and accept these commitments. As much as some might argue that the age of books swore allegiance to the fixedness of meaning and used print technology to secure it, it is clear from textual phenomena such as these plays that books set knowledge in motion as much as they attempted to "order" the world of the written word by capturing it in print. ${ }^{17}$ When we tell history, the history of gender on the early modern stage or of the "origins" of early modern political culture, then, the same principles of (dis)order that inhere in the materiality of texts such as Lohenstein's must inform our narratives about these issues as well.

To some, the hybridity of a study of Lohenstein and the learned culture of early modern central Europe that positions itself within contemporary debates about postmodern literary and gender theory but also relies on a philological approach that might appear conservative and old hat may thus seem incongruous, even strained. Yet, as I have indicated, this methodological hybridity is deliberate. Not only is it appropriate to its objects of study, but the new knowledges that it produces are designed to disestablish disciplinary boundaries and practices among a variety of communities of theorists, literary historians, and philological text workers in such a way as to make new dimensions of the early modern more visible than has previously been the case. The material conditions of knowledge production in our time-as in Lohenstein's - dictate and create the possibility that heterogeneous texts, the texts of postmodern theory and the texts of literary history, for example, become so intertwined and inseparable that movement on one front necessarily creates movement on another, producing what, after Donna Haraway, we might call cyborgenic textual states. ${ }^{18}$ Indeed, because we increasingly inhabit a world defined by its institutional and historical status, what Mary Louise Pratt calls a "contact zone," 19 either our own (faculty) participation in several of these (or other) worlds or by means of the contaminations that our students effect as they move from (early modern literature) classroom to (theory and gender studies) classroom and back again, the insights and cultures of both sites invade, antagonize, and occupy, or endorse, supplement and protect each other, or, more often, do some combination of all of the above. Some would call this state of contemporary text study arbitrary or chaotic. Again, it is Hayles who suggests, to the contrary, that we revalue the lived realities of our complex institutional lives, "characterized by multiple strata and marked by innumerable fissures," as productive of nonlinear constellations and narratives of knowledge, turbulent and unpredictable, but 
never inert. ${ }^{20}$ If, as feminist theorist Katie King has claimed, knowledge can and does inevitably travel in and out of a variety of institutional, material, methodological, and political time frames and contexts, shedding and growing new identities both for itself and for its practitioners in each version, so too can and do individual events of past literary histories open themselves up as theoretical interventions and articulations to those who can hear. ${ }^{21}$

Finally, in taking a very specific set of learned texts of the early modern period as my main object of study and allowing them to both illuminate and be illuminated by questions about gender, textuality, and power, I seek to trouble the chronology of the dominant theoretical paradigm of the late twentieth century that considers the recognition of the importance of local knowledges, "petits récits," and mobile identities only as an effect of postmodern self-consciousness, as if such a presentist logic were "in fact" the motor behind the emergence of this or any other theoretical position. The creation of (in)visibility for the past by means of "asymmetric" narratives about its relationship to the present, accounts that would describe a "before" of either simplicity or error and a "now" of either sophisticated complexity or superior clarification of knowledge, has produced a story about centers and margins, "fundamental" and discardable knowledge, and pre- and postmodern theoretical positions and epistemologies that is now in need of revision. ${ }^{22}$ My point is not, however, to assert that early modern central Europe was "always already" postmodern, or that "they" (the early moderns) already knew what "we" moderns have just stumbled upon, or even that the phenomenon of electronic hypertextuality is no more than warmed-up humanist commentary (although there are many similarities in its deployment indeed). Rather, the obsessive concern with contemporary culture that characterizes so many recent theories of decentered meaning has produced the collapse of the history of western literary-textual and cultural production into a caricature of itself against which opponents now tilt full-force, as they feel they must in the interest of complicating the picture. ${ }^{23}$ Presentism of this sort leads, I would argue, to a reduction of the available terms with which to think our way out of and beyond the very essences and monoliths, such as "the Enlightenment subject" and "scientific rationality," that have now been under attack for a good decade or so. ${ }^{24}$ The interruption of presentist narratives about past systems of learnedness and politics and about gender identity and about the relation of gender to power in the early modern period is thus a further metacritical task of this book. The texts that I reread in it nevertheless also themselves act as splendid allegories of and are even "isomorphic with" this disruptive method. ${ }^{25}$ Thus, the- 
ory, literary history, and close readings accompany and sometimes even replicate one another throughout.

\section{Philology and the Construction of Early Modern Gender Identity}

Rearranging some of the dominant chronologies and geographies of contemporary theory and European literary studies to reconsider the complexity of gender identity, political subject formation, and the relationship of learning and power in Lohenstein's plays calls attention to the question of method in another way too. It foregrounds the question of the accessibility of these particular early modern texts and others like them to the postmodern world. The complex and densely learned nature of the plays can inhibit more pleasure than it produces on the part of modern readers; it is simply too difficult to understand what they are about in any number of ways. Implicit in the issue of producing a new visibility or point of view addressed in my initial "theoretical" reflections is thus also my own desire to (re)introduce the kind of philological text work necessary for reading Lohenstein's plays in the first place as a possible method into contemporary debates about the construction of historical gender systems, debates that have seldom involved this kind of learned approach to the past. ${ }^{26}$ Both my own readings and Lohenstein's philological efforts engage in this enterprise, in the production of new knowledge, that is, about the mobility of gender identity in his Roman plays, in texts that might arguably be considered some of the most pedantic of the early modern period even as they outperform their contemporaries in terms of outright extravagances and lasciviousness of many kinds. The combination itself is worth contemplating as a perplexing coincidence. An early editor of one of the plays, Conrad Müller, writing in 1882, in fact condemned Lohenstein's juxtaposition of erudition and the erotic. Yet, in so doing, Müller also underscored their inseparability in the performance of learnedness in the playwright's oeuvre; "Seine Muse ist eine kalte, berechnende Dirne, geschminkt mit Gelehrsamkeit, und es ziert sie nicht, daß sie ihre unförmlichen Reize buhlerisch aufdringt" ([Lohenstein's] muse is a ruthless, scheming whore; her makeup is erudition, and it does not become her when she forces herself [upon one] in amorous fashion with her inelegant allures). ${ }^{27}$ Both editorial and interpretive approaches to Lohenstein have stumbled repeatedly over the coincidence of indecency and scholarliness in his dramatic works, and have struggled, at least since Müller, if not also before, to negotiate the slippery terrain that lies between mak- 


\section{Introduction}

ing the learnedness and the licentiousness of his plays visible in ways that complement one another.

I seek to engage, indeed, even to exploit this particular conflation in Lohenstein's texts rather than to deny it. Many twentieth-century readings of the plays, for example, have turned a blind eye to the connection between erudition and excess that these wanton philological objects express. They do so either by hiding the plays themselves almost entirely behind pictures of "meanings" rooted in economies of either national or, more recently, local Silesian Geist, ${ }^{28}$ or by masking their extravagances entirely by means of decorous commentary on the ways in which Lohenstein's work articulates the consolidation of a particular class ideology in the early modern state at a certain time and place. ${ }^{29} \mathrm{Re}-$ cuperating his texts not as simple mirrors but, rather, as confusing and seductive objects, whose textual, sexual, and political complexities can in fact never be treated as distinct from each other is the work that philology can do. That is, philology - both my own appeal to it and its centrality for the author, producers, and historical recipients of these plays - can render visible and function as an instrument for tracking the production of multilayered and mobile meaning systems in the early modern period, when traditional forms of learnedness were not at odds with questions of gender identity, political agency, and sexual power. It can also serve to make texts from central Europe present in scholarly discussions about the early modern period that for the most part have listed curiously westward for far too long. ${ }^{30}$

With the notable exception of work by Stephanie Jed, recent debates about early modern sex-gender systems and their relationship to political ideologies have for the most part failed to consider philological and textual practices either as tools of gender analysis or as partners in historical, theoretical, and critical ideological research. ${ }^{31}$ In so doing, they have succumbed to the division of literary labor that Katie King notes has become standard within the academy today, with "workers in the construction of texts" existing in separate, often subspecialized locations from "workers in the interpretation of texts." ${ }^{32}$ Nevertheless, philology in particular, with its traditional definition, according to Roman Jakobson, as "the art of reading slowly," ${ }^{33}$ not only releases the pleasures of the text, but enables a denaturalization of the written record of traditional categories of literary and historical "evidence" in general and of the significance of gender in particular. "Slow reading" makes visible, in other words, the mechanisms by which ultimately irreducible, multiple, complex, and competing formations and versions of power, value, and meaning are strategically selected, simplified, and reduced into apparently simple stories and texts concerned with the construc- 
tion of hierarchy, value, and "progress." It is not by chance that the four plays that I analyze have as their subject events from the history of classical Rome. Both early modern antiquarian knowledge projects about antiquity and contemporary editions of classical authors were themselves structured, like Lohenstein's texts, in ways reminiscent of Freud's image of the archaeological multidimensionality of that city as a model of the human psyche, with traces of various historical periods and heterogeneous moments and architectural styles constantly competing in disjointed and jumbled fashion for recognition within the unitary space of the latter-day tourist's eye. ${ }^{34}$ Philology reveals the seductiveness of Lohenstein's Roman plays in just this respect; it draws the reader and audience ineluctably into the complexities and confusions of their multiple historical and discursive sedimentations. Reading the interstices of these layers produces not only pleasure but also a more fraught image of gender identity and political subjecthood than we have been taught to expect.

Feminist classicist Page DuBois has written that "[o]ne of the impulses of philology has been to attack the problem of the fragment directly." 35 As conventionally understood and, indeed, frequently professionally practiced, DuBois continues, philology has been invested in projects of restoration, of "imagin[ing] ... the missing parts" and "repair[ing] what was transmitted inaccurately" such that "integrities" of both contexts and texts emerge out of partialities. Such investments appear in decided contrast to the "disintegrative" project of philology I have described here, and it is in opposition to this image of a restorative, integrationist, and implicitly totalizing craft that critiques of philology, such as those by Jonathan Culler, for example, have been addressed. Culler is dismissive of what he characterizes as standard philology; he calls instead for an "anti-foundational philology" that would understand itself as also implicated in constructive, interpretive work, rather than as "basic" or as a foundational "kind of first knowledge." 36 His argument replicates William Arrowsmith's condemnation of Wilamowitz's rejection of Nietzsche's philology in The Birth of Tragedy, which, as Barbara Johnson has pointed out, assumes that philologists (here Wilamowitz) are nothing but crude "technician[s]" (so Arrowsmith) whose desire for exactitude necessarily implicates them in totalizing knowledge projects, the fissures of which then become invisible behind a facade of alleged "facts." 37

Culler's rendering of a merely "mechanical," unselfconsciously scientistic philology, committed only to the production of "truths" and unaware of its own "ideological dimensions" and historical investments, ${ }^{38}$ is certainly partly an interested cartoon that flattens out the immensely 
complex history of philology in order to produce a "progressive" methodological narrative about those of "us" who work "beyond philology" by producing self-conscious and creative interpretive "readings" eschewed by the "pedants." 39 At the same time, his caricature of an antiseptic philology with no agenda at all must also certainly be understood as a reflection back to philologists of all stripes of the glaringly obvious historiconationalist agendas and rhetorical registers that have infected their claims of being engaged only in "objective" knowledge projects and thus beyond "local" theoretical or "political" debates..$^{40}$ The slim publication in which both Culler's and Johnson's remarks can be found contains the proceedings of a conference on philology in 1988 that speaks volumes about the reification of both of these positions in the late twentieth century in the United States.

DuBois's own work on the texts of archaic and classical Greece nevertheless points to the reality, both in the United States and, notably, in France, of the multiple other potential versions of a not necessarily "Anglo-Teutonic empiricis[t]" philology, which would serve the ends of what she calls a "historical material historicism." 41 The potential for a "social studies" or political history of philology capable of tracking the ideological and political embeddedness of all philological engagements, including DuBois's own, is on the rise in studies of the disciplinary origins of classical studies. Philology's allegedly disinterested (but always ideologically driven and contestatory) disinterment and deciphering of past data, seeking sometimes to embed it in a master narrative, sometimes to "break it up even further, into more manageable entities," has nevertheless often provided unmistakable, if often unselfconscious evidence of the partisan localness of its claims in the past. ${ }^{42}$ The apparently neutral work of text editing is a case in point; I return to the most appropriate example of the partisan nature of editorial work in the present context, namely Klaus Günther Just's Cold War edition of Lohenstein's plays, in the conclusion.

The implication of philological work in all reading and interpretation, traditionalist and heterodox alike, is thus important to remember. All "readings" are based on specific and ideologically colored editions of texts. Locating the practice of text editing as well as the disciplines of textual criticism and bibliography, for example, on the periphery of "literary studies," where it and they are justified only "by the uses to which their results are put," accepts a reductive image of these and other kinds of text work that are in fact not preliminary but rather intrinsic to and themselves part of "literary study" writ large. ${ }^{43}$ Textual criticism has been complexly theorized in the work of Jerome McGann and of D. C. Greetham, among others; in fact, philologists and editors have 
known for quite some time what their alleged "drudge" work has taught them, namely, that texts are "always already" materially and historically unstable, "radically hospitable to ... intervention," 44 and, as such, as classicist James Zetzel has shown, "unprotected" whenever they become the objects of subsequent ideological projects. ${ }^{45}$ Although there has of course been and continues to be text-editing work that claims the ability to reach back into and discern the past with scientific precision, philology is not intrinsically implicated in a narrative of progressive teleology, whereby we will someday attain to, occupy, and own a flawless picture of the difference of the past or the meaning of a text. Rather, philology makes visible precisely the historical depths and unstable borders of all texts, including those concerned with issues of gender. ${ }^{46}$

This is a big claim, and to indicate its origins, I must back up somewhat. Philology's identity even at its ancient western origins as the site of the production of nearly illegibly dense texts - its historical implication, that is, in the creation of language products as multiply layered and impossibly "thick" - has been elegantly described by Anthony Grafton, among others. According to Grafton, practicing philologists like the great late-eighteenth-century classicist Friedrich August Wolf, and also many before him, knew that there could be no access to the stable, "original texts" of Homer or Hesiod, for example. This was so not only because archaic poets never wrote their poetry down, but also because the multiple layers of subsequent Hellenistic editorial intervention, recension, and reconstruction revealed that the pious reproduction of texts wie [sie] eigentlich gewesen had never really been the primary project even in the work of the Alexandrine scribes who created the only extant manuscripts to which historical philologists like Wolf and others had access and on which they based their own work. ${ }^{47}$ Thus historical philology was practiced by text workers who already knew, in both the Wolfian, protohistoricist era and earlier in the sixteenth century, not only that that world was itself a densely organized and often confusing one, but that their windows onto it were themselves at best complex "conglomerates," "messy" witnesses whose corruptions and contradictions could be mapped by historians of scholarship, but never "clarified" or removed by textual scholars, try as they might. ${ }^{48}$ Jed offers an intriguing reading of the gendered and engendering work of Florentine philology in the fifteenth century that sought to transform the "text site" of encounters with the Ancients into the crucible for republican political identity by "castigating," rendering chaste, accurate, and pure the texts of Roman history "sullied" by editors during the intervening years. ${ }^{49}$ Nevertheless, the knowledge that their own immediate philological efforts could do nothing more than create further "contaminations" even 
as they sought to transmit "untouched" ancient texts, created countless anxieties about whether those who would be correctores would not necessarily also be corruptores. In their histories and analyses of textual criticism of the classics in the Renaissance, Silvia Rizzo and E. J. Kenney have also distinguished between theories of philological emendation that sought purity of various kinds, and their practice, which as often as not created additional dislocations even as they perpetuated past errors in allegedly rigorously produced texts. ${ }^{50}$ Thus, philologists may have claimed to want to render the texts of the Ancients newly accessible, close to their "origins," and pristine. But they produced, and knew they were producing, uncertain and confused texts that testified more to the ingenuity of their editors than to any "original" state.

In its early modern iteration, then, philology produced texts that could not be characterized as unambiguously stable or pure. To the contrary, what their apparatus more commonly lay bare were the untidy processes by which texts were constructed and reconstructed at various historically, culturally, and institutionally specific and partisan places and times. Gaps, fissures, residuals, emendations, supplementations, and transfigurations were visible to all in these heavily annotated texts. Later interest in using the tools of philology to get at the density and "thickness" of artifacts and objects of knowledge and at the place of text work (editing, printing, collecting, circulating) in them ranges from Saussure's admission that it was the "almost ethnographic side" of language itself, the fact that it belongs "to a certain people having certain origins," that allowed it to "keep its interest" for him, ${ }^{51}$ to anthropologist Clifford Geertz's formulation a hundred years later of the need for a "new philology" to be deployed by anthropologists. Geertz calls for the creation of a "blurred" critical-methodological "genre" using the textualist's understanding of the complexities of meaning production to engage in multivectored "reading" projects of a sociological-ethnographic kind. ${ }^{52}$ Guillory's description of the place of his philological narrative about the development of a "history of the social relations of writing" suggests the intersection of the textualist's and the materialist's interests and concerns in a similar way. ${ }^{53}$

In this philology many postmodern textual theorists will recognize the work in which they "always already" engage, work that looks for and finds registered in textual form the often (and perhaps necessarily) incomplete struggles for ideological hegemony and self-articulation, inter- and intranational linguistic travesties and parodies, and complex textual "hybrids" and "interanimation[s]" of all manner of discourses that characterize each and every historically specific language site..$^{54}$ This philology is also, as Carlo Ginzburg has suggested, truer than has 
been thought even to the lineage of post-Wolfian, "second-wave" philology in the nineteenth century, whose location at the originary moment of the little illuminated paradigm of "conjectural science" allowed it to accept the fundamental opacity of "reality" and to take instead as its task the production of knowledge out of seemingly insignificant clues, traces, and details. ${ }^{55}$ Geertz and Ginzburg believe, perhaps just as much as their early modern predecessors, in the possibility of a differently organized philological knowledge that proceeds via conjecture and analogy indirectly to "deeper realit[ies]." 56 But the very nature of the evidentiary protocol for which Ginzburg in particular calls, with its dense construction of single, local objects of knowledge, makes the assumption of ever being able to arrive at anything other than these constructions, as illuminating as they might be, counterintuitive. Both in these more contemporary versions and in its more historical meaning, then, as a "science composée" (hybrid science), ${ }^{57}$ philology registers and allows for the composition, or construction, of knowledge-both of itself and of the object of study - as multiple and mediated, as partial and anomalous, variable and mobile, productive not of "resolution" but only of "more knowledge and more, not fewer, choices." ${ }^{58}$ Here the parallels between philology and postmodern hypertextual logic emerge.

My desire to make visible the density of philologically organized knowledge projects about the construction of gender identity in the early modern period thus underlies my analyses of Lohenstein's four German-language school plays about Rome. These texts are fundamentally nonunitary in a variety of ways. Written by one of the period's most well known playwrights, who was also a member of the learned intelligentsia and a major figure in the local governmental apparatus in the important Silesian city of Breslau, the plays were based in large part on reworking scenarios from ancient Roman domestic and foreign history. They used editions of some of the classics of Roman and foreign history available at the time as prominent, although not exclusive, sources. As such, the plays could and have been taken as themselves instances of "foundationalist" philology, symptoms of the desire of the period to (re)create itself unproblematically as a transparent image of the Holy Roman Empire's past in classical times by reviving not only that past's texts but those texts' past as well. While Lohenstein's enactment of this script of revival is not widely known in the late-twentieth-century academic world beyond a small circle of specialists, except perhaps to those familiar with Walter Benjamin's treatment of German Baroque drama, in which philology also played a central role (see my conclusion), the scenario itself is a familiar one, performed across early modern Europe with magnificent consistency in a wide range of genres; in England, 
France, Italy, and Spain, as well as in the Low Countries, the reproduction of scenarios from Roman history allowed the ideological inscription of players and audiences, authors, patrons, and consumers, both on the side of the state apparatus and against it, into narratives of consolidation, opposition, and power. ${ }^{59}$ Particularly strong during this period and everywhere textually present in editions of classical historiography as well as in literature, then, reminiscences of Rome went on to haunt the eighteenth and nineteenth centuries, providing the outlines for political action and theory in both the Old World and the New. ${ }^{60}$

I return later to the tense nature of the claim that Lohenstein's plays worked in an unambiguous fashion to recall the Holy Roman Empire's classical forebears. Given the playwright's complex relationship to the Empire in his capacity as legal representative of Breslau to the Habsburg court, even a surface glance at the plots of his texts can discern an unequivocal celebration of such a direct inheritance only with difficulty.$^{61}$ For as much as two of Lohenstein's plays, dating originally from the 1660s, retell moments of Roman history that demonstrate the superiority of the "imperial" model in his so-called African plays about Rome's vanquishing of the Numidian queen, Sophonisbe, during the Second Punic War, or about Augustus's defeat of the powerful Egyptian queen, Cleopatra, in the first century B.C.E., his other two (more strictly speaking) Roman plays from the same period, about Epicharis, a freedwoman involved in the Pisonian conspiracy, and Agrippina, mother of the emperor, Nero, concentrate on the onset of the decline of the empire during the reign of that degenerate leader. The very splitness of the corpus of his plays about Rome thus prohibits a reading that would see them as unilaterally recuperating the past as part of a master narrative of imperial power in spite of Vienna's complex, but nevertheless real dominance over Breslau by 1675, if not before. The vexed relationship to contemporary historiography of Rome that is everywhere visible in the notes that accompanied the plays into print only underscores this disjunction. In a kind of centrifugal movement, then, Lohenstein's philological work of (self) commentary inserts the plays into and opens a door onto an immensely wide and seemingly endless contemporary textual world that itself contained not only multiple and often conflicting editions and versions of the ancient historical record, but also "soundings" of the complex, for us nearly inscrutable, and, in the widest sense of the word, multicultural political world of early modern Silesia, in which facile obedience to ancient Rome's early modern "double" in Vienna was not a political stance that could be assumed.

The cultivation of immense learnedness about both the Ancients and the Moderns, about nature and culture, about the obvious and the ob- 
scure, was, moreover, not just an idle pursuit in early modern central Europe, but was, rather, a professional location for men like Lohenstein. Like most of his learned contemporaries, he occupied not a marginal but rather a central position in both the civic and imperial political arena when he was writing and annotating his plays. ${ }^{62}$ As Syndikus, or city advocate for Breslau, Lohenstein had crucial responsibilities as an intermediary between the city and the Empire at the same time as he was also responsible for discipline in the city and overseeing the schools. His plays were thus public objects of knowledge that negotiated the dangerous waters of political advocacy each time their notes and sources revealed a favoring of one or the other Roman historian, many of whom were identified, as Peter Burke has shown, with clear political ideologies by this time. ${ }^{63}$ Each time the notes alerted their readers to the possibility of a contemporary parallel and thus revealed in their details not homogeneity and a totalizing narrative of "scientific" humanist knowledge about the Ancients, ${ }^{64}$ but, rather, a tolerance, even cultivation of textual, cultural, and ideological dissonance in early modern receptions of the past, philology enabled, even provoked, a contentious "conversation" between the "main" text and the notes, "territor[ies]" both "of contestation upon which issues of political, religious, social, and literary authority" and self-authorization were being "fought." 65 In this context, the distinction between Lohenstein's plays as scripts for public performance and as learned print products, as well as between the primary and supplementary textual locations of a "main text," on the one hand, that threatens to collapse under the weight of an "excessive" critical apparatus, on the other, becomes as difficult to maintain as the distinctions between politics, pedagogy, pedantry, and eros in the early modern world. Although the plays were for the most part originally produced in the homes of patrician and noble families of note in Breslau, and thus not in the schools themselves, the schoolboy actors certainly understood the performances and the world of texts to which the notes pointed to be a part of their lessons in political theory and survival technique, all of which constituted the realia of their education as well as of Lohenstein's professional world.

The very presence of an immense, learned apparatus thus signals the distance from and gap between Lohenstein's renderings of Roman history and the information contained in his sources, which themselves again, as physical objects of early modern text work, also underscored the inaccessibility of any simple or fixed past (see chapter 1 ). The plays' relationship to Rome was as "messy" as it was in the editions of ancient historiography on which they relied, many of which conflicted with one another in their recording of traditions and explanation of events, but 
all of which Lohenstein cites in deliberate detail. As texts, Lohenstein's dramas are thus as split and diversely positioned in relation to their own (textual) past as we, in our own postmodern location, are in relation to them. Lohenstein the philologist makes it impossible for his reader to overlook the vexed relation between his works and their sources; when "we philologists" read them, we reproduce these tensions as we negotiate multiple layers of textuality in much the same way as he himself must have worked in a world of complex and mobile texts. The plays thus demand what contemporary textual theory has called "radial reading," a nonlinear, disruptive encounter that oscillates back and forth between the historical "text itself" and the notes. ${ }^{66}$ In so doing, they draw attention to their own palimpsest-like movement back and forth between the multilayered and unstable character of the texts of history, historiae, stories in their multiple versions, that intervene in and interrupt history as the res gestae. ${ }^{67}$ Lohenstein's plays require us to engage in such readings whenever they point in their annotational apparatus to the ways in which they rely on partial and contingent historical knowledge projects themselves.

But where is gender in these scholarly displays and how did or can philological efforts intervene to construct it? Given the apparent yet perhaps also ironic pedantry of the texts, it should come as no surprise to recall that the plays, as scripts authored by a prominent political philologue, were produced by the young students at one of the two all-male Protestant Gymnasia in Breslau. Like many other of the period's major poets, Lohenstein had attended one of these schools; the productions of Roman plays were presumably designed to reinforce the boys' in-school lessons in rhetoric, history, and deportment, preparing them for a world organized at least institutionally along not dissimilar lines. The notes may have been designed to drive home these lessons in unwieldy, yet also incredibly rich and provocative detail, schooling the boys in the lessons of intrigue, negotiation, and, finally, violence, with which they, as future players on the stage of early modern political culture, would have to be familiar. Richard Halpern and Walter Ong have argued that the schools functioned as the factories of male political and social subjectivity; ${ }^{68}$ Lohenstein's plays cooperate in a complex way with this image of the educational apparatus as complicit in the production of the early modern state's administrative class as populated by men (see chapter 2). ${ }^{69}$

All the same, it cannot be overlooked that the protagonists of Lohenstein's plays about Rome were exclusively female and that the stories told about them were organized around the centrality of their interventions in republican and imperial events. This knowledge fractures the 
image of an exclusively homosocial politicopedagogical sphere to which I just alluded, in the same way that the extent and heterogeneity of the notes interrupt the progress of the stage action for any reader who holds one of these texts in her hands. There are in fact "women" everywhere in these plays performed by boys; the images we get of them often challenge what we thought we knew about these historical and legendary figures, many of whom had been the focus of numerous textual treatments in classical, early Christian, and medieval times. That the boy actors merely stood in for their (in the most radical sense) absent female "originals" is underscored by the fact that the plays are full of scenes that demanded both on-stage transvestism and the explicit eroticization of the acting body, thus calling attention to the gap between the boys' acting bodies and those of their characters in numerous ways. As often as not, however, this gap can be understood, if not closed, by descending into the cluttered "basements" of Lohenstein's notes where some of the "root-systems" of early modern gender ideology can be observed. ${ }^{70}$

Moreover, the issue of the presence of women in Lohenstein's plays becomes visible in the intersection between learning and the material conditions of their staging in another way too, for the boys were as involved in the production of a hybrid gender identity as were the female heads of state so crucial to dynastic and confessional stability in several of the smaller principalities of eastern central Europe in this period, women who sometimes served as Lohenstein's patrons as well. We read the plays somewhat differently, in ways, that is, that the boys and Lohenstein's women dedicatees and sponsors might have done when they engaged with his texts (see chapter 3), once we are aware of the realities of and reasons for female leadership in and around Breslau at the time. Visible in the plays' sources are surprisingly "modern" stances on the origins and value of female power; reading these traditions deeply and slowly reveals how the boys playing powerful women may well have been "bodying forth" contemporary political truths in Silesia in transvestite form. The challenges that the history of these female heads of state offered both at the time and to scholars of early modern gender systems are neatly captured in the image of boys playing women in performances dedicated to women playing politically male parts.

Both as scripts and as printed texts, then, Lohenstein's texts register the material and ideological complexities of producing history, male and female political identity, and learned plays in early modern central Europe. In the chapters that follow, I investigate these issues separately even though each play is involved in all of them at once. Precisely in their activation of such a wide range of issues, Lohenstein's texts trouble the knowledge that the scholar of early modern gender systems has of 
her object of study in several ways. They cause her to wonder what the plays may have meant in their time, but caution her to acknowledge that it may be impossible to lay hold of any final version of this meaning. For at the very moment when she stays as close as possible to her texts, they seem to become - and to have been designed to become-impossibly mobile, embedded in the dense world of learned tradition and contemporary material and political circumstance that accompanied and shaped gender ideology at the time. This world consisted not only of texts that attempted to recapture the classical past in complex ways, but also in a remarkable degree of self-consciousness about political developments and relations with cultures far beyond central Europe that might impact the way in which the ancient world is seen (see chapter 4). The very density of these texts persuades her, in turn, that the view she has gotten of the period and of its cultural production to date has been partial, due to the absence of an analysis of such confusing data as these plays. In critiquing the elisions of prior scholarship, I acknowledge that component of my reading that is merely reformist, that seeks to "do better philology" and "better" early modern gender studies in order to finally "get it right." Yet, by "adding and stirring" a bit of early modern eastern central Europe into the mix, this component also complicates (rather than stabilizes or completes) the image we have of the relationship between gender, power, and learning in the early modern period in general. As a result, the disciplines I invoke here may have to rethink their own intellectual geographies and methodological economies, and this is a good thing.

\section{The Worlds of Daniel Casper von Lohenstein}

As much as the preceding pages have argued for the matter and method of this book as a staging of postmodern disciplinary, methodological, and theoretical intersections of several sorts, it cannot be overlooked that they also primarily concern what appear to be the excesses of early modern pedantry in east central Europe; outside of a small guild of scholars of the German Baroque, Lohenstein's plays have for the most part been considered (when they have been considered at all) as the "exotic effluences" of a time long ago. ${ }^{71}$ The marginalizing images of Lohenstein's oeuvre that have been produced by several literal and figurative disciplinary borders and political zones are the subject of the conclusion. Here, however, I want to begin to make his texts central again to discussions of early modern European culture in general by reembedding them in the complexities of the world out of which they 
emerged, complexities that concern all of the major political, religious, cultural, and commercial developments of the time. Tomes have been written about the historical political, economic, military, and cultural "maps" of early modern Silesia and Breslau. There is thus much that is necessarily left out in the brief overview that I provide here. ${ }^{72}$ Yet these broad outlines will help reorient both initiates and newcomers in the context out of which Lohenstein's plays grew. His was a world in which identities of all kinds competed with one another for visibility, power, and prestige, a world in which borders, reference points, and structures of political and cultural organization were as mobile as those in the texts that I discuss in the following chapters. Examining the heterogeneities of early modern Silesia as products of the multiple economies of religion, power, and commerce that intersected in the center of the European part of the Eurasian continent up until and including Lohenstein's time can serve as an example of how to make central rather than "marginal" those new knowledges about early modern eastern central Europe that will be necessary for redrawing the "map" of the discipline of post-Cold War early modern studies.

The areas of east central Europe known as Silesia (Schlesien) can be found for the most part in the late twentieth century in and along the western corridor, or borderland, of the nation of Poland as it meets the Czech Republic and German states (Länder) of Saxony and Brandenburg. Its literal geographical parameters spilled over these borders, however, in both the early modern period and since to include parts of what is now Germany. Silesia's shape has often been compared in the popular imagination to an oak leaf that fans out to the east and the west along the central artery of the Oder (Odra) River between Frankfurt an der Oder and contemporary Cesky Tesin (Tschechen) and the "veins" of the Oder's many tributaries as they disperse through the region. Yet trying to pin down the exact coordinates of Silesia with such an organicist image belies both past and modern realities there, for its history can in fact be said to have been constantly in motion, coinciding as much with the histories of both the independent and imperial lands of Poland, Brandenburg, Saxony, Bohemia, Moravia, and Hungary, as well as some twenty tiny and relatively independent principalities within Silesia itself, in the "longer" early modern period, as with the "histories" of the nations of Germany, Poland, and the Czech Republic today. Depending on where one stands and where one looks, Silesia existed in many places at once.

This historical mobility is nevertheless thought by many to have come to an abrupt end in 1945, Silesia's changing identity and borders ironically stabilized through elision, when the majority of the territories as- 
sociated with it, occupied and governed by the National Socialists during the war, was finally "awarded" to Poland in Potsdam after lengthy bargaining between the Soviet Union and the "western" Allies, who saw these areas as traditionally German even before the Nazi invasion and atrocious resettlement policies made it part of the Third Reich. Even political adjudication by the victors was not able to define Silesia for good or render it static, however; well into the postwar period, it continued to occupy several locations at once when, in a perverse reenactment of all too recent history, nearly 8 million Germans and ethnic German Polish-Silesian citizens were displaced - as earlier inhabitants of Silesia had been under the Germans--driven (in this case, driven west rather than east) out of their homes under the new government. Some 1.5 million people are said to have lost their lives in the process. Several million Poles were then "repatriated" to what had been Silesia from eastern Polish territories "lost" to the Soviet Union in the hope that their presence would invest the literal geographical space with a Polish identity once and for all. Yet, at the same time, many Silesian exiles in West Germany attempted in the 1950s and 1960s to "save" the memory of their homeland after it had slipped into oblivion behind the so-called Iron Curtain by recreating Silesia abroad in a variety of cultural, political, and scholarly projects, projects that claimed that the "real" Silesian spirit and Volk survived in the West during the Cold War (see conclusion). Even though Germany officially gave up any claims on the Polish territories formerly associated with Silesia in 1991, academic struggles over its historytheir varying loyalties marked by the several different languages in which they are written and only barely masked by claims of common interests - continue to indicate that Silesia's ideological (if not also literal) location and identity are still objects of contention at the end of the century. The verdict of where Silesia is and was is still out.

What does appear to be clear, however, is that even though the contemporary U.S. observer, whose vision is still colored by the rhetoric and realities of the Cold War, might characterize the area once known as Silesia as the "beginning of the East," the historical actors on the stage of central European history more often than not considered it to belong to and to be the front line of the West. In 1241, for example, when the Mongols invaded Silesia as part of a split-front attack on Europe, Henryk II Pobozny (Henry the Pious) is said to have lost his life at the Battle of Legnica (Liegnitz), later an important Silesian town, in a valiant effort to protect the Occident from "oriental" incursion; the Mongols "miraculously" stood down, bequeathing to Henry's Piastian line, which had been one of the ruling families of Poland since the ninth century, a powerful mythical identity as defenders of the "civilized" world. 
The nearby city of Breslau (Wroclaw) was founded soon thereafter; by the Enlightenment, if not before, it was home to cultural and scientific achievements much celebrated by the "western" world. The embeddedness of Silesia's identity in all of the major political and military conflicts that consumed Europe during the Reformation and the Thirty Years' War (1618-48) further testifies to its involvement in the central concerns of the early modern age. After the multiple dissections of Poland's borders and political selfhood that occurred during the 1770s and 1790s, the Treaty of Versailles uncannily reproduced the very same West-identified geography of identity for Silesia in the early twentieth century as had characterized it some seven hundred years earlier when it (re)created Poland as a national entity in 1918-19. Because the nation remained caught between competing spheres of interest and fronts in the years that followed, the "borderlands" of Silesia retained a distinctly "western" identity as Poland remained locked in struggle over its eastern borders with the Soviet Union until 1932. Characterized as a "deutsche Bollwerk" (German bulwark) in the east, Silesia had become a "Grundpfeil [der deutschen] Ostfront" (fundamental pillar of [Germany's] eastern front) by 1938, an "eastern front" of a fascist "West," so to speak, which was to move even further eastward in insidious ways in the coming years. ${ }^{73}$ It was only after the war, in Potsdam, then, that the former Silesia took on the status of the "western front" of the East even as it effectively disappeared. If the national history of Poland in general is hard to tell as it moved in and out of existence, tracking the multiple identities of a traditionally "western" Silesia captures the difficulty of locating the "essence" of eastern central Europe's mobile history in both early modern and modern times.

Silesia's "western" orientation was itself multilayered, of course, produced by numerous demographic, political, confessional, and even linguistic developments beginning already in the medieval period and extending through the Reformation up into the early modern period when Lohenstein lived and wrote his plays. As indicated already, this "westernization" was more often than not associated with narratives about Silesia's links with and integration into traditionally German cultures. Scholars have argued, for example, that for reasons similar to those that drove population movements throughout Europe during the high Middle Ages-among them, the need for increased manpower in both the agrarian and commercial sectors and the availability of land - there was a large influx of "immigrants" from "old Europe" to the relatively less well populated areas of eastern "new Europe" in the thirteenth century. In its very designation as "Ostsiedlung" (eastern settlement), this movement suggests that an originally "eastern" Silesia only became 
"westernized" with the influx of the historically German newcomers from the more "modern" areas of the Reich. Whatever the geographical coordinates of modernity may have been during this period, it is the case that by the fourteenth century, Silesian students studying in Prague, for example, were in fact said to belong to one of the three German "Universitätsnationen" there; by the fifteenth century, the major language of Lower Silesia in particular was German, especially in the cities, even though multilingualism of several kinds (Polish, German, and Czech, but also Latin and Yiddish) still characterized many parts of the area up through the seventeenth century and beyond. ${ }^{74}$ The local Piastian ruling families also considered themselves culturally German during early modern times.

Politically, Silesia became a part of the hereditary lands ("Erbländer") of the powerful house of Luxemburg in the fourteenth century via incorporation into the kingdom of Bohemia, and then passed into this same direct relationship of submission, yet also alliance, with the Habsburgs in 1437 when the last Luxemburgian emperor, Sigismund, died without a male heir, and the Habsburg Albrecht II married Sigismund's daughter, thereby inheriting both Bohemia and its Silesian satellites. These political alignments ultimately resulted in Silesia's major orientation toward an imperial court deeply implicated in central and western European history throughout the late medieval and early modern periods (rather than toward the nonhereditary lands overseen by the Reichstag, for example) as the Habsburgs extended their reach into areas now considered to have most recently belonged to the East bloc. In spite of its subordination to the Empire, Silesia - along with Bohemia as its intermediate superior - was and remained during this period the beneficiary of the special privileges that had been accorded to these territories beginning with Emperor Charles IV in his Golden Bull of 1356 and maintained for several centuries thereafter to varying degrees.

The powerful Charles presided over one of the most progressive and internationally well connected courts in Europe for nearly thirty years and developed a highly complex imperial bureaucracy to coordinate his vast lands, the major geographical coordinates of which were Prague, Nuremberg, Breslau, and Frankfurt am Main. The number of Silesians seeking fame and fortune at his court can be explained by their linguistic talents and thus suitability to his administrative needs, although the obligations created between the Empire and Silesia as a result of the marriage of the emperor to Anna of Schweidnitz-Jauer, an important Silesian duchy, surely also played an important role. The subsequent centuries of Habsburg hegemony over Silesia were interrupted only briefly by the reign of King Matthias Corvinus of Hungary, who from 
1470 to 1490 ruled over Silesia as his part of the divided Bohemian territories. It eventually reverted to Habsburg control after two decades of struggles for hegemony between the conflicted leadership of Poland, Hungary, and the Empire, when in 1526, Archduke Ferdinand of Austria was named Emperor Ferdinand and Silesia reentered the Habsburg domain. The "Hungarian" period is nevertheless said to have allowed Silesia to begin to see itself as somewhat autonomous in relation to Bohemia in particular, if not also vis-à-vis its Viennese masters. Yet it was also a time when all eyes in eastern Europe were focused on the Turks. The fall of Constantinople to the Ottomans in 1453 had been hugely significant for both Hungary and its Silesian lands, for with their victory came Turkish expansion into the West on whose foremost frontiers many of their territories lay. A leader like Ferdinand, on whom they could rely to protect them from the Turks, was the one the Silesians desired, even at the expense of some of their more local freedoms.

A spirit of autonomy, even self-determination, had nevertheless also traditionally been associated with the Silesian Piastians. Both this selfimage and more practical political needs had led them to enter into numerous dynastic alliances with other powers; multiple marriage contracts, as with the House of Hohenzollern, for example, in 1536-37, sealed such agreements and set the Piastian princes at odds with the Empire even as they increased their sense of local identity and pride. These marriages of course in no way stabilized Silesia's political future, for, in the event that the Piastian side of the partnership should die out, the bigger brothers of these alliances were designated to take over its lands. The possibility of a greater sphere of political and military influence for Brandenburg in particular - and the likelihood that it would provide a model and precedent for others-was, of course, something that Emperor Ferdinand could not tolerate; he attempted to call an abrupt halt to such developments in 1546, the same year as his Schmalkaldian War against Johann Friedrich of Saxony and Philipp of Hessen, by annulling the inheritance pact signed by Duke Friedrich II of Liegnitz and Joachim II of Brandenburg some ten years before. His actions nevertheless could not stop Joachim Friedrich of Brandenburg from attempting to activate the inheritance system half a century later, when he made his son, Johann Georg, the duke of Jägerndorf, Beuthen, and Oderberg after the death of the last Piastian there in 1603. Whether Silesia was more Brandenburgian, more Piastian, or more imperial during these years is difficult to tell. Perhaps it is best to think of it as having been all three at once.

Beginning already in the high Middle Ages and extending through to the early modern period, then, the history of Silesia appears to have 
been implicated more with the histories of Bohemia and Moravia than with the history of Poland because of their common membership in the Empire, although their relations, especially between Bohemia and Silesia, were not always peaceful ones. And yet, various constituencies, especially among the representatives of Rome, reached out to their immediate neighbor to the east for support over the years. There had been, after all, a tradition of close ties with Poland since the fourteenth century, when Prince Jagiello of Littau secured rights to the Polish throne by marrying the Hungarian princess Jadwiga (Hedwig), whose father had ruled both Greater Poland and Silesia. The "Jagiellonian period" in Poland lasted until 1572. The differentiation between Lower Silesia and Upper Silesia, which dated to the year 1202, may also have contributed to a kind of bipolar orientation that favored a north-south axis of political identity for Silesia as much as it favored an east-west one. The southern territories of Upper Silesia seem to have become more identified with the Empire for sheer geographic reasons, if not also political and religious ones, and the northern territories of Lower Silesia, centered around Breslau and somewhat further away from the imperial centers at Prague and Vienna, became more autonomous in turn. Successive emperors of course did travel to Breslau where the Silesian Stände (estates) had to pay their respects on the Kaiserburg (imperial residence) there; that the ceremonies took place on what was the symbolic "home court" of the emperor indicated Vienna's need to assert its authority over Silesia even if the emperor himself resided far away. The success of the Reformation in the northern parts of Silesia has in fact been attributed to the sense of independence that Lower Silesia nevertheless enjoyed, as well as to the flourishing of humanism both in the cities and at the courts and the positive reception that such religious radicals as the Hussites and Kaspar von Schwenckfeld experienced there. The appeal of a religious movement that would allow a still technically subordinate Silesia a greater degree of political autonomy should in any case not be underestimated.

The confessional picture of Silesia during the early sixteenth century and in terms of the religious conflicts that consumed central Europe at the time is no more stable, however, than either its "official" political status or its unofficial sense of self. Good relations between Breslau and Nuremberg had led to the appointment of the future Reformer Johannes Hess to a position in Breslau first in 1513 and then again in 1523 after he had made contact with Luther and Melanchthon in Wittenberg; most of Silesia became thoroughly "reformed" in subsequent years. Yet, the presence of the bishop in Breslau nevertheless meant that the Reformation was not introduced with such vehemence in Silesia as elsewhere. 
Church lands were not secularized and Catholic Church services continued to be held. In spite of the potential for conflict that such odd bedfellows in Silesia could have created, documents do survive that indicate intentional levels of mutual tolerance, as in the agreement between the bishop and the Protestant city council of the town of Sprottau in 1565 that Catholics and Protestants could each go their own way and leave the others in peace; no radical attempts to convert the one or the other set of believers were to occur. ${ }^{75}$ On the basis of this and other similar kinds of agreements, much has been made of an ongoing Silesian tradition of religious tolerance even before the issue of local religious "choice" became a matter of official legislation in Augsburg in 1555.

From the point of view of the Jewish population of Silesia and in light of the several pogroms that occurred in the fifteenth and sixteenth centuries, such claims of tolerance were, of course, premature. Yet, there were several famous exceptions in Silesia to these acts of terror, notably the Piastian principality of Oels, which was hospitable to Jews until 1535 and which could thus boast of one of the oldest Jewish printing houses as well as a magnificent synagogue modeled on the synagogue in Prague. The tiny cities of Zülz and Glogau also remained tolerant, and, along with nearby Breslau, became the destination of many Polish and Viennese Jews who fled there in successive waves up through the seventeenth century. Although the Jews were banned from the remaining territories of Silesia in 1582, the presence of these exceptional communities and the practice of granting "privileges" and residency permits to the extended families of merchants, printers, and doctors led to the growth of a large Jewish community in Breslau by virtue of permissions for second residences being granted at the same time. ${ }^{76}$ The transfer of the Jewish community's talents and goods to Prague because of forced emigration from other parts of Silesia nevertheless created quite close at hand one of the most populous and culturally rich Jewish cultures of its time. The religious leadership of this community ironically enjoyed the interest of the idiosyncratic but learned Emperor Rudolf II, who had issued the ban. Tolerance became official once again in Silesia when it entered its Prussian phase. Remembering these pockets and periods of apparent philo-Semitism in Silesia is, of course, difficult in the face of the knowledge that, many years later, the town of Oświecim (Auschwitz) technically became part of "New Silesia" after 1936. Depending on where and when one looks in and at Silesia, then, questions of religious tolerance appear somewhat different, if not incredibly heterogeneous even in a single place and time.

In the matter of cuius regio, eius religio (whosoever rules, let his religion be followed) declared at Augsburg in 1555, however, Emperor Fer- 
dinand let it be known that he himself-rather than the local rulers in Silesia - would be the instance whose religion would be followed in the territories that belonged to his "traditional inheritance." Ferdinand's authority and, by implication, the power of subsequent Catholic emperors were challenged by the effective hegemony of Protestantism at the smaller courts of Silesia by the end of the sixteenth century and by the turn of the Piastian dukes of Liegnitz, Brieg, and Wohlau in particular to Calvinism in the early seventeenth century. The mutual respect for these differing beliefs in evidence under Emperor Maximilian II, whose tolerance of Protestantism was much higher than his predecessor's, came to an end after the brief career of the Winter King of Bohemia, Friedrich V of Pfalz, whose initial popularity in Silesia can be explained by the widespread Protestant and even Reformed loyalties there. The fact that the Silesian Stände (estates) supported their Bohemian counterparts in the "revolutionary" election of Friedrich as king of Bohemia and in the Act of Confederation signed in Prague in 1619 may have been based on their common resistance to the Catholic Habsburgs. It nevertheless also led them to be the objects of Emperor Ferdinand II's more thoroughgoing plans for the re-Catholicization of Silesia in 1625, a counter-Reformation that became a condition of the official peace treaty with Vienna later in 1635.

The intervention of the Kurfürst of Saxony prevented brutal punishments of the rebels in Silesia of the kind that occurred in Prague in 1621. But the subsequent reassignment and even purchase of Silesian principalities by pro-Habsburg forces ultimately had the same effect. As the armies of Sweden and its allies, Saxony and Brandenburg, and those of the Empire swept back and forth across Silesia in subsequent years, the terror of the populace in the face of confessional strife was only increased by the devastation of war. The Piastian princes of Liegnitz and Brieg, in fact, fled their lands, and the duke of Oels was placed under arrest. Yet, in the Treaty of Westphalia that ended the three decades of conflict, it was these very Silesian principalities as well as the city of Breslau that retained the privilege of a local freedom of religion, probably because of a tradition of granting such freedoms to them, but also because of their political affiliations with Saxony and Brandenburg. At the same time as 656 Protestant churches were closed in the emperor's hereditary territories and some 500 Protestant ministers forced to flee, the Piastians were permitted to build several massive "Friedenskirchen" (peace churches) in Jauer, Glogau, and Schweidnitz; each could accommodate several thousand worshipers. As tiny as these Protestant enclaves of Silesia after the end of the Thirty Years' War may have appeared to be, then, in comparison with the rest of the areas of central Europe re- 
Catholicized by the Empire, they were of mighty significance to the surrounding Protestant powers and lands, who measured the temperature of the powers in Vienna according to their ability to keep to the guarantees made to Silesia in these years. Both victim and beneficiary of multiple relations and economies of power during what has been called the "century of crisis" (1560-1660), Silesia presents a historical-interpretive challenge during these years. The closer one gets, the more complicated the multiple layers of confessional and political identity become.

This complexity was in no small part the result of a peculiar tradition associated with the Silesian Piastians. One of the legacies of their leadership was the expansion, yet also the fragmentation of the extended family's political power due to an inheritance practice that awarded small, independent duchies and principalities to multiple sons. In cases of death or no surviving male offspring, these were either reassigned or bequeathed to other members of the family in an elaborate hierarchy of seniority. Uncles and cousins could thus be put in the position of either consolidating diverse "kingdoms" or further distributing them in turn. Women could even be asked to function as dynastic "placeholders" until still underage sons reached their majority. By 1327 this custom had created some sixteen individual principalities in Silesia, the high number necessarily dictating increasingly smaller "fiefdoms" for all concerned. This number reached approximately twenty over the next three hundred years, and produced maps of Silesia before, during, and after the Thirty Years' War that resemble nothing so much as elaborate jigsaw puzzles with the pieces constantly being recolored, rematched, and refitted to reflect new leaders and assignments of land..$^{77}$ The Piastian inheritance system also produced a complex, even somewhat schizophrenic network of loyalty codes, because many of the principalities saw themselves obligated to their local princes and dukes, for example, first and foremost, with the king of Bohemia and even the emperor, who were technically their superiors, only in second place. Yet, it also produced odd exceptions to standard gender ideology in the cases when women were asked to rule in the place of men.

The forfeiture or bonding over of these small kingdoms for military or financial reasons, the failure to produce male heirs, and the gradual dying out of various branches of the family (the last male Piastian ruler of Teschen died, for example, in 1625, and the principality was assigned for "private use" and not for ruling to his surviving sister) combined to produce unstable political relations throughout Silesia in the seventeenth century in particular, as Vienna and Prague looked for "leaderless" principalities to award to loyal supporters. When the very last Piastian prince, the young George William, in whose fate Lohenstein 
took such great interest (see chapter 3), died in 1675, Vienna moved in with a vengeance and the Piastian lands were effectively absorbed. In this context, it is no wonder that marriage alliances had always been crucial for the Piastians, not only for increasing the size and reach of their lands in earlier years, but also for protecting themselves from the Empire by means of networks of obligation developed with the more powerful ruling families of Brandenburg and Saxony and even with the kingdoms of Bohemia and Poland in later times. The self-image with which such partnerships invested these local princes and dukes helps explain how Henry IX of Liegnitz, for example, although somewhat of an eccentric, could have even considered making a marriage offer to Elizabeth I of England. But it also clarifies how the "Silesian question" was kept alive throughout the era of politicoreligious wars.

The multiplication of tiny courts throughout the "Oderland," each with aspirations of grandeur as well as with serious local economic, political, and military obligations, resembles nothing so much, then, as the variegated relations of ruling in the Italian city-states of the Renaissance. It also anticipated, however, the development of the local state structures of early absolutism in the seventeenth and eighteenth centuries in Europe in general. The urban center of Breslau, which in its autonomy thought of itself as akin to a free imperial city, in turn often saw itself in a kind of natural alliance with this intermediate class of Silesian rulers over against the "universal" state apparatus located now in Prague, now in Vienna. Multiple traditions of both local and urban "patriotism" thus existed sometimes uneasily and always in fraught ways alongside and within the greater structures of technical imperial hegemony and foreign domination of Silesia well into and beyond the Thirty Years' War.

Originally the site of one of the major crossings over the Oder River, Breslau itself was both naturally and traditionally the center of Silesia, both politically and commercially. Raw products, such as salt and metals from the east were exchanged there for finished products from the west. Its status as a major European intersection and crossroads only increased during the "Hungarian" years in the late fourteenth century, when new roads to the east were built to open up the eastern market to the goods of the west that traveled through the city. A sign of its visibility in and to the rest of the continent is the fact that the mighty Augsburg firm of Fugger, bankers to the emperor and financiers of exploration in the New World, opened an office in Breslau in 1487 and began to invest in local mining ventures in the Mittel- and Erzgebirge as well as to trade in exotic goods from the Far East through their contacts there. It was thus that the local cloth industry took a second seat to the com- 
mercial activities of the town. Although the city's great commercial success was the source of its power, it also often proved to be the origin of political tension and social unrest. New immigrant businessmen and traders wrestled with the old and established patrician merchant families of the city for market control, for example, or came to blows over the tax structures imposed on their prosperity throughout Breslau's early modern history by Matthias Corvinus to serve his expansionist military needs and by the Empire to finance its ongoing wars with the Turks. Emperor Ferdinand I cleverly "allowed" the city to take responsibility for collecting these "war taxes" at one point; the issue became a highly divisive one in the city and its surrounding lands due to underreporting of income and assets among many. Ferdinand went on to impose tax after tax - on beer, on cattle-as well as a series of commercial import tolls in a series of muscle-flexing gestures also designed to provide him with the much needed revenues. The imperial tax agency established in Breslau in 1558 further subordinated the city to Vienna in spite of its strong position in terms of the crown's needs, a position of course based on precisely these same monies. Whether the urban coffers were half full or half empty was a question of point of view.

In religion as in commerce and politics, Breslau was characterized most by its internal hybridity. It had become the see of the bishop in 1000 , thereby acquiring an additional measure of prestige, yet also of political and cultural complications for the town. Because its income and incumbents were traditionally associated with and assigned to the local nobility, the cathedral (Domkirche) there had become a center of Polish loyalism by the thirteenth century. This resulted in the tensions between church and civic authorities that became central to the confessional standoff both in Breslau and in Lower Silesia in general during the Reformation and up through the Thirty Years' War. The church was even forced to appeal to its Polish neighbor for recruits during the high point of the Reformation, as it could no longer find enough local talent interested in the priesthood. It nevertheless became stable enough to be able to welcome Catholic refugees into Silesia during the Polish war with Sweden in 1655-60 after the majority of the territory had been reCatholicized by imperial demand.

At the same time, however, and in spite of the high profile of the bishopric in the city, it was the Breslau city council (Rat), documented to have existed in Breslau since 1266 and for the most part Protestant by the mid-sixteenth century, that considered itself the de facto political authority in the city. Vienna sought to delimit the membership of the Rat and the identity of its leadership to various subgroups (such as "citizens of Silesia" or non-nobles) by means of various edicts and treaties 
with both the Empire and the church at various times, but the Rat conceived of itself as being in direct competition with, if not also superior to both the Landeshauptmann (provincial governor) appointed by the Empire and the bishop of Breslau. A painting dated to 1537 in fact shows the members of the council in the guise of the Apostles at the Last Supper, paying homage to a patrician Christ. ${ }^{78}$ The conflation of religious and political authority and thus the terms of the local struggle for power are captured in the image. Try as they might, however, the members of the Rat could not prevent the allocation of the Breslau Burg to the Jesuits by the emperor in 1659, for example. This somewhat more than just symbolic act was accompanied by the reassertion of tax and judicial authority over Silesia by Vienna, in the wake of the end of the Thirty Years' War, as the agents of the Empire, the city, and the surrounding principalities jockeyed for position and power throughout the decades following the treaties at Münster and Osnabrück. Ascertaining who was in charge in Breslau at this particular moment in Silesia's history - as in others too-would probably have been very much a function of who one asked.

Both Silesia in general and Breslau in particular thus had far clearer, if also quite vexed, profiles in the early modern mind than they may have in most parts of western Europe today. A series of figures testifies to yet another reason for the city's visibility, namely its considerable size. In 1500, Breslau was the largest European city east of Prague except for Danzig. It boasted of a population of some 18,000 to 20,000, and was larger than Cracow, Vienna, Frankfurt am Main, and Basel at the time. Only Nuremberg was bigger. By 1618, Breslau's population had risen to nearly 30,000 , only to fall again after a devastating attack of the plague in 1633-34, in which the city lost nearly one-half of its inhabitants $(13,231)$. The combination of forced migration and an influx of immigrants that accompanied the several decades of religious and political conflict obviously contributed to an overall decline, which nevertheless was halted well before the end of the century. Thanks to immigration for political, religious, and commercial reasons, the city's population reached its prewar levels again by 1670 (the year in which Lohenstein became Syndikus) and continued to grow, reaching nearly three times its 1633 population $(15,000)$ by $1710(40,890)$. Lohenstein thus may have been born into a dangerously contentious world on the brink of collapse in 1635 , but he came of age in a city experiencing the benefits of a certain stability and peace. With population growth came the expansion of the local bureaucracies into which both he and the students of the Protestant Gymnasien were to work. Professional training and political connections became the basis for success in an increasingly postconfessional world. 
The highly complex political nature of Lohenstein's plays is thus illuminated by their origins in a world in which multiple instances of civic, provincial, and imperial authority had competed for sovereignty for well over 150 years. The dense learnedness of the texts also makes sense when we consider Silesia's and Breslau's multiple intellectual traditions. Although a cathedral school is documented as the oldest educational institution in Silesia (founded in 1202 in Breslau), the Pfarrschulen (preaching schools) of St. Maria Magdalena (1267) and St. Elisabeth (1293), with their city backing, soon began competing with it for prestige. These were to become the schools whose students produced Lohenstein's plays. The absence of a university in Breslau led both the local nobility and the city to attempt to secure permission to found one a number of times, but their requests were not fulfilled until 1702. The forced "intellectual migration" of Silesia's students to the universities of Paris, Bologna, Prague, Leiden, Leipzig, Vienna, and Cracow that resulted prior to that time nevertheless ultimately created a kind of academic internationalism in their homeland when they returned. Moreover, the contacts made during their studies at these major European institutions throughout the sixteenth and seventeenth centuries led members of Silesia's learned elite to be summoned back to positions at these and other universities in later years. The cosmopolitanism that characterized the academic careers of these men is in turn everywhere apparent in the intellectual universe inventoried in Lohenstein's notes.

Local innovations in "modern" schooling methods had prepared Silesia's students well for their subsequent successes abroad. Among these was the work of the great pedagogical theorist Valentin Trozendorf, whose impact in east central Europe rivaled that of Straßburg's famous Johannes Sturm in the west. Trozendorf taught in the Goldberg school under the sponsorship of the Piastian dukes of Liegnitz; his school and curriculum became the model for other Gymnasien in Silesia, including those in Breslau, as well as in Brieg, Oels, Görlitz, and Beuthen. The tradition of learning to which these schools testify explains Philip Melanchthon's comment in the sixteenth century that he knew of no other Volk in Germany that could boast of such great learning as the Silesians. Throughout the seventeenth century, it was primarily the Jesuits whose work enhanced this reputation for a commitment to education in Silesia, as they made contentious inroads into many of its leading towns, usually founding schools when they came. The Jesuits arrived in Breslau, for example, in 1638 and had established their own Gymnasium there by 1642 . Their plays are said to have provided the impetus for the increasingly elaborate dramatic productions at the Protestant schools, where Lohenstein's Roman plays were part of an effort to attract students away from the rival Catholic schools. 
Learnedness was a goal, finally, not only among the students of Silesia or, more specifically, in Breslau. Many of the smaller courts, Piastian and otherwise, were veritable scholars' paradises, with magnificent collections of manuscripts and books. The Catholic monasteries also possessed astounding libraries, and even a bourgeois citizen like Thomas Rehdiger was able to assemble a collection of some six thousand volumes of precious material and bequeathed it to the city of Breslau at his death in 1575. It is no wonder, then, that along with the dramatists, Andreas Gryphius and Lohenstein, such famous poets and thinkers as Opitz, Jakob Böhme, Johannes Scheffler (Angelus Silesius - the "Silesian Angel") as well as the somewhat younger philosopher Christian Wolff, all hailed from Silesia. The work of these men and others was the product of a nearly hothouse environment of intellectual and cultural exchange. They represented not just "local" talent, however. Many Silesian figures also enjoyed reputations in the culture of greater Europe as well. The Breslau doctor, Philipp Jakob Sachs von Löwenheim, for example, founded one of the earliest European scientific periodicals, the Miscellanea Curiosa Medico-Physica oder Ephemerides Academiae Naturae Curiosorum, in 1670, still in existence today. The powerful church inspector, Kaspar Neumann, who began recording mortality statistics in Breslau in 1687, shared the results of his study with colleagues in England, who in turn published Neumann's data in the Philosophical Transactions of the British Royal Society; the collaboration led to the establishing of the first life insurance companies in the West in 1706. The urban and courtly, the political and intellectual worlds in which Lohenstein moved and the people whom he could have met were thus of international stature. Knowledge, personnel, and books were constantly in motion and local events took on a broader significance as part of the central cultural developments of their day.

That so little is known by so many today about the complex political, confessional, and intellectual realities of Lohenstein's worlds is an effect not of his historical location, then, but, rather, of where scholarship about the early modern period has stood for so many years. The chapters that follow are designed to enter into and engage the complex realities of early modern eastern central Europe at the level of and in the matter of plays written and produced in Breslau in the second half of the seventeenth century, plays in which we find in textual form the same hybridity, polyphony, and mobility that characterized Silesia itself. Where and how we look at them will determine what we see. 


\section{Sophonisbe (1669) and the Text That Is Not One: Hybridity in Historiography}

\section{Playing with History: The Past That Is Not One}

Just shy of midway through the famous dedicatory prologue to the last of his Roman plays, Sophonisbe, produced in 1669 and published in 1680, Lohenstein, already well into the so-called age of the New Science at this point, subtly disputes the claim that the Moderns can move in any uncomplicated fashion beyond reliance on the Ancients for insights into the laws of nature. The position seems to be a logical one, given the context - namely, a revivalist play about the victory of ancient Roman values and virtues over the "barbarism" and passion of its African adversaries in the Second Punic War. The classical tradition, embodied in Rome as an imperial power, would appear to be superior to the present, especially in its function as cultural capital, in its very power, that is, to be the matter of plays such as this one. The story of Sophonisbe and the defeat of her people, the Numidians, by the famous Roman general, Scipio Africanus, thus appears to be supremely appropriate as a vehicle for the articulation of a kind of imitative historiography in dramatic form. Examples derived from ancient texts are selected strategically and used allegorically to comment upon political situations as proper to the Holy Roman Empire in Lohenstein's day as they were to their origins in ancient times.

And yet, as much as Sophonisbe, like Lohenstein's other plays, appears to rely on reproducing for the early modern school stage traditional (hi)stories of the classical world, here of the Second Punic War as rendered in Livy, Appian, and Dio Cassius, replicating in its very submission to textual tradition the dominance of Rome that the play takes as its theme, the play in fact does not inherit its classical sources in any traditional way. Indeed, its very extravagances, both as text and as script, would seem to set it apart both from what have conventionally been understood as the sedate texts of early modern historiographic tradition and from the myriad Roman plays that crowded the stages of Europe throughout the period. ${ }^{1}$ These extravagances belong to an inventory of symptoms that indicate that, far from being beyond relying on the Ancients, late humanist Moderns in central Europe like Lohenstein were still very much concerned with questions of how to engage the past in 
their own resolutely postclassical age. This concern was particularly apparent in the tradition of political philology that was widespread at the time, which used the tools of humanist learning in the service of the practical politics of the day; elaborately annotated editions of Roman historiography pointed out the parallels between the past and the present, and explicitly noted the lessons to be learned by those engaged in contemporary politics and diplomacy. ${ }^{2}$ The Sophonisbe prologue figures both this specific historiographical tradition and the more general issue of the difficulty of calling up the past in such a way that the intervening moment of the present becomes textually palpable. For this reason I begin my analysis of Lohenstein's plays with it. Prefigured at this particular moment are some of the textual dislocations of history that both provoke and help explain other dimensions of excess both in this play and in Lohenstein's oeuvre as a whole. "Slow reading" affords access to these dislocations as they occur beneath the surface and in the margins of his texts.

The main issue that Lohenstein examines in the Sophonisbe prologue, namely that of Spiel (play), itself addresses the relationship between past and present, between Ancients and Moderns, by defining change and the protean powers of time and nature as its main concern. The stage production was, of course, itself also a literal play and thus functioned as a kind of commentary on the inevitable gap between past events and the here and now; its reliance on boy actors, whose bodies literally did not and could not re-present on stage either the female title character of their script or her deliberately erotic and otherwise highly charged acts, also interrupted the possibility of reproducing the matter of classical history on stage in any easy way. I examine the boy actors and their inscription in, but also resistance to, a number of ideological and institutional identity formations in chapter 2 . In this chapter, I focus on the extent to which Lohenstein's historiographical and philological project in Sophonisbe is produced by but also shapes the gender politics of the play. The text responds to developments in early modern historiographical and text-critical tradition with what may initially seem to be idiosyncratic, even excessive manipulations of characters, production techniques, and plot. These solutions, particularly as they concern gender, can nevertheless be seen to make sense if we reconceive of them as implicated in the period's debates about (re)creating the past in textual form. Textual and sexual economies thus parallel and mutually illuminate one another here. ${ }^{3}$

Using gender to engage in debates about imitating the past was, moreover, not merely or, perhaps better, was precisely academic, in an early modern world in which the very schools in which the skills necessary for accessing ancient traditions were taught within the context of 
institutions whose mission it was to produce the early modern male pedagogical-political subject as a future member of the educated civilservant class. Lohenstein's stance in his school plays (Schuldramen) on the (non)reproducibility of the Roman imperial mind-set and paradigm was thus of no little interest, given his position not only as one of the more or less "official" playwrights of the Protestant schools in Breslau, but also as legal advisor to a city whose relationship to the Holy Roman Empire had always been and continued to be a fraught one precisely during the years that he wrote. The distance between the German play and the Roman model texts Lohenstein used when composing it may well figure the gap between the city of Breslau and the Empire at the time, a gap that the boys had to be taught to understand. The complex relationship between a local, civic body politic, the imperial center at Vienna, and the schools as the breeding grounds for the future functionaries of the early modern state at both levels is a paradigm of the kinds of difficult power sharing and power negotiation that were more often than not the norm in early modern central Europe. The intricacies of this relationship and of the competing loyalty codes that politicians like Lohenstein had to somehow balance against one another are mirrored in the complex relations of the play to its sources as well as in the boys' relationship to their roles.

At a textual level, Lohenstein's version of Sophonisbe's life and of her demise reveals a sense of historical self-consciousness that follows a principle of "non-oneness," one that coincides with Luce Irigaray's characterization of female sexuality as "not one," as "multiple" and "diffuse," and as resistant to organization and containment within a (phallic) economy of stable hierarchies, clear boundaries, and clean lines. ${ }^{4}$ It is not by chance that the playwright consistently focuses on female protagonists, in this case, Sophonisbe, and her tense and steamy relationships with two African kings, Syphax and Massinissa, in the drama of Rome's confrontation with its African adversaries, rather than on the more obvious and, indeed, historiographically more visible male colonial personality of the Second Punic War, namely Hannibal, at the end of the second century B.C.E. ${ }^{5}$ In her very sexed body, Sophonisbe embodies the principle of difference that characterizes Lohenstein's relationship to the texts of history available to him at the time; in the choice of the female, moreover, we find represented not only a figurative challenge to an imitative poetics of historiography, but also an intervention in the monolith of a homosocial (Roman) history that would cast all stories of political conflict as battles just between men. ${ }^{6}$

The textual non-oneness of Lohenstein's play about Sophonisbe thus indicates an almost modern, if not also postmodern self-consciousness about the historical imagination and project, a self-consciousness that 
understood history as always fundamentally split between events and their reconstruction in texts. ${ }^{7}$ History, historia, was never either onedimensional or strictly progressive or regressive, but rather, always partial and plural, a registry of multiple, even antithetical movements and events. The massive textual apparatus that accompanied most editions of the classical historians into print in the late humanist age testifies to the period's recognition that "writing from history," repeating the past as a pious textual act, was not an argument in favor of stabilization or stasis, but represented, rather, the opportunity for interruption, complication, innovation, and change. Such richness and diversity of historical sensibility and historiographical textuality were of course neither new nor original with Lohenstein in the mid-seventeenth century; late medieval and Renaissance historians, political theorists, and poets had been concerned with defining and legitimating their own indebtedness to antiquity in such a way as to be able also to assert their independence from it since at least the fourteenth century, if not before. ${ }^{8}$ The genres of historiography that existed by the time of the seventeenth century were legion, and each reproduced the past in the present in a specific way. The Sophonisbe prologue addresses the effects of this variety in a covert, yet resonant way.

It is ironic that Lohenstein begins the dedicatory prologue of Sophonisbe (244-52, 11. 1-276), a play whose matter is in large part derived from stories of the Second Punic War by classical historians such as Livy, Dio Cassius, and Appian, by seeming to suggest that the Moderns, his contemporaries, need to look to sources other than ancient ones for models, claiming that his "Spiel" (play; 245, 1. 19) both embodies and presents for analysis one of the fundamental principles not of history but of Nature ("Ist der Natur ihr Werck nicht selbst ein stetig Spiel?" [Is Nature not herself a continuous play?] (1. 25). Strangely at odds with the classical content of the play, Lohenstein's subsequent argument goes on to explicate the thesis that Nature, rather than historical texts or the Ancients, provides the best witness to the principle that interests him so much here. Disputing the talents of the ancient artist, Zeuxis (246, 11. 5566), for example, Lohenstein offers in the prologue case after case of the superiority of the decorations of stones and insect markings, the variety of fruits, and the beauty of flowers. In these products, Nature proves herself a better producer of artifice than the Ancients, better than Zeuxis or even, ironically, Quintilian, the traditional source upon which Lohenstein must rely for the Zeuxis tale. Both are pinnacles of ancient achievement, yet at this point, clearly inferior rivals to Nature in art.

Textual indicators of imitation and reliance on classical paradigms, 
such as the indirect allusion to Quintilian here, of course reveal Lohenstein's awareness that neither he nor the Moderns could really dispense with the Ancients completely. Elsewhere he describes the origins of religious rituals in ancient drama and the accomplishments of the classical tragedians $(250-51,11.211-70)$. Yet the point he appears to want to make is that even these explicit examples from antiquity function not as proof of the need to rely on the past but, rather, as evidence of man's "universal" need for ceremonies celebrating divinity, for example, or marking death; indeed, the best model for his very topic, namely, the "play" or mobility of the world in general is to be found, he asserts, not in texts, but in the "natural" phenomenon of the ages of man: "Für allen aber ist der Mensch ein Spiel der Zeit" (Man is above all a play of time/ time's plaything) $(246,1.73) .{ }^{9}$

Yet, precisely in the moment of his catalog of the ages of man that would have had the most resonance in the context of the play, given its origin in the pedagogical arena of the humanistic Gymnasium, namely at the end of the section on the schooling of the young with its reference to "das verhaßte Hauß/das man die Schule nennet" (that hateful place that is called school) $(247,1.92)$, Lohenstein's apparently antihumanist assertion that the realia of Nature and human life offer better evidence than the texts of the Ancients of the soundness of his thesis about "play" is revealed as susceptible to a double reading. The rejection of the Ancients is not as absolute as it might initially seem. The wisest man, Lohenstein declares, is not one who boasts of being schooled in and master of all knowledge, but, rather, the one who feigns. He writes:

Wiewol auch derer viel/die ihnen bilden ein:

$\mathrm{Daß}$ sie das beste Spiel gefaßter Künste machen;

Daß sie der Weißheit Hertz/der Klugheit Meister seyn /

Mit ihrer Gauckeley sind würdig zu verlachen.

Wer niemals thöricht spielt/die Klugheit oft verstellt/

Aus Thorheit Vortheil macht/ist Meister in der Welt.

(There are of course many who imagine that

They perform the best as masters of the arts;

That they are courageous and wise, shrewder than the rest.

But they deserve no more than scorn for their airs.

For he never plays the fool who masks his competence;

He'll master all by acting the clown.)

The claim here that feigning ignorance is often wiser than displaying wisdom is not marked in any way as derived from an ancient source; no 
references in the notes expand upon or decorate this passage with historical exempla or ancient myth. Apparently derived, then, from present "reality," from the register of schoolboy survival tactics, as well as from the Machiavellian discourse of political savvy, ${ }^{10}$ the Syndikus and former student at the Gymnasium, Lohenstein, appears merely to offer a word of worldly wise but simple advice based on experience: Never let on how much you know, and you will avoid both accusations of treason and being called upon in class.

As would have been obvious, however, to any student of Roman history - as both Lohenstein and the schoolboys of Breslau's MagdalenenGymnasium surely were-the indirect reference and masked textual source for this description of the advantages of playing the fool was the story of the Roman hero, Lucius Junius Brutus, who, as Livy tells it, "ex industria factus ad imitationem stultitiae" (pretended to be a half wit) as a means of protecting himself from the murderous intentions and criminal behavior of the "lawless and tyrannical Tarquin." 11 This was the same Brutus, of course, who ultimately threw off his mask of stupidity to avenge the rape of the Roman matron, Lucretia, by Tarquin, and called for the rebellion of the Roman nobility against the tyrant, thereby bringing the period of monarchical government in Rome to an end. While Lohenstein's appeal to strategic common sense may thus appear on one level to be derived from the Schulalltag (daily life in the schools), as well as from the discourse of political pragmatism, underneath the text's surface, it is the schoolboys' relation to Roman models of political behavior that is at stake, a relation that also depends on being able to recognize the textual wink in the direction of Brutus.

The masked call to imitate Lucius Brutus reveals, first of all, the political complexities of historical imitation, for, even though he "imitates" (imitationem), he is of course the "original" Brutus whose actions Marcus Brutus, the slayer of Julius Caesar, much later explicitly attempted to repeat in his act of "heroic" tyrannicide. Precisely this murder, the assassination of Caesar, ultimately demonstrated that history can never be structured as replication, for it led not to the preservation or extension of the republic over the body of the dead woman, but to its reorganization as empire over the dead male body with the coming to power of Octavian, Augustus Caesar..$^{12}$ The implications of even covertly advocating that the Moderns, here, the schoolboys, follow either the earlier or the later example by reproducing a past of political murder in the present of Lohenstein's immediate context on the eastern edges of the Empire would have been weighty ones indeed; the example reeks of possible treason, in fact. The learned detective work involved in recog- 
nizing the citation thus coincides with a call to mask one's political allegiances. The philological sleight of hand (that is, the absence of commentary) that Lohenstein uses to obscure the reference in turn mimics Lucius Brutus's own strategy of disguise and deception, indicating how difficult, even potentially dangerous it was to engage in either a politics or a historiography of imitation at the time.

Left out, then, yet also unmistakably implicit in the covert reference to Lucius Brutus's act as Lohenstein frames it is the issue of its essential nonreproducibility by Marcus Brutus. The difference between the specific contexts and ideological implications of their two actions marks the relationship between Lucius's dissimulation and Marcus's imitation as a Spiel, as signifying the kind of change and mobility in events of world historical significance that Lohenstein maintains in the prologue is the essence of "play." Lucius's mock idiocy was itself but the first step along the fraught path to a troubled position of power in his accession to the status of consul, a step that proceeded, via the victimization of Lucretia, to the founding of the republic. Yet, this (for some) clearly exemplary act was followed by the ambiguous development of Brutus having to watch as his own sons were executed for monarchical backsliding. This much celebrated, tragic disturbance of the homosocial principle of political inheritance was surely visible to and potentially quite unsettling for the young actors listening to the prologue of their play. In the longer, indeed "deeper" history of this passage in Lohenstein's play lie captured, then, the various moments of Rome's rise to power, its various forms of government established, contested, overthrown, and erected again. There is nothing monolithic about this Rome or its position as a reference point for the play. The message of Lohenstein's Sophonisbe is in turn as densely layered as the Spiel embedded in the prologue here.

The non-oneness of this moment of the Sophonisbe prologue, with Lohenstein's "subterranean" reference to Brutus inserted hard upon the claim to be able to do without, even to transcend ancient models, calls attention, I would argue, to the difficulty of reproducing history in this period at another, somewhat more literal textual level as well. ${ }^{13}$ In its status as an indirect appeal to classical history, the allusion to Brutus also underscores the multidimensionality of the historiographical tradition as it was available to the early modern present in a critical-philological sense. Any edition of Livy that Lohenstein might have used as a source for either the Brutus story or, indeed, for his play about Sophonisbe would have contained references to both other versions of the story and philological variants in the text. In editions like the one prepared by 
Johann Gronovius, for example, Titi Livii Historiarum Quod Extat, originally published in Amsterdam in 1643 and reissued in 1664-65, the passage that contains the reference to Brutus's feigned idiocy $(1: 56)$ would have called attention to the non-oneness of history in some of the following ways. ${ }^{14}$

Gronovius's edition of Livy is a complex and "noisy" text. His elaborate annotations are printed in two columns at the bottom of the page; in their typographical density, they often compete for the reader's attention with the Livy text above. Indeed, they are often so lengthy as to force the reader to turn the page to finish reading the note; the narrative of "history" must be abandoned to pursue the narrative of "deviant" annotative detail. One column of notes contains commentary by both ancient historians and modern editors about the events discussed in the text; these are the "Notae Variorum," and they are referenced by superscripted numerals in the main text. The other column contains Gronovius's own annotations and corrections ("Notae Gronovii"), which are referenced by superscripted letters that, like the numerals, clutter the main text above. The numerous glosses interrupt and fragment the story that is Livy's history of Rome time and again, insistently challenging it from various perspectives, some historical, some paleographical, and some philological. The density of Gronovius's Livy mirrors the thickness of Lohenstein's Brutus reference but, here, in a literal, visible way.

Gronovius indicates, moreover, in his notes on the line in which Livy first mentions Brutus that the sources dispute the "great liberator"'s family lineage; Dionysius of Halicarnassus, the Greek historian of Rome, he writes, claims that Brutus's mother was the king's aunt, not his sister, as Livy states. ${ }^{15}$ Included in Gronovius's learned marginalia is the text of the explanation of the correctness of Dionysius's version as penned by Heinrich Glareanus, the Swiss humanist and historian, who had written annotations on Livy in $1540 .{ }^{16}$ If the question not only of accurate family trees, but also of exactly which Roman history is the correct one and how the reader might recognize it is already raised by the very arrangement of the main text and the notes in Gronovius's Livy, then the reference to multiple editions and learned commentaries confirms that the reproduction of the past was not necessarily an easy task as far as early modern access to the master texts of Roman history was concerned. It is no wonder that Lohenstein's own historiographic project in Sophonisbe was easily as complex as Gronovius's Livy, since its annotational density rivaled the latter's in diversity and detail.

Diversity and plurality also characterized the texts of history at a more visible philological level in Gronovius's edition. Several lines later, for example, when Livy explains that the Spiel of the future "liberator ... 
populi Romani" led to his being known by the cognomen, Brutus, which literally means "lacking reason" (hence, "brute"), the main Latin text is again interrupted by reference to a note below, in which Gronovius calls attention to an alternate reading of the Latin verb "opperiretur" (to wait for), namely "aperiretur" (to reveal one's character), used in this passage from Livy; the latter makes more sense in the description of Brutus's "game." Gronovius does not give the source for the alternate reading or form of the verb, however, although he does note that other possibilities are offered in unidentified manuscripts ("Mss. fere operiretur"). In spite of these precedents, the rendering that he asserts is the most correct and thus the one he chooses to reproduce nevertheless is and will remain "opperiretur." Derived from the famous edition of Livy by Beatus Rhenanus, published in 1535, this version was, of course, original not with Rhenanus, Gronovius notes, but with two other humanist scholars, whose readings of Livy had so pleased him (Rhenanus) that his "mouth watered" (salivam movet Rhenani) and he imitated them..${ }^{17}$ Gronovius goes on to cite several additional cases of classical usage to support this unlikely reading, and then the pedantic note ends, but not before the reader is left wondering not only about the sexual relations of Brutus's background but also about his textual origins in multiple postclassical editions of Livy. ${ }^{18}$

The smoke screen of philological correctness in Gronovius's Livy functions in such a way as to allow the late humanist scholar (1611-71) to affiliate himself with an august community of earlier Renaissance editors, but also to differentiate himself from them in the production of castigationes, corrections of a canonical historiographical text. His "corrections" succeed, however, only in complicating (if not contaminating) the "original" text rather than in rendering it "chaste." The details of the textual history of Livy's History of Rome present in the margins of an edition such as the one by Gronovius make it clear that the version of the past over which the early modern present disposed in fact had its origins not in that past but in the present, as a highly contested and nonunitary textual "reconstruction" of ancient events. ${ }^{19}$ Lohenstein would have been confronted with this same hybridity every time he turned to nearly any edition of Livy he would have had before him as he wrote. The work of humanist critics and editors, designed to return ad fontes, and to restore ancient texts to their "true" and "pure" forms, in fact achieved precisely the opposite in cases such as this one, which demonstrates the ultimate distance, even inaccessibility, of the past to the here and now. The distance between the Ancients and the Moderns that Lohenstein's prologue produces in its mediated reference to Brutus replicates, then, the gap displayed in an edition like Gronovius's between 
the "events of history" and their reproduction in texts, a gap itself reproduced in the fashioning of a play based on, but radically other than, its historical sources.

The fact that Brutus could not (re)appear in either Gronovius's Livy or Lohenstein's play in any singular, immediate, or unadorned fashion as a classical paragon of political prudence or virtue to be imitated by the schoolboys calls attention, finally, to the political dissonance of the hidden example - its inappropriateness, that is, to the early modern imperial context of the play, namely the marriage of Emperor Leopold I to Margareta Theresia of Spain in 1666, following hard upon the victory of Vienna over the Turks in 1664. The union is celebrated at the end of act 2 of Sophonisbe in a masquelike allegorical interlude. ${ }^{20}$ The first Brutus was, after all, a destroyer of kings and thus implicitly of monarchical political structures; he would thus not be a good model for the Breslau schoolboys, if their schooling was to prepare them for positions in the state apparatus of early modern absolutism. His namesake, Marcus Brutus, was in turn also often represented as an agent of political sedition in royalist political theory in the Renaissance; the question of whether he "acted justly in murdering Caesar was a frequent topic in humanist pedagogical debates." ${ }^{21}$ The masking of the Brutus allusion, yet the very aptness of its application to Lohenstein's play points to the ambiguity associated with its potential to model political behavior. The problematic implications of reproducing the past in the present nevertheless cannot be contained once they have been released into the intertextual space of Lohenstein's text. To call for the "transfer [of] political virtue" directly "through time" 22 would effectively mean that time would have to stand still; under such conditions, political systems do not change. Lohenstein's prologue goes to great lengths, however, to explain that Nature would not permit such political stasis to occur. Yet, to suggest that the specific kind of political change indicated here in the reference to Brutus was in fact necessary, or even inevitable, would have been terribly ambiguous as a form of wisdom to offer to the young charges at one or the other of Breslau's elite schools. Like the historical accretion of learned commentary that accompanied the main texts of ancient history into their early modern published forms, the subversive power of Lohenstein's reference to Brutus in the citation is everywhere present, albeit at a latent level, in the text in which it appears.

There is something quite complicated, then, about the submerged reference in the Sophonisbe prologue to Brutus's behavior and to its relevance for the debate about relying on the replication of the past of the ancient world to provide models either for present political behavior or for historiographical writing during (early) modern times. Thomas 
Greene argues with reference to Petrarch's allusions to ancient locations, events, and texts that such texts clearly rely on the reader's ability to recognize the covertly present intertext and, as a result of this recognition, to be confronted with the difficulty of measuring the contemporary world against the world of the text. ${ }^{23}$ The complexity of the reference that fills the gap between Lohenstein's refusal of the Ancients and the presence of the Brutus subtext figures the non-oneness of the philological tradition that produced editions not just of his story but of all political deployments of the Roman past in this age. A similar concept of historiographical hybridity organizes both the rest of the text of Sophonisbe and the character whose name the play bears. This hybridity is initially most clearly discernible in the split text of her gender, which is foregrounded both in this and in other texts in which she appears. Her splitness is, of course, "bodied forth" in the material conditions of the plays' being acted by boys; but it also characterizes the very textual work of history and of the history play in general in this period as part of the pedagogical project in which they engaged. Sophonisbe's hybridity both in the play and in the tradition goes a long way in explaining the complex ideological program of Lohenstein's text.

\section{Playing with Gender: Sexual/Textual Cross-Dressing}

The non-oneness of the historiographical tradition upon which early modern reproductions of classical political scenarios relied informs both Lohenstein's Sophonisbe and the complexly gendered textual and dramatic identity of the character whose name the play bears. For sometimes obvious, sometimes more recondite reasons, her hybridity is particularly apparent in the remarkable number of scenes of cross-dressing in the play, four in the course of the first three acts. These scenes have received little attention in the scholarship, except to be noted as the textual residue of the Greek romance tradition, in which misrecognition and disguise were used to heighten narrative tension and to complicate and thus prolong textual and sexual adventures alike. Yet, particularly because they appear (or have been made to appear) to be only minimally necessary for the plot, these scenes of on-stage transvestism stand out, in Carlo Ginzburg's terms, as details in search of significance. ${ }^{24}$ Sophonisbe inherits an image of the Numidian queen derived from the Roman histories of Livy and Appian as well as from the histories of the Punic Wars by Silius Italicus, Dio Cassius, and others, yet is also at odds with that inheritance in a number of ways. The origins of her "oddity" begin to become visible in the cross-dressing scenes. 
The first exchange of clothing and thus the splitting of gender identity occurs early in the play when, in act 1 , Sophonisbe, preparing to defend the Numidian city of Cyrtha against Roman attack, dons military garb and instructs Vermina, the son of her first husband, the African Syphax, to dress as a woman $(270-71,11.346-50,375-80)$ so that together they can perform sacrifices to the gods of their city to protect Africa from defeat. Appeals to Amazonian precedent-she would be "Afrikens Penthasilea" (Africa's Penthasilia) (271, 1. 365)-appear to suggest that Sophonisbe's cross-dressing here belongs to a recognizable discourse of female militarism, a discourse that itself of course critiqued the notion of stable distinctions between the sexes in often unsettling ways. ${ }^{25} \mathrm{But}$ it is the actual exchange of clothing between mother and son that receives Lohenstein's commentary in his notes and thus draws our attention.

In the notes to this scene, the playwright references numerous ancient and contemporary sources, motivating the scene of stage transvestism by citing, for example, John Selden's De Diis Syris and Athanasius Kircher's Oedipus Aegyptiacus to confirm that such practices did in fact exist (357-58, 11. 152-76). According to the notes, the Ancients, in order to commemorate the mythological bisexuality of Venus, required the presence of both men and women for the performance of certain rites: "daß bey den Alten Venus und der Mohnde einerley/beyde auch Männund Weibliches Geschlechts gewesen sey" (for the Ancients, Venus and the moon were the same; they were also bisexual) $(357,11.155-$ 56). The onstage exchange of clothing called for in the play thus seems to have been designed to authenticate the representation of the Numidians as other, barbaric, and pagan, both in their politics and their rites. The scene culminates in what must have been an oddly exciting, yet terrifying dramaturgic ratification of this accuracy for the young actors, when Sophonisbe prepares to sacrifice one of her two younger sons upon a burning altar to the local Numidian gods in the interest of preserving the city from foreign invasion $(270-72,11.358-435)$. The boy is rescued at the last minute from the death that he, a miniature patriot, follows his mother in desiring, and two Roman prisoners are substituted, disemboweled on stage, according to the play as script (11. 473-500). The interest of the notes in the scene's "authenticity" is underscored by the excessive stage action here. The apparent illogic of the necessity to cross-dress in fact only causes it to stand out even more, however, since, in terms of the protocols of priestly attire that the queen - and the notes - describe, Vermina and Sophonisbe could have maintained sartorial identities appropriate to their "original" biological sex and still fulfilled the requirements for simultaneous male and female 
presence at the rites. Why the emphasis here on the surface exchange of their gender identities in the midst of a scene already so bizarre as to make the moment of transvestism almost superfluous?

Somewhat later in the play, at the beginning of act 2, Syphax, resolutely anti-Roman to the end, orders Vermina to undress, to take off his mother's female garb, and to redress, this time as a Roman (1l. 36-37). So disguised, Vermina will be able to escape capture by Massinissa, the African general who has himself become split, "Romanized" enough, that is, to be fighting on the side of the Romans. The boy thus becomes a boy and masculine again, two times over in fact, since when he sheds his female garb, he also sheds his African identity, coded as outlandish and feminine in the play, to become Roman and thus ostensibly rational and male. The details are intriguingly problematic, of course, since the young African becomes the exemplary future leader of colonial resistance even as he dons the enemy's attire. Vermina's return to his "true" gender here nevertheless calls attention to the original artifice of the play and, just as important, to the gap between the actual events of the classical past (the Punic Wars) and their reproduction on the Breslau stage. The boy playing Vermina would have been returning to his early modern "self" when he shed his staged sex, returning to "origins" that the boy playing Sophonisbe clearly could not yet reveal. In parallel fashion, the students in Breslau could not have either openly resisted their Romans, the Habsburgs, nor could they have refused to do their history lessons in school.

A closer examination of the final two examples of cross-dressing in Lohenstein's Sophonisbe, both undertaken by the character of the African queen herself, begins to reveal the significance of the various characters' multiple gender identities as well as of the gap between the history that the play allegedly represents and its reproduction on the Breslau stage. Still attired in her armor when a triumphant Massinissa arrives on stage in act 2 to claim Cyrtha for Rome, Sophonisbe is so well disguised that even though she is standing before him, Massinissa cries: "Sucht nebst Verminen auf die stoltze Königin/Die diesen Brand gebohrn. Die schleppt in Kercker ein!" (Hunt down Vermina and the proud queen who gave the firebrand his birth. Lock her in the dungeon!) (280, 11. 73-74). Sophonisbe then identifies herself to him as the queen whom he seeks, to which he responds: "Was? Ist dis eine Magd/die Helm und Harnisch trägt?" (What? Is this a maid who goes armed, with helmet and all?) (1. 78). The question is not at all a rhetorical one, however, because it assumes an answer not of certainty about gender distinctions but, rather, one of ambiguity and confusion. For it is by this very beautiful and proud Sophonisbe (and by a boy playing a female character 
dressed in male garb) that Massinissa declares himself erotically "besigt" (overwhelmed, conquered) by the end of this very same scene (282, 1. 159), a scene in which Sophonisbe, in a gesture of almost virile (Roman) virtue, asks him to kill her and her children rather than allow her and her royal offspring, as Numidians of rank, to be captured by "barbarian" Rome (281, 11. 114-30). Cleopatra's desire not to be paraded about Rome as the booty of Augustus finds a precedent here.

Sophonisbe's gender identity becomes as ideologically split in this scene as her acts of cross-dressing imply; she is a boy actor playing a female character dressed as a man, but also is, even in her display of virtue, an erotically powerful and hence feminized "passionate" African, who is nevertheless capable of acting in a courageous, nearly Roman fashion to preserve the honor of her house and line. The implications of this confused set of models for the lessons the schoolboy actors were to be learning are several. They could either imitate, indeed, be seduced by the African Sophonisbe's provocative and rebellious female character, here submerged, masked by her "masculine" armor. Or they could strive to take on her identity as a civic (albeit oppositional) patriot, marked by that very same dress. In both cases, the female side of her character is occluded, yet still clearly visible behind her male role. The difficulties of (re)producing the past, so obvious in both the historiographical source texts upon which the play was based and in the reality of the boy actor cross-dressing to play the African queen in the first place, are thus emphasized, even additionally complicated by the dual political positions associated with her character, rebellious colonial female, on the one hand, courageous (male-identified) patriotic rebel, on the other. That these dualities are important to the play is indicated by Lohenstein's invention of multiple scenes in which she doubles her dress.

The complexity of Sophonisbe's character and the difficulty of having the schoolboys produce a version of history on stage that appears to sympathize as much with the Africans as with Rome is confirmed in the final scene of cross-dressing in act 2 of the play, when the queen appears in male clothing one final time, now dressed as a "Römisch KriegsKnecht" (Roman mercenary) (285, 1. 259). So disguised, she steals into the dungeon to free her first husband, the resolutely oppositional Syphax, jailed by the turncoat, Massinissa, by exchanging clothes with him. Here, too, the gender inversion signals the fluidity of national and ideological identities between Roman and African as the "masculine" that is, patriotic, heroic, and faithful-side of Sophonisbe's character emerges. Massinissa, by this time passionately in love with the woman dressed as man, bursts into the dungeon in a rage driven by male rivalry fantasies to dispatch Syphax, who, unlike Massinissa, is an African true 
to the cause. He (Massinissa) is nevertheless mightily confused by the breast offered up to his sword. He asks: "Wie? hat der Syphax sich in eine Frau verstellt?" (What is this? Is that Syphax playing the female part?) $(287,1.322)$. The question and the onstage change of clothing that prompts it call attention one final time to the material conditions of the play's production, which itself demanded the "Verstellung" (alteration, disguise) of the boy actors' sex each time they undertook to act a female role. The scene goes on to infect both the spectator and reader, however, with the same doubt that plagues Massinissa, yet draws him irresistibly to Sophonisbe-namely, is it her "feminine" eroticism as a woman, so celebrated, yet also so deplored by ancient historians, or her loyalty to her city (represented here by the male military dress that she has donned, and masked as marital fidelity) that makes her so attractive as a character to Massinissa and, potentially and problematically, as a political model of resistance to Rome for the boys? Act 2 ends in an extended interlude (287-90, 11. 309-436) of wanton rhetoric combined with explicit gestures of erotic self-abandonment on the part of both Sophonisbe and Massinissa. The prospect of acting this scene as scripted may well have been the reason that permission to produce the play was initially denied by the authorities at Breslau. ${ }^{26}$

The scenes of cross-dressing in Lohenstein's Sophonisbe give pause for several reasons. They cause us to question, first, what it actually was that was being represented on the school stage in Breslau in 1669; the existence of brief program notes, or descriptions (Szenare), which suggest that the play was performed in such a way as to follow the printed text almost exactly, does not aid us, for example, in explaining how such extravagant scenes would have been produced on stage in 1669. ${ }^{27}$ They also cause us to wonder about the models of political virtue being represented by and for the boys on stage. The elaborate notes that appeared in the first printed edition of the play indicate a third level of historiographical confusion, particularly as it condenses around issues of early modern gender norms. The references in the notes to the numerous sources upon which Lohenstein relied in composing his play initially seem to make the case more rather than less complex by pointing to a textual and also a pictorial tradition from which his version is radically different. Yet this tradition ultimately yields a clearer image of the play. That is, the motivating conceit of Sophonisbe appears to be the reenactment of a story reported in the classical sources, namely, the victory of ancient Rome over Africa, a scenario reproduced and recognizable, perhaps, in the Holy Roman Empire's defeat of the Turks and thus in the "fated" rise to power of the Habsburgs in Lohenstein's own time. And yet, if we look to contemporary editions of several of the classical texts 


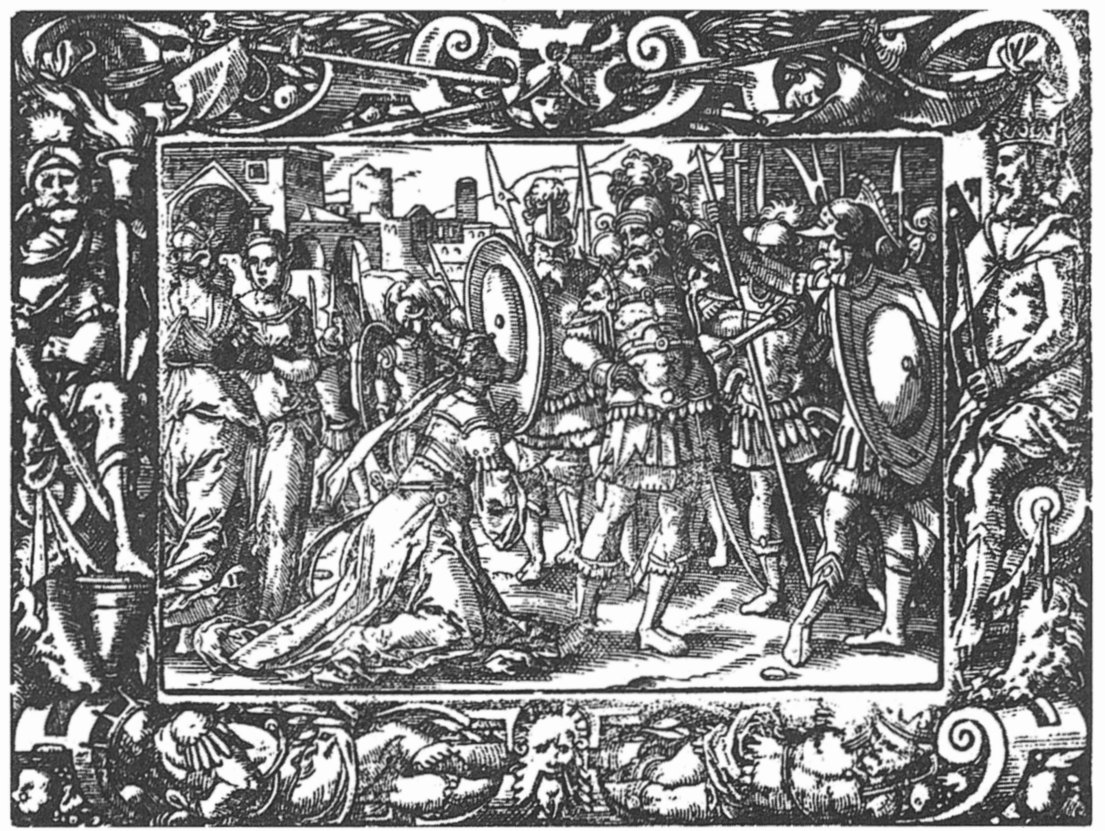

Figure 1. Titi Livii Patavini Romanae Historiae Principis Libros Omnes ... (Frankfurt, 1568), p. 354. Reproduced with permission of the Universitätsbibliothek, Tübingen, Germany.

that Lohenstein cites in his notes, we can discover a pattern of interventions in the way that those texts represent the Roman victory. This intervention occurs specifically in and as an inversion of its gender alignments and roles. It should come as no surprise that Lohenstein's Sophonisbe might have a somewhat different profile as a result and, thus, that the significance of the play both for the boys and in terms of its stance toward Vienna might well have been more ambiguous than it seems.

In his notes to the first scene of cross-dressing in act 2, Lohenstein cites two classical sources for the scene of Massinissa's triumphal entrance into Cyrtha, namely Livy's History of Rome and Appian's Punic Wars. Livy will be my primary object of investigation; the counterpoint of Appian's text is nevertheless also illustrative, and I return to it shortly. In Livy's history, it is Massinissa who appears dressed in armor at this point in the narrative. The emphasis on his military attire and profile as the Romans' colonial agent is only logical, since he has just come from battle. The "original" text actually emphasizes his appearance by placing Sophonisbe in the position of awed (and helpless) spectator. Livy 


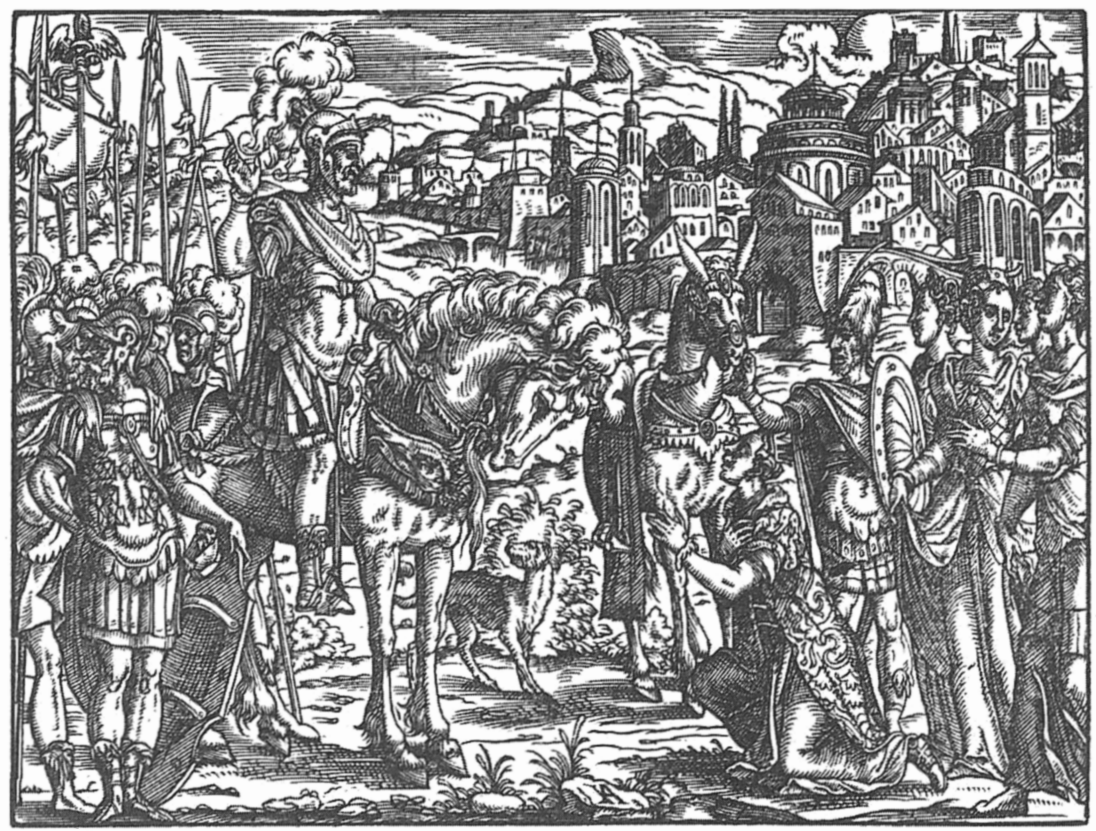

Figure 2. Titi Livii Patavini Romanae Historiae Principis Libros Omnes ... (Frankfurt, 1578), p. 547. Reproduced with permission of the Universitätsbibliothek, Tübingen, Germany.

writes: "[E]t quum in medio agmine armatorum Masinissam insignem, quum armis tum caetero habitu, conspexisset; regem esse (id quod erat) rata" (Sophonisba ... [saw] Masinissa surrounded by his horsemen and conspicuous amongst them by the splendour of his dress and arms). ${ }^{28}$ This contrast between the male general and the female queen was accurately received and reproduced, indeed, even emphasized in additional ways in editions of Livy's history widely used at the time. In both the 1568 and 1578 editions of the Romanae Historiae Principis Libri Omnes published by Feyerabend in Frankfurt, for example, the scene is accompanied by elaborate illustrations that depict Sophonisbe in vaguely eastern feminine garb pleading with a very masculine, "Romanized" Massinissa (see Figures 1 and 2). In a German-language translation of Livy published in Straßburg in 1619, the scene is once again illustrated; although the image differs in details, the queen's identity as female and as subservient is never in doubt. Again, she is depicted as wearing a dress and pleading for mercy at the hands of an exceedingly masculinized Massinissa. The title page of the first printed edition of Lohenstein's play in 1680 features an illustration designed by Matthias Rauchmüller 


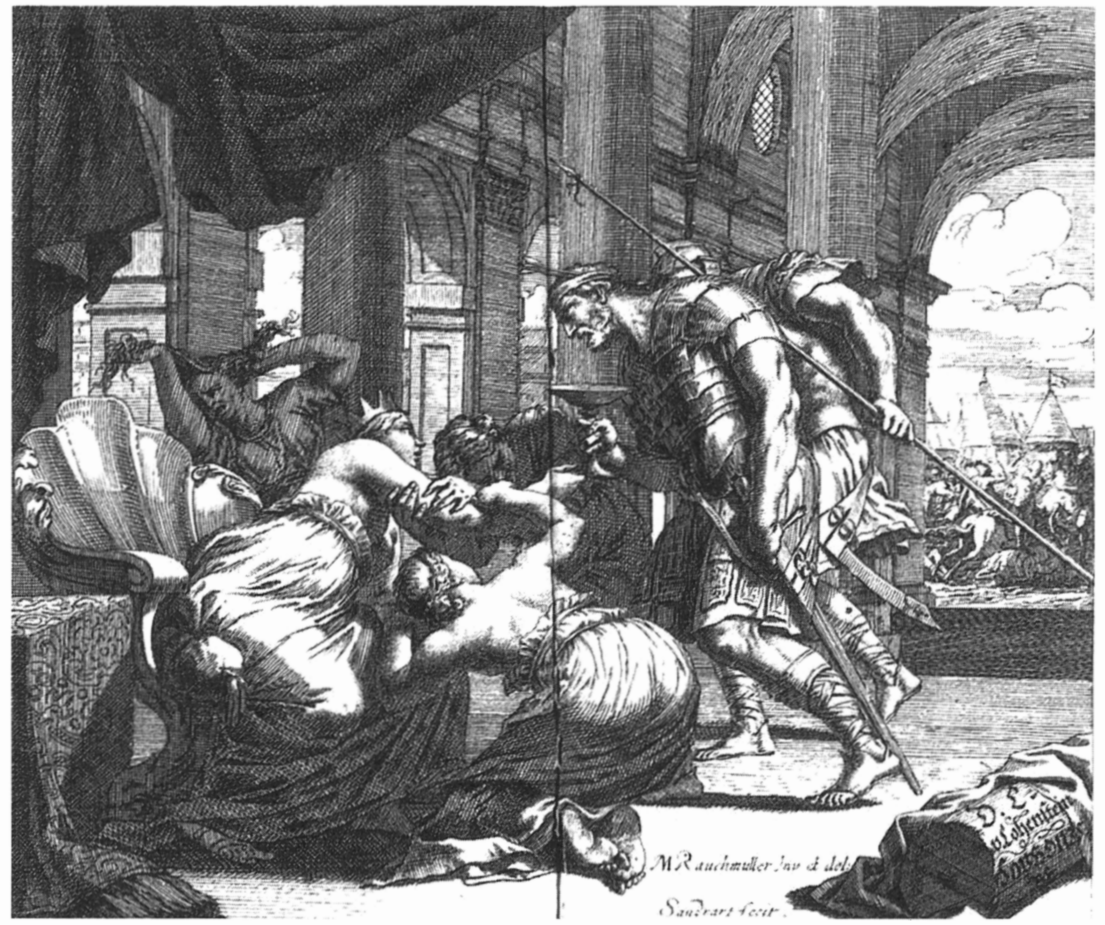

Figure 3. Lohenstein, Sophonisbe (1680). Reproduced with permission of the Bayerische Staatsbibliothek, Munich, Germany.

and executed by Joachim Sandrart, which, while depicting not this but a later scene in the play, sustains the visual tradition of a feminized Sophonisbe by dressing the queen in women's clothing as well as by endowing her with physical attributes that underscore her exotic female eroticism as the source of Massinissa's attentions in unmistakable ways (see Figure 3).

Lohenstein, of course, chooses to alter the gender alignments in this scene. In his play, it is Sophonisbe who appears in armor rather than Massinissa. Her costume could be understood to be motivated by the demands of the interpolated religious rites described earlier. Nevertheless, the distance of his text from its source in Livy and from the pictorial tradition in particular is striking. Other versions of the Sophonisba story had already followed the ancient historian in underscoring her identity as a woman in this scene. Lohenstein's deviation thus takes on a higher resolution when contrasted with them. In Giovanni Boccaccio's text celebrating well known women, De mulieribus claris (Concerning fa- 
mous women) (1355), for example, Massinissa's entrance is described in the following way: "Cum eum intrantem vestibulum ultra alios armis insignem cerneret ut erat, regem auspicata" (Sophonisba saw him enter the atrium more distinguished in armour than the others and realized he was the king). ${ }^{29}$ Boccaccio is following Livy here. Lohenstein clearly goes a different route by dressing the woman instead of the man in the garb of war. The very distinct inversion of gender roles that appears here, with Sophonisbe in armor and Massinissa overcome by feminized and feminizing lust, makes clear the distance between Lohenstein's play and its historiographical "originals." The gap between the play and its sources indicates that there was something about Livy's history of Rome-indeed, perhaps about the reproduction of Roman history writ large - that made it difficult to reenact in the context of the early modern German-language school play.

Lohenstein's reversal of roles in this and other scenes of cross-dressing in his play calls attention, then, to the difference of his text from one of its primary classical sources and thus to questions at the heart of early modern historiographical and also pedagogical debates: did or could history "repeat itself"? Could the Moderns learn from the Ancients and, if so, by what textual means? The material remains of Renaissance and early modern historical philology register a variety of answers to these questions by indicating that even as the ancient world became, in effect, ever more directly accessible in the form of numerous editions of its texts, it ultimately receded into an ever more complex and distant past, the exact nature of which was rendered impossibly obscure by the multiple versions in which it was made available over the years. Yet this obscurity was in fact productive, because it made room for and gave rise to ever more reproductions of the past. Again, a good example is the Livy edition published by Johann Gronovius in Amsterdam in 1664-65, which figures at the level of learned text work the layered complexity, the generic heterogeneity, and also the incredible fecundity of all manner of historiographical textuality at the time.

If we look in Gronovius's Livy at the source passage for the scene in Lohenstein's Sophonisbe in which the queen first appears to Massinissa in male garb, we find the page yet again cluttered by multiple references to a long tradition of Livy commentary and debate. ${ }^{30}$ Sophonisbe concludes her impassioned speech begging not to be made a prisoner of Rome: "neque me in cujusquam Romani superbum ac crudele arbitrium venire sinas" ([D]o not suffer me to be subjected to the haughty and cruel decision of any Roman). In the midst of this speech, the very speech that causes Lohenstein's Massinissa to be overcome with desire, the pedantic Gronovius interrupts with an explanation of his decision to re- 
tain the "pronoun" (presumably the "me"), which the famous Beatus Rhenanus had eliminated "for no reason"-_"Frustra pronomen exigit Rhenanus" - in his edition of 1535. Gronovius calls to witness in support of his editorial decision "Vossianus" (Gerhard Johannes Vossius, 1577-1649) and "Gall. omnes" (all the French) who "revocant" (recall) the pronoun in their editions. As the main narrative moves on to depict Sophonisbe clinging to Massinissa's knees in a heartrending manner, "itaque quum modo dextram amplectens" (thus entwining her right arm around him), Gronovius breaks in again with a lengthy note on the grammatical variances of the text at the point where her gesture is described. He offers that the reading of the Italian Carolus Sigonius, who had produced three successive editions of Livy between 1555 and 1562, in fact differs from his own ("Sigonius: cum diu dextram"). ${ }^{31}$ There are nevertheless many ways, Gronovius muses, to explain why Livy might have formulated the sentence in this terse way, and he (Gronovius) chooses to differ from the famous Sigonius. The reader is thus quite literally prevented from pursuing the gripping scene to its conclusion by the intervention of these and other learned editorial voices, amassed here, it would seem, less to enrich our understanding of its seductive pathos, than to register the complexity of the multiple encrustations of philological and grammatical debates that had developed around this passage over the years.

Throughout this episode as Livy describes it, Gronovius documents his agreement and differences with Rhenanus, Vossi(an)us, and others, both specifically and in general. In one note, he refers to the "priscae editiones" (ancient editions) he has consulted, in another to the "Vet[eri] lib.[ri]" (old books) of his research. ${ }^{32}$ These volumes would have included one or several of the folio Livy editions published by Feyerabend in Frankfurt in 1568 and 1578 mentioned earlier, which specifically included commentaries by Sigonius and Rhenanus, or editions and commentaries by Vossius and several French scholars as well. More compact editions, such as Janus Gruter's, also published in Frankfurt in 1619 , did not contain the more famous of the humanist annotations but, rather, only the "largely derivative" notes of Wilhelm Godelevaeus, originally published in $1568 .{ }^{33}$ Gronovius in any case does not cite Godelevaeus; a simpler edition such as Gruter's is thus not likely to have served as a source. The battery of references and learned skirmishes taking place in the margins of Gronovius's Livy thus suggests that its editor was familiar with a large selection of the many editions of the text available at the time in both Latin and the vernacular. Gronovius may have thought that he was offering a "new" and "purer" Livy to his public; but the material reality of his edition was that it appeared more "contaminated" than most. 
To my knowledge, there have been no conjectures made about which edition of Livy Lohenstein used as his source for the scene of Massinissa's first encounter with the Numidian queen. But it seems plausible, against the background of the other heavily annotated editions that he used of similar texts (editions that I discuss in chapters 2 and 3), that he must have referred to one quite a bit like Gronovius's rather than, say, to one of the simple "pocket" editions also published in Amsterdam in 1633 and 1635, which contained just the Latin text and no annotations. And had he used an annotated edition like Gronovius's, published, of course, at approximately the same time he was writing his play, it would have been clear to the German playwright that the past was as little present to him in its "original" purity in the books with which he surrounded himself as it had been to the German-Dutch professor, librarian, and polyhistor Gronovius, who was also seeking to reproduce a Roman past. Rather, Rome and its history of victories and defeats were almost irretrievably distant, conflicted, and "not one." Its "origins" had been the object of ongoing editorial work and sometimes bitter dispute at least since the editio princeps of Livy by Giovanni Andrea Bussi, published in Rome in 1469, if not before. Livy was consulted, Burke claims, in the early modern period, as a "counselor of policy" and as a source of "military counsel"; his text was considered a model of eloquence and a compendium of moral instruction. ${ }^{34}$ The number of editions printed during this period - some eighty-three before 1700 - testifies to this profound admiration. But the debates being conducted in the margins of a volume like Gronovius's (as it had been conducted, sometimes with rather more vehemence, in earlier volumes too) indicate the wide range of disagreements over the form his Roman history should take. The idiosyncracies of Lohenstein's play, which, upon closer examination, reveal a text engaged in manipulations of tradition, capture these historiographical debates as moments of gender inversion.

The characterological non-oneness of the German Sophonisbe, figured in the first scene of cross-dressing as an inversion of the "original" scene as Livy described it, results from another form of textual complexity as well; this complexity is present in other renditions of the Sophonisbe story, such as Boccaccio's, that Lohenstein clearly knew. As in the case of the oblique reference to Brutus in the prologue, these narratives about the African queen occur at a submerged level in Lohenstein's play. Their centrality to understanding her significance nevertheless emerges clearly in one apparently marginal scene in the final act of the play. This scene and its origins in a parallel tradition of hybridized histories of both Rome and of North African "Others" help explain the divided nature of Lohenstein's queen, which becomes visible in both the scenes of cross-dressing and the differences of the German drama from 
its source in Livy. If number and length are any indication, moreover, these texts rivaled "standard" accounts of Sophonisbe in the fascination they held for the early modern age. The "subterranean" existence in Lohenstein's notes of this alternative textual tradition of powerful women again reflects ambiguously on the very issue of history's reproducibility, on the capacity of Rome to "live again" in any number of genres, and on the applicability of classical paradigms to those areas of the Holy Roman Empire of the German Nation where women might be rulers and boys played female roles.

\section{Dido, Sophonisbe, and the Philological (Re)Production of Gender}

The splitness of Sophonisbe's character in Lohenstein's play is best represented, I have argued, by the scenes in which she dons male dress: first, her exchange of clothes with her son, Vermina; second, her "seductive" encounter with Massinissa; and third, her exchange of clothes with her first husband, Syphax, in order to secure his escape from the Romans, a scene that nevertheless culminates in the highly charged erotic exchange between a still cross-dressed Sophonisbe and Massinissa. In each of these cases, the gender ambiguity of the character points to a moment of ideological and moral confusion. Sophonisbe's hybridity of identity as both a man and a woman poses the question: is she acting in a masculine or feminine way when she participates in outrageous, intemperate, perhaps even superfluous scenes of sacrificial violence and seductive play? Moreover these very scenes also invest her with the profiles of a dedicated patriot and, in at least one scene, pragmatic politician, and, not least, loyal wife. The political nature of the gender ideology associated with her character in the play in each of these categories is not an irrelevant one, given the context in which the play was produced.

It would seem that Sophonisbe's identity as "lustful," female, and African marks those sides of her character as the ones to be avoided, overcome, and subdued in the young actors performing the play; like Massinissa, they were to acknowledge their "true colors" by turning away from political and social positions of minority to step into their places within the bureaucracy of the early modern empire, state, or city, leaving the passions of childhood and un-Roman primitivism behind. Certainly this is the Sophonisbe on which criticism has dwelled, prompted, perhaps, by the Sophonisbe of book 17 of Dio Cassius's Roman History, the source, it would appear, for all subsequent characterizations of the 
Numidian queen as a bedevillingly erotic enchantress, a woman and a

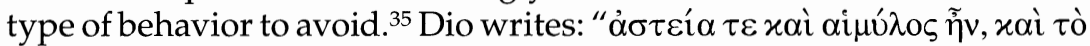

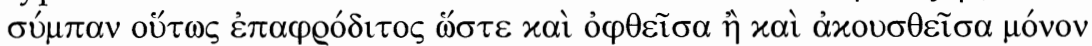

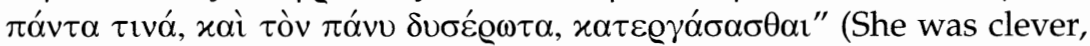
ingratiating, and altogether so charming that the mere sight of her or even the sound of her voice sufficed to vanquish everyone, even the most indifferent). ${ }^{36}$ In this scenario, it is the queen's male counterpart, who, when seen from the perspective of Roman history, represents the ideological success story of these events - the African, Massinissa, turns from the "oriental," passionate, and thus feminine values signaled by his self-abandonment to Sophonisbe's duplicitous charms in the final lascivious scene in act 2 to the Roman, rational, male values represented by his submission to Scipio's Roman authority in act 4 - and thus seems to function as the exemplary figure in the play. In this reading, history would repeat itself, as Lohenstein appears to have the quite remarkable Ghost of Dido predict will be the case in her lengthy prophecy in act 5 , and the triumph of Rome over Africa would be read as a prefiguration of the future glory of the Holy Roman Empire in Lohenstein's time. The boys could thus follow Massinissa's lead in good conscience. Dido's long and completely anomalous speech in act $5(335-38,11.77-188)$ lays out a "Roman" history that, with strategic emphases and elisions, leads directly from her own prehistorical, legendary defeat to Sophonisbe's own, and then onto the triumphs of Emperor Leopold in Lohenstein's own time. To become part of this narrative, the schoolboys would have to learn to reenact in their offstage political lives the allegory of Hercules at the Crossroads depicted at the end of act 4 (327-33, 11. 509-626). In this moment of (national, even ethnic) self-denial that involves denying Sophonisbe as well, Massinissa could be said to model for the boys the possibility of positioning themselves to defeat Rome's and the Holy Roman Empire's adversaries. In such a scenario, the African Massinissa becomes, oddly enough, the model Roman hero.

Yet it is precisely the juxtaposition of Lohenstein's Sophonisbe to that other "African" queen, Dido, here and elsewhere in the play and its notes, that elicits political ambiguities not unlike those expressed in her appearance in the early parts of the play attired in masculine, military garb. The linking of Sophonisbe with Dido locates the Numidian queen in a textual tradition that challenges both the notion of Massinissa's exemplarity and the traditional gender and ideological associations that the play would appear to be working so hard to produce. Precisely by introducing this tradition in the person of Dido's Ghost, Lohenstein makes it difficult not to see the legitimacy of Sophonisbe's rather than Massinissa's position, a position that, precisely by means of juxtaposi- 
tion with Dido, rejects the perverse casting of the Carthaginian queen as a mouthpiece of Rome. In the end, Lohenstein's Sophonisbe resists being turned into Rome's altera, or "other," as had happened to the figure of Dido in Virgil's Aeneid. The way in which Lohenstein's text highlights the existence of a different pre- if not anti-Virgilian Dido suggests, moreover, that his Sophonisbe picks up where this alternative Dido left off. ${ }^{37}$

When the Ghost of Dido is introduced into Lohenstein's play at the beginning of act 5 , her function would seem to be to bridge the gap between the history of the Ancients and the "modern" political realities of Lohenstein's world. Her appearance to the soon-to-be-suicidal Sophonisbe in the temple of Baaltis, to which Sophonisbe retreats in defeat $(333-34,11.1-31)$, appears to ratify the contract represented by the appeal to the Roman historical context and its source documents, namely histories such as Dio's and Livy's, in the first place: abjure everything the temple represents - women, the East, its gods, and its rituals - as well as the erotic side of yourself; reproduce the "heroic" actions of (at least half-) Roman figures like Massinissa (as well as those of "true" Romans like Scipio); and the new Rome, the Holy Roman Empire, will fulfill the promise of the old. The Ghost of Dido promises this future to both Sophonisbe and the audience at Breslau in a lengthy prophecy. She foretells the defeat of Africa and the triumphs of Rome, and then charts the transfer of ancient Roman authority over time to its Holy Roman descendants; the transfer culminates in Leopold's defeat of the Turks (11. 76-188). On the surface at least, the Ghost of Dido serves as the vehicle of a message about historical continuity and reproducibility; ancient Rome's superiority will revisit the earth in early modern, Holy Roman guise. ${ }^{38}$

However, to anyone familiar with the major literary documents of Latinity, such as Virgil's Aeneid, as Lohenstein's many references in his notes to the epic, as well as to Servius's commentary on Virgil, to Macrobius's Saturnalia, and to Nascimbenius's Virgil edition, published in 1577 , indicate that he was, Dido's appearance here as a prophetess of Rome's dynastic future would seem grotesque indeed, as split, in many ways, as Lohenstein's Sophonisbe is when she appears on stage in male dress, as distant, moreover, from "history" as the early modern editions of Roman historiography that Lohenstein could have used indicated they were from the "original" texts. For insofar as she is the voice of a Roman literary tradition of dynastic prophecy, Lohenstein's Dido promotes an ideology of empire at whose origins her own literal (Virgilian) and textual defeat lay. Positioning her as its publicist only underscores the constructedness of this image and, in turn, the constructedness of her appearance in the Aeneid in the first place, where, love-struck, she is 
forced to attempt to distract Aeneas from his divinely ordained mission of founding Rome, and then made to give way to the greater force of Rome's imperial destiny by being abandoned by Aeneas and almost entirely written out of the narrative after book 4. Virgil's Dido varied greatly from the established historical tradition of a strong and patriotic Dido, a tradition that preceded him and which knew "only a chaste Dido, [whose] history had nothing to do with Aeneas or the founding of Rome." ${ }^{39}$ Lohenstein was clearly familiar with this tradition, as his text and the notes show.

This alternative Dido, so little known to us today because of the obscurity in which Virgil's rewriting eventually left her, led a textually "healthy life up through the sixteenth century," according to Mary Louise Lord. ${ }^{40}$ She was "remarkable" for many reasons, including "fortitude, leadership, and craft." 41 She did kill herself; Virgil reports this accurately. But her suicide was neither an act of desperation and disappointment at Aeneas's departure nor a symbol of Africa's defeat at Rome's hands. Rather, in this other tradition, Dido's suicide was a gesture of marital fidelity to her first husband, Sychaeus; one remembers Sophonisbe's loyalty to Syphax here. It is clear that Lohenstein knew this pre-Virgilian tradition, which had itself been heavily commented upon in the very commentaries by Servius, Macrobius, and others that he cites. Indeed, by placing his Ghost of Dido in the temple of Baaltis identified with the Carthaginian queen, the German playwright "activat[ed]" the "index" or "code" of this other version of her story in connection with the Numidian queen..$^{22}$ This same code is operative when the Ghost of Dido speaks to Sophonisbe, even when she speaks to her of defeat. Having elected to manipulate Dido's role in relation to Rome by making her a perverse prophetess of its victory as scripted in the Aeneid, Lohenstein's text nevertheless also makes the "hidden" countertradition of an exemplary Dido visible beneath the surface of the play.

In the prophecy interlude in act 5, Lohenstein's Dido participates, moreover, in a second, aithough related, textual lineage traditionally associated with men. Here too we begin to suspect that there is something both askew and in order in this text as it was produced by boys. The most famous representative of the dynastic prophecy tradition was the figure of Aeneas's father, Anchises, who, at the end of book 6 of the Aeneid, speaks of the future empire to his son, the reluctant founder of Rome. Lohenstein alludes in his notes to his borrowing of a section from Aeneid, book 6, at the opening of Dido's speech, thus suggesting the parallel himself (397, 11. 208-10). In the Aeneid, we must remember, Aeneas spends the first four books of the epic dallying in northern Africa at the court of none other than the Dido, who, in the Virgilian tradition, spe- 
cifically represents delay and all that threatens the fulfillment of his filial task of bringing the family gods to safety in their new home; in book 6. Aeneas hears from Anchises a prophecy about the future that he is to create. When she appears to ventriloquize Anchises in act 5, Lohenstein's Dido thus functions as a kind of textual transsexual, even as she betrays in the notes a past that would link her to her pre-Virgilian persona as a strong female leader. Sophonisbe's appearance in male garb in the German play thus simply evens out the balance of this intertextual exchange. The boy speaking Dido may well be able to identify with the "original" male prophet, Anchises; but, in so doing, he must also elide some of the negative aspects of two African queens.

There is still another parallel between Sophonisbe and Dido and another, yet also related tradition of prophecy that seems to contradict or at least to interrupt both the underlying homosociality of these texts and of Rome's narrative of victory and Africa's position of defeat. This other tradition is particularly significant in connection with representations of women rulers, who, like the pre-Virgilian Dido, inhabited the traditionally male positions of valor and fidelity indicated in Sophonisbe's costume when she cross-dresses. These are values distinctly at odds not only with what has been represented as the gender ideology conventional at the time but with the image of the erotic pagan that Sophonisbe in particular has been made out to be. Just as, if not more appropriate, that is, as the intertextual reference to Anchises's speech in Aeneid, book 6 is the prophetic curse uttered by Virgil's Dido at the end of Aeneid, book $4 .{ }^{43}$ In Virgil's epic, the nearly suicidal Dido predicts here a future of discord for the departing Aeneas and for the Roman Empire, for which he abandons Africa and herself, its queen. Aeneas's desertion of Dido paves the way for Massinissa's abandonment of Sophonisbe - his Dido - many years hence. In both cases, the women are made to appear in the narrative of Rome's rise to power as erotic distractions to the much greater political enterprise of securing the future of the (male-identified) state. In Virgil's text, Dido cries out to her gods:

[A]t bello audacis populi vexatus et armis, finibus extorris, complexu avolsus Iuli, auxilium imploret videatque indigna suorum funera; nec cum se sub leges pacis iniquae tradiderit, regno aut optata luce fruatur, sed cadat ante diem mediaque inhumantus harena.

Haec precor, hanc vocem extremam cum sanguine fundo.

Tum vos, o Tyrii, stirpem et genus omne futurum exercete odiis, cinerique haec mittite nostro munera. nullus amor populis nec foedera sunto. 
Exoriare aliquis nostris ex ossibus ultor, qui face Dardanios ferroque sequare colonos, nunc, olim, quocumque dabunt se tempore vires.

([L]et / him [Aeneas] suffer war and struggles with audacious / nations, and then - when banished from his borders / and torn from the embrace of Iulus--let him / beg aid and watch his people's shameful slaughter. . . Let him fall / before his time, unburied in the sand. ... These things I plead; these final words I pour / out of my blood. Then, Tyrians, hunt down / with hatred all his sons and race to come; / send this as offering unto my ashes.... / May an avenger rise up from my bones, one who will track with firebrand and sword / the Dardan settlers, now and in the future, / at any time that ways present themselves. $)^{44}$

David Quint understands Dido's curse here as a symptom of "an alternative history of resistance." 45 It calls the "ending" of the "epic ending" of the victory of Rome into question by predicting that Rome's victory, when seen from the stance of the future anterior, does not appear to have been as conclusive a victory as might have initially seemed to be the case. That is, while it may look at this point in the Aeneid as if Aeneas and Rome have left the distractions and dangers of Africa behind upon abandoning Dido and Carthage, the queen's prophetic curse indicates the future truth that an avenger, namely Hannibal, did "rise up from [her] bones" to "hunt down" future generations in Rome. Hannibal's campaigns in fact took place during the time of the Punic Wars, the time when the historical Sophonisba and Syphax and Vermina lived and fought. The presence of Dido's curse in Aeneid, book 4, a location to which Lohenstein refers explicitly five times in the notes to the Ghost of Dido's speech, thus challenges the elisions in the project of empire represented in Anchises's prophecy by calling attention to the countertext of African patriotism that accompanied and troubled Rome continuously in its rise. Hexter points out that, technically speaking, Dido's curse is inaccurate as prophecy, since Hannibal did not defeat Rome. But the ongoing resistance to the empire that coalesces around specifically female figures here, namely Dido and Sophonisbe, cannot be overlooked.

These two versions of prophecy-one male and a prediction of Rome's future glory, the other female and a prediction of patriotic re- 
sistance to the empire-thus coexist and coincide, jostling for visibility in the multidimensional textual space that the Ghost of Dido occupies in act 5 of Lohenstein's play. Lohenstein's Ghost of Dido and his Sophonisbe are united precisely in the countertradition of a cursing Dido, moreover, because the uttering of such a curse had been explicitly identified with the figure of Sophonisbe in a number of earlier texts. The presence of a tradition of female prophecy and oppositional leadership associated with Sophonisbe lies, once again, below the surface of Lohenstein's play in the intertextual sphere that surrounds the figure of Dido's Ghost.

In spite of its surface rewriting by both Virgil and Lohenstein, the subterranean presence of a chaste and resistant Dido is hard to forget once its existence is known, as it obviously was to Lohenstein and his time. The lively textual presence of a nontraditional, exemplary, even patriotic Sophonisbe in the tradition would have been equally difficult to overlook. The most likely historical source for such a figure was a text that Lohenstein in fact alludes to countless times in his notes, namely, Appian's Punic Wars (5.27-28). There, even though the Numidian queen is mentioned only briefly, she clearly appears primarily in the con-

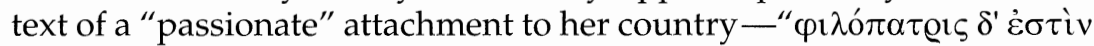

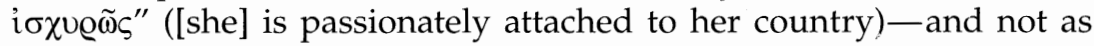
the embodiment of exoticism and lust. ${ }^{46}$ In subsequent versions of the Sophonisba story, circulating during the late medieval and Renaissance periods, the Numidian queen in fact quotes Virgil's Dido and her prediction of a troubled future for Rome, thus capitalizing textually on parallels articulated in Appian's characterization of her that had been put to less flattering uses in subsequent renderings of both women as guileful and unchaste.

In Petrarch's Latin epic, entitled Africa, written in 1338, and in his Triumph of Love, written together with the other Trionfi sometime after 1340, for example, we find Dido's prophetic curse placed in the mouth of her African sister at the point in the plot that coincides with the end of book 4 of the Aeneid, namely shortly after Massinissa abandons Sophonisba for Rome by sending her a goblet of poison to drink. In Petrarch's Africa, Sophonisba is described by her first husband, Syphax, and by the narrator in conventional terms of eroticized objectification; her neck is "a peerless, milk white column" (recto que sensim lactea tractu / surgebant), her eyes "twin stars in rival splendour gleaming" ([g]eminata superne / leniter aerii species inflectitur arcus), a "pure hue of lily in her cheeks" (candida purpureis imitantur floribus alme / lilia mixta gene), "her bosom's curve, exposed and softly swelling" (tum pectus apertum lene tumens) (11. 28-49; 11. 40-65). ${ }^{47}$ These are, however, 
clearly the projections of a male fantasy, husband's and narrator's alike, since, when left to herself, Petrarch's Sophonisba sits mourning not the absence of men or of sex, but, rather, the fall and dispersion of "her lands and [her] ... people" (sedens subiecta videbat regna sibi populosque vagos) (1l. 350-51; 11. 265-66). She in fact rejoices when she receives the poison from Massinissa, since it will allow her to "cast aside these fetters of the flesh" and rise up "to the stars" (sed sidera promptius alta, / terrenis ut eram vinclis exuta, petebam) (11. 957-58; 11. 73233), thus escaping potential ridicule at the hands of her captors.

Just before her death, however, Petrarch's Sophonisba quotes Virgil's Dido's prophetic curse in somewhat abbreviated form: "Victoria postquam / romano stat certa duci, nec flectere quisquam / fata potest eterna Iovis, / sint ultime vite / tristia, et eximiis sua Roma ingrata tropheis, / exul ut a patria deserto in rure senescat / solus et a fidis longe semotus amicis" ([A]s for the conqueror, may his last days of life be dark, may Rome / be thankless for the trophies he has won, / may he grow old far from his native land, / a lonely exile on a barren shore) (1l. 748-51; 11. 977-81). That she repeats the words of her Virgilian predecessor is difficult to overlook here. Oppositional to the end, Sophonisba is nevertheless not lustful or deceitful, but proud and devoted to her state.

This same noble, even nationalistic Sophonisba also appears in Petrarch's Triumph of Love, where she is shown, as in book 6 of the Africa, wandering together in the afterlife with Massinissa; we are surely meant to think of Dante's lovers, Paolo and Francesca, from Inferno, canto 5, yet perhaps also of the lonely and silent Dido of Aeneid, book 6. And yet, these lovers are different from Dante's, precisely because they do not share an erotic bond, nor is Sophonisba as silent as Virgil's Dido here. After listening not to a female complaint but to a male tale of passion and woe from Massinissa, the narrator of the Triumph turns to Sophonisba to hear her version. She answers curtly: "Costui certo per se gia non mi space, / ma ferma son d'odiarli tutti quanti" (This felowe pleased me nothing at all. / I am determined (ye and ever shall!) / To hate hym and all his nacion). She then issues Dido's curse in a similarly terse way: "S'Africa pianse, Italia non ne rise: / dimandatene pur l'istorie vostre" (Yf Africa wept, Italie had no nede / For to make bost of theyr lucky sped. / Aske those that your hystoryes do wryte / For they the trueth of both parties do endite). ${ }^{48}$ This Sophonisba knows that history is written by the victors, but refuses to recommend a version of her story that would reduce her to no more than an erotic object. She is resolutely true to her country and to herself as a representative of opposition to Rome, both in life and in death. 
The intertext of Virgil's cursing Dido in the dynastic Dido of Lohenstein's act 5 thus alerts us to the hidden presence of an unmentioned model and predecessor, to the existence, that is, of a Sophonisba like Petrarch's in the tradition, a figure in all likelihood based at least partially on Appian's patriotic African queen and heavily indebted to the preVirgilian Dido as well. This Sophonisba is a figure whose main attribute is her allegedly male sense of political and civic loyalty, a virtue commonly associated with Rome. Yet, she is as resolutely committed to her kingdom as Virgil's Dido was to Carthage; both produce strong counterimages of female power and of resistance to the empire and its march. We see this image echoed over and over again in Lohenstein's other plays. In his De mulieribus claris (Concerning famous women), Boccaccio echoes this tradition by representing his Sofonisba as a figure of almost Roman - and, indeed, almost male-proportions, and thus as a challenge for the empire's stranglehold grip on the ideology and imagery of loyalty to the state. She is courageous and politically pure; it is because she cannot bear to be given up "insolentia et fastidioso ... Romanorum arbitrio" (to the hateful and arrogant power of the Romans) ${ }^{49}$ that she willingly accepts the poison offered by Massinissa. She dies "nullo signo trepidationis" (fearlessly); suicide is, in her hands, "magnum et admirabile fuisset" (a great and admirable deed).$^{50}$ If this Sofonisba were in fact the Roman that her male garb in act 2 of Lohenstein's play suggests, we might even think of her as sister to Lucretia, whose death by suicide recaptured Rome's (here Africa's) purity and brought on Brutus's (self-)unmasking and foundational political act.

Reconstructing a history of literary texts in which Lohenstein's Sophonisbe finds a logical place allows us to locate what does not appear on the surface, yet is nevertheless present in the figurative margins of Lohenstein's text as the unmistakable intertextual matter of allusion. It also puts pressure on us to read more slowly for what is there in the margins, here in the massive endnotes, of Lohenstein's play, as well as in some of the less apparently logical developments in the plot. The Ghost of Dido appears to Sophonisbe in the temple of the sun and the moon in act 5 , for example, presumably the same temple to Cyrtha's native gods in which Sophonisbe had threatened to commit infanticide at the beginning of the play. The prophecy is issued in front of an altar that Sophonisbe claims Dido herself built. In his notes to this scene, Lohenstein reveals his knowledge of the pre-Virgilian Dido, who was specifically not the lusty widow so often remembered from Aeneid, book 4 , but rather the chaste goddess of Carthage described by, among others, the thirdcentury historian Justinus Frontinus, the same chaste goddess whose story Boccaccio and others tell. The notes tell her story as eloquently 
as if Petrarch's or Boccaccio's Sophonisba were there to speak on her behalf.

Lohenstein refers in several glosses to Justinus's rendering of a less Rome-identified history of the Carthaginians than Virgil's; highlighted is the historian's explanation of Dido's fidelity to her first husband, Sychaeus, the cause, in fact, of her suicide, when her people pressured her to remarry. Together with her political accomplishments, Dido's reputation for fidelity motivates her ultimate elevation to the status of "Göttin" (goddess) of the city. Alluding to Justinus, who used Servius, as well as the learned study of his contemporary, Samuel Bochart (15991667), De quaestione: Num Aeneas umquam fuerit in Italia? (Concerning the question: Was Aeneas ever in Italy?), Lohenstein dismisses the Aeneas "story" as a fiction and thereby aligns his Dido with her pre-Virgilian self. This move allows the reader to understand more fully Dido's references to herself not only as chaste and devoted to her "Eh-Herrns Geist" (husband's spirit) $(335,1.89)$, but also as explicitly male: "Elissa hat mit ihrem Leben/Ihr männlich Hertz nicht aufgegeben" (Elissa did not sacrifice her virile heart [courage] when she gave up her life) $(335,11.81-82)$, she cries. It may well have been this male courage and virtue, the virtu of the virago, Elissa, as embodied in Servius's, Justinus's, and Bochart's Didos, that enabled Lohenstein's Dido to speak Anchises's words of imperial prophecy while also bequeathing the Virgilian Dido's hatred of Rome to a "pure" Sophonisbe in turn. It may also explain the apparently incongruous gesture of marital fidelity in which Sophonisbe engages as she gives her first husband, Syphax, her clothes in act 2 to help him escape just before she passionately engages Massinissa in erotic play for over one hundred lines (287-90, 11. 309-436). Her apparent promiscuity functions as a cover for Syphax's temporary escape; in feigning her attraction to the turncoat Massinissa, she in fact adopts the loyal Dido's marital as well as her civic political code.

The intertext of a pure Dido helps explain, moreover, how just before receiving the poison from Massinissa in act 5, Lohenstein's Sophonisbe can refer to her own suicide and planned self-immolation in the following way: "So laßt/weil unsern Fall die Götter uns entdecken/Der Himmel ihn bestimmt/der Dido grosse That/Großmüttig ihr thun nach/ Burg/Tempel und die Stadt/In Brand/uns aufs Altar zu reinen Opfern setzen" (And since the gods reveal to me my own defeat that heaven has determined will be, let me follow the great Dido's example with courage and set fire to the city, this temple, and the castle while offering myself as a pure victim upon to them) (339, 11. 214-17, emphasis added). The flames will prevent her from being sullied by Roman hands (1l. 22526). As she drinks the poison, she cries: "Der sterbe nur/der nicht un- 
schimpflich leben kan!" (Only he must die, who cannot live purely!) $(346,1.464)$. Only the submerged presence of a chaste Dido, whose loyalty was, like Sophonisbe's, to Africa both as a geographical location and as the political stance embodied in Syphax's resilient opposition to Rome, could have produced this emphasis in Lohenstein's queen on purity and virtue. The suggestion that the schoolboy playing her might profitably consider the behavior of a woman ruler as exemplary is compactly reproduced in the use of the "generic" masculine pronoun ("der") to introduce this, one of Sophonisbe's final lines.

In one final twist of the intertextual inversions that comments upon the logic of a boy identifying with a brave and virtuous rather than lustful queen, Lohenstein's notes to act 5 refer explicitly (394, 11. 31 and 34, for example) to Silius Italicus's first-century C.E. Punic Wars, in which it is Hannibal who swears vengeance on Rome in a temple to Dido. ${ }^{51}$ That Dido takes the place of the cursing African male in Lohenstein's rendering of this scene confirms the ability of his male-identified and malerobed Numidian queen - and of the adolescent actor playing her role - to step in and also play the Carthaginian protagonist in the text in her role as African patriot. Dido's replacement of Hannibal both in the play in general and here in act 5 in particular signals, then, the gap between the convention of representing women and especially exotic African women only as "other" and unchaste, and the tradition in which she and the German Sophonisbe participate here, namely, a tradition of strong and, if need be, erotically active women leaders.

In its reliance on the source texts of Justinus Frontinus and Silius Italicus, as well as on Servius and Macrobius, Lohenstein's text makes present in the notes to the play the breadth and depth of a historiographical tradition that allowed him to look not just at a single text, such as Livy or even Appian as a source for the story of Sophonisbe, but at multiple and conflicting renderings of the same material. Out of this set of texts, he not only weaves an alternative image of both Dido and Sophonisbe, but also creates in his notes a multiplication of the perspectives from which Roman history can be seen. When we consider the editions in which Lohenstein would have known any or all of these texts, we can understand how and why such potentially unstable, even fractured, images of the past might have made sense. I have already noted the complexity of Gronovius's Livy. Lohenstein cites the equally dense sixteenth-century edition of Virgil by Nascimbenius mentioned earlier, an edition in which he must have had access to excerpts from Servius. He also appears to have used the Justinus edition of Matthias Bernegger (1582-1640), upon whose editions of other Roman authors he relied extensively for other plays. ${ }^{52}$ Prominent, finally, in Lohenstein's notes 
throughout the play, but particularly here at the beginning of act 5 , are references to texts such as Bochart's treatise on Aeneas, Christophorus Hendreich's De Respublica Carthaginensium (Concerning the Carthaginian Republic) (1664), and the enormous tomes by John Selden, Athanasius Kircher, and others on Egypt, Africa, and their common past in the greater Mediterranean basin, all of which Lohenstein relied upon over and over again.

Complex compilations of ethnography, geography, and history, texts like Hendreich's in particular provided many of the details that formed the dense network of references and counterreferences that filled Lohenstein's notes. Encyclopedic and eclectic, these volumes themselves replicated the archaeological depths of Rome as well as of its satellite colonies that the period was beginning to discover in enormous detail. Even though the title of his book is cited incorrectly by Lohenstein, Hendreich's text seems to have served the playwright particularly well in his development of some of the more excessive scenes of blood ritual in Sophonisbe. Lohenstein explains, for example, that his sources-Hendreich is named here-indicate the association of human sacrifice with the figure of Dido (394, 11.31 and 34); his Sophonisbe merely inherits the practice from Dido via Hendreich's text. But Hendreich dwells not only on the less tasteful elements of Carthaginian culture. He also takes care to note that to die for one's country, for example, was considered a privilege of the elite in Carthage..$^{53}$ The availability-and, indeed, popularity- of volumes such as this one serve as a learned counterpoint to and as the antitype of the heavily glossed editions of the Roman historians to which I have already drawn attention. The juxtaposition of Gronovius's Livy, for example, and Hendreich's tome of learned miscellany, including a forty-one page "syllabus" of the classical and contemporary authors he used in compiling it, captures neatly the density of the radially organized textual world, out of the margins of which Lohenstein's Sophonisbe - both the character and the play that bears her name-emerged.

\section{The Play That Is Not One}

The scenes in which Lohenstein's Sophonisbe appears dressed as a man are legitimate, then, insofar as her attire represents values such as fidelity and loyalty to the state (values conventionally coded as male). These values are nevertheless also explicitly associated with Dido (and thus, with African queens) in a tradition of available texts, many of which Lohenstein signals that he knew and used in his notes. The figure of 
Sophonisbe is related in this tradition to the cursing Dido of Aeneid, book 4; she is an unequivocally female figure, moreover, who is nevertheless also identified with a kind of "manly" devotion to the state. Sophonisbe's retreat in act 5 to the temple where the Ghost of Dido appears places her in direct proximity to the figure whom the city had chosen as its goddess, and makes it difficult to ignore the fact that it is Dido's identity as founder and defender of Carthage that is emphasized in the notes to the scene of cross-dressing in act 1 . This scene of course itself takes place in the same temple in which Sophonisbe dies, namely the scene of ritual sacrifice to Baalthis.

Using Bochart and Selden, Lohenstein points out in a lengthy gloss that Baalthis was a Syrian and Phoenician goddess who was here thought to have been "des Saturni Ehweib and der Venus Mutter" (Saturn's wife and the mother of Venus) $(358,11.202-22)$. The note also indicates that this is the same goddess to whom the Virgilian Dido is shown dedicating an altar in Aeneid, book 1. When we look at this point in Virgil's narrative, a point that precedes the "overwriting" of the queen's preexisting reputation by the events of book 4 , we find Dido in the midst of handing down laws, assigning tasks to her workers, being the very pious leader, in other words, whose reputation the rest of Virgil's text must go on to undermine and replace (11. 698-717). It is precisely this early Dido of Virgil's book 1, moreover, and not the defeated queen of book 4, with whom Lohenstein has his Scipio associate Sophonisbe, when he laments that Massinissa has chosen her as his coregent and wife: "Du mehr als edler Held! Wo hastu hingedacht? / Daß du ein Weib der Stadt/die sie zu Göttern macht/Zur Herrscherin erkiest!" (You, more than noble hero: What were you thinking of? You have chosen as your regent the very woman whom this city worships as a god!) (317, 11. 127-29). Lohenstein glosses this line with a reference to Aeneid, books 1 and 4, but he could just as well have cited Appian or Justinus or Hendreich on Carthage for models of the Dido who became Boccaccio's chaste and strong Dido, for example, the woman honored, according to Boccaccio, by her countrymen "nec tantum publice matris et regine loco, sed deitatis inclite eisque faventis assidue" (not only as their common mother and queen, but as their goddess, their protector) and revered "dum stetit Cartago, aris templisque excogitatis sacrificiis coluere" (with altars, temples, and sacrifices as long as Carthage stood"). ${ }^{54}$ This is the Dido whose reincarnation in Sophonisbe Lohenstein's Scipio correctly fears. Lurking in the notes and appearing in somewhat distorted, ghostly form, this Dido calls for the counterpart that she receives in the cross-dressed Sophonisbe of the German play.

The Ghost of Dido in act 5 of Lohenstein's Sophonisbe thus recalls both the dynastic Dido of the Aeneid's book 1 and the cursing Dido of the 
Aeneid's book 4; her presence interferes with a victory narrative predicated on the erasure of women that Virgil would have constructed for Rome. In Lohenstein's version, these same intertextual references intervene in Dido's Ghost's prediction of an easy supremacy for the inheritors of Rome's legacy in early modern times, for they recall a preVirgilian Dido whose image had to be mightily repressed in order for her defeat as scripted in the Aeneid to occur. Scholarly treatments to date have repressed alternative images of Sophonisbe in similar fashion. Reading the story told in Sophonisbe as one of the necessary casualties in the coming to power of the Holy Roman Empire, a narrative based on the legacy of classical Rome to which Vienna may have desired to lay claim especially at this time, suppresses key elements of Lohenstein's play and leaves unexamined some of its more untraditional elements and scenes. What assurances did the student actors of Lohenstein's play have, for example, that his Dido's description of the glory and prominence of "großmächtgen Stamme/Des Durchlauchtgen Oesterreichs" (the great and powerful house of his excellency, the emperor) (337, 1l. 153-54) would not be profoundly undercut by the passing of time, by the resistance of the Turks, about which they well knew, and by the general "play" (Spiel) of history invoked at the beginning of the text? The German Sophonisbe's complex gender identity indicates this "play," the unpredictability that is associated with all reproductions of history, both those registered in the myriad sources and textual traditions upon which Lohenstein relied in composing his text and those visible in the bodies of the actors on stage.

If the boy playing Sophonisbe in Breslau (and the others who watched him) recognized that Sophonisbe's patriotism was in some sense an expression of (Roman) virtue, but a virtue firmly displaced into the African, oppositional context, and that her character could thus be understood not as the "Schreck-Bild" (negative example) she is often made out to be, but as an instance of "ein großes Gemüt" (a great-hearted individual) not unlike Scipio Africanus, indeed, not unlike Augustus Caesar himself, 55 then the clear distinction between a superior Rome and a defeated Africa breaks down in the same way as the divisions between male and female and between past and present seemed to dissolve in the tradition of historical and literary texts to which Lohenstein referred. The triumph of Rome over Africa had not been unambiguous to begin with. Lohenstein's play shows that there were as many interpretations of exactly what that victory might have meant as there were ways of reproducing the history of Rome in the complex textual and political landscapes of early modern central Europe.

The character of Sophonisbe as Lohenstein constructs it and as we have access to it if we follow its philological trail into the notes of his 


\section{Sophonisbe}

play thus lies at the intersection of multiple traditions. The play's ambivalence about its protagonist has been read by critics since the seventeenth century as evidence of a confused and reckless personality typical of women and non-Christians. Yet the non-oneness of both her character and the text testifies less to Lohenstein's commitment to such reductive positions and more to the text's staging of the wide-ranging historiographical and pedagogical debates about reproducing the (models of the) past. The gap between the gender of his protagonist and that of the schoolboy playing her captures the difficulties of these debates on stage for all to see. 


\section{Sex "in Strange Places": Sexed Bodies and the Split Text of Lohenstein's Epicharis (1665)}

\section{Academic Bodies and the Early Modern (Fe)Male Subject}

In the previous chapter, I looked primarily at the ways in which textuality and sexuality can be read together in Lohenstein's Sophonisbe as two sides of a single historiographical issue-namely, the question of the reproducibility of the past in the present and of the necessary interventions and distortions that occur when the Ancients are construed as models in a radically different (early) modern age. The textual and sexual excesses present in Sophonisbe signal the gap between the play and both of the two inversely related versions of what it has been thought to be about: a facile confirmation of the ascendancy of Rome and its early modern imperial descendant, on the one hand, and the representation of Rome's aberrant Others in Africa and Woman, designed partially to titillate, perhaps, but ultimately to shock and dissuade, on the other. At precisely those moments when Sophonisbe's unorthodoxies cause readers and viewers to focus on them most closely, in horror as well as in bewitched fascination with her erotic power and impassioned commitment to her city and state, it is not the illegitimacy, but, rather, the legitimacy of her actions that comes into view in the mobile depths of the annotational apparatus of the play. Lohenstein's subtle text work and my own efforts to disinter it by means of "slow reading" thus collaborate to reveal an "untidy" and complex textual tradition in both the "main" text and its "margins," the variables of which interact in ways that refuse to stabilize along clean historiographical, philological, or gender lines.

I have also argued that in Lohenstein's play, the challenges of the text cannot be confined to the world of print in either its discursive or material forms. On stage, "bodies [also] matter" when they intersect with the textual world indexed at multiple levels in the notes. In 1669 one young boy mimed the actions of a feminized man, Massinissa, who, in both the sources and in the play, is "in libidinem pronus" (to lust inclined), while his classmate played the erotically active, yet heroic queen, Sophonisbe, who in this version of her story at least regularly cross-dresses to maintain a political profile traditionally associated with men. ${ }^{1}$ The boys and 


\section{Epicharis}

their characters thus both were and were not what they seemed, both "real" and differentially "sexed bodies" that depended on their differences to heighten the impact of much of the play, and ideologically disruptive images of feminine identity that may well have been more common in early modern texts than late-twentieth-century readers have learned to expect. Located at contentious intersections of these material and discursive worlds, both the text and its actors traveled promiscuously between them, attaching themselves to a variety of positions in Lohenstein's deep and complex world of literal and literary allusion.

I have argued that Lohenstein's Sophonisbe is involved in a complex relation to its historiographical sources. The case of Epicharis (1665) is also complex but in a somewhat different way, for its learned notes point explicitly not just to a difficult relation to gender but to the labile status of biologically sexed bodies in the early modern period as well. The relationship in Epicharis between the schoolboys of Breslau and the play's sources, in which the sexed bodies of women and men seem to trade places with ease, is the subject of this chapter. The plot of the play addresses the fate of the young freedwoman, Epicharis, who is said to have been involved in the Pisonian conspiracy against the emperor Nero in 65 C.E. The story of the conspiracy had been told many times in both classical and early modern texts. More often than not, the figure of the philosopher-playwright Seneca is highlighted in these retellings, showcased for his integrity as well as for his gruesome but heroic death as a result of his affiliation with the plot. But just as Lohenstein chooses Sophonisbe as his protagonist instead of the African general Hannibal in his play about the clash between Rome and its "other" in the Punic Wars, so too in Epicharis, he organizes his stage and text version of events associated with the implosion of the empire in later years specifically around a female protagonist less transparently available for the boys to imitate, one might think, than the figure of Seneca.

The classical sources tell us little about Epicharis, other than that she was involved in and died soon after the Pisonian plot was discovered, tortured to death at the hands of Nero's sadistic henchmen. Lohenstein develops a complex plot precisely around this cipher of a woman, who stands out in the German playwright's dramatic corpus as the sole female character worthy of unambiguous praise. Using both intertextual allusion and the notes, Lohenstein maps a densely constructed identity onto the figure of Epicharis that refuses, in a manner not unlike his Sophonisbe, to condense around a single biological or ideological center. Again, the role was clearly performed by a boy. Yet the play, both as script and as print text, is deliberately and pointedly obsessed with Epicharis's female body as an object not only of desire but also of tor- 


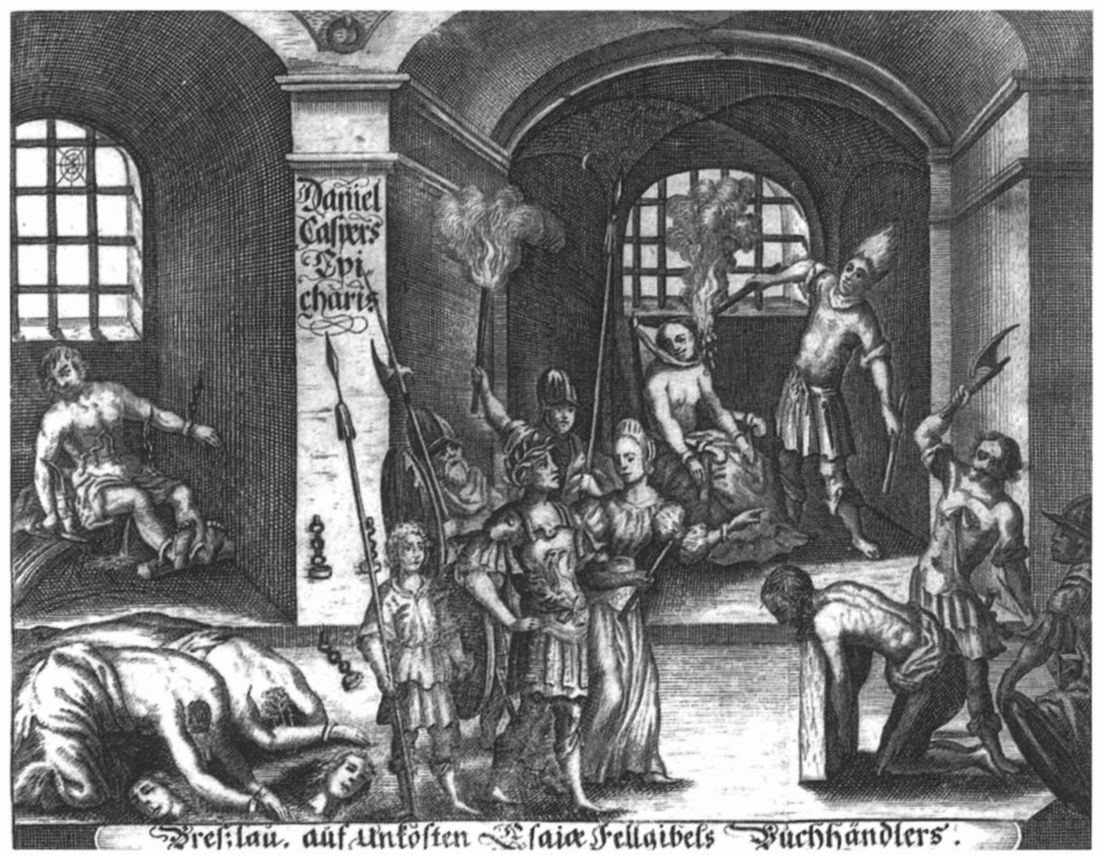

Figure 4. Lohenstein, Epicharis (1665). Reproduced with permission of the Bayerische Staatsbibliothek, Munich, Germany.

ment and abuse. The origins of Epicharis's dimorphic provenance in a rich textual tradition become visible precisely in the notes to the torture scenes, which in turn cause us to confront the reality of the play's location in the political-pedagogical realm of the schools. The frontispiece illustration of the first print version of Epicharis (Figure 4) provides an opportunity for commentary on the historical position of the text both in this context and as an object of study in our own critical world, particularly insofar as the literal sexed bodies of the early modern period are concerned.

The frontispiece of the 1665 text represents within a single frame what is in fact a composite of several scenes in acts 3,4, and 5. In this series of scenes, the conspirators are either tortured or executed (or, in the case of Seneca, forced to commit suicide) after Nero has discovered the plot. The illustration thus collapses into a single moment the beheading of Sulpitius Asper, for example, the execution of Lucan's mother, Atilla (probably in the foreground near the bottom of the scene), and Seneca's suicide. As full of horrors and perhaps also stage impossibilities as these 
scenes of sadistic treatment and abuse are in both the picture and the play, none shocks quite so much, however, as the one that focuses on the woman, Epicharis, represented here in the right center background of the image, seated in the alcove, elaborately bound. The details of her case, discussed later in this chapter, are excruciating. ${ }^{2}$ Indeed, as central as the figures of Nero and his vicious consort and companion, Sabina Poppaea, might initially appear to be to this image in a technical sense, the frontispiece to Epicharis, published with the first printed edition of the play in 1665 one year prior to its production, actually highlights the "secondary" event of the torture of Epicharis, who is literally in the background both here and, more figuratively speaking, in Tacitus's description of the Pisonian conspiracy as well. Like the frontispiece, the play, whose title appears on the column on the left in the image, ultimately displaces our attention onto the centrality of a specifically female body. The visual organization of figure placement in this image, its differential darkening and lightening of the various clusters, and its attention to anatomical detail all capture the play's focus on the woman as the subject of the action around her, in spite of her apparently marginal status in the parallel economies of the image and of traditional textual renderings of these events.

For those familiar with the tradition of stage productions of Lohenstein's school plays, however, as the baronial dedicatee of the play, Otto von Nostitz, provincial governor of Schweidnitz and Jauer, would have been, the construction of Epicharis's body as overtly female in the frontispiece image would have been problematic at best, given the material conditions of producing the play in the context of the all-male Breslau schools. The tension introduced by such local knowledge is productively heightened not only by the illustration but also in the annotated text of the play, which provides elaborate commentary on the gendered subject of the scene of torture in particular. The problem of the frontispiece-Is it a representation of a woman, or of a boy actor in drag?neatly foregrounds the impasse with which such a text confronts a gender criticism and approach that would focus exclusively on either women or men, for in the context of the image as a published illustration to a performed play, Epicharis is clearly both female and male. The image thus causes us to ask what was really the subject of the play. Was its project the deconstruction of female gender ideology in a misogynist age, or the construction of male gender codes designed to "civilize" the boys within the context of the schools? As critics and historians of gender in the early modern period, should we attend more to women or to men and boys? The impossible doubledness of the sexed body of Epicharis in the frontispiece offers a way to consider these questions anew. 
Much early feminist critical work on the early modern period addressed the status only of women's sexed bodies as they were multiply impacted, produced, and determined by a variety of discursive and material formations in a number of important ways. The fact that men were also subject to early modern gender ideologies and technologies of control was left underexamined during this early stage. ${ }^{3}$ The weighting of early modern gender studies in the direction of women can be traced back to the origins of much of this scholarship as either a direct or implied response to Joan Kelly's inaugural question in 1977, "Did Women Have a Renaissance?" Kelly's role in the crafting of a feminist Renaissance has become nearly mythic; her intervention in the 1970s was provoked by traditional historiography of the Renaissance that had either licensed itself to ignore gender entirely or innocently followed the "universalist" lead of scholars like Burckhardt, for example, who wrote in his The Civilization of the Renaissance in Italy (1860) that "to understand the higher forms of social intercourse in this period, we must keep before our minds the fact that women stood on a footing of perfect equality with men." ${ }^{4}$ Such receptions of Burckhardt as well as of Kelly's response that, precisely with respect to "higher forms of social intercourse," "women as a group ... experienced a contraction of social and personal options that men of their classes did not," and thus, that there "was no renaissance for women - at least, not during the Renaissance" 5 provoked two different kinds of responses from feminist scholars and historians.

Gender-conscious criticism of the 1980s built on Kelly's insights while also seeking to resist the "tragic" narrative and strategic silencing of women's voices inadvertently suggested by her invocation of a variety of social, economic, political, confessional, and ideological determinisms. ${ }^{6}$ On the one hand, a self-consciously and thus perhaps strategically "essentialist" focus on the actions of early modern "women's bodies" emerged. 7 Projects to collect and edit texts by and information about early modern women began to paint a somewhat less parochial picture of the Renaissance that women did in fact have; such research aimed at counteracting the potential effacement of the realities of women's literary and cultural production during this period with which studies concerned only with examining the objectifying and exclusionary gender ideology of the time might have colluded. Yet this approach remained partial precisely because of the difficulty of gaining access to "women's culture" in any "thick" way for sometimes preliterate or otherwise empirically less documented groups. The essays included in Hendricks and Parker's Women, "Race," and Writing in the Early Modern Period (1994) were among the first to attempt to interrupt the celebrationist critical narrative of an "other" (and yet still homogeneous) world of cul- 
tural production peopled by women by pointing to its constructedness in turn. At approximately the same time, Margaret Ferguson introduced the element of class to challenge methods of looking for women in ways that might essentialize. ${ }^{8}$

In a second kind of criticism, other scholars, including Marilyn Migiel and Juliana Schiesari, challenged the very project of exclusively "empirical research on women." 9 In the absence of any purely "mimetic" sources or representations of "women's experience," they called for the interrogation of the place of ideological gender in the canon (where are the texts written by women, and what image of the past does the present construct in representing cultural legacies as either a matter of gender or not?), including an assessment of "the political economy of gender," an investigation of the "societal and cultural norms governing gender and gender identities" not just in works by men but in cases that involved female-authored texts as well. ${ }^{10}$ For these critics, the "essential" Woman and the women writers of the early modern period are themselves considered the products of variously constructed political and social discourses and codes. In response to an earlier focus on the discursively and materially determined bodies of women as the producers of culture and to the previously excluded body of works that was their cultural production, scholars went on to develop a "hermeneutics of gender" that would interrogate the assumption (which in fact characterized Kelly's study) that texts and documents could function at all as "transparent media" or "transmitters" of these women's experience, rather than as ideological and rhetorical scripts by which feminine (although not necessarily female) subject positions were constituted. ${ }^{11}$ In this second set of approaches, the academic subject is less the individual or even the collective bodies of women per se than the construction of the category of Woman and its role in the political, economic, confessional, juridical, medical, and even typographical and publishing discourses of the period. ${ }^{12}$

As women's sexed bodies moved off center stage in critical debates about early modern gender systems, room was made for a study of the early modern construction of gender in a more global sense; the theoretical and methodological door was opened, so to speak, for the construction of male social and political gender to be examined in equally dense detail. Grafton and Jardine's From Humanism to the Humanities, a study of the material and ideological conditions of humanist male scholarship, was enriched by Richard Halpern's The Poetics of Primitive Accumulation, which assessed the role of early modern schooling in England in the production of male subjectivity. More recently, Barbara Correll's The End of Conduct underscored the centrality of the task of "civilizing" boys into adult male workers and public citizens in the early 
modern world. The need for approaches to the sex-gender systems of the early modern period of this third kind, which includes the study of the production of the male subject, is of course everywhere apparent, and nowhere more so than in analyses of the realm of the schools, as Halpern has shown. That texts and bodies coexisted and mutually constructed one another was a kind of first principle of early modern humanist pedagogy..$^{13}$ The analysis of the coincidence of the female characters of Lohenstein's dramatic protagonists with the male bodies of the schoolboys who produced them from precisely this location, as part of a study of early modern gender that includes the analysis of the ways in which male identity intersected with images of women, belongs to this third way. In a world in which, as Correll has formulated it so eloquently, Woman was the "repository of an ideology of identity constructing the sex-gender system of a patriarchal society," Lohenstein's plays about women were about both women and boys. ${ }^{14}$ In Epicharis, the focus on the torture of the woman calls attention to this coincidence of ideology and sexed bodies in complex ways.

A final dimension of the ambiguity of the early modern scene of pedagogy must be mentioned in the context of a discussion of how the boys' literal bodies interacted with the characters-both female and malewhose actions they mimed on the stage. There is fairly reliable documentation in the Szenare as well as in a contemporary school administrator's diary that Lohenstein's plays were produced as they were written and published, with no editing out of some of the more extravagant scenes such as the one depicting Epicharis's death. ${ }^{15}$ Lohenstein's Agrippina (1665), for example, which was produced in conjunction with Epicharis as the other specifically "Roman" play in 1666, calls for the enactment of the murder of the emperor Nero's mother, who exposes her breasts to receive the fatal blow; also included in Agrippina were moments of incestuous seduction and subsequent interludes of necrophiliac lust (see chapter 3). Again, there is no indication that these scenes, like the torture scenes in Epicharis, were not performed by the boys.

We may well want to consider the evidence that we have in light of whether such stage gestures would have caused any concern at the time. In the institutional review and reform of the Breslau schools in 1643, for example, the authorities acknowledged the necessity of providing a Protestant alternative to the very popular dramatic productions sponsored by the Jesuits, whose school in Breslau had begun to compete with the Protestant Gymnasien in 1638. ${ }^{16}$ And yet, as enthusiastic as the city council was about the need for the productions, the documents also display an overt concern for the possible consequences of the plays for both the morals and the professional education of the students of the Protestant schools. Permission for production was granted, but only for 
a limited number of days each year, and members of the council were known to attend rehearsals. Caution was urged to prevent interruptions in the boys' other schoolwork; the need for discipline was invoked in light of the possible (and otherwise unspecified) "Üppigkeit" (extravagance) and "anderm unordentlichen wesen" (other kinds of disorderly conduct) associated with the plays. ${ }^{17}$ Toward the end of the century, one local chronicler in fact mentions the productions, for which the boys were apparently "tipped" if the audience was pleased, as having both distracted the students from their "Studia" and led to "Excessen," the details of which the chronicler believes are best left undiscussed. ${ }^{18}$ Any number of reasons associated with these fears may have made it difficult for the boys to secure permission from the city council to produce plays after 1666, when Epicharis and Agrippina were performed; indeed, when they petitioned for the right to stage Sophonisbe in 1669, permission was initially denied. They were successful in securing a permit only after a second try. Even then, however, two inspectors were assigned to provide oversight.

Such official reactions regarding the need for restraint and control in the plays and of the boy players suggest that the 1666 productions of Agrippina and Epicharis were considered in some way extravagant. In the case of the former play, the origin of such concerns is clear. There, young men mimicked erotic scenes with their schoolmates in ways reminiscent of Sophonisbe's encounters with Massinissa. It is more difficult, however, to understand the call for the (re)production by the boys of the brave and selfless Epicharis as an object of intense civic anxiety - except perhaps for the fact that it was a woman whom the boys were explicitly being asked to emulate in traditional humanist fashion, and nowhere more so than in the scenes of torture in which her femaleness is underscored. Here, as in the case of Sophonisbe, but perhaps with even greater urgency, because the Numidian queen's exemplarity is visible only beneath the surface of that play, Epicharis's heroic nature precisely as a woman is the central focus of the plot and displayed for all to see. The question poses itself yet again: were the boys, future civil servants in the "sex-gender system of a patriarchal society" of which Correll writes, to imitate women rather than men? Indeed, if an unknown freedwoman could be as exemplary as the famous philosopher Seneca in resisting tyranny, what other kinds of class and political boundaries and borders could not be transgressed? Perhaps such issues were of concern to the city officials of Breslau too.

The dialectic of presence and absence of the boy actor in and from the woman's body in the Epicharis frontispiece thus captures the difficulty of studying ideologically "pure" gender formations in the early modern 
period in general and specifically within the political-pedagogical system of which Lohenstein's oeuvre was a part. Then, as now, pedagogical institutions, both textual and otherwise, played an important role in "managing" the (re)production of sexed subjects. The frontispiece reveals the complex ways in which the male civil subject in Breslau became embodied quite literally as an effect of print culture, on the one hand, and as the result of the material conditions of producing plays in which women functioned as the protagonists and title figures, on the other. The realm of the schools may thus have been a place where the male "puberty rites" of instruction in Latin and the classical tradition were enacted, as the boys mechanically shed any residual effeminacy to take their place as men in the world. But in Epicharis, as in other of Lohenstein's plays, the boys appear to have needed to learn how to be men by either themselves acting or interacting with classmates who played a "female part." In Epicharis, the infans, the one who cannot speak, is an adult woman, and her silence indicates not political immaturity but her steadfastness and ability to model political commitment and bravery. If this particular play is to be understood as part of an ideological and literal mechanism of schooling that would sculpt the gender identity of the early modern central European political subject and "his" place in the world, the methods of that pedagogical system would appear to have been far more complex than the simple critical narrative of either female heroism or inexorable masculinization has allowed.

\section{Sex "in Strange Places": Sexual and Textual Confusion}

In chapter 38 of book 17 of the Natural History, the Roman historian Pliny the Elder comments on the reign of the corrupt and degenerate emperor Nero. But he does so indirectly, his textual strategies mirroring techniques of survival in the Rome of rulers like Nero as well as Vespasian, under whom Pliny lived. Pliny takes as his ostensible topic the incidence of natural prodigies and portents. "Sunt prodigia et cum alienis locis enascuntur, ut in capitibus statuarum vel aris, et cum in arboribus ipsis alienae" (Another class of portent is when trees grow in strange places, as on the heads of statues or on altars, and when different [strange, or foreign, alienae] kinds of trees grow on trees themselves). ${ }^{19}$ He lists several examples of trees "in strange places," and then concludes:

[S]uper omnia quae umquam audita sunt erit prodigium in nostro aevo Neronis principis ruina factum in agro Marrucino, Vettii Mar- 
celli e primis equestris ordinis oliveto universo viam publicam transgresso arvisque inde e contrario in locum oliveti profectis.

(A portent that will eclipse all those ever heard of occurred in our own day in the territory of the Marrucini, at the fall of the emperor Nero: an olive grove belonging to a leading member of the equestrian order named Vettius Marcellus bodily crossed the public highway and the crops growing on the other side passed over in the opposite direction to take the place of the olive grove.)

Here Pliny's chapter abruptly ends. He seems to have known that his account of the botanical prodigy with which nature marked the death of the lecherous and cruel emperor in 68 c.E. would have needed no gloss for his first-century audience, because the transgressive spectacle in fact followed a clear historical logic by mimicking the corruption of Neronian Rome; there, flaunting disrespect of publicly acknowledged limits was a matter of course. The crossing over in which the grove engaged figured neatly the crisis of cultural, political, and moral values into which, according to Pliny, Nero's Rome had declined.

As logical as Pliny's chapter on trees in strange places was in the context of late imperial Rome, it might seem an odd place to look for commentary on the problem of "historicizing" the complexities of what has come to be known as the "sex-gender system," defined most effectively by Gayle Rubin as the process whereby biological difference (i.e., sex) becomes culturally coded as gender. ${ }^{20}$ "Natural," anatomical difference "makes no difference," Rubin's concept suggests, until it becomes inscribed in a gendered social structure that invests biological fact with values, functions, roles, and thus legislates its "legitimate" place in the order of culture. Rubin's definition here suggests that biology, or sex, is a stable quantity, and that only gender ideology fluctuates according to social context, political power, and economic need. Building on this apparent dichotomy and distinction, Joan Scott comments that "gender is ... a social category imposed on a sexed body"; the task of the historian of sex-gender systems, Scott continues, is to refuse "the fixed and permanent quality of the binary opposition ... of sexual difference" by analyzing the specific contexts of historical gender constructs as a means of discovering the logic behind specific placements of sex. ${ }^{21}$

Pliny's example underscores, however, the difficulty of maintaining such distinctions between the alleged stability of "nature" (sex) and the manipulations of culture (gender) in specific historical circumstances. Under Nero, for example, both sex differences and gender ideology often became as mobile as Pliny's trees. Indeed, sex in the most literal sense seems to have occurred regularly and publicly in and as transgression, 
in strange places, that is, and in strange forms, between mother and son, between effeminate emperor and male concubines, and between maleidentified emperor, finally, and feminized (i.e., castrated) boys. Gender roles were equally fluid, and nowhere more so than in a world in which even anatomical sex seems to have been subject to inversion, reversal, and change. It is no wonder that Lohenstein's play about Epicharis and the plot to assassinate Nero asks us to question both the distinctions between male and female gender identity and the easy exchangeability of men's and women's bodies - and body parts - as well.

The sexual transgressions of Nero's Rome were the object of great and peculiar fascination for Lohenstein. ${ }^{22}$ His texts and their author have themselves often been judged to be as unnatural as the events themselves, a false interpretive logic conflating the subject of the plays with both the playwright and the significance and value of his texts. But when critics become as fascinated with the eroticism of Lohenstein's dramas as they assume their author was, they overlook the fraught nature of both sex and gender in his plays where issues of eroticism are not concerned. Epicharis offers one of the best examples of the prodigious sexgender system of his dramatic corpus precisely because of the anomalous nature of the title figure, who distinguishes herself from her counterparts in Lohenstein's other plays as a woman who is not known for her sexual exploits. Rather, she is first and foremost a political agent.

The early modern period was of course obsessed with outlining the parameters of permissible behavior for biological men and women in countless treatises and laws, yet also fascinated with what we might call unnatural moments of slippage between both sexual identities and gender roles, with mystical androgynes and literal hermaphrodites, on the one hand, and Amazonian female rulers and cross-dressed sailors and soldiers, on the other. ${ }^{23}$ Both this legislative obsession and the interest in phenomena that exceeded its reach testify to the fragility and fluidity of both sexual identity and cultural codes at the time. Particularly vexing were the cases of women whose gender profiles provoked not suspicion or fear because of their powerful eroticism but, rather, undiluted admiration for bravery, constancy, and virtuous behavior. ${ }^{24}$ Lohenstein's Epicharis is just such a woman. It is not by chance, then, that the textual and sexual contraries of her "origins" emerge with particular force both at the play's very outset, where her biography is explored, and again in its final scenes, where Lohenstein's focus on the grisly details of her torture and death forces readers and spectators alike to confront the "naked truth" of her appealing identity head on. Epicharis may be read as an exploration of the relations between gender identity and sexed bodies in early modern central Europe, then, relations that were of great 


\section{Epicharis}

importance to the political and ideological culture of the schools. Although the character of Epicharis may seem at first glance "out of place" in this context, her anomalousness can be explained by considering her hybrid textual origins at these two locations in the play.

The text of Lohenstein's Epicharis first draws attention to the shifting nature of the protagonist's sex-gender profile at the level of story. In the most commonly acknowledged classical source for the play, namely book 15 of Tacitus's Annals, the Pisonian conspiracy to assassinate Nero in 65 C.E. is characterized as the undertaking of a cross section of senators, citizens, and military men. "Epicharis quaedam" (a certain Epicharis) is also involved. ${ }^{25}$ Although Tacitus contends that she lacked a reputation for honorable actions, he offers no further details of her background; he is not even clear how she learned about the plot. Lohenstein's Epicharis's identity is far more distinct and, yet, all the more evidently hybrid in a number of ways. In the incongruous speech detailing her life history at the opening of act 1 , for example, she narrates at length the complex tale of abandonment at birth followed by multiple adventures and intrigues, imprisonments and escapes (163-69, 11. 106322). Her supplied fictional heritage here is derived, as Spellerberg and Asmuth have shown, from the French gallant novel, Ariane, written by Jean Desmarets de Saint-Sorlin, published originally in 1632 and available in German since 1644. ${ }^{26}$ In Desmarets's novel, Epicharis's class origins are the subject of much attention. Not only does she figure as the maid, companion, and friend of the noble protagonists, but she is ultimately discovered to herself be of noble blood. Her class identity functions as a legitimating force in the plot against Nero. ${ }^{27}$ When Lohenstein's Epicharis relates her past adventures, then, she is telling a story not out of her Tacitean past, where she was in effect without a history, but rather one indebted to Desmarets's early modern text, which defines her more carefully by elevating her status and making her unambiguously female. The very attempts to supplement-and perhaps distinguish her from-her classical predecessor by lending depth and specificity to the cipher she is in Tacitus's text nevertheless ironically reveal Lohenstein's Epicharis to be without stable origins. For ultimately she is a composite of both classical texts, like Tacitus's, and early modern source texts like Desmarets's. As it turns out, this hybridity makes her quite different from her namesake in the French novel after all.

The differences between Lohenstein's Epicharis and her predecessors in Tacitus and Desmarets become most apparent in her show-stopping autobiography of act 1 at those points at which she refers to occasions when she has cross-dressed and adopted ideologically masculine poses (166-68, 11. 234-35, 259-60, 289-91). ${ }^{28}$ Donning male clothing only to 
aid friends or to escape danger, Desmarets's Epicharis tells of her experimentation with what was standard behavior in genres like the gallant novel and the Elizabethan comedy, in which female characters "pass[ed] through the stage of the man" to become women, demonstrating their fidelity and honor prior to revealing themselves as "really" female and thus capable of acquiescing to their "proper" place in the economy of heterosexual pairing. ${ }^{29}$ No exception to this model, Desmarets's Epicharis is ultimately revealed to be of noble birth, as indicated earlier, and escapes the confines of her "historical" death as reported by Tacitus by dismissing it as a rumor in order to marry Palamedes, the brother of the title figure. She thus comes to occupy a safely and clearly stable, female location by the end of the French text.

Lohenstein's Epicharis, however, identifies more strongly with the features associated with the male image of her Hosenrolle (breeches part) and denies the novelistic intertext and device of these particular textual origins even as she cites them. She declares that she will not leave off cross-dressing; rather, "[v]ermummt als ein Soldat" (disguised as a soldier) (181, 1. 733), she hopes to participate in the assassination attempt. Epicharis's rejection in Lohenstein's play of what is the traditionally transitory nature of female cross-dressing leads her, moreover, to reject the advances of Volusius Proculus at the opening of act 2. There, Proculus would penetrate through her disguise, both as the boy in whose clothes he first encountered her (cf. 168-69, 11. 289-310) and as a member of the lower class ("Es ist Epicharis aus knechtschem Stamme nicht" [Epicharis comes not from inferior stock]) $(185,1.38)$, to engage her in sex. Epicharis may maneuver her way out of his importuning by insisting on a feminized "Keuschheit" (chastity) $(186,1.79)$, but her real allegiance is to her costume and to the male-identified political role in the conspiracy against Nero that it implies. ${ }^{30}$ She boasts that her participation in the plot proves that women can engage in tyrannicide too (169, 1. 329), it is true. But the gender of Roman republican values is delineated as masculine throughout the play. Not only is Nero as effeminate as the lackeys with whom he surrounds himself $(178-79,11.616,669)$, but Proculus is characterized as politically unreliable precisely because he is "von der Zung ein Mann/ein Weib ... in der That" (talks a manly game, but is a woman in fact) $(169,1.342)$. Here Lohenstein follows the conventions of gender coding traditional in discussions of Roman virtue found in parts of the story as told by Tacitus (e.g., Annals 15.67 and 70 ). When and because she remains true to a male profile and the political cause it represents, Lohenstein's Epicharis's gender is at odds with Desmarets's character, whose autobiography she borrows. This "masculine" side brings her closer to her historical (i.e., Tacitean) counter- 
part, a similarity that in fact means that Lohenstein's heroine, like Tacitus's, must ultimately be tortured and die. It is a side of Epicharis upon which others, such as Boccaccio, also commented, when he wrote of the "manly fortitude" of her "brave spirit" (generosum ... animum ... virili robore) in his Concerning Famous Women. ${ }^{31}$

It is not by chance that Lohenstein's Epicharis differs from Desmarets's in relying on and remaining indebted to a masculine identity, since she was played by a boy actor in Breslau in 1666. Unlike other of Lohenstein's heroines, however, such as Sophonisbe, who appears at least on the surface to be a character to avoid, Epicharis is admirable, arguably the only figure in the play capable of modeling exemplary political behavior. And yet, she is female and thus a prodigy in this respect too, because she trespasses on so many of the characteristics associated with women at the time. Of particular importance is her ability to keep silent under torture..$^{32}$ Epicharis's rejection of stereotypical female garrulity, in fact, defines her in most other sources in which she is mentioned, sources Lohenstein would have known; I deal with the gender implications of his treatment of these sources later. The young actor playing her part may have felt more at ease with taking on the identity of this exceptional woman precisely on the basis of her rejection of one of the standard attributes of femininity and her inscription, instead, in a discourse of (political) virility. Only from a traditional standpoint, then, does the German Epicharis appear to be "in the wrong place" as a highly disciplined free woman involved in an all-male conspiracy organized by nobles. While the autobiographical interlude of act 1 , replete with its tales of cross-dressing, seems to interrupt the action of the play as "ein ausgesprochener Fremdkörper" (a clearly alien moment) and "artfremder Splitter" (intrinsically foreign fragment), as Asmuth has written, 33 it in fact calls attention to the "original" hybrid nature of both the character and the text.

\section{Staging Ambiguity: The Question of Epicharis's Tortured Body}

The confusion about Epicharis's origins reaches additional levels of complexity in the final scene of Lohenstein's play in which the title figure is subjected to brutal torture on stage. Here more clearly than in the narrated autobiographical interlude in act 1 , the vexed nature of the relationship between the sex of the boy actors and the gender identity of their roles becomes apparent in additional ways. A peculiar selfconsciousness about the artificiality of all of the categories invoked by 
the play marks the scene, for just before committing suicide in the ingenious way that Tacitus describes, Epicharis challenges her tormentor, Nero, with the taunt that she will be honored by future generations as a virtuous martyr, while he will be remembered only with disdain and disgust. She cries:

Ein Weib hat zu Athen: Daß dem Tyrannen sie Nach außgelachter Kwal die Zung ins Antlitz spie/ Ein ertzten Ehrenbild im Tempel ihr erworben: So/wenn Epicharis schon längst wird seyn gestorben/ Wird sich die Nachwelt ihr zu einem Tempel weihn Und ihr Gedächtnüs-Bild ein ewig Nahme seyn / Und wenn man mich und dich wird auf den Schauplatz heben/ Wird Nero nur durch Schmach/ich durch die Tugend leben ... Schau aber Blutthund her/hier in der Folter-binden Wird itzt Epicharis des Sterbens Hafen finden.

(There was an Athenian woman, who is honored in bronze; She responded with laughing disdain to her tormentor By spitting her tongue in his face.

So too will posterity erect a monument to Epicharis Long after she is gone;

It will serve as an eternal reminder of her name.

And when you and I, [Nero], become no more than strutting characters

On a stage: I will embody virtue, and you, only shame...

So look here, you blood hound, for it is here In these torturous bonds that I, Epicharis, now find a resting place in death.)

(269, 11. 725-36, emphasis added)

The "itzt" (jetzt, now) of Epicharis's suicidal taunt reveals, first of all, the layeredness of the play's historical and gendered nature as performance. ${ }^{34}$ Logically, the "itzt" demands to be read as a reference to the "real time" of history and thus facticity of her death in the play. And yet, its proximity to the invocation of a future stage ("Schauplatz") on which she and Nero will be portrayed as martyr and fiend respectively also fills the "now" of her speech with an awareness not of its reality but of its artifice. For in the Jetztzeit of the production, these words were, of course, uttered by a boy playing a woman who was engaged not in the reality but in the miming of death. That Epicharis is already "on stage" even as she utters the "itzt" thus marks her status not as the "original" she claims she will be, but as a reproduction, a quotation in drag, 
from both Tacitus and Desmarets. Here, in the culmination of the explicit scenes of torture, Epicharis is revealed to be in numerous places, past and present, history and fiction, in Rome in the play and on stage in the "real world" of the school. The temporal and spatial coincidence of her various sexual identities emerges in equally complex ways.

Lohenstein's version of Epicharis's identity relies on both covert and overt references that mark the character as a quotation. In act 1 and now, in the "itzt" of act 5, these quotations represent in condensed form textual inversions that trouble the notion that she could signify a single identity at all. At the beginning of her final speech here, for example, Epicharis recalls another woman, an "Athenian," who disdained torture just as she does. Lohenstein expands this reference in his notes; the woman whose constancy Epicharis would mime is the famous whore, Leaena, who, refusing to betray the conspiracy of Harmodius and Aristogiton in Athens in 514 B.C.E., is alleged to have bitten off her tongue as she was being tortured in order to prevent herself from implicating them in the plot $(292,11.221-26)$. The citation of the case of Leaena would seem to work to confirm Epicharis's identity as an exceptional-and exceptionally brave-woman. Yet, in declaiming lines that associate him/her with this particular female martyr, the boy playing Lohenstein's Epicharis subtly reveals both the hybridity of her femininity and the splitness of his masculinity as well. Her (and his) doubled sex becomes visible as we "descend" into the notes.

In his elaborate glosses to the many classical allusions in this play, Lohenstein gives as his source for the Leaena parallel "Tiraquell. ad L. Connub." Decoded, the reference is to Andreae Tiraquellus's De Legibus Connubialibus, et Jure Maritali (On the laws of wedlock and marital law), originally published by the French humanist in Lyon in $1515 .{ }^{35}$ The text is a fascinating one, full of early modern microbiological lore about sex difference as well as information on the legal rights of married and unmarried women. Of particular interest in connection with his section on Leaena is the lengthy, rather hysterical section on the heat content of males and females that follows it directly. "Mares sint foeminis calidores" (males are warm females), Tiraquellus states categorically. Elsewhere, he writes: "mulieres" are "viri frigidores" (women are cool men). ${ }^{36}$ These claims are conventional in the tradition; they are derived from Aristotle and Galen, whom Tiraquellus cites, and demonstrate with what terrifying ease apparently stable biological boundaries can be transgressed. Heat up a woman, and she may become male. ${ }^{37}$ Like his contemporaries, Tiraquellus seems to have taken such biological instability for granted. His tome nevertheless appears to want to patrol the borders of cultural gender identity when too many transgressions occur. It has trouble doing so, as the example of Leaena shows. 
Tiraquellus's information on "Leaena meretrix," Leaena the whore, is located just prior to his microbiological excursus, in the section entitled: "Mulierum in tormentis constantia" (The constancy of women when being tortured) ${ }^{38} \mathrm{He}$ cites numerous sources for the story, including Pliny's Natural History, a series of first- and second-century authors of military and geographical handbooks (Pausanias, Polynaeus, and Athenaeus), the church fathers Tertullian and Ambrose, the third-century author Eusebius, and the sixth-century grammarian Lactantius. Of particular interest is the reference to his earliest source for the story, namely books 7 and 34 of Pliny; the relationship of the legend as told there to the subsequent versions that Tiraquellus cites is noteworthy for the impact it has on Tiraquellus's own gloss. Pliny's description of Leaena in book 7, chapter 23, reads as follows:

Patienta corporis, ut est crebra sors calamitatum, innumera documenta peperit, clarissimum in feminis Leaenae meretricis, quae torta non indicavit Harmodium et Aristogitonem tyrannicidas.

(Bodily endurance, so fertile of disasters is fate, has produced countless examples, the most famous in the case of women being that of the harlot Leaena who on the rack refused to betray the tyrannicides Harmodius and Aristogiton.) ${ }^{39}$

There is no mention here of the famous tongue spitting episode quoted by Lohenstein's Epicharis. Later, however, in book 34, chapter 19, section 72, of the Natural History, which Tiraquellus also cites, Pliny explains that the Athenians erected a statue of a lion in honor of Leaena, the strength symbolized in her name taking on bestial form. This is probably the source of Lohenstein's Epicharis's reference to the "Ehrenbild" at line 727. The artist was "instructed," according to Pliny, "to represent the animal as having no tongue" (in opere linguam addi ab artifice vetuerunt) to indicate the reason why she was to be remembered-namely, for refusing to betray the two men. There is no indication that she lost her tongue in a gesture of self-mutilation; rather, the absent tongue is clearly to be read as a symbol. ${ }^{40}$

An examination of the way in which Lohenstein's source, Tiraquellus, used his source, namely Pliny, reveals certain textual manipulations, dislocations, and even embellishments. In the first mention of Leaena in chapter 7, for example, Pliny mentions neither the statue nor the significance of its features. Rather, he continues with his discussion of bodily endurance by noting the following story:

[Patientia corporis ... clarissimum] in viris Anaxarchi, qui simili de causa cum torqueretur praerosam dentibus linguam unamque spem indici in tyranni os expuit. 
(Among men [the most famous example is] that of Anaxarchus, who when being tortured for a similar reason bit off his tongue and spat the only hope of betrayal in the tyrant's face. $)^{41}$

Here the man, Anaxarchus, not the woman, Leaena, is the "original" practitioner of self-dismemberment in the face of unbearable torture. Lohenstein would have been aware of the male origins of the act in Pliny's version had he consulted Tiraquellus. His notes, of course, indicate that he did.

Now Tiraquellus makes it clear that his later sources for constant women and men differ significantly from Pliny. The second-century Atticist Pausanias, for example, refers to Leaena, her death, and the statue in book 1, chapter 23 of his Graeciae Descriptio (Description of Greece), but neither her silent endurance of torture nor the tongueless nature of the lion statue is described..$^{42}$ More significant, both for Tiraquellus, who cites their texts in full, and for Lohenstein, Tertullian (160-240 C.E.) and Ambrose (c. 339-97 C.E.) conflate the two examples from Pliny, grafting a male deed onto the woman's name. Thus, in Tertullian's Apologeticus (Apology), it is Leaena, "Attica meretrix" (Attic whore), identified as "Pythagorea quaedam" (a certain Pythagorean) in Ambrose's De Virginibus (Concerning Virgins) rather than Anaxarchus, who dismembers herself just before death. ${ }^{43}$ Tiraquellus notes that his other sources, Eusebius and Lactantius, both confirm the sex change. ${ }^{44}$

Comparing the numerous source references in Tiraquellus's text reveals what has happened in the process of philological transmission. The "original" tongue spitting story had been identified by Pliny with Anaxarchus, who in his silent bravery resembled no one so much as Leaena; Tertullian, Ambrose, and the others seem to have collapsed the two separate but related legends into one, allowing them to contaminate one another. The tradition of the self-mutilating woman was born. It is this conflation, indeed confusion, of textual traditions and sexual identities that Tiraquellus himself chooses to repeat by identifying Leaena with the courageous act. Lohenstein follows Tiraquellus in his foregrounding of the gesture on the part of a woman in turn.

In the expanded context of the crossovers represented by his sources, Tiraquellus's text thus reveals the difficulty of pinning down not just masculine and feminine characteristics, but male and female bodies as well. His reaction to the manifest inversion of the standard gender binarism of loquacious women and brave, silent men that Epicharis represents is nevertheless strong and direct. Hard upon the discussion of Leaena follows a lengthy account of the story of Epicharis as a second example of female constancy. Lohenstein may have originally found a 
reference to Tacitus here (see my later discussion). But immediately after recounting her story, Tiraquellus proceeds to deny categorically that it is possible for women to be as constant as these two narratives would suggest. "[N]emo enim unquam mihi persuadebat" (No one has persuaded me), he asserts, that women can be this strong, since in fact "natura" (nature) has made them "praecipites, imbecilles, infirmas, debiles, varias" and "mutabiles" (hasty, stupid, weak, feeble, changeable, and inconstant). This "nature," Tiraquellus concludes, "ut late comprobatum est" (has been widely confirmed). ${ }^{45}$ The "proof" that women cannot be as constant as the stories of Leaena and Epicharis suggest lies in an early modern microbiological tradition that mandates their lability, the tradition that Tiraquellus proceeds to explore at length in his text.

There is no question that Tiraquellus was a misogynist. It is not clear, however, that he was a bad scholar-that he failed, that is, to check the Leaena story in Pliny, his earliest source. Rather, in terms of the habits of a Renaissance humanist, he was using fairly traditional methods, as the context of his commentary on Pliny confirms. For, in the margins of his text where the Leaena legend as it is found in the Natural History is reported, Tiraquellus has noted: "Plinius lapsus" (Here Pliny was wrong). In the text proper, he explains that what he means is that Pliny was wrong to have suggested, in chapter 34, that the absence of the tongue on the Leaena statue at Athens was only symbolic. It was, rather, strictly speaking, representational, for Leaena had herself bitten off her tongue when subjected to torture; "ipsa sibi linguam amputavit" (she bit off her own tongue), as Tertullian and others tell us, Tiraquellus explains. The gloss is a product of humanist "castigation"; Tiraquellus knew his Pliny but disputed it. Relying on later texts for information on how to "correct" and "improve" an earlier one, he produced a pure and "genuine" reading meant to represent a more "original" source by grafting the Anaxarchus gesture onto the female body of Epicharis. The move is suggestive of the ease with which a female costume was donned by the Breslau schoolboy playing her role. More important, however, the fact that Tiraquellus's Epicharis could adopt and absorb a traditionally male act of self-mutilation associated with Anaxarchus into her repertoire of female gestures shows how easily a woman could act like a man - and a man could act like a woman in turn.

Tiraquellus's "correction" led him to a contradiction that he was unable to accept, namely, to the "reality" of a tradition of constant women whose existence he has subsequently to deny. The sex-change operation performed on the classical Pliny text by the church fathers presented the French humanist with a profound quandary, because what Tertullian and Ambrose were suggesting was that women were indeed as capable 
as men of displaying courage under duress. In agreeing with them over Pliny, Tiraquellus was positing a gender equity in which he manifestly did not - or at least claimed not--to believe. In the context of this particular citational community, however, such equity was by no means unusual, given the ideology of "equal opportunity" for women embedded in the tradition of Christian martyrology. ${ }^{46}$ For Tiraquellus, the unsettling corollary of this interruption of conventional gender codes would had to have been that even as women could be silent and strong, men could prove themselves to be garrulous, stupid, and weak. Ironically, the possibility of permeable borders between the sexes produced by the blatant case of philological incorrectness introduced by Tiraquellus's preference for Tertullian's and Ambrose's versions of the Leaena story over Pliny's made all the more necessary the production of the rest of Tiraquellus's massive tome, which was in fact designed to firm up those borders. At the same time, his act of humanist castigation also opened up the possibility for Lohenstein to insert additional productive uncertainties into his play.

Both the character of Lohenstein's Epicharis and the play that bears her name profit by our and the playwright's knowledge of the split gender of the Leaena reference, a knowledge mediated to us by Lohenstein's note to Tiraquellus's text. The female hero was played by a boy whose gestures were as male as those of Tiraquellus's Leaena, whose tonguespitting identity originally belonged to Anaxarchus, according to Pliny. Lohenstein knew his Pliny, or at least so other notes suggest. But he chooses to give Tiraquellus as his source. In so doing, he in effect required the cross-dressed schoolboy to model his stage gestures on the example of an explicitly female martyr. Yet, the young actor might not have felt the contradictions indicated by his role so strongly had he been aware of the difference between the Pliny "original" and the Tiraquellian "correction," aware, that is, that behind the sex confusion of Tiraquellus's Leaena there were really Pliny's distinct cases of female and male constancy. It is not too much to assume such an awareness, because Pliny had entered the German Protestant school curriculum with Melanchthon, if not before ${ }^{47}$ But the notes to Epicharis with the Tiraquellus reference were available in print the year before the play was staged, and, in those notes, it is not Pliny but clearly Tiraquellus and his female martyrs to whom Lohenstein refers. The philological choice represented by Lohenstein's reference to Tiraquellus's Leaena only makes sense if Lohenstein meant to challenge the boy playing the role to confront the complexities of a sex-gender system that would forbid him from playing the brave, female part. The transvestism of the actor thus calls attention to the mixed gender logic of the source, with Anaxarchus lurking somewhere deep in the margins of Lohenstein's play. The implications of 
these sexual and textual transgressions would have become apparent no later (if, indeed, not earlier) than precisely the very sequence of scenes in which the reference is made, namely the scenes in which Epicharis's body is subjected to violent abuse.

The scenes in which Epicharis is tortured on stage call attention to her split gender not only intertextually by means of the Tiraquellus reference, but also because of the material demands involved in producing the play. In Desmarets's novel as well as in a 1644 French play about Seneca's death thought to have been a collateral source, the torture is either merely reported, said to be rumored, or anticipated by the stage action, as when we witness Epicharis dragged off to her doom: "Entrainez la, soldats," commands the Nero of Tristan l'Hermite's play, La Morte de Sénèque, "viste, qu'on la déchire" (Take her away, soldiers, and quickly, see that she is torn apart!). ${ }^{48}$ Lohenstein chooses, however, to depict on stage the use of boiling oil, sulphur, pitch, the rack, and glowing tongs to mutilate the female body. He follows Tacitus in his sequencing of the torment. Tacitus writes:

Atque interim Nero recordatus ... Epicharis attineri ratusque muliebre corpus impar dolori tormentis dilacerari iubet. At illam non verbera, non ignes, non ira eo acrius torquentium, ne a femina spernerentur, pervicere, quin obiecta denegaret. Sic primus quaestionis dies contemptus. Postero cum ad eosdem cruciatus retraheretur gestamine sellae (nam dissolutis membris insistere nequibat), vinclo fasciae, quam pectori detraxerat, in modum laquei ad arcum sellae restrictio indidit cervicem et corporis pondere conisa tenuem iam spiritum expressit.

(In the meantime, Nero recollected that Epicharis was in custody ... and, assuming that female flesh and blood must be unequal to the pain, he ordered her to be racked. But neither the lash nor fire, nor yet the anger of the torturers, who redoubled their efforts rather than be braved by a woman, broke down her denial of the allegations. Thus the first day of torment had been defied. On the next, as she was being dragged back in a chair to a repetition of the agony - her dislocated limbs were unable to support her--she fastened the breast band (which she had stripped from her bosom) in a sort of noose to the canopy of the chair, thrust her neck into it, and, throwing the weight of her body into the effort, squeezed out such feeble breath as remained to her. $)^{49}$

Lohenstein takes care to follow his source in spreading Epicharis's torture over two sessions, locating the first in act 3, the second in act 5, thus exposing the abused female body to view for an extended period 


\section{Epicharis}

of time. The detail is excruciating; Lohenstein's annotations indicate that he knew Carpzov's Practica rerum criminalium (Practices in criminal matters) (1635), a handbook that belonged to what Edward Peters has called the "great swell" of "literature on criminal procedure and torture . . . minutely regulating" the actions of authorities; such tomes grew out of the "encounter" of the period's "legal needs and thought with the body of Roman law." ${ }^{50}$ Lohenstein's Epicharis is subjected on stage and at length to the horrors described in Carpzov's tome. Moreover, while the playwright was familiar enough precisely as city Syndi$k u s$ with the intricacies of the legislation of torture to know that both freed persons and women were normally exempted from the quaestio, he also knew that the one exception to this "lenience" was in the case of special crimes such as the crimen majestatis, or treason, of which Epicharis is, of course, accused. ${ }^{51}$ Her will to protect her fellow conspirators nevertheless remains firm. After her citation of the alleged Leaena parallel, the act of desperate suicide described by Tacitus and depicted in the frontispiece to the play concludes the staging of these shocking events.

The attention to gender doubledness in this scene underscores the fundamental ambiguity of the sex-gender system of the play already apparent in the intertextual space of the notes. First and foremost, Epicharis is said by the other characters to distinguish herself as a woman both from assumptions about female weakness and from the male conspirators, who, to a man, betray their fellows when merely threatened with torture. They stress her exceptional nature against the background of early modern sexual stereotypes; "Wird künfftig uns die Welt wol Glauben meßen bey?/Daß sie Epicharis ein Weib gewesen sey;/Die klüger als ein Mann/behertzter ist als Helden?" (Will the future accord us any measure of belief that Epicharis, smarter than any man and braver than [most] heroes, was a woman?) (196, 11. 421-23). In crafting these lines, Lohenstein has merely followed Tacitus, who wrote: “Clariore exemplo libertina mulier in tanta necessitate alienos ac prope ignotos protegendo, cum ingenui et viri et equites Romani senatoresque intacti tormentis carissima suorum quisque pignorum proderent" (An emancipated slave and a woman, by shielding, under this dire coercion, men unconnected with her and all but unknown, she had set an example which shone the brighter at the time when persons freeborn and male, Roman knights and senators, untouched by the torture, were betraying each of his nearest and dearest). ${ }^{52}$ Yet, Epicharis's exceptional status as a woman is only indirectly present here in the source; Lohenstein's lines state it outright.

Nevertheless, as the conditions of production remind us, Epicharis's "true nature," namely that she was being played by a boy, would have 
emerged in precisely these scenes of exemplary femaleness, since the focus on the body of the torture victim would have brought the question of his/her anatomy to the fore. It is possible to imagine a staging of these scenes whereby strategic placement or use of props could have masked the actor's sex. There are documented examples of papiermâché breasts and life-sized dolls, for example, being used in torture scenes in fifteenth- and sixteenth-century martyr plays. ${ }^{53}$ Lohenstein's text nevertheless seems almost deliberately to work to underscore the disjunction between play and player by heightening the ambiguity of what can and cannot, will or will not be seen; "Ziht an/und tröpft ihr Pech und Schwefel auf die Brust" (Fall to, pour pitch and sulphur on her breast) $(218,1.553)$, "[s]o reißt ihr Kleid entzwey" (tear her dress apart) $(219,1.585)$. Epicharis's miraculous ability to debate Nero, inspire her fellow conspirators, and even write letters in spite of her broken body clearly recalls familiar topoi from the tradition of female martyrdom depicted in hagiographical texts in which the viewers' gaze is fixed, in unwavering fashion, on the naked woman's tormented body. ${ }^{54}$ As the object of such a gaze, however, the actor's boy body would have been clearly seen beneath the woman's garb.

Pierre Béhar has argued for the explicit association of Epicharis with martyr drama, suggesting that Lohenstein based his decision to stage Epicharis's torture on a print published in connection with a planned production of Andreas Gryphius's Catharina von Georgien, in which the queen's naked body faces the viewer head on. ${ }^{55}$ The frontispiece of the 1665 edition of Lohenstein's Epicharis confirms Béhar's interpretation that Lohenstein intended for his play to participate in this tradition, and sustains the fiction of the rebel's femaleness by endowing her with recognizable breasts. Precisely in this moment, it would have required a willing suspension of generic memory, not to speak of disbelief, for both the players and the audience to not have been confronted with the gap between male and female bodies created in and by the torture scenes, a gap underscored by both the boy's voice recounting Epicharis's adventurous cross-dressing in act 1 , declaiming the Leaena reference in act 5 , and otherwise performing miraculous feats center stage here. The visibility of the boy's body as he attempted to pass as a woman in these scenes may well have been intended to shorten or hide the distance between the body of the woman he was playing and conventional gender ideology, which would have had her be not nearly so brave. Yet, this distance is maintained, even increased when the notes draw attention to the malleability, indeed the artifice, of ideological and anatomical distinctions between male and female behavior at their textual origins.

The task that the Breslau schoolboys faced, then, was one of distin- 
guishing between (illusionistic) sex and (ideological) gender. Where the stage Epicharis is most manifestly a boy, stripped and tortured almost to death, she invokes Tiraquellus's female martyr, Leaena; conversely, when she most clearly exemplifies "virile" virtues by remaining true to her political cause even under extreme physical duress, she reveals her textual origins in a Tiraquellian gloss that substitutes the Athenian woman for the "original" man, Anaxarchus, of Pliny's text. The fluidity of the borders between both men and women and between what culture claimed were masculine and feminine characteristics seems as pronounced here as the instability of biological sex differentiation must have been for Tiraquellus. Yet the clearly unsettling nature of this fluidity in gender assignments for the French humanist became the occasion for Lohenstein to set the "signifying act" of the boy actor's body into play with the story of Epicharis, the female "signified" of the play, in a public way. ${ }^{56}$

\section{The Text That Is Not One: Lohenstein's Tacitus}

The philological trail suggested by the notes to the Leaena reference in Lohenstein's Epicharis might at first glance seem to work to dismiss potential threats to early modern gender ideology as conventionally understood by revealing that Epicharis's female steadfastness is in fact not "out of place." If one digs deeply enough into the textual origins of her exceptional nature, that is, one finds embedded in the sources the explanation of her apparent strangeness, the "fact" that her behavior was originally that of Anaxarchus, a man. Lohenstein's sources reveal the philological reality, that is, of the phenomenon that was so anathema to Tiraquellus, namely the accessibility to some women of behavior coded as masculine, an accessibility that would belie any strict separation or valorization of individuals according to sex. Indeed, by citing Tiraquellus rather than Pliny, Lohenstein tips his hand and shows that he would have the textual origin of his martyr be female even as he scripts stage action for boys. If, however, Lohenstein's reference in his notes to Tiraquellus seems too fleeting or arcane to assure that he would have been conscious of the complex origins of Epicharis's reference to Leaena, a brief investigation of his primary classical source, namely Tacitus's Annals, book 15, in editions that Lohenstein knew, confirms the fraught nature of his protagonist's sex and gender, of both the person of Epicharis, that is, and of the actions she is made to perform.

It is commonly acknowledged that Tacitus's account of the Pisonian conspiracy is the main classical source for the Epicharis story. In the en- 
cyclopedic "Register" of Lohenstein's sources that follows the Römische Trauerspiele, Klaus Günther Just suggested some forty years ago that, in composing his play, the playwright used either an edition of Tacitus edited and annotated by the famous classicist and political theorist, Justus Lipsius, or the commentary on Tacitus published by Christophorus Forstner. ${ }^{57}$ Additional clues as to the logic of the crossover phenomenon that the German Epicharis represents may be found in these editions in the scenes of torture that I have focused on thus far. In the section of $\mathrm{An-}$ nals, book 15, devoted to Epicharis's suffering and death, for example, Tacitus describes her astounding constancy; she is impervious to the "lash and the fire" (illam non verbera, non ignes ... pervicere) and refuses to compromise her fellow conspirators. Either to prevent herself from confessing under further duress or to escape the second day of torture and pain, Epicharis conceives of the ingenious method of taking her own life depicted in the frontispiece illustration of the play. Of Lohenstein's likely sources, only Tacitus describes the suicide in detail; it is thus clear that Lohenstein relied on him here. Epicharis creates a kind of a noose ("laqueus") out of a piece of her clothing, attaches it to the chair ("gestamine sellae") in which she is sitting, and, thrusting her neck into the noose, strains against it such that she succeeds in hanging herself from a seated position. Lohenstein's Nero alludes to this improbable procedure and thus to his author's use of Tacitus as source when he commands: "Verwehrt es/sie wil sich erwürgen" (Prevent her from strangling herself!). It is too late, the executioner cries: "Sie ist fort" (She is dead) $(269,1.737)$.

Of particular interest to a discussion of the shifting sexual identities in which Lohenstein's Epicharis is inscribed both textually and on stage are Forstner's glosses on this scene. In his In tres postremos libros Annalium C. Cornelii Taciti Notae Politicae (Political notes on the last three books of the annals of Cornelius Tacitus) (Frankfurt, 1661), Forstner's note on the line, "illam non verbera, non ignes ... pervicere," reads as follows:

$[\mathrm{P}]$ ar huic historia extat apud Tertullianum in Apologetico (a) \& alia libro ad Martyres [!]: (b) alia item apud Ammianum Marcellinum: (c) alia de Leaena meretrice apud Athenaeum XIII. Deipnosophiston, \& Plutarchum libro de Garrulitate: apud eundem alia de Aretaphilia Cyrenaea libro de virtutibus mulierum; praeter illas, quae apud Valerium Maximum vulgatae sunt: (d).

(A similar story can be found in Tertullian in his Apologeticus (a) and another in the book to the martyrs: (b) similarly, another in Ammianus Marcellinus: (c) and another about Leaena the whore in Book 13 of Athenaeus, Deipnosphistos, and in Plutarch's book 
"On Garrulity": and in the same author another about Aretaphilia of Cyrenaea in his book on "The Virtues of Women"; in addition to those [stories] that Valerius Maximus published: (d).)

At the bottom of the page, the exact citations to the various sources are given: "(a) C. 50," “(b) C. 4," "(c) 14 hist.," and "(d) lib. 3. C. 3." $58 \mathrm{Had}$ Lohenstein, in his research of the story of Epicharis, pursued any of the sources Forstner cites, what would he have found?

The first two references to Tertullian in fact contain versions of the Leaena story with which Lohenstein would have been familiar via Tiraquellus, namely of a miraculously constant woman in ancient times. Forstner's Tacitus could thus have provided Lohenstein with additional material concerning the explicitly female martyr, Leaena, even though, again, it is Tiraquellus whom Lohenstein cites when he glosses his Epicharis's reference to her. The two other sources to which Forstner gives detailed references, the notes annotated as " $c$ " and " $d$," respectively, contain "new" information, however. "14. hist." refers to book 14 of the fourth-century Res Gestae (Histories) by Ammianus Marcellinus; "lib.3.c.3." refers to book 3, chapter 3 of the first-century De dictis et factis memorabilibus (Memorable deeds and sayings) by Valerius Maximus. ${ }^{59}$ And yet, this "new" information derived from Ammianus Marcellinus and Valerius Maximus only confirms the ambiguity introduced into Lohenstein's play by Tiraquellus's Leaena references, because it too reveals the playwright's choice to focus on the female in his play written for boys. Lipsius's notes in his C. Cornelii Taciti Opera Quae Exstant (Extant works of Tacitus) (Antwerp, 1668; originally published as a commentary in 1574) on the suicide chair, "gestamine sellae," also refer to Ammianus Marcellinus, finally, but to book 29 rather than to Forstner's book 14 .

Forstner's and Lipsius's references to authors like Valerius Maximus and Ammianus Marcellinus are significant for several reasons. First, they demonstrate again that Roman history was in no way monolithic for late humanists like Lohenstein. It was available, rather, in multiple versions, many of them even more unsystematic and anecdotal than Gronovius's Livy, which I examined in detail in chapter 1 . The fragmentary appearance of Lohenstein's references was thus not of his own devising; he was merely mimicking the "originals" with great accuracy when he cited a parallel ancient event here, an obscure classical reference there. That the versions of history he presents might sometimes conflict with the sources only represents the degree to which the sources were not unanimous in themselves.

Second, and more important in the immediate context, the Valerius and Ammianus references trouble the relationship between male and 
female identity in Lohenstein's play in ways that complement the hybridity we have already witnessed in his use of Tiraquellus. For when we look, for example, to Ammianus and Valerius in any of the numerous contemporary editions in which they were available, we find that the cases of constancy and suicidal bravery under duress in which both Lipsius and Forstner would have found parallels to Epicharis in fact all involve men rather than women. Like Tiraquellus, Lohenstein's Tacitus was thus replete with sex-gender crossovers. Lipsius saw similarities in the story of the African leader, Firmus, for example, who, in book 29 of Ammianus's Histories, hangs himself on a rope suspended from a nail rather than succumb to the Romans, in 376 c.E. ${ }^{60}$ The reference to book 14 of Ammianus's text (the book that Forstner preferred and which he includes in his gloss) seems more logical, however, since it contains the story of the young rebel, Eusebius, who was involved in a plot against the corrupt Constantius Gallus Caesar in mid-fourth-century Antioch. Like Epicharis, Eusebius was tormented in a cruel fashion, and subsequently led off, defiant, to be executed. Ammianus's description of his torture (which Forstner references in his Tacitus commentary-302) sounds curiously like a conflation of Epicharis's, Leaena's, and Anaxarchus's stories.

Qui [Eusebius] ita eviscaeratus ut cruciatibus membra deessent ... fundato pectore mansit immobilis, nec se incusare nec quemquam alium passus. ... Et ducebatur intrepidus, temporum iniquitati insultans, imitatus Zenonem illum veterum Stoicum, qui ut mentiretur quaedam laceratus diutius, avulsam sedibus linguam suam cum cruento sputamine in oculos interrogantis Cyprii regis impegit.

([After Eusebius] had been so disembowelled that he had no parts left to torture ... he remained unshaken, with stout heart, neither deigning to accuse himself nor anyone else. . . He was led off to execution unafraid, railing at the wickedness of the times and imitating the ancient Stoic Zeno, who, after being tortured for a long time, to induce him to give false witness, tore his tongue from its roots and hurled it with its blood and spittle into the eyes of the king of Cyprus, who was putting him to the question.) ${ }^{61}$

Forstner's knowledge of Valerius Maximus's earlier compilation of exemplary ancient deeds would have confirmed Ammianus's association of a tongue-spitting Zeno with a male figure like Eusebius who is constant under torture. In the text Forstner cites-book 3, entitled "De patientia" (On endurance, or Constancy), chapter 3-Valerius in fact recounts the Zeno story, although here the ear (rather than the tongue) 
that Zeno tears off with his teeth is not his own ear, but rather that of the tyrant Nearchus, who has ordered the torture. Although Forstner does not refer to it, it is actually a chapter of the book of Valerius's text directly following the Zeno reference, namely book 4 , that is more similar to the Epicharis story. But here too the sex of the brave martyr is male; the tongue-spitting story is associated with none other than Anaxarchus, with whom we are familiar from Pliny. Valerius's Anaxarchus, also not surprisingly, accuses the tyrant who torments him, Niocreon of Cyprus, of effeminacy just before he effectively silences himself, thus demonstrating that self-dismemberment belonged to the register of masculine gestures, the very opposite of what we post-Freudians might expect it to be. ${ }^{62}$

Thus, when Lipsius and Forstner read and considered the story of Epicharis in Tacitus, the parallels they saw and handed on to readers like Lohenstein were not those of other constant women (although Forstner also lists these parallels in a separate gloss) ${ }^{63}$ but of explicitly male martyrs. Both Ammianus and Valerius have their victims cite Zeno, moreover, extending and prolonging the tradition of male identified tongue spitters in turn. It is no wonder, then, that Lohenstein's Epicharis seems so virile; in texts to which Lohenstein had access and in the performance during which she was played by a boy, she was in fact deeply indebted to male predecessors. Even as he chooses, then, to focus on a woman as the title figure of his play and to have her invoke Leaena as a model, Lohenstein indicates in his notes that this lineage of women derives from an intertextually masculine space. In this respect, his play-both the text and the production-replicates the gender loyalties of the source by allowing a boy dressed as a woman with a history of cross-dressing to recall the actions of a woman that were "originally" male. Even though there is a curious focus on the female body of the political martyr, then, it is the boy whose gender identity is at stake here. At the same time, however, Lohenstein does allow the (tortured) female body of Epicharis to intervene in this hom(m)otextual sphere by citing Tiraquellus, who, in turn, cited others on the rejection of female garrulity, and by producing the torture on stage. The multiple textual and sexual transgressions in Epicharis may seem as mystifying as Pliny's peripatetic trees, but they go a long way in demonstrating that the interpellation of the incipient male subject into the ideological behaviors of social and political patriarchy was no simple affair. The historical and political location of the schools in Breslau in particular sheds additional light on the apparent anomaly of a text that would appear to have chosen to favor the representation of strong women by the boys. It is to the specifics of this location that I now turn. 


\section{Agrippina (1665) and the Politics of Philology: Sons and Mothers in Early Modern Central Europe}

\section{Sons and Mothers in Early Modern Central Europe}

Act 3 of Lohenstein's 1665 play about Nero's assassination of his mother and erstwhile coregent, Agrippina, in 59 c.E., contains what could arguably be deemed one of the most salacious scenes produced on the early modern stage in central Europe. The astoundingly explicit rendering of the episode of incestuous seduction is based on suggestions by Suetonius and Tacitus of improper sexual relations between mother and son. ${ }^{1}$ The material realities of the production of Agrippina might well have made the erotically charged scene all the more outrageous; they might also help explain why the schoolboy actors initially had difficulty securing permission from Breslau's city council for another production after it was performed in 1666. Although Schlesinger designates these years, and especially 1669, when Agrippina appears to have been revived, as the "Glänzzeit" (heyday) of Protestant school theater in Breslau, there are many indications that throughout these years, the authorities were concerned enough with potential excesses associated with the plays to have tried to maintain strict oversight over their production. And indeed, no more plays were staged after $1671 .^{2}$ The incest scene in particular calls attention to the potentially offensive dramaturgical realities associated with this text in particular, which called for a boy playing a female role to both seduce and be the object of seductive behavior on the part of another schoolboy playing a man.

I focused in chapters 1 and 2 on the troubling yet ultimately revealing fluidity of the boundaries between the sexes as well as between the staging of history and the history of the (transvestite) school stage in Lohenstein's plays. In view of the explicit enactment of mother-son incest for which the text of his play about Agrippina in particular calls, an additional level of textual transgression demands attention, one that addresses the issue of how the apparently marginal phenomena of these German-language school plays from eastern central Europe can be seen as zones of contact productive of new knowledges central to our understanding of gender, textuality, and politics in the early modern period. 
This particular transgressiveness occurs not where one might expect it when considering this scene, namely in the sexual dynamics that surely characterized its literal staging. Rather, the boundaries of propriety overstepped here are those associated with the dedicatee of this play, Duchess Louise of Liegnitz, Brieg, and Wohlau, who, modern sensibility might suggest, may well have found the erotic contortions called for by the play unbearably shocking. The anomalousness of Lohenstein's oeuvre - and its place in the dedicatory economies of the day-would seem to stand out clearly here. Yet, other codes of acceptable (if not dominant) behavior, particularly for a specific class of women, namely those in positions of power, become visible once we consider these startling scenes from the new point of view that a "slow" philological reading permits. These codes call attention to themselves at various moments in the learned apparatus of Agrippina and challenge the image of normative gender that has been produced by scholars of the period to date. The notes ask us to reconsider the gender politics of the early modern world from the point of view of the small principalities that made up the Silesian territories of the Holy Roman Empire in the second half of the seventeenth century. Once Lohenstein's play is reembedded in this world, the logic behind the playwright's dedication of his strange text to Louise begins to make more sense.

At first glance, it appears easy to answer the question of what we are to make of the fact that, when Agrippina was published in 1665, one year before it was produced, the play was dedicated to the duchess. Like the historical Agrippina, Louise was the daughter, wife, and mother of sovereigns; several years after the play's initial production, she became regent of one of the principalities located close to Breslau after her husband had died and before her son came of age. The conceit of the reproduction of ancient Rome's political institutions and history in the here and now of the Holy Roman Empire of the German Nation was a common one; stage action in plays about classical Rome could mirror developments that were to occur in an early modern imperial frame, albeit here on the local territorial level. Yet in the case of Louise, this reproductive conceit is rendered nearly impossibly problematic, for if the world in the play were indeed to have been thought capable of spilling over into the world in which it was produced, what would the duchess have made of the play's depiction of the violence and depravity of Agrippina's relationship with Nero? Was Lohenstein suggesting that she would become seductive and Agrippina-like to the young prince of Liegnitz and future hope of Silesia, George William (just five years old when the play was produced), or was he cautioning her-in somewhat presumptuous fashion - not to become so? Or was the play to act as a kind of warning 
that her son might become murderous, and thus Nero-like, to her, his protector, in turn? The "kluge Fürstin" (wise princess) and "Preißwürdigste Regentin" (most praiseworthy regent), Louise, is described by her husband in the will in which he designated her as regent as a woman "mit Sanftmuth" (of a gentle nature) with an "ausgezeichneten Verstand" (excellent mind), a woman who understood Latin, French, and Italian, and possessed "alle fürstlichen Tugenden" (all princely virtues). ${ }^{3}$ Given the many parallels with the stage regent of the play, how, then, was the duchess dedicatee of the play to evaluate Agrippina's shocking sexual profile (an integral part of her political identity, according to the Roman historians) as it was presented in Lohenstein's text? Indeed, how were the young actors, future counselors and administrators in early modern political structures like the one that Louise oversaw, to conceive of a potential political context in which outrageous sexual behavior was consonant with a (female) ruler's "princely" role? These are just a few of the questions posed by the presence of the incest scene in Lohenstein's Agrippina, questions to which we begin to find answers by entering into the annotational universe of the text.

Ironically, the incest scene itself provides the best moment of access into a world in which there appears to have been a legitimate relationship between learnedness, women in power, and sex. The key to this relationship becomes visible first and foremost in repeated references in the dramatic dialogue itself to the case of the famous Persian queen, Semiramis, said in some source texts also to have committed incest with her son; these sources are among those cited in Lohenstein's notes to the play. Moreover, the textual apparatus of the Agrippina also contains references to the annotated editions of Tacitus that the playwright used in constructing the play as a whole; here, the conventionality of politically motivated sexual excess is also addressed. In earlier chapters, I have indicated how Lohenstein's learned glosses reveal a great deal about the intertextual means by which his apparently idiosyncratic renderings of familiar material can be made to make sense, how they can be read in such a way as to give us a sense of the political, institutional, and ideological landscape of early modern central Europe. The notes to Agrippina function in similar fashion by serving as a kind of textual monument to the ways in which late humanist learnedness was deployed to explain sexual licentiousness under a specific set of conditions in which female leadership was far more than a theoretical concern. "Excavating" the "margins" of the text allows us to discern a tradition of alternative political identities and sexual codes associated with these women; this tradition helps explain the logic of Lohenstein's dedication of his "lecherous" school play to Duchess Louise. ${ }^{4}$ The interpenetration of textual 
tradition and the material circumstances of the play's sponsorship in the case of Agrippina thus reveals the need for philology to understand an early modern gender system already so problematized by Epicharis, Agrippina's companion play, and rendered additionally complex here.

It is helpful, first, to investigate the material circumstances of Lohenstein's play about Nero's mother insofar as they reveal the contours of the clash between gender ideology and material realities in post-Thirty Years' War Silesia, particularly in terms of women's political profile in the upper and ruling classes. Produced by students at the Protestant Elisabeth-Gymnasium in Breslau in 1666, Agrippina was dedicated to Louise as duchess of the Silesian principalities of Liegnitz, Brieg, and Wohlau, by birth a princess of the influential house of Anhalt. In 1672, Louise became regent for her young son, George William, the last of the Piastian princes, the long-standing Silesian lineage well known for its irenic stance and exceptional status in the complex confessional politics of the eastern reaches of the post-Reformation and post-Tridentine Empire. $^{5}$ In spite of popular assertions that women were unfit for governmental positions, and even legally excluded from them by the Salic Law in France, the political realities of traditionally Protestant central European principalities such as Liegnitz created situations in which women could become regents in the absence of their husbands or during the minority of their sons. ${ }^{6}$ Only dynastic continuity and political alliances could protect their small fiefdoms from being swallowed up by an Empire ever on the lookout for both new sources of revenue and nonconformist areas to re-Catholicize and thus subdue.

In the case of Louise of Liegnitz, the struggle to retain control of the privileges granted to the Piastian territories after the Thirty Years' War in the face of both imperial pressure and internal factionalism ultimately led to a less-than-graceful acceleration of George William's majority in 1675 and thus to his mother's removal from the political scene. But during the period prior to this when Lohenstein was writing his play, Louise had been not just his biological parent but also the "LandesMutter" and a major figure on the Silesian political stage. Her achievements may have caused Lohenstein several years later to characterize her as an anomaly, "Wunder-Wercke des Weiblichen Geschlechtes" (a wonder of the female sex) and to be able to think only of male figures in the classical tradition as precedents for her political wisdom, ${ }^{7}$ but she was a female head of state nevertheless. Moreover, she was not unusual for the time. In the neighboring principality of Oels, for example, which was "ein weibliches Lehngut" (female fiefdom, or feudal estate), according to the Silesian chronicler, Friedrich Lucae, the line of succession officially ran through the females of the family. Thus Princess Elizabeth 
Maria could inherit the principality in her own right in 1647 and as a result step more easily into the regency in 1664 at the death of her husband, who had married into power when he married her. Elizabeth Maria ruled until her sons came of age in $1672 .{ }^{8}$ Lohenstein is known to have been employed as a Regierungsrat by Elizabeth Maria in Oels in 1668. Louise of Liegnitz too had relied on the poet-playwright for advice and rewarded him for his loyalty and services with the gift of an estate; her sponsorship - along with his high visibility in Breslau - may have been one of the reasons why Lohenstein was offered the position of Geheimsekretär in Liegnitz sometime before $1670 .{ }^{9}$ Although he turned down the offer and accepted the powerful position of Syndikus of the city in 1670 instead, Lohenstein appears to have remained close to the court of Liegnitz for the rest of his life. For as much as the Piastians stood to profit from associations with Breslau, so too did the city often find itself siding with the rulers of the surrounding principalities in its and their struggles for autonomy vis-à-vis a weakened and thus aggressive imperial hierarchy in need of increased revenues and assurances of loyalty in the volatile political context of the time. As Syndikus, Lohenstein relied heavily on his local connections in his negotiations with Vienna, particularly when he traveled to the imperial court in 1675 to negotiate a readjustment of the tax structure for Breslau and to oppose the stationing of imperial troops in the city. ${ }^{10}$ Thus, the reality of a female head of state was never far away.

It is in connection with the material realities of local political strategizing, realities that included the presence of powerful women, that Lohenstein can be seen to have come to rely in his research for many of his "political" school dramas, including Agrippina, on the annotational apparatus that accompanied a specific subset of the texts of classical historiography published during this period. In the learned marginalia of these texts, the uneasy parallels between ancient Rome and the Holy Roman Empire were examined in great detail. Lohenstein could have derived his stance on legitimate political behavior by female rulers both ancient and modern from this tradition of "political-historical philology" that Kühlmann has demonstrated was the early-seventeenth-century successor to the learned commentaries of the fifteenth and sixteenth centuries published in Italy, for example, texts that were themselves highly political, as Stephanie Jed has shown. ${ }^{11}$ I turn to some of these texts later. This northern version of seventeenth-century political philology found some of its most avid practitioners in the Rhineland, in Heidelberg, Straßburg, and as far west as Montpelier, where scholar-statesmen authored innumerable commentaries on classical historians that served Lohenstein as sources for his play. The profile of the political woman 
that emerges out of the margins of Agrippina relies on the gender ideology articulated in these editions, one strikingly at odds with any simplistic requirement of chastity, fidelity, and silence for women.

It was not only the playwright-statesman Lohenstein who would have been familiar with this strain of late humanist commentary, however. Women in line to occupy official political positions might also have had access to and interest in its lessons. Queen Christina of Sweden, who ruled between 1644 and 1654, is said to have read a chapter of Tacitus every day, for example, and called many of the German philologiststatesmen whom Lohenstein read to her court in the second half of her reign. ${ }^{12}$ In 1639, the learned Anna Maria van Schurmann wrote to Elizabeth of Bohemia, daughter of James I of England and then director of the convent at Herford, recommending the texts of Plutarch, Suetonius, and Tacitus, along with learned commentaries on them, as a means of acquiring a "connoissance des choses passées" (knowledge of historical events) and of learning "quel usage on peut tirer des examples antiques" (what use one could derive from ancient examples). ${ }^{13}$ Schurmann argues elsewhere in favor of education for women who would have the opportunity to put their learning to good use; she may well have been thinking of the "profession" of politics, which was in fact open to women of rank in specific cases at the time. ${ }^{14}$ The fact that they could read Latin and often were familiar with the great "Historicos" of the past is usually mentioned, finally, in the descriptions of such women in the pro-woman literature of the period. ${ }^{15}$ Often educated together with their brothers at the courts of many of the minor principalities in central Europe, the daughters of the smaller houses and dynasties would have studied classical history in editions in which the commentaries were just as significant as the original texts. ${ }^{16}$ Louise of Liegnitz was one of these. She may thus have recognized some of the issues articulated in Lohenstein's play as derived from these political glosses, particularly those of relevance for women in positions of power.

The underlying logic of several of these commentaries becomes particularly important for an understanding of Agrippina when it provides evidence of early modern standards of political behavior for powerful women that do not shy away from discussing (although they may not have condoned) adventures of the kind in which Nero and Agrippina, like Semiramis and her son, were said to have been involved. Their nearly postmodern logic is based on the argument that biological differences between men and women are relatively insignificant, particularly in the case of the ruling classes. The same rules for astute and effective political behavior are considered to be applicable to both men and women in this case, since in practice, political identity and access to 
power were determined primarily by confession and family connections rather than by sex. The Frenchman, Pierre Le Moyne, explains this position in his La galerie des femmes fortes (Gallery of strong women) (1647):

Disons encore, que s'il n'importe de quelle couleur [et] de quelle étoffe soit habillé le Pilote d'un vaisseau, pourveu qu'il entende la Carte, [et] qu'il ayt le science des vents [et] des Etoiles; Il n'importe gueres plus, de quel sexe [et] de quelle complexion soit le Corps, qui n'est que l'habillement de l'Ame qui gouverne. L'importance est que cette Ame soit instruite [et] bien conseillée.

(Let us say again, then, that the color and material of the garb in which the pilot of a vessel is clothed is immaterial, as long as he can read the map and understands the habits of the winds and the stars; it is hardly more important what the sex or makeup is of the body, since it is no more than the garb of the person [soul] in charge. The most important issue is that this person be well educated and well advised.) ${ }^{17}$

Lohenstein refers to Le Moyne's compilation of the stories of famous women in the notes to Epicharis, the play produced in conjunction with Agrippina in 1666. His interest in Le Moyne's work is not surprising. The two authors were similarly situated with respect to powerful women. Le Moyne's Galerie celebrated and was dedicated to Anne of Austria, widow of Louis XIII. Perhaps this was where Lohenstein got the idea of dedicating his Agrippina to the regent-to-be, Duchess Louise. Such contextual parallels allow us to discern how the German play converts the partisan claim made in the French text about the irrelevance of gender in the arena of political action into one of its underlying messages.

The famous and much cited case of the ancient Assyrian queen Semiramis plays a prominent role in Le Moyne's text $(174-75,191-96)$ and alerts us to her potential exemplarity in the historiographical commentary on which both he and Lohenstein relied precisely in terms of the twist in conventional gender coding that casts biological difference as in some cases irrelevant in the political realm. Deliberately obscuring her sex in the interest of political survival, Semiramis is said to have decided to clothe herself as a man at the outset of her political career, which, in some versions, began with her regency for her son. The cross-gendering effect of this legend may well not have been lost on Lohenstein as the author of multiple transvestite innovations in classical tales. Semiramis's reputation nevertheless derived precisely from the fact that, although clothed as a man, she was in reality a powerful woman, for, once established, she revealed her identity and was much celebrated in innumer- 
able treatises of the time for the excellence of her unexpected achievements. It is significant for our understanding of Lohenstein's Agrippina that Semiramis's reputation as a strategist and politician-both in Le Moyne's text and in humanist commentaries on her story as told by historians that Lohenstein could have read-offered an example of at least one powerful woman whose aberrant behavior was tolerated because she was endowed, as Maclean has written, with "heroic virtues" and power. ${ }^{18}$ The juxtaposition of Semiramis with Agrippina that occurs in Lohenstein's play begins to make sense when seen from this point of view.

The issue of extravagant sexual behavior in particular is also relevant in the Persian queen's case, since it was well known that, in addition to having a reputation for transvestite politics and political savvy, Semiramis had been accused of sexual indulgence, and is even said to have attempted to commit incest with the son for whom she initially ruled. The parallels to Agrippina's situation emerge with clarity here. The degree to which the early modern commentary tradition on the story of Semiramis highlights or obscures, explains or condemns her attempt at incest as evidence of a lascivious character, on the one hand, or as astute political maneuvering, on the other, provides an interesting insight into the early modern debate about the sexual profile of powerful women. Lohenstein would have been familiar with this debate, perhaps initially via Le Moyne, but then also in the commentaries on the classical historians that he mined for information on Roman history as he wrote. Duchess Louise may also have known about these discussions concerning the sexual activities of ruling women by means of her readings of the historians, if not also subsequently from her consideration of the notes of the play Lohenstein dedicated to her. Given the tense relationship between the Piastian principalities and Vienna during these years and the central role that women were being asked to play, there is thus no reason to think that the references to Semiramis as a powerful, if also sexually active, political woman in the play would have fallen on deaf ears.

An investigation of the intertextual relationship between Agrippina and Semiramis and of the standards of sexual conduct for female rulers in both the literal and figurative margins of Lohenstein's play thus calls attention to the complex realities of women's political power in this particular early modern central European context. Although the late humanist commentators on ancient history whose editions I examine here probably did not consider incest an exemplary or recommendable political strategy for either men or women, it nevertheless emerges out of the textual traditions concerned with the adventures of Semiramis and 
Agrippina with which Lohenstein was familiar as a recognizable form of political manipulation within the context of the political mores of the ruling classes of the time. Several exemplary texts of Roman history include, moreover, specific commentaries on incest and power, and thus provide information on the learned messages that the female ruler-to-be, Duchess Louise of Liegnitz, Brieg, and Wohlau, might have received as she considered the play that contained such explicit scenes of eroticized behavior between mother and son.

\section{Semiramis and Agrippina: Matricide in the Margins}

The incest scene in act 3 of Lohenstein's Agrippina is prominent among the reasons why the play as a whole has been most criticized. In it, the queen mother is shown using both her physical attractiveness and a kind of seductive learnedness and sophistication in affairs of state to seduce Nero. ${ }^{19}$ The scene "produces" the seduction with great attention to physical detail. Arousing him with the promise that the fire that her lips have set can be cooled off only in "der glatte Schnee der Schooß" (new snow of her bosom [or lap]) (61, 1. 141), Agrippina responds, in answer to Nero's desperate protests that he would indulge but for the fact that this same "Schooß" had carried him for nine months (1. 146), with an argument familiar from much contemporary theory of Staatsräson; she argues that legal and moral injunctions against incest apply only to lesser mortals, and certainly not to Caesar (1. 164). Moreover, should her son need some sort of legal frame for succumbing to a mother's wiles, Agrippina cites a precedent: "Der Persen Recht läßt zu: daß eine Mutter sich/Ins Sohnes Bette lägt" (Persian law permits a mother to betake herself to her son's bed) $(62,11.207-8)$. The beginning of the textual trail that ultimately leads to Semiramis and her annotational afterlife in the early modern period begins here. Just prior, however, to tasting the final fruits of both her words and her deeds, as Agrippina says (63, 1. 236), deeds that have already driven Nero to fall trembling, pale, but burning with passion upon her breasts, the queen mother's plans are disrupted by the entry of her son's mistress, Acte. Sent by Seneca and Burrhus to prevent Nero from falling into the clutches of the woman whose "Regiersucht" (addiction to ruling power) $(59,1.90)$ Burrhus claims has motivated this shameful behavior, Acte inhibits its fulfillment.

As shocking as the explicit nature of this scene might seem, there is no indication in the Szenare that it was not played as it appeared in the printed text published the previous year. ${ }^{20}$ And indeed, as was probably the case for the production of Epicharis, any number of props, such 
as papier-mâché breasts, could have contributed to the illusion that it was really a powerful, indeed (from a political perspective) threatening woman whose only partially clothed body dominated this scene. Surprisingly, however, it is the printed version, with its dense annotations and learned apparatus, that points most convincingly to the historical feasibility of the scene, with its focus on the woman and queen mother as sexual protagonist. Lohenstein's notes contain traces of the playwright's familiarity with the complexities of a similar case of maternal incest on the part of another female sovereign, namely Semiramis, whose sexual habits were the object of conflicting evaluations about the moral propriety and political legitimacy of a woman ruler's behavior.

Before proceeding to an analysis of Lohenstein's references to the Persian Semiramis, however, it is important to recognize that Agrippina's political profile is made to emerge in Lohenstein's play precisely in the context and as a result of her sexual behavior in this very scene. In one of the playwright's sources, namely Tacitus's Annals, the historian explains that the texts he consulted admit of uncertainty as to whether it was in fact Nero or Agrippina who took the initiative. ${ }^{21}$ The detail is significant. The lack of clarity as to whether Agrippina was using sex as a means to retain power, because she had fallen into disfavor with her son, "seu concepit animo tantum immanitatis" (or whether the enormity was actually conceived in [her] brain) — not surprising in a woman whose reputation for infamous sexual behavior was well known-indicates the apparent lack of a conclusive stance in the ancient sources on the queen's political culpability. In Lohenstein's play as performed text, the scene would appear to follow Tacitus in leaving the issue of motivation ambiguous. Agrippina stands accused by third parties of political manipulation. Yet she insists - as she must, in order to remain innocent of the charge of treason-that she approaches her son in an erotic way because of a kind of spontaneous, indeed uncontrollable desire. The published notes, however, specifically on the reference to Persian law at line 207, indicate the parameters of the immensely complex debate among historians and political commentators about the connections between intrigue and desire, connections that suggest that Lohenstein intended to cast the scene as a planned act of political seduction. The specifically political origins of Agrippina's attempt at incest pointed to in the glosses suggest the playwright's apparent desire not to condemn the queen mother outright for her sexual initiative as an issue of morality, but, rather, to ultimately excuse her on political grounds; or, if that is too strong, the notes at least indicate Lohenstein's conviction that Agrippina's deployment of seduction as a political tool is not to be declared the expression of a perverse sexuality or even "politische Prostitution" 
(political prostitution), as Just has maintained, but evaluated, rather, in terms of whether it was ultimately politically effective or not. ${ }^{22}$ The work of philology thus allows us to read Agrippina's reference to Persian law as an indication that the play was addressing issues of political pragmatism rather than simply representing a powerful woman's moral turpitude. Given the similarities between herself and the stage Agrippina, Duchess Louise may have been just as, if not more, interested in these issues than in the particularly perverse "family values" of the seduction.

Halfway through the incest scene in Lohenstein's play, Nero rejects Agrippina's suggestion of the possibility of an alternative culture, namely that of the Persians, in which the mother-son copulation she suggests is legally sanctioned. He retorts: "Viel/was der Perse lobt/ist bey den Römern Sünde" (Much that is praiseworthy for the Persians is considered a sin by the Romans) $(62,1.210)$. Paradoxically, the moralizing tone that characterizes the immoral Nero here accords nicely with the position taken by many critics who condemn Lohenstein's Agrippina for attempting to seduce her son. Yet such a position may not have been in harmony with the stance of the play, for when we turn to the notes, we find Nero's statement about the illegitimacy of Agrippina's reference to Persian precedent glossed in the following way: "Hiervon redet die gantze Praefatio Aemilii Probi" (This is the topic of the entire preface of Aemilius Probus) (126, 1l. 57-58). This brief reference contains the key to an intertextual disagreement with and self-distancing from Nero's condemnatory claim.

Lohenstein's citation in his notes of the "preface" by Aemilius Probus refers to the opening chapter of Cornelius Nepos's De Excellentibus Ducibus Exterarum Gentium (On the great leaders of foreign lands) (first century в.C.E.), a collection of biographies of famous men, attributed by some until the beginning of our own century to the compiler, Aemilius Probus. ${ }^{23}$ Nepos's preface refers, however, not to Persian customs, as Nero's remark in Lohenstein's play suggests, but to those of the Greeks. That is, in announcing the topic and method of his book, Nepos states that the customs of Greek civilization - in contrast to those of Romeprove the reality of cultural variety and thus the relativity of moral judgment. Cimon of Athens married his "sororem germanam" (sister by the same father), for example. Nepos argues: "[Q]uippe cum cives ejus eodem uterentur instituto" ([B]ecause his fellow citizens used the same practice), the act was not considered a disgrace, although Roman custom would judge it as abominable indeed ("At id quidem nostris moribus nefas habetur"). Conversely, many Roman practices held to be "decora" (proper) "apud illos turpia putantur" (are considered sinful among other cultures). Thus not all peoples find the same acts to be 


\section{Agrippina}

good or evil, Nepos writes. By and large, he concludes, the rule of thumb must be that of convention and of "majorum institutis" (the practices of one's ancestors), which are themselves determined by specific political and social needs, as Nepos's series of biographies of foreign generals goes on to show.

Although it is not obvious that Lohenstein necessarily agreed with Nepos's stance in the preface to his lives of famous leaders, the fact that he cites this text in his notes specifically within the context of the incest suggests that Agrippina's argument about a Persian precedent for the permissibility of incest was, at the very least, a recognizable position in a debate about the relativity of cultural values conducted among ancient historians and biographers, and thus neither unique nor the outrageous product of her depraved mind and body. In at least some of the numerous early modern commentaries on Nepos's text, moreover, there is a striking fascination with cataloging additional examples of cultures in which precisely the incestuous aspect of the Greek Cimon's alliance with his sister is considered legitimate. ${ }^{24}$ There is every indication that Lohenstein used several of these commentaries in composing his play, because their notes (rather than the primary texts) contain the textual origins of the incestuous Persian mothers whom Lohenstein's Agrippina cites. The position that Agrippina espouses - namely, that there are cultures in which incest is permissible - can thus be documented to have been well known and perhaps even acceptable to some scholars at the time.

In the edition of Nepos's Lives published by Augustinus van Staveren in Leiden in 1734, for example, the annotations written by numerous earlier humanists are excerpted, compared, and contrasted in an elaborate annotational apparatus at the bottom of each page. Here we have access to the universe of terms included in the debate about power, gender, and morality with which Lohenstein would have been familiar as he wrote his play. The notes on Nepos's "Praefatio" are extensive, often spilling over onto the page after the one on which the line to which they originally refer is located; the main text is thus crowded into a small sliver at the top of the page. The note in the van Staveren edition to Nepos's story of Cimon and his sister is no exception; it is lengthy and contains selections of glosses by scholars working in Lohenstein's day. ${ }^{25}$

Of particular interest in this context is the part of the van Staveren note attributed to "Ernstius"; the reference is to Heinrich Ernst, or Ernesti, of Helmstädt (d. 1665), who published a volume of learned reflections on Nepos's Lives in 1637. ${ }^{26}$ Ernesti glosses the "nefas" of Nepos's statement that the incest permitted in Greek culture is considered a crime by the Romans with an intensification- "Id est, turpe" (that is, morally dis- 
honorable). Yet, he also cites Theodoretus and Tertullian to the effect that other peoples, including, not surprisingly, the Persians, allowed mothers, sisters, and daughters to "mix with their own" (suis miscebantur). If Lohenstein had been using an edition of Nepos either edited by Ernesti or an earlier version of an edition like van Staveren's 1734 variorum Nepos containing excerpts of Ernesti's remarks, it is easy to explain why he (Lohenstein) can cite Probus ( $=$ Nepos) in his own note to Agrippina's claim about the Persians, because the Persian connection would have jumped up at him out of the margins of the page. That is, although Nepos himself talks only about the Greeks and the Romans in his, the main text, and thus had nothing to say about Persian customs at all, Lohenstein would have found the connection between Romans and Persians in Ernesti's notes in the Nepos edition he used, annotations that were in any case typographically more prominent than the original text. The humanist desire to document and assemble reference upon reference to the "aberrancies" of ancient custom and habit may thus have ultimately had the effect of bringing some readers, including Lohenstein, around to Nepos's - and indirectly, Agrippina's - point of view. Confronted with the textual reality of numerous cases in which incestuous behavior considered illegal, immoral, and reprehensible by one culture was documented as acceptable, even common, to another, the possibility of the kind of cultural relativism for which his Agrippina argues would have become difficult for Lohenstein to ignore.

The note on Nepos's Cimon in van Staveren's 1734 edition that contains Ernesti's 1637 mention of the Persians ends with a reference to other places where additional information can be found about customs accepted not among Nepos's original Greeks but, rather, among the apparently more popular Persians and "eastern peoples" (Persarum [et] Medorum morem acceptum). Not surprisingly, the note concludes with a specific reference to mother-son incest: "V. [et] Brissonium de regno Persarum L. 2. p. 229. laudatum a Cl. Haverkampio. Hunc Persarum [et] Medorum morem acceptum refert Semiramidi Conon Narr. 9 apud Photium Biblioth, p. 428, 429. Ubi vide, quae de hoc more notantur ab interpret" (See also Brisson's De regno Persarum, book 2, p. 229, cited by Cl. [?] Haverkamp. Conon's ninth tale in Photius's Bibliotheca, p. 428, 429, attributes this accepted custom of the Persians and the Medes to Semiramis. See the commentator's observation about this custom in his notes to the passage). This note refers explicitly to the story of Semiramis and her young son, Ninus, for whom she ruled. Both the French statesman Barnabas Brisson (1531-91) and the pompous but learned Dutch professor Jacob Gronov (1645-1716), who also published under the name of Gerhard Haverkamp, were obviously familiar with the Semiramis 
story and had commented on it; it is their commentaries that the van Staveren edition cites. ${ }^{27}$

Although van Staveren's Nepos was published some seventy years after Lohenstein wrote his play, it contains commentaries like Ernesti's, Brisson's, and Gronov's available in the first three quarters of the century and thus reflects the level of learned debates about such topics among central and northern humanists at the time Lohenstein wrote. On the basis of this discussion, it seemed logical to van Staveren-as it may well have seemed to Lohenstein, who would have used similar editions and been familiar with this same tradition of commentary - to think of the specific case of the Persian Semiramis in connection with a case of Roman incest, probably because it was mentioned so often in these learned texts. It may have been this connection that caused Lohenstein to link his Agrippina with the Persians in general at lines 207 and 210 of his play, and with Semiramis in particular some one hundred lines later.

Agrippina is not the only one to be concerned with the question of the acceptability of incest in Lohenstein's play, however. One hundred lines after she cites the precedent of mother-son incest in "Persian law," Nero's duplicitous advisor Anicetus, for example, also describes the attempt at seduction with an explicit reference to Semiramis, who was also, he claims, a lascivious and ambitious mother $(65,11.310-11)$. This time, however, the reference is designed to move Nero away from sex and in the direction of matricide. Anicetus's remarks suggest, first of all, that Agrippina is guilty of political intrigue and, second, that if she would act the role of Semiramis, he (Nero) must fulfill the terms of the comparison and "legitimately" kill his mother, as Ninus (Semiramis's son) is said to have done. What version of Semiramis's story is Anicetus referring to, and where does Lohenstein stand on the question of the comparison's legitimacy? Indeed, even if the comparison is a fair one and Agrippina's gestures are part of a plan to undermine her son politically, does Lohenstein's text endorse Nero's subsequent "imitation" of Ninus, who in some sources is said to have murdered his mother? Or does it offer an alternative to Anicetus's scenario?

The tradition of representations that would favor Anicetus's negative judgment of Semiramis is available, again, in a text such as Boccaccio's Concerning Famous Women. ${ }^{28}$ There, Semiramis is described as having ruled for her son in his minority after the death of his father, the king of Babylon. As clever as she was beautiful, and fearing that a woman might not be obeyed, she contrived to be taken for her son-they were similar in build, Boccaccio says-by "inventing" the style of dressing that came to be popular for the entire country, "masking her sex" (mentita sexum) with a turban and baggy leggings, or pants. Ruling the coun- 
try and doing deeds remarkable even for men, she soon found herself in a secure enough political and military position to reveal her true sex. In the process, Boccaccio comments, she had convinced her people that ability, rather than biology, was of greatest importance in a leader. The only spot on Semiramis's illustrious life and career-but a spot capable, Boccaccio claims, of wiping away the memory of anything praiseworthy she had done-came when she, "obscena mulier" (obscene woman), succumbed to a lustful passion for her son, and thereby established the permissibility of mother-son incest. Ninus, enraged by her advances, or by jealousy, or by fear that children might be born as a result of the deed, is said, in Boccaccio's account, to have murdered her after thirtytwo years of rule. His reaction was understandable, Boccaccio's commentary implies, since her lust eradicated any positive memory of her earlier deeds.

Lohenstein's Anicetus obviously shares Boccaccio's misogynist assessment when he cries: "Sie [Agrippina] hat den Halß verwirgt nur durch die bösen Lüste./Des Ninus Faust durchstach der geilen Mutter Brüste./ Wil sie Semiramis/muß Nero Ninus seyn" (She has brought on her own destruction only by means of her evil carnal pleasures. Ninus pierced his lustful mother's breasts. If she [Agrippina] would be Semiramis, Nero must become Ninus in turn) $(65,11.309-11)$. And yet, Lohenstein's notes on Anicetus's depiction of Agrippina as a new Semiramis make it clear that he was familiar with other, more positive assessments of Semiramis's career than those articulated by either his character or Boccaccio. These notes indicate that he would have his readers bear in mind a version of her story that goes beyond the one presented by Anicetus. By calling attention to this alternative version and thus the wider context of the act of incest, Lohenstein's notes suggest that Anicetus's remarks should be understood as partial in the many senses of the word. Semiramis's other accomplishments and their similarity to Agrippina's achievements become more visible as a result.

In his gloss on Anicetus's reference to Semiramis, Lohenstein writes: "Von der grossen Königin zu Babylon Semiramis ist bekandt: Daß sie ihr Sohn Ninus/welchem sie Bluttschande angemuthet/getödtet habe. Justin. lib. I" (It is well known about Semiramis, the great queen of Babylon, that her son, whom she had encouraged to commit incest [with her], killed her. Justinus. Book I) (126, 11. 59-61). The "Justinus" whom Lohenstein cites here is Marcus Junian(i)us Justinus, who wrote a thirdcentury epitome of the Augustan historian Pompeius Trogus's Historicae Philippicae (Philippic histories). Lohenstein's note continues to the effect that Semiramis is also said by some to have turned into a dove at her death, thus explaining the tradition that Babylonian standards and 
flags always depicted that bird. The reference here reads: "[W]ie aus Diod. Sicul. Athan. Kircher. Oedip. Aegypt. tom. 2. part I. c. 3. p. 26. anführet" ([The Jesuit humanist] Athanasius Kircher [1602-80] cites from Diodorus Siculus [Diodorus of Sicily] in his [Kircher's] Oedipus Aegyptiacus [1652], volume 2, part 1, chapter 3, p. 26) (126, 11. 63-64). The reference to Kircher on Semiramis might seem extraneous, except that precisely its juxtaposition, in the very same note, with the reference to Justinus and his commentary on her crime of incest makes us wonder why the Babylonians would have honored the memory of so depraved a queen by adopting her symbol as their mascot. ${ }^{29}$ Indeed, the very form of the gloss - with its textual enactment of the tradition of competition between annotational traditions - makes us ask in what respect Semiramis's vexed reputation was produced by a commentary tradition split over the issue of whether to praise or condemn her sexual acts. Both Diodorus's and Justinus's versions, versions that Lohenstein's references to them indicate that he knew, answer this question by pointing to the existence of a very different Semiramis than Boccaccio's, a Semiramis that Aniectus would appear to want to ignore or suppress.

Diodorus of Sicily's story of Semiramis is the lengthiest and most detailed rendering of the deeds of the woman whom he calls " $\tau \grave{\eta} v$ $\dot{\varepsilon} \pi \iota \varphi \alpha v \varepsilon \sigma \tau \alpha \dot{\tau} \tau \eta v \dot{\alpha} \pi \alpha \sigma \widetilde{\omega} v \tau \widetilde{\omega} v \gamma \nu v \alpha \iota x \widetilde{\omega} v \tilde{\omega} v \pi \alpha \varrho \varepsilon \imath \lambda \eta \dot{\varphi} \varphi \alpha \mu \varepsilon v^{\prime \prime}$ (the most renowned of all women of whom we have any record) (2.4.1). ${ }^{30}$ He tells the history of her rise to power through marriage to Ninus (father of

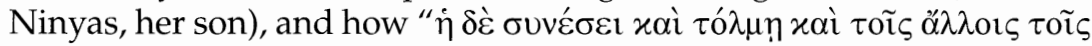

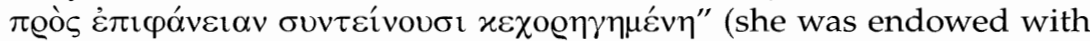
understanding, daring, and all the other qualities which contribute to distinction) (2.6.5). The story of her invention of the sex-masking Persian garb is told here not in association with her regency for her son but in connection, rather, with her talent for military analysis and strategy (2.6.6-7); it thus does not strike the reader as a surprise when she subsequently inherits the kingdom upon Ninus's demise (2.7.1). Tales of her building projects in Babylon, military exploits, and feats of engineering skill go on to fill some sixteen long chapters of Diodorus's narrative; her sexual preferences are mentioned only in passing, and contextualized

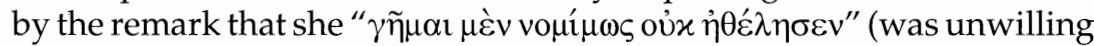
... to contract a lawful marriage) with any of her lovers not because

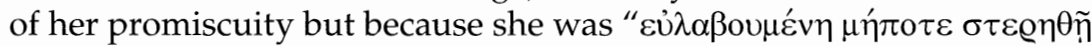
$\tau \tilde{\eta} \varsigma \dot{\alpha} \varrho \chi \tilde{\eta} \varsigma^{\prime \prime}$ (afraid that she might be deprived of her supreme position) (2.13.4) if she did.

Diodorus makes no mention of incestuous activity with Ninyas; to the contrary, his account states that the revelation of a court conspiracy against her, undertaken on her son's behalf, but carried out by one of his 
eunuchs, ultimately causes Semiramis to abdicate and turn the kingdom

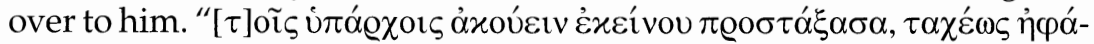

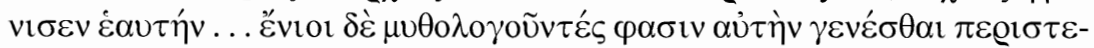

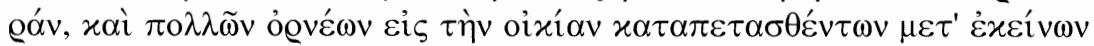

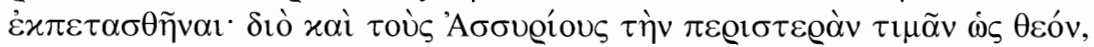

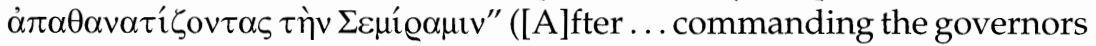
to obey him [Ninyas], she at once disappeared.... Some, making a myth of it, say that she turned into a dove and flew off in the company of many birds which alighted on her dwelling, and this, they say, is why the Assyrians worship the dove as a god, thus deifying Semiramis) (2.20.1-2). This is the detail that Kircher picked up, and that Lohenstein repeated in turn, a detail, however, that points to the alternative story of her end in Diodorus's account and to the lengthy account of her illustrious career that precedes it. Like the careers of Dido or Sophonisbe, strong female leaders both, Semiramis's career was associated in this version not necessarily with incest but rather with the work of a wise, powerful, and respected queen. ${ }^{31}$

Diodorus's Greek World History dates from the first century в.C.E. His is the lengthiest and best-known classical version of Semiramis's story, a story in which it would have been difficult to find a reason to censure the queen, particularly in terms of her sexual behavior. Many of the other classical sources on Semiramis, from Herodotus's brief reference in the fifth century B.C.E. through Plutarch (50-120 C.E.) and Claudius Aelianus (second century c.E.) likewise mention her only in terms of her achievements and political acumen, which in some versions allow her to outwit her husband and take over his kingdom..$^{32}$ Thus, when in his third-century portrayal of the Assyrian queen - the other version Lohenstein cites-Justinus represents Semiramis in a positive light, we may assume that he turned to Diodorus as well as to the others as sources for the Persian queen's achievements.

In Justinus's Epitoma Historiarum Philippicarum Pompei Trogi (Epitome of the Philippic histories of Pompeius Trogus), Semiramis's life is told in rather shorter fashion than in Diodorus's History, but there is a similar emphasis on her achievements as a political leader. ${ }^{33}$ The story of her transvestism occurs here in connection with her regency for her son; Boccaccio probably found it here. Wisely considering the difficulties that even her husband, a man ("Nino viro"), had ruling such diverse peoples ("tantis gentibus") (1.2.1), she concludes that she as a woman would have even less success, and thus dresses herself and her people in the loose, unisex garb, achieving "magnas ... res" (great things) thereafter, as Justinus writes (2.2.5). When she finally reveals her true sex, moreover, no one takes it amiss. Indeed, her reputation even increases, 
he continues, because it becomes clear that, precisely as a woman, she has surpassed not only all other women but men as well (1.2.6). She founded Babylon, led wars of conquest, and died, he concludes, murdered by her son, when she sought sexual intercourse with him ("cum concubitum filii petisset, ab eodem interfecta est") (1.2.10) after thirtytwo years of rule. Not mentioned in the accounts by Herodotus, Plutarch, and Aelianus, the source of Justinus's story of Semiramis's attempted incest with her son is unclear. In any case, it is presented in his text as a matter of historical record, nothing more. Justinus's overall assessment of the queen's behavior is positive and thus very different, as Irene Samuel shows, from the condemnations to which later, medieval writers, such as Augustine, Orosius, and Jerome, subjected her in their texts. These texts were based on Justinus but are radically different from him in tone. ${ }^{34}$

In his notes to Anicetus's condemnation of Agrippina as following Semiramis's model, Lohenstein omits any references to Augustine, Orosius, or Jerome, even though he could have been introduced to their versions in the marginalia of contemporary editions of Justinus. The absence of their negative versions of Semiramis's career is striking, because including them would have allowed him to underscore and legitimate Anicetus's claims. But they are not named. Rather, the playwright refers only to Justinus and Diodorus in his notes. By calling attention to their versions of the legend rather than to the condemnatory remarks by the church fathers, Lohenstein leaves the reader with the image of a strong and politically savvy Semiramis, whose reputation the accusation of incest could do little to tarnish. In the context of these annotations, Anicetus's remark about the two women's common depravity thus becomes suspect, particularly if we look to seventeenth-century editions of Justinus, texts edited and published with annotations by scholars whose work Lohenstein is known to have valued. These editions make clear that the tradition of late humanist commentary with which Lohenstein would have been working when he referred to Justinus as his source for the Semiramis story saw not the act of incest but, rather, Ninus's murder of his mother as the paramount crime. In the context of a play that dwells on the slaying of Agrippina by her son, the parallels could not be more apparent; indeed, they suggest that the playwright sought to shed light not on the questionable sexual behavior of the mother but rather on the reprehensible actions of the murderous son. It is perhaps for this reason that the frontispiece of the play depicts the horrific scene of matricide rather than the titillating moment of incest (see Figure 5) as the main event of the play. 


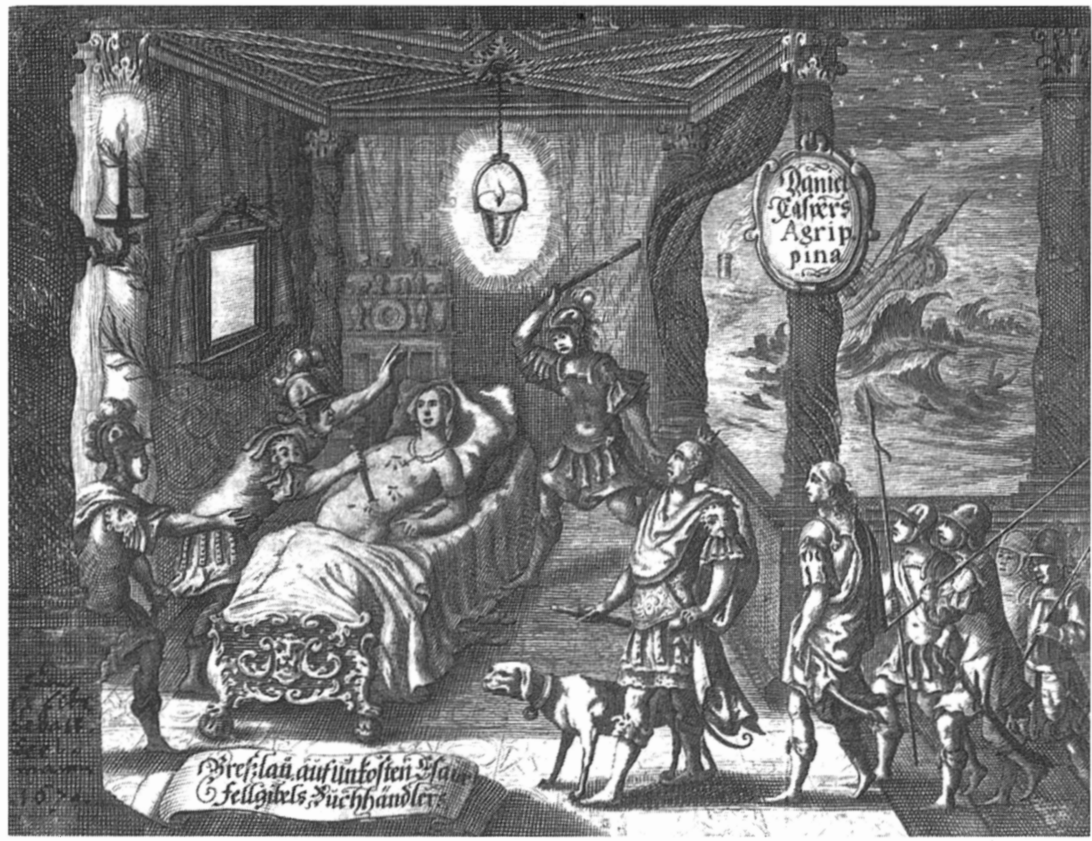

Figure 5. Lohenstein, Agrippina (1665). Reproduced with permission of the Bayerische Staatsbibliothek, Munich, Germany.

In the edition of Justinus edited by the Straßburg professor Matthias Bernegger and printed in 1631, for example, Diodorus's version of Semiramis's life, along with Plutarch's and Aelianus's, which highlight the clever way in which she usurped Ninus's throne, are referenced in the notes to the final line of Justinus's book 1, chapter 1, when Semiramis's name is mentioned for the first time ${ }^{35}$ Lohenstein also used Bernegger's Justinus commentary in his play about Sophonisbe. ${ }^{36}$ We can surmise that he used this edition in composing the Agrippina as well. More significant, however, are Bernegger's remarks at the end of chapter 2 of Justinus's Histories, where the fact of Semiramis's incest and the subsequent matricide are discussed. Bernegger begins his gloss on the line "ab eodem interfecta est" (by him [Ninus son] she was killed) with emphatic disapproval: "Injuste" (unjustly, with no right), he cries. ${ }^{37}$ The note begins with citations by title and chapter of the texts by Orosius and Augustine in which Semiramis's lustful character is condemned, it is true; but it ends with a string of references to the classical authors, including Herodotus and Plutarch, for whom it was her political shrewdness rather 
than her sexual behavior that distinguished her. The implication here is that Semiramis's reputation as a leader outweighs the accusation of incest, the stance that Justinus in fact held. The very form of the gloss indicates, moreover, that Bernegger agreed with him. An accomplished legal theorist and man of state like Bernegger would have known, that is, that the mos italicus of dialectical argumentation usually called for presenting the case to be refuted first. ${ }^{38}$ Thus the church fathers' condemnations of Semiramis were to be left behind; Herodotus and Plutarch get the last word in the gloss.

Bernegger also calls attention in his gloss on this line to his remarks somewhat later on in Justinus's text ("Infra, 16, 1, 4"). When we turn to Justinus 16.1.4, we discover that the issue being discussed there is parricide, for which, Justinus declares, there is "never enough just cause" (quanquam in parricidio, nulla satis iusta causa), regardless of whether it is politically expedient or not. ${ }^{39}$ Bernegger's commentary is lengthy and explicates other famous incidents of parricide. Questions of immorality and political expediency are, of course, ultimately what is at stake in the scene of incest in Lohenstein's Agrippina, the scene to which the entire discussion of Semiramis refers. But in Bernegger's notes on Justinus, the matricide Ninus, and not Semiramis, commits the more egregious immoral act. He kills her "unjustly." Against the background of Bernegger's glosses, which Lohenstein almost certainly knew, the play's reference to a Ninus-like Nero and a Semiramis-like Agrippina suggests that the playwright may have understood them as representatives of negative and positive political and moral behavior, respectively. Nero's killing of Agrippina is thus implicitly condemned more than Agrippina's seduction of her son.

Other editions of Justinus available when Lohenstein was writing $A g$ rippina contain Bernegger's glosses and even supplement his (Bernegger's) understanding of the Semiramis story with still more material derived from other ancient sources..$^{40}$ Like Bernegger, so too these other commentators understood the act of incest engaged in by Semiramis to have beerr undertaken not by a lust-crazed woman blinded by desire but, rather, by a powerful queen seeking to preserve her power in a skillful, if perhaps (from our perspective) somewhat unorthodox way. It may well have been either to editions such as these or to a volume containing notes by Bernegger alone that Lohenstein thought he was referring his readers when he cited Justinus's rendering of her story in his notes on Ninus's deed at line 310. And, if his Agrippina were indeed as similar to Semiramis as Anicetus's remark suggests, she would have been following the model of a woman considered by at least one tradition of early modern commentary not as a promiscuous hussy but as an 
example of a powerful ruling woman, a "femme forte." Lohenstein's learned glosses thus ironize Anicetus's claim by citing a commentary tradition at odds with it. The horrific aspect of an immoral play dominated by an oversexed queen mother preying upon her helpless son loses quite a bit of its threat when seen in this light. Or, if that is too strong, then the play asks that Agrippina's actions vis-à-vis Nero be judged from a political rather than from a moral perspective. Observing the actor playing her character from this point of view may well have appealed to Duchess Louise precisely as the staging of a ruling woman's political options.

\section{Women in Power: Gender Stereotypes and the Politics of Philology}

The matter-of-fact perspective from which both Justinus's version of the Semiramis story and a number of other seventeenth-century commentaries on it consider the event of mother-son incest begins to suggest how Lohenstein's depiction of a seductive Agrippina could be understood as a potentially sympathetic one, indeed, how she can come to occupy a position endowed with almost positive value at the end of the play, when her spirit "haunts" a cowed Nero, who, in a standard neoSenecan moment, resorts to sorcery in an attempt to appease her. ${ }^{41}$ The portrayal of Agrippina in an intertextual vocabulary of the unjustly wronged in act 5 occurs in spite of or, perhaps better, exactly as a result of the scene of attempted incest in act 3. For a powerful woman acting according to Semiramis's model, political circumstances often dictated that actions perhaps not permissible in other contexts be undertaken in the interest of acquiring or maintaining power. Somewhat further on in the van Staveren variorum Nepos discussed earlier, in a gloss on the Roman custom of women's appearance at public banquets, a note by one Johann Heinrich Boecler, quoted from his 1640 reflections on Nepos, articulates this stance. Boecler registers his recognition of the practical implications of Nepos's acceptance of the principle of cultural relativism: "Nihil autem dubitaverim afferere [sic]: Nepotis testimonio, de more universe accepto, nihil detrahere, quae haud dubie diversa personarum, locorum, temporum, ceterarumque rerum, quibus consuetudines aliquam dissimilitudinem aut exceptionem patiuntur, conditione aliter acciderunt" (Moreover I would hesitate to add or take away anything from Nepos's commentary [here] about generally acceptable custom, [since] without a doubt the practices of people, places, times and certain things occur otherwise [because of] diverse circumstances) ${ }^{42}$ 
In other words, if the particular historical situation warrants it, behavior very unlike that which one might expect could be deemed acceptable. This appears to have been the case in Semiramis's relationship with her son, and indeed, in Agrippina's incest attempt as well.

Boecler belonged to the group of German philologists and historians active in and near Straßburg and Heidelberg, a group that included Bernegger and others, whose humanist learning was more often than not deployed in the service of the practical politics of the day. ${ }^{43}$ Their editions of the Roman historians dominate Lohenstein's notes when he refers with specificity to the editions he used. Although separated from this group by a generation or so, he could have shared certain political values with them, including support for local rulers with Calvinist sympathies (in the Rhineland for Boecler and the others, in Silesia and at the Piastian court for Lohenstein). Such parallel circumstances could have made these early and midcentury commentaries resonate with useful insights for the playwright and might explain the consistency with which these specific versions of the classical historians, particularly Tacitus, are cited in Lohenstein's notes. Full of both concrete references as well as asides designed to reflect on contemporary political issues, these commentaries recognize that as personnel and power constellations change in a given political context, so too do the standards for judging right and wrong. Indeed, as Boecler writes elsewhere, the study of history demonstrates that "[m]utatur [et] variatur ipsa honesti natura" (the very nature of virtue changes and varies) ${ }^{44}$ The example of incest among the Persians may have been a case in point. If, moreover, circumstance can justify or at least explain what might seem to be aberrant or idiosyncratic behavior as politically motivated, Agrippina's recourse to attempted seduction in order to protect herself and her power base from deteriorating in the face of opposition from Nero's counselors could be understood as neither so strange nor so much the product of a particularly lustful or ambitious woman after all. Rather, like Semiramis in at least some versions of her story, the queen mother was simply using sex to retain power, a perfectly predictable and pragmatic act given the labile political situation she faced.

In his development of the materials for his play about Agrippina, Lohenstein probably referred to an edition of Tacitus prepared by a member of the Rhineland group, one Christophorus Forstner, a well-known political advisor to the house of Montpelier and representative to the peace conference after the Thirty Years' War of $1648-49 .{ }^{45} \mathrm{He}$ cites Forstner's commentary on Tacitus's Annals nine times in his notes to his other "Neronian" play, Epicharis; we can assume that he also had this edition in mind, if not on his desk, as he wrote Agrippina too, which was pub- 
lished in the same year and produced on alternate days with Epicharis for two weeks in May 1666. Forstner's notes on Tacitus are important to understanding Lohenstein's portrayal of Agrippina as a female ruler, especially if we keep the example of Semiramis in mind. By "excavating" the several sites of Tacitean material in Agrippina, we can hear the echoes of Forstner's philology in Lohenstein's play as they might have fallen on interested ears in the case of Duchess Louise, especially since she could have expected to be confronted with a similar situation in the years to come. The schoolboy actor playing the role of Agrippina, as well as his fellows watching him act, could have also learned a few lessons about what to expect in terms of sexual-political behavior if they were eventually to find employment in administrative positions at Silesia's smaller courts.

Forstner's notes on the chapters of Tacitus's Annals in which Agrippina's rise and fall are charted reveal where Lohenstein would have found a treatment of the queen mother distinguished above all by its attention to pragmatism, by its recognition, that is, of the realities of court life and of the modes of behavior typical of contexts in which powerful women might be present. ${ }^{46}$ Several lengthy notes address the topic of female regency in some detail; the potential for competition and tension between mother and soon-to-be-of-age son is described with a tone that denotes familiarity with the topic. What is especially striking about Forstner's notes, which would have been obvious to anyone who consulted them in connection with Lohenstein's very specific citations to the Annals by book and chapter in his notes to the play, is the matter-offactness with which he (Forstner) treats Agrippina's behavior as regent. Above all, he acknowledges her as an equal match for the emperor, her son; her talents for and methods of political manipulation and survival seem entirely predictable, sometimes even praiseworthy, given the context. Most significant, when she-and others-resort to sexual intrigue in pursuit of their political ends, Forstner observes that such behavior is typical of courtly realities, both in Rome and in his own time.

Forstner first notes the nature of the difficulties between regentmothers and their sons in connection with Tacitus's remarks in book 12 of the Annals on Agrippina's rivalry with Nero's aunt, Lepida, for her son's favor. Tacitus suggests that Agrippina's ambition ultimately caused her to be "truci ... ac minaci" (fierce ... and full of menace) to her son, since she "[f]ilio dare imperium, tolerare imperitantem nequibat" (was capable of presenting her son with an empire, but not of tolerating him as emperor) (12.64.410-11). Although Tacitus clearly seems critical here, Forstner's note indicates a more impartial position: "Matrum reginarum ingenium!" (Oh, the genius [mode of thinking] of queen 


\section{Agrippina}

mothers!) (Tacitus, 1652, 246), he writes; such a reaction seems predictable to him given the situation and the personnel. The brief note here closes with the suggestion that readers consult Forstner's own earlier remarks on Annals, book 3 ("V. Omiss. ad 3. annal. p. 582"). When we turn to that note, the context, namely Tacitus's account of the relationship between Julia Augusta and Tiberius, reveals that it clearly prepares for Forstner's later position on the Agrippina-Nero relationship, because it documents a prior example of mother-son tensions. "The hatred of prince sons [Principium filiorum ... odia] against their mothers is long standing," explains Forstner's note on Annals, book 3, p. 582. "The lust for power is more passionate than all other feelings," he goes on, such that "queens" (reginae) who are regents or the "keepers of power" (tutelae potestate) actually aim at maintaining their role as "sole ruler" (tyrannidem), "thinking that they should be the heir to the throne rather than the son" (nec tam filium Principem esse, quam se matrem, cogitant). Conversely, "the woman's rank is considered [by the son] a lessening of the power of the prince." This is why, he concludes with a series of examples, so many sons and mothers have been rivals. In the case of Nero and his mother, he comments, the rivalry culminated in his plot for her death.

Seen against the background of Forstner's notes, Lohenstein's Agrippina's desire to maintain power may have been problematic, but would not have appeared unusual or out of place. Indeed, it was probably the result of the same kind of political logic that had motivated Semiramis's behavior as it was analyzed in the histories and commentaries discussed earlier. Forstner's remarks on Annals 13.12, where Tacitus writes of the gradual weakening of Agrippina's hold on her son, indicate in a similar fashion that the relationship between queen regent and prince is by definition fraught with tension. To observe its mechanics on stage might have been a useful lesson indeed. "Rara est Reginarum Matrum usque ad tutelae finem perdurans, nec ullis simultatum nebulis turbata potentia: rarior post depositam administrationem modestia: quam retinere satius esset, quam prorogato in annos, quibus sui juris filius est, imperio offensas accersere. Ita apud Neronem infracta paulatim matris potentia" (It is rare that the power of a queen mother lasts until the end of the regency or that it will not be disturbed by any clouds of rivalry [dissension]; modesty [in a queen mother] after the office [of regent] has been put down is even rarer; it would be more recommended to retain modesty [however] than to bring disfavor upon oneself by [trying to] prolong one's power into the years when the son is his own master. And this was the case with Nero when his mother's power began gradually to weaken) (Tacitus, 1652, 276). The remark is quite clearly directed at women in positions of regency, and seeks to warn them of the conse- 
quences of various modes of behavior. We must bear in mind that the 1652 Forstner volume in which these remarks appear was dedicated to a woman ruler, Queen Christina, and that Lohenstein could have found reason to think of Duchess Louise when he read Forstner's notes. The comment that a queen mother's power seldom lasts out the regency and is even more rarely relinquished with grace indicates that disputes about power were more the rule than the exception in such cases, and that these could happen even before the young prince had reached his majority. Duchess Louise may have paid special attention to this final point.

The manner in which the relationship between Nero and Agrippina is discussed in Forstner's glosses indicates that they were in fact political rivals, caught in a power struggle in which either one of them could win, but not both. We can best understand Forstner's frequent use of the Latin term, princeps, when referring to Agrippina (see his notes on 14.3 and 14.6, for example, in Tacitus, 1661, 7-8 and 14, respectively) in light of such an assessment of her role; she functions at this point in her relationship with Nero as a "rival chief," as if she were herself in line for the throne. She had already demonstrated her talent for ruling and could point to an impressive list of accomplishments; Forstner makes special note of Agrippina's "artes observandae" (skills of observation) in his comments on Tacitus's description at Annals 12.41 (Tacitus, 1652, 203-6) and of her careful removal from positions of influence of anyone who favored Britannicus over Nero as Claudius's heir. Whereas Forstner's gloss mainly recapitulates all the tricks by which she made her son seem legitimate in the people's and the military's eyes, Forstner himself seems to possess a kind of admiration for the woman who could "produce" this particular political coup with such success. Her power was recognized by many, he recounts, particularly those in the colony named after her, and is "ad nostram usq[ue] aetatem celebrata" (celebrated even to our day) (204).

Agrippina's acknowledged proficiency as a ruler suggests why, moreover, when she begins to lose a grip on power, she would use all possible methods to regain it. One of the methods of political manipulation attributed to Agrippina in the course of her long career was, of course, seduction. In the context of his discussion of the alleged incest with Nero, Tacitus mentions that Agrippina is said as a girl to have allowed herself to be seduced by Lepidus "spe dominationis" (in the hope of winning power) (14.2.108-9). She is also reputed to have secured Nero's succession to the throne by means of her infamous marriage with Claudius, her uncle. It is thus no surprise that she uses a combination of these methods - incestuous sex-when attempting to retain power visà-vis her son. 
Again, Tacitus writes that his sources are divided on the issue of Agrippina's incestuous relationship with Nero. Cluvius claims that Agrippina was so "eager to retain her influence" (ardore retinendae. ... potentiae eo) that she "offered him her person" (offerret se saepius ... incesto paratam); Fabius Rusticus, however, "non Agrippinae, sed Neroni cupitum id memorat" (tells us that it was not Agrippina, but Nero, who lusted for the crime) (14.2.108-9). Although Forstner does not take sides in the dispute about sources that Tacitus describes, his notes clearly suggest that he prefers the accounts of Cluvius who claimed that it was in fact Agrippina who initiated the sexual encounter with her son. Yet, these same notes indicate, we must not be shocked or accuse her of abnormal sex drive and perverted lust. For, as Forstner writes in his gloss of the entire discussion of incest: "Retinendae vel quaerendae potentiae instrumentum, adulteria, [et] stupra, alibi (a) notavi" (I have noted elsewhere (a) that adultery and debauchery are the means of seeking or retaining power) (Tacitus, 1661,7). The note must refer to Agrippina's methods, since Nero is in fact in power at this point, and thus would need to neither "seek" nor "retain" it. The note to this note, referred to by "(a)" in the gloss just cited, directs the reader once again back to Forstner's comments on Annals, book 3, where the sexual disgraces of Lepida are discussed (3.22-23).

Earlier in the section on Agrippina and her relationship with Claudius (12.7), moreover, Tacitus in fact indicates that Agrippina was not particularly unchaste. Although it was well known that she seduced her uncle, once she gained power through her marriage to him, "palim severitas ac saepius superbia" (there was sternness and generally arrogance in public) and "nihil domi inpudicum, nisi dominationi expediret" (no sort of immodesty at home, unless it conduced to power). Forstner remarks briefly: "Vide quae infra ad hunc librum notabimus" ([S]ee my comments below on this book) (Tacitus, 1652,130) and refers to his own notes to 12.25, where Agrippina's use of her lover, Pallas, as a tool in the promotion of Nero is discussed. There, Forstner comments, "Veneficia, stupra, adulteria, potentiae sive quaerendae sive servandae instrumenta" ([P]oisonings, unchastity, and adultery are the instruments of seeking or retaining power) (Tacitus, 1652,168), and refers again to his notes on Annals, book 3. The unadorned comment, reiterated at these several points in the narrative (and in an additional comment on the story of Poppaea as well-see Tacitus, 1652, 323-24), that adultery, seduction, and unchastity were standard instrumenta of power politics, by no means suggests that Forstner approved of Agrippina's resorting to sexual intrigue when she found her place in the court hierarchy threatened. But it does indicate that he did not find it unusual, given his fa- 
miliarity with numerous European courts at the time. Agrippina's mistake was thus neither of a moral nature nor a characterological flaw but, rather, one of timing and location, since she had not seen to it that Acte be prevented from interrupting. Nero's counselors were clearly against the queen mother; counselors, as both Forstner and Lohenstein knew from their own experience, must always be cultivated and kept on one's side. Based on assessments of political intrigue like those contained in Forstner's notes on Tacitus, his primary source, Lohenstein's play depicts not the playwright's disapproval of a powerful woman's attempting an incestuous seduction as part of a plan to retain political power. Rather, the stage action plays out the consequences of the failure of such a plan. Duchess Louise might have had good cause to take note of the lessons being taught by - and to-the schoolboys as they mimed the gestures of female lust called for in act 3 .

Much has been written about the role of humanism and its texts in the development of the apparatus and ideology of the Italian city-state of the fourteenth and fifteenth centuries; Stephanie Jed added the dimension of gender to the discussion of philology's role in producing political identity in humanism's heyday. The "political-historical philology" of seventeenth-century central European humanism provides a somewhat different kind of model for the role humanist learnedness played in the construction of both an ideology of gender and of a gendered politics; its encyclopedic, apparently eclectic, but always pragmatic interest in ancient verba was driven by the need to find parallels in the res of past events to function as models for survival behavior amid the complex and unstable realities of the early modern political scene. Early modern gender politics and ideology in central Europe frequently functioned on the basis of precisely such a pragmatics, particularly where the (for us) unexpected realities of female rulership were concerned. Lohenstein's Agrippina testifies to the existence of such realities in Silesia in the mid-seventeenth century and indicates that philology occupied an important position in the artes politicae of the time. Learned women rulers, such as Duchess Louise of Liegnitz, and aspiring schoolboy actors, such as those who acted in these Breslau plays, were in a good position to benefit from the insights into the contemporary discussion among scholar-politicians about political behavior and moral judgment pointed to in the notes. Philology also occupies an important role for us when it lets us in on these discussions as they took place in the "margins" of Lohenstein's play. 


\section{Lohenstein's Cleopatra (1680): "Race," Gender, and the Disarticulation of the Early Modern Imperial Subject}

\section{Discourses of "Race" in the Early Modern Period ${ }^{1}$}

In act 4 of Lohenstein's Cleopatra (1680), the Egyptian queen counsels Caesarion, her son by Julius Caesar, to save himself from the impending Roman occupation of Alexandria by disguising himself as a Moor. With his identity so concealed, Caesarion may slip out of the palace and head south, via Thebais toward Meroë and the source of the Nile, where he will be taken under the wing of Candace, queen and leader of the Ethiopians (116, 11. 373-74). The conceit of Caesarion's Moorish disguise represents a textual innovation in the tradition of early modern Cleopatra plays; indeed, his character is not even included in most well known versions. Yet the suggestion that the young prince follow the river south to escape is based on details that can be found in several ancient renditions of the story of Cleopatra's end. ${ }^{2}$ Lohenstein dilates Plutarch's and Dio Cassius's brief references to Caesarion's fortunes into an elaborate and detailed description of his route south some twenty lines in length (11. 361-80), almost as if to underscore the anomaly represented by this scene, which the playwright in fact added to the play, originally produced in 1661, in his revised version of it published in $1680 .^{3}$ The boy's political profile is particularly evident in Lohenstein's rendering of the story and is figured in this scene of "darkening" (see the next section), which identifies him-and his mother-as resistant subjects, as the anti-Roman, counterimperial and deliberately African forces in the play.

According to the expanded notes that Lohenstein published along with the 1680 version of his Cleopatra, however, the geographical details of Caesarion's escape route are derived not from the classical sourcesDio, Plutarch, Suetonius, and countless others - whose titles clutter the more than 50 pages of notes to this 150-page play, but rather from contemporary texts. The most prominent of these is a travelogue entitled Nouvelle Relation en Forme de Iournal, d'un Voyage fait en Egypte (New account in journal form of a trip to Egypt), which reports a journey to Egypt in 1672-73 by a German, Johann Michael Wansleben (1635-79). Lohenstein gives Wansleben as a direct source for his play some four- 
teen times in the notes; the playwright obviously came across the text as he undertook new research for the updated version of the play. For both Wansleben and numerous contemporaries, whose texts compete for the reader's attention with Lohenstein's references to classical sources in the notes, the origins of the Nile in eastern Africa, the reasons for its annual inundation, and the spectacular biodiversity spawned as a result were objects of great fascination. ${ }^{4}$ Just as interesting to these midcentury scholar-adventurers, moreover, as such geographical details were the complex histories of political, confessional, and cultural ties between Egypt, Ethiopia, and Europe, which are cataloged in these texts with elaborate care; these ties are highlighted by Lohenstein's suggestion of an anti-Roman alliance between Caesarion and Candace.

At first glance, the question of where the German playwright found the origins of Caesarion's journey and the relation of his sources to the figure of Wansleben may appear more or less marginal, in both the literal and figurative senses of the word. Yet, when read in connection with both the innovative "racializing" disguise of the prince and the oppositional stance to Rome that distinguishes his and Cleopatra's political profiles in this play, references to texts by figures like Wansleben become exceedingly rich in significance for a reading of the difference of Lohenstein's treatment of the Cleopatra story from others in the early modern period. I have argued thus far that Lohenstein's plays call for us to read them as implicated in the densely layered textual and material world of their provenance in mid-seventeenth-century eastern central Europe. With its complex web of relations between city, principalities, and the Empire, its transvestite school dramas, its powerful women leaders and learned statesmen, and its multiple traditions of historiography and political theory, this world reveals a version of early modern cultural production that challenges us to reconsider claims that have been made about the period to date. Cleopatra is no different; indeed, it offers perhaps the quintessential example of such layeredness because, alone of all Lohenstein's plays, it was revised by the author in thoroughgoing fashion some twenty years after it was originally produced by the boys, and the second version was authorized by the playwright for publication before his death in 1683. In its supplemental materials, which include substantial increases in the annotational apparatus printed after the play, we can observe at close range the complex textual and geopolitical world of the late seventeenth century as it is registered in a "literary" work that is quite literally "not one" with either the tradition of plays about Cleopatra or, indeed, even with itself. Lohenstein's version of the "race" politics of the period in particular reveals new and deep textual dimensions of his play. 
Like the rest of Lohenstein's plays, Cleopatra reproduces, both as text and on stage, the mobility and heterogeneity of its historical-material origins and its textual sources, matching the complex configurations of political ideology in its own time and place with shifting versions of both ancient history and the well-known story of the Egyptian queen. Like its protagonist, the text has refused to stand still in treatments to date, regardless of how desperately scholars have tried to anchor the play's meaning in one or the other of its versions. The introduction into the learned annotations of 1661 of additional amounts of specifically contemporary materials in 1680 literally enacts the simultaneity of these multiple traditions and interrupts the possibility of any stable relation between the past and the present by allowing ongoing discoveries and debates to dislodge antiquity from its authoritative throne. No one version of the Cleopatra story can suffice to lock the queen into place, then, when even the "authorized" version of the play reveals its location in the complex and always changing network of early modern material and textual knowledge, knowledge that becomes visible in the reference to such only apparently marginal texts as Wansleben's. I have argued that in Agrippina, a very specific set of issues and texts directly related to female leadership in eastern central Europe becomes visible through a slow reading of the play and its notes. This final chapter analyzes the world of early modern gender relations from a somewhat broader perspective by following a network of allusions first into and then back out of a wider set of issues and texts as they are indicated in the "margins" of Lohenstein's Cleopatra. The initial dissolution of the play as an object of study into a series of textual locations that lie outside of its literal boundaries, but which are mediated by specific references in the notes, is deliberate; by first disassembling and then recollecting its many facets back into an integral image of the intersection of "race" and gender in the early modern world, we can begin to catch a glimpse of that world in textual form.

The focus in this chapter on "race" is impelled both by moments in Lohenstein's play like the Caesarion scene and by late-twentieth-century critical interest in a topic that for far too long either went unexamined or was reduced to racist stereotyping by scholars whose logic about Lohenstein is best captured in Klaus Günther Just's depiction of the African Egyptian queen as no more than a "Gefäß erotischer Energien" (vessel of erotic energies) from an otherwise unspecified "exotischer Reich" (exotic kingdom). ${ }^{5}$ The obsessive concern of the play with questions of "race" in the form not only of color, but in terms of lines of inheritance, political lineages, and strategic alliances will be the object of investi- 
gation in the next two sections. Because, however, there has been much debate recently about what it might mean to study race in the early modern period and because Lohenstein's play opens a window onto a world heavily though perhaps somewhat differently "racialized" than others visible to date, it is important to indicate at the outset how the term will figure here, particularly as it touches on the strikingly innovative profiles of the "dark" and anti-Roman characters of this play.

Although the term "race" seems to have become infinitely "malleable" in recent critical approaches to texts of this time, Kim Hall and Margo Hendricks, among others, have used it with a much welcomed specificity in their work, arguing that in this period "race" was a matter less of "complexion than of status," and specifically of status as indicative of the important political, confessional, and ideological parameters of early modern dynastic and national identity. ${ }^{6}$ In precisely this respect, Caesarion's lineage and capacity to become allied with Candace, indeed to be African as well as Roman in Lohenstein's play, could be said to make fixing his "racial" status a central task for the text, for he can conceivably challenge Augustus from a genealogically hybrid, yet also multiply legitimate position. Yet Lohenstein's play does everything but invest Caesarion with a single identity. Rather, the boy's claim to be descended from and thus of the race, or house or line, of Caesar, on the one hand, is allowed to define a political potential that makes his survival beyond Cleopatra's impending death particularly dangerous to Augustus. His access to "Ethiopian" support and allies, on the other, is based in Lohenstein's play on what his mother conceives of as her (and thus also Caesarion's) authority and power as members of the race, or line or clan, of Ptolemy and thus the legitimacy of their resistance to the covetous designs of Rome. When Caesarion is deliberately "darkened," both literally and figuratively, in the play in act 4, both of these "racial" identities become visible, since his attempt to "pass" as a dark, "African" Moor calls attention to his presumably "fair," Roman complexion. Here, race - membership in a clan, nation, or otherwise defined confessional, political, or cultural group - may be marked by tropes of color as well as by other signifying tokens or symbols. But these tropes are best read as belonging to a wide range of both subtle and overt political registers. Wansleben's travelogue on Egypt, the text Lohenstein cites as a source in connection with his elaboration of Caesarion's role in the play, may be best understood as located at the intersection of these multiple registers.

Johann Michael Wansleben's Nouvelle Relation was published in Paris in 1677 and relates the German Wansleben's travels in Egypt in 1672 and 1673. The actual "relation" of his journey only begins, however, after some one hundred preliminary pages that contain descriptions of the 
country's inhabitants, of the Nile and its flooding patterns, and of the flora and fauna of northern Africa, as well as of archaeological wonders such as the pyramids and the Sphinx. Wansleben's three-page "Portrait des Egyptians" appears in this section and is of particular interest in light of the role of his text as a source for the innovation that Lohenstein's Caesarion scene represents. ${ }^{7}$

While Wansleben fails to target color as a distinguishing feature of the Egyptians, he does discuss other group or "ethnic" traits. He is disparaging, for example, when he reports the pride of the "natives" he met, particularly among one segment of the population, the one he identifies as the most ancient. Earlier, he had written: "L'Egypte est habitée aujourd'huy par des Coptes, par des Mores, par des Arabes, par des Turcs, par des Grecs, par des Juifs, \& par des Francs. . . . Les Copts ou Coptes, sont les naturels \& originaires du Pays" (Egypt is inhabited today by Copts, Moors, Arabs, Turks, Greeks, Jews, and Europeans.... The Copts are the indigenous people) (13). And, he goes on to explain, the Copts are particularly "superbes \& glorieux" (proud and vainglorious). This pride becomes them the least as a nation or race, however, because precisely these Christian Egyptians, with their ancestral links to the Abyssinians of Ethiopia, were once a spectacularly noble and learned people. The link between Egypt and Ethiopia that was conventional at the time becomes visible here. Wansleben's text reads:

Ils sont superbes \& glorieux, qui sont les vices dont les Coptes sont particulierement atteints: \& quoy qu'ils sçachent fort bien qu'ils ont entierement perdu leur Noblesse, leur Pays, les Sciences, l'Exercice des armes, avec leur propre Langue, leurs principaux Livres \& Histoires publiques, \& que d'une Nation illustre \& vaillante qu'ils estoient autrefois, ils soient devenus esclaves, \& un Peuple vil \& odieux: Neanmoins leur orgeuil va iusqu'à croire qu'ils n'ont pas besoin dequoy que ce soit: Ils s'offencent méme quand nous autres Francs les exhortons d'envoyer leurs enfans en nostre Pays, pour apprendre les Sciences, \& pour voir comme nous nous y gouvernons.

(They are proud and vainglorious. The Copts in particular are affected by these vices, even though they are well aware of the fact that they have entirely lost their nobility, their country, their science/ knowledge, their military skill, as well as their own language, their main books and public record of history. Having once been an illustrious and brave nation, they have now deteriorated into slavehood, and have become a vile and hateful people. In spite of this, they are so proud as to think that they have no need of anything. They even 
take offense, when we Europeans encourage them to send their children to our country to acquire knowledge and to see how we govern ourselves.)

Wansleben of course fails to entertain the possibility in this passage that the Copts' refusal to allow their young to be "exported" north out of Egypt by the Europeans might be a legitimate gesture of cultural selfdefense. In his haste to construct a narrative of disintegration about Coptic culture in particular, he overlooks - or suppresses - the possibility that they might have had good reason to want to protect their racial identity and heritage.

Indeed, what is odd about what we might identify today as Wansleben's "Eurocentrism," particularly insofar as the grandeur of the Coptic tradition is concerned, is that this particular German traveler, writing here in French, was in fact very well acquainted not only with the Copts' intellectual and military achievements in days gone by, but also with contemporary developments in the land associated with their origin, namely Ethiopia. Because of these developments, the Copts and particularly those in Egypt might well have thought themselves superior to the Europeans. Wansleben's trip to Egypt in 1672-73 was not his first; a German-language manuscript attributed to him and dated 1671 describes Egypt as he visited it some ten years earlier: Joh. Mich. Wansleben Beschreibung des Egypten Landes nach dem Zustand des Jahres 1664. Von einem reysenden Teutschen in Teutscher sprach beschrieben (Johann Michael Wansleben's description of the country of Egypt as it existed in 1664. Written by a traveling German in the German tongue). This earlier text may well have been written after a trip on which the young scholar embarked at the behest of Duke Ernest of Saxony-Gotha to try and ascertain the whereabouts of one Abba Gregory, an Ethiopian bishop whose time in Egypt, Italy, and subsequently Germany had been sponsored by the duke between approximately 1649 and $1658 .{ }^{8}$ Wansleben's original charge was to journey to Ethiopia to find Gregory. He seems to have stopped in Egypt for unknown reasons, perhaps because he had heard that Gregory had drowned in a shipwreck, perhaps because he was discouraged from proceeding to Ethiopia by the patriarch of Alexandria. ${ }^{9}$ Abba Gregory was an important figure for several reasons in signaling the complexity of African-European "race relations" at this time. Wansleben's later account is interesting precisely because it reveals what its author clearly knew about the Copts, but fails to say here in his tirade.

Wansleben was the student and colleague of the great German scholar Hiob Ludolf (1624-1704), who was the early modern father and founder of Ethiopian studies. The wider world of early modern "race stud- 


\section{Cleopatra}

ies" contemporary to Lohenstein's Cleopatra begins to become visible in Wansleben's connections to him. Hiob Ludolf's interest in matters Ethiopian was driven by his commitment to an ecumenical project to unite all Christian churches. Ethiopian Christianity was centuries old; many contemporary scholars thought it provided a crucial link in an effort to unify all religions based on their common origins, an intensely important effort to an early modern European political community torn apart for more than a century and a half by conflicts associated with religious strife. ${ }^{10}$ Efforts to reunite a divided Christendom would be possible, according to the great Dutch lawyer, Hugo Grotius, for example, by developing a doctrine based on the "consensus trium saeculorum," the agreement of the "first three centuries" of Christianity, during the time of the legendary baptism of an Ethiopian eunuch by Philip the Evangelist (Acts 2). ${ }^{11}$ Ludolf was familiar with this larger complex of associations with Ethiopia common throughout the seventeenth century. Like Grotius, he was convinced that in the Ethiopian (Monophysite) Church and culture, fragmentary forms of a primitive but still pure Christianity survived, just as surely as the Ethiopian language functioned, in early modern linguistic theory, as a kind of shrine to the oldest language of mankind, the Adamic tongue. ${ }^{12}$ Ludolf's interest in the foundations of a universal religion was clearly intensified through his lengthy acquaintance with the Ethiopian Gregory, whom he had originally met as a political refugee in Rome. ${ }^{13}$ The circumstances of Gregory's arrival in Rome are important and will be the subject of investigation later in this chapter.

Ludolf taught Gregory Latin and German, and in the process became even more proficient in Amharic and Ge'ez. Wansleben seems to have collaborated with his teacher in the preparation of the two major contributions to early modern African studies that Ludolf must have begun soon after meeting the learned Ethiopian bishop, namely an Ethiopian grammar book (Grammatica Aethiopica, 1661) and an Ethiopian-Latin dictionary (Lexicon Aethiopico-Latinum, 1661). Ludolf also wrote an immense Historia Aethiopica (History of Ethiopia) (1681), followed some ten years later by his just as lengthy and detailed Ad Suam Historiam Aethiopicam ... Commentarius (Commentary on the history of Ethiopia by the same author) (1691), in which he carefully describes his initial encounter with Gregory and the bishop's place in the political and institutional upheavals in Ethiopia in the first half of the seventeenth century. Abba Gregory's presence in Europe represents an interesting moment of direct confrontation between Europe and its allegedly "prideful" or "degenerate" African "Other" in the "racializing" texts of Ludolf, so characterized because they delineate the integrated political, confessional, 
and institutional concerns of the Ethiopian people as they struggled to define their identity in a complex and heterogeneous polyimperial world. Gregory's presence and his textual afterlife in Ludolf's early modern historioethnographical texts clarify the context of Wansleben's remarks in his Nouvelle Relation.

During interviews in Gotha in 1652, Gregory was interrogated by Ludolf about the accuracy of recent European cartographical efforts (of which he apparently thought very little) as well as about the source of the Nile, the flora and fauna of the Horn of Africa, and the appearance, history, and customs of the Abyssinian people; it is probably here that Wansleben found his information on the terrain between Alexandria and Meroë, the details of which Lohenstein reproduces in his description of the route Caesarion is to take. Just as important, however, Gregory appears to have been asked to report at length on recent political developments in his homeland. ${ }^{14}$ Subsequent volumes about Ethiopia produced by Ludolf clearly capitalize on the presence of his "native informant" to give one of the most detailed accounts of east African politics during this time that exists. The Historia Aethiopica relies in part upon the Portuguese collection of observations and documents concerning Ethiopia by Tellez, but it is also different from many such volumes in that it reports directly about "the Body of the matter from the Writings and Discourses of Gregory the Habessinian,"15 a "body" of information available in Europe in the person of the African bishop himself. Gregory's voice intervenes constantly in Ludolf's account, corroborating, disputing, emending all manner of previously transmitted information, and thus interrupting previous European renditions of Africa.

Ludolf lived until 1704, but it is Wansleben who is named as the first editor of the grammar volume, for example; there, the full title reads: Jobi Ludolfi Grammatica Aethiopica. Nunc primum edita, studio \& cura Johannis Michaelis Wanslebii (Hiob Ludolf's Ethiopian grammar. First edited with accuracy and care by Johann Michael Wansleben) (1661). He thus presumably had met Gregory and had also had access to the corrective "history of [Ethiopian] peoples" on which Ludolf worked during much of his life. Who better than Wansleben, then, to send via Egypt to the Horn of Africa on the trail of the absent Gregory, once the Ethiopian bishop left Europe for good in 1658? How odd, then, in turn, that in his subsequent description of those journeys in the Nouvelle Relation, a text that Lohenstein cites, Wansleben seems to have forgotten what he must have already known in the early 1660s, namely that the long and complex history of the Copts had led, most recently, not to their decline, but rather, in Ethiopia, to a striking victory over the Portuguese representing both church authorities in Rome and an allegedly superior Euro- 
pean power. Why resort in the 1670s to a stereotypical narrative of ignorance, recalcitrance, and failure on the part of the Coptic race in the face of so much material to the contrary directly available to him at least since midcentury?

We can only speculate as to why Wansleben wrote the kind of story he did about the Egyptian Copts in his Nouvelle Relation. More important in the present context is the distance between his Egyptians and the "original" Ethiopians of their race, about whom rich sources of information were available at the time in Ludolf's monumental Historia Aethiopica. There Ludolf gives the period's most detailed account of the spectacular achievements of Gregory's people; he frames his description not just as a kind of protoethnography but also, and more centrally, as part of a detailed political narrative about the problematic activities of various groups of Europeans in the Mediterranean basin, in the Near East, and in eastern Africa in recent times. This detail, as local in nature as it is, introduces us to the kind of highly nuanced historical accounts about African politics available in early modern Europe and allows us to augment the set of discursive tools with which we analyze race in this period. "Africans" were not only identified in terms of color or myth; rather, they were also known as important players in the politicalconfessional conflicts of the time.

Ludolf's friend and colleague, Abba Gregory, for example, had been converted from his native Ethiopian Monophysitism to Roman Catholicism by Jesuit missionaries; he had, however, advanced to the post of abbot of the monastery of Mechereca, an island in Lake Tana, before his conversion, and was thus a good informant about Monophysite ritual and doctrine. It was precisely his status as a Jesuit convert that made it necessary for Gregory to flee Ethiopia first in 1632, when the dominant political forces in Ethiopia expelled the Catholics, and then again in 1648-49 - at the end of three decades of similar religious strife in Europe-when his life was threatened by Monophysite high priests, who saw him as "apostate to the foreign faith." 16 Gregory fled via Jerusalem and Egypt to Rome, where Ludolf met and studied with him between 1649 and 1652.

Sympathetic to Gregory, Ludolf was no doubt also made aware by the Ethiopian's sojourn in Italy (and by his apparent need to find further sponsorship in the north) of the disruptions caused in eastern Africa by the "work" of the Catholic Church and its agents, whose presence there had led to years of enervating internecine struggles between Jesuit allies and Monophysite defenders of Ethiopia's autonomy. Ludolf gives a detailed account in the second half of his 1681 Historia Aethiopica of the Portuguese and then Spanish presence in Ethiopia since the early six- 
teenth century and of the ultimate expulsion of the Europeans by local political forces. ${ }^{17}$ After a thorough study during the 1660s and 1670s of these events and of the apparent designs of the Jesuits to reduce the Ethiopian monarchy to the status of puppet rulers of a client state, Ludolf may have become quite uncomfortable with the Jesuit missionary project in general. He, in fact, blames the Jesuits for the inaccessibility of information about Ethiopian Christianity so important to his unifying project, because it is, he writes, "for their [the Portuguese] sakes [that] all the other Europeans are suspected to that Nation [Ethiopia], and not permitted to have any commerce among them." ${ }^{18}$ Ludolf's relationship with Gregory and the texts that resulted were a way of circumventing the "embargo" of such an exchange of ideas, language, doctrine, and history; his student, Wansleben, thought by some to have subsequently become a Jesuit himself, must have been familiar with the bishop's tales, even if he did not share his master's ecumenical vision. Ludolf's fascination in his Historia Aethiopica with the core but now "Lost Dominion" of the Ethiopians that could still be restored by means of "Alliances [with] the Europeans" in any case represents a radically different understanding of the worth of the Abyssinian race than Wansleben's assessment in the 1670s of their degenerate status. ${ }^{19}$

Indeed, unlike the Wansleben text to which Lohenstein refers so often in his notes to Cleopatra, Ludolf's texts work to document the legitimacy of Ethiopian culture, whose language, religion, and "Monarchy ... and Royal Line are no less Ancient than any among the Europeans." ${ }^{20}$ Given the culture's venerable past and strong present, there must have been a clear reason for the Coptic "racial" self-esteem that Wansleben sensed in Egypt in 1664, if this self-esteem is understood as an awareness of an identifiable legacy of cultural (confessional and political) achievements as well as of "national" habit. The Abyssinians are distinguished, Ludolf writes, by a love of learning and a disdain of petty, material goods ("Nor do they desire those things, of whose dazzling Beauties and glittering Colours they are ignorant; I mean Gems and Jewels"). ${ }^{21}$ They are equally proud of their appearance; "as the Habessines generally excell in generosity of Mind and smartness of understanding, so do they far exceed all other Ethiopians in shape of Body and symmetrie of Lineaments." ${ }^{22}$ Ludolf's striking (and strikingly ethnocentric) remark that one member of the royal house has a "countenance [that is] affable and pleasing, with a high nose and thin lips; nothing different from the Europeans, but only in colour," seems in fact almost to argue for a shared biological heritage that the discovery of common religious origins would confirm..$^{23}$ The Abyssinians are almost white and, yet, not quite.

Ludolf compares the Ethiopians to Europeans and finds them similar 
in many respects. He takes great care, however, to note the Abyssinians' great pride in their considerable darkness, occasionally remarking on the hierarchy of color among black Africans. ${ }^{24}$ In such a hierarchy, the contrast with whiteness is extreme. "[T]he Ethiopians are pleased with their own Blacknesse, and prefer it before the White colour," Ludolf explains. In fact, they "avoid being breathed upon, or touched by" Whites, whose color must be the effect of "some disease of the Body," which might be "contagious." Indeed, Ludolf reports, "some Authors write, that the Ethiopians paint the Devil white in disdain of our complexions." Learned, distinguished by a lofty and lengthy heritage, and proudly dark, the Ethiopians were also the victors in a battle to expel Romeidentified Europeans (Jesuits, Portuguese) from their country. Ludolf's respect for Gregory and for his country and his recognition that the people of Ethiopia belonged to an ancient and distinguished dark "race" capable of successfully resisting "Roman" incursions emerges out of his lengthy description of the Ethiopian landscape, customs, and history. It is no wonder that their Egyptian relations refused to be manipulated by European assumptions of superiority. It is only puzzling that Wansleben could be so unselfconsciously dismissive of their pride in his text.

To my knowledge, no documentation has been offered of a connection between Lohenstein's increased interest in Egypt and the greater African continent in the 1660s and 1670s and his contemporary Ludolf's vast efforts to introduce Ethiopia into Europe; the sheer mass of Ludolf's learned output nevertheless suggests that he must have had a great deal of support and that many scholars may have known of his projects. Wansleben's text, however, functions as a kind of connective artery between the work of these two central European polymaths and gives us a sense of just how appropriate the term race as deployed by some midto late-twentieth-century critics may well be as an analytic and interpretive tool with which to approach these texts as well as Lohenstein's contemporaneous play. His 1680 Cleopatra adopts a more Ludolfian than Wanslebian understanding of the position of the Africans vis-à-vis Europe at the time, to be sure; it paints a picture of a proud and politically astute African queen well aware of her racial heritage and committed, like Sophonisbe, to defending it in whatever ways she can. Lohenstein's invocation of the Wansleben text may be taken, then, not as a reflection of the playwright's stance on the "Aethiopians," but, rather, as an indicator of the fact that his play belongs among the many well-informed accounts and representations of the political dimensions of Europe's interactions with its racial "Others" circulating at the time. Like both Wansleben's reports and Ludolf's tomes, Lohenstein's play diversifies the image we have of early-modern Europe's understanding of the de- 
tails of political and confessional struggles on the neighboring continent that were distinctly like - indeed, often implicated in - their own. Reading it slowly produces a more complex image of gender and race in the early modern period than those to which we have had access to date.

Many modern and postmodern theorists and scholars of race have relied on the insights of biologists and physical anthropologists in suggesting that, while often associated and indeed confused with phenotype, "race" is a "manufactured," "socially constructed," and even political phenomenon and term. The availability of multiple accounts of African affairs reveals that in the early modern period, racial identity may have also had less to do with genetics than with ideological sympathies and institutional solidarity, as well as with political and confessional disputes and affinities of all kinds. In Africa as in Europe, these issues motivated the endless jostling for positions of power and authority in which various "races," houses, dynasties, and clan and class loyalty systems engaged. Understood in this way, race appears quite useful for understanding descriptions of and allusions to Egyptian and African persons, cultures, and political events during the second half of the seventeenth century in central Europe. Such allusions force themselves upon us constantly as we read Lohenstein's "African plays."

Nevertheless, late-twentieth-century antiessentializing theories have also realized that, although "constructed," racial identities must also be "lived in" and thus mark peoples' bodies and lives. Communities, themselves never homogeneous, are often "racially coded," moreover, in terms of appearance; genetically appropriate members may thus sometimes be considered part of or excluded from a national or political community on the basis of "color." ${ }^{25}$ Like Ludolf's texts, Lohenstein's play clearly addresses the implications of skin hue for political position in the earlier period as well and links color to race via gender in interesting ways.

In both the early modern and the postmodern periods, race is a category that, more "thickly described," transcends reductively "racist" arguments based solely on phenotype. Using the term in these contexts underscores the way that political, ideological, and ethnic identities condense and coalesce into complex systems of ideological and political signification, some of which are also articulated in and by a semiotics of color. In the case of Lohenstein's Cleopatra, this more densely defined understanding of race helps explain scenes like the one of Caesarion's flight, scenes that function as indicators of the major innovations in the tradition of representations of the Egyptian queen undertaken by the German play. When compared with other versions of the Cleopatra story, Lohenstein's text reveals a significant number of dislocations, or 
"ungrammaticalities," in its descriptive language as well as in character and plot. ${ }^{26}$ Like the Caesarion interlude, these interruptions in convention provide access to a network of texts in which we can observe the origins of Lohenstein's rendering of the complex racial politics of the early modern period.

\section{"No Servile Moor"?: Race and Gender in Cleopatra}

The conceit of Caesarion's Moorish disguise and plans to escape in act 4 of Lohenstein's Cleopatra is anomalous in the tradition of early modern Cleopatra plays. ${ }^{27}$ The scene calls attention to race and gender as unavoidable issues to be addressed in considering the complex political and ideological work that the characters of the queen and her son do in the play. Cleopatra begins, for example, by declaring that she sees in Caesarion not only her personal avenger but also the future leader of both Egypt and all "[d]er edlen Mohren" (the noble Moors). It will be his task to occupy the space of a specifically political "Other," to drive the Romans out of Africa and the greater Mediterranean basin - indeed, to harrow Augustus unto the very gates of Rome $(115,11.335-38) .{ }^{28}$ To this end, Lohenstein's Cleopatra provides her son with the necessary "Moorish" apparel ("dis Mohren-Kleid") and even a wig ("dis falsche Haar") to disguise himself and thus make good his escape. In a deliberate appeal to the visual markings of "Otherness" that underscore his political opposition to Rome, Cleopatra recommends that Caesarion darken his skin in order to flee: "Und diese Salbe muß dir Händ und Antlitz färben" (This oil/ointment must stain/dye your hands and face) (11. 340-41). Barthelemy has shown that the term "Moor" referred to many groups of non-Europeans in the early modern period, including "non-black Muslims." ${ }^{29}$ But the references to a "darkening" dye and to "Moorish" hair in this scene in Lohenstein's play delimit the field of definitions operating here by giving the term the very focused task of conveying color as a marker of racial origin. Yet this origin is one that clearly invests Caesarion as the symbolic African with a visible, oppositional political identity.

The race of Lohenstein's Caesarion is discursively overdetermined in this scene in terms of its gender coding as well. Its initial logic depends, for example, on the patriarchally inflected protodevelopmental biology of the early modern period, in which women were imagined more or less as the mere receptacles of determining male seed..$^{30}$ Caesarion's "original" phenotype must be understood here as derived from his father, Julius Caesar, then, as Caucasian or European, rather than from his al- 
ready "dark" Egyptian mother; the greater capacity of the male seed to fashion identity is the only way to explain the need for the blackface disguise and the wig. ${ }^{31}$ But the discontents in a logic that would reduce race to genetics and color soon become visible. Caesarion's initial concern that the Romans are overrunning Alexandria and toppling "die Marmol-Seuln der Ptolomeer" (the marble columns of the Ptolemies) (1. 315) reveals his awareness that it is precisely because he is of the Roman race (namely, Julius Caesar's offspring), but located in and identified with the powerful realm of the house of Ptolemy, that he is being sought. The question of color is thus deliberately linked to the political categories that dominate the play. Moreover, "kein knechtisch Mohr" (no servile Moor) (1. 343), Caesarion initially recoils from his mother's suggestions for masquerade, claiming that, should he be captured, he would prefer a noble death, not one dressed as an "inferior." Cleopatra explains - perhaps also to her audience - that her son mistakes the racial code suggested by the disguise. The disdained color should rather be read as a marker of military prowess and of a claim to legitimacy; numerous distinguished warriors, she elaborates, specifically the legendary Hannibal, as well as his own father, Julius Caesar, had resorted to disguises in times of need (11. 343-48).

Caesarion is persuaded by her argument and ultimately complies. Although he leaves the stage as a Moor, in an artificially "darkened" form that figures the hybrid identity that Cleopatra's references to Hannibal and Caesar invoke, he is nevertheless clearly associated with the opposition here. As we know from Dio Cassius and Plutarch, Caesarion is ultimately apprehended and murdered as a potential rival. ${ }^{32}$ The German play refers to the failure of Caesarion's escape attempt at the end of act $5(145,11.610-21)$. By investing him with a political profile associated with a possible anti-Roman alliance with Candace, Lohenstein indicates that race is not just skin-deep in his play even when it is associated with color.

The racial politics of the disguise scene in Cleopatra calls attention to central elements of this play that scholars have left unexamined. Originally published in 1661 as the first of Lohenstein's series of plays dealing with Roman subjects, Cleopatra was produced in late February and March of that year, first in the house of the patrician Keltsch family, and then in the more lofty company of the duke of Brieg. Although the 1680 version of the play into which the Caesarion scene is introduced was no longer produced, its origins in this context and in the tradition of the Schuldrama would surely have recalled the mechanics of masquerade necessary for Lohenstein's other plays. Initially the gender transgression necessary for its production would challenge any assumption of an 
unambiguous reinscription of dynastic imperial ideology in the final triumph of the "house of Caesar" over Cleopatra and Caesarion, as well as over Antonius, in the Cleopatra story as it is conventionally told; again, the distance between Lohenstein's play and earlier versions is captured by the presence of the adolescent schoolboy actor's body behind the garb of one of the play's main roles - namely, that of the politically savvy and, in at least two scenes, erotically active Egyptian queen. But it is this supplementary scene, with a darkened Caesarion complying with his "mother"'s plans for a future of resistance to Rome, that intensifies the way in which the play in its later, revised version exploits this ideological distance between ancient and early modern imperial logic by both resurrecting alternative accounts and inventing new details about the story of Cleopatra's final days. The differential politics of the German play begins to emerge in its manipulation of the sources in terms of both gender and race.

Lohenstein's version of Cleopatra's political identity is based in part, for example, on the third-century historian Dio Cassius, whose representation of Roman political developments prior to the establishment of the Principate did not strive to idealize or unambiguously glorify $\mathrm{Au}-$ gustus. ${ }^{33}$ In Dio's version, Cleopatra actually cooperates with a pragmatic and less than noble Caesar both militarily (51.9.5-6) and by plotting to do away with Antonius (51.10.5-7), yet does so in the interest of preserving both her power and her state. According to Dio, she succeeds in her deception, and her lover kills himself in direct response to her plot. Cleopatra then goes on to deploy the same strategies of manipulative eroticism, this time unsuccessfully, in the hope of eluding Caesar's grasp, attempting to match the young leader's duplicity and ruthless approach to gaining power with a political cunning of her own (51.11-13). Following Dio, Lohenstein profiles a queen who, an equal match for her Roman counterpart, uses her sex to attempt to secure victory for her race. ${ }^{34}$

This representation of Cleopatra's character and motivation distinguishes Lohenstein's play from most postclassical literary images of the queen as either seductive temptress (Dante, Boccaccio) or faithful lover (Chaucer). It also forces certain plot innovations, like the Caesarion episode, in the German text. The German Cleopatra also finds a letter from Augustus to Antonius, in which the emperor offers to pardon Antonius on the condition that he kill his Egyptian lover (130-31, 11. 147-53). It is partially this discovery that drives her to betray Antonius first; Cleopatra's action is thus to be understood politically as a kind of preemptive strike. No such letter is mentioned in the classical sources, however; its invention here works both to tarnish the image of a noble and fair- 
dealing Caesar and to develop an argument for the legitimacy of the queen's equally duplicitous response. Finally, Lohenstein invents an emissary to Alexandria from Egypt's Spanish allies, who declares his loyalty to her cause and pledges to provide military assistance and aid $(40-41,11.579-631)$ in the struggle against Rome. ${ }^{35}$ In general, these innovations place a disproportionate emphasis in Lohenstein's play on Egypt's integration into a more or less collective and organized oppositional front that Cleopatra leads.

These refigurations of plot development indicate that Lohenstein's vision of the Cleopatra story was one concerned with the geopolitics of the greater Mediterranean and Europe, in which a united resistance faced off against Rome - rather than as a love story involving the fated pair's romanticized or exoticized escape from a rationalistic, proto-imperial power with which we are familiar via various readings of Shakespeare, for example. The historical record is, of course, allowed to stand, and a triumphant Augustus is ultimately depicted. But by embellishing the Cleopatra story with allusions to the possibility and, indeed, legitimacy of political resistance, the German text carefully avoids either siding unambiguously with the Romans or calling for a reproduction of their values and acts in the here and now of the early modern Empire. Rather, in its noncompliance with an ideologically driven (and, indeed, perhaps also politically pragmatic) reproduction of imperial logic at the level of plot, Lohenstein's play mimics the onstage gap between character and actor on which its staging would have relied. ${ }^{36}$

These discontinuities bring us back to the Caesarion scene. The differential moment visible in the stage transvestism that marked the play's original production would also have characterized the racializing masquerade on which the invention of both Caesarion's disguise and Cleopatra's presumed darkness would have had to rely in the case of the later version. For just as the female roles in all of Lohenstein's plays were acted by boys, so too would any "dark" characters, such as Cleopatra in the 1661 staging (or Sophonisbe several years later), in all likelihood have had to be performed by more or less "fair" central Europeans, whose offstage preparations for their roles may have suggested the subsequent innovation of Caesarion's "darkening" disguise. The color inflection of the Cleopatra story is hinted at in some other early modern versions, such as Shakespeare's Antony and Cleopatra, I.i.6 and I.v.29, but absent in most others, such as Benserade's La Cléopâtre (1636). ${ }^{37}$ Asmuth has indicated that the Benserade play may have been an additional source, along with the Roman historians and biographers, for Lohenstein in fashioning his text. ${ }^{38}$ The difference of the German text from its French predecessor becomes particularly visible in a comparison of 
its "color" politics and its links to gender ideology, however. These differences in turn indicate where the opposing racial loyalties of the two plays lie. ${ }^{39}$

The several places where parallels between Lohenstein's Cleopatra and Benserade's La Cléopâtre seem to exist initially actually mark their very different investments in the material. The manner in which Cleopatra's inert body is characterized at the close of both texts is particularly striking. In his final speech, Benserade's Cesar, like Lohenstein's Augustus, is incensed that Cleopatre has killed herself. In so doing, she has deprived him of "un superbe ornement" (a magnificent ornament) for his triumphal entry into Rome (Benserade 51v: V.viii; Lohenstein, 141, 1l. 500-02). The characterization of her body as "ce beau corps, palle, immobile, froid" (this beautiful body, pale, lifeless, and cold) (52v: V.viii) in the French text nevertheless reveals what is ultimately most important for Benserade's Cesar, namely that it appear to his constituency that he has conquered her as object, as a "bel ornement" (beautiful ornament) (52r: V.viii). Lohenstein's Augustus likewise characterizes Cleopatra's corpse as "kalt" (cold) (1. 465) and praises her "marble" and "pearly" breasts (Marmel-Klippen ... Perlen-Brust) (ll. 523-24). His language echoes Benserade's vocabulary of immobility as well as of paleness. Although Lohenstein's Augustus ultimately demurs about the appropriateness of including a statue of Cleopatra in his triumphal return to Rome (11. 527-28), the tropes of petrification and objectification to which he has recourse accomplish rhetorically the reduction of the queen to the object of which the statue in the victory parade would have been only its literalized form. The two Romans thus seem to share a commitment to displaying their power to conquer the queen over her dead body.

Additional parallels in these final moments nevertheless mark the presence of significant differences between the two plays. Looking at Cleopatra's body appears to affect Lohenstein's Augustus physically; he feels a kind of "magnetic" attraction to her that signals her continuing erotic power (11. 521-22). A legacy, perhaps, of Dio Cassius's depiction of Augustus's reaction to Cleopatra's pleas to him just before she decides to take her life (see Dio 51.12.5), Lohenstein's characterization of Augustus as attracted to the dead Cleopatra echoes Benserade's Cesar's reaction to the sight of her beautiful corpse: "Je n'ose voir ses yeux de tenebres couverts, / Ils peuvent plus fermez, qu'ils ne firent ouverts" (I do not dare look into eyes, closed in the shadow of death; they are more powerful when closed than they ever were when they were open [and she was alive]) (52v: V.viii). Yet it is precisely her eyes and their relationship to the characterization of the queen in the French play that dis- 
tinguish Benserade's Cleopatre from Lohenstein's by pointing out her "true" racial identity.

Even though Cleopatre's control of Antoine is associated no fewer than twelve times in the course of the play specifically with the power of her eyes, the French text by no means characterizes her primarily as either a seductive vamp or its equivalent, an erotic schemer. Rather, as a character in a "tragédie galante" (as opposed to a "tragédie politique"), ${ }^{40}$ Benserade's Cleopatre's gender profile is determined by the genre, or family, class, and "race" of texts in which she finds herself. Her love for Antoine, for example, is the distinguishing feature of her character in the French play. She fears his defeat more than the defeat of her "state" (mes Etats) (8r: I.iii) and subsequently identifies herself and, indeed, is characterized by the play as a loyal wife ("j'estois femme d'Antoine") (27r: III.vi) rather than as a queen. Although Cleopatre's feigned death does cause her lover to commit suicide, as it does in Lohenstein's play, she confesses her mistake to him ("Et par ma feinte mort ie t'en cause une vraye" [And my dissembled death has brought you to a real one] (24v: III.v) in the French version, and seems to genuinely castigate herself for causing his death. Her physical beauty begins to fade soon thereafter, linked, as it is in this play, to her fidelity to Antoine; her remorse for having even attempted to sway Cesar by means of, again, her "yeux" (eyes) (47v: V.v), is all the greater since it appears to have signaled a betrayal of Antoine. In the end, then, the distinguishing characteristic of Benserade's Cleopatre is neither physical beauty nor eroticism, but, rather, "constance" both as a character and as a characteristic of a very specific genre of text.

And indeed, it is precisely Cleopatre's "constance" that ultimately succeeds in moving Benserade's Cesar, and for good reason, because it reveals that her racial identity is ultimately as Roman as his. Her claims, for example, that she must kill herself to signal her loyalty to Antoine and to defend her honor (48: V.v) are manifestly indebted to the legend of Lucretia. Her actions even cause one of her attendants to recall Portia at one point $(43 \mathrm{v}$ : V.ii). These references to Roman models of feminine virtue only underscore the ways in which this Cleopatre actually represents little or no threat to Rome. Rather, she deplores early on the way in which political motives have been attributed to her (17v: II.iii) and tells Cesar that her relationship with Antoine was purely a love affair (37v-38r: IV; see also 46v: V.iv) rather than a strategic alliance. Thus, when she goes to her death as "une âme genereuse" (a generous soul) (46v: V.iv), the French Cleopatre's actions demonstrate just as effectively as her words that she belongs to the same lineage as Cinthio's, Garnier's, and Mairet's faithful Cleopatras. ${ }^{41}$ Her deathly "paleness" in the final 
lines of the French play thus participates in a dense network of signification associating beauty and fairness with fidelity and virtue-Roman qualities all, particularly when associated with women..$^{42}$

Lohenstein's Cleopatra, on the other hand, is also undeniably beautiful, yet anything but faithful to her lover. Exactly the opposite of Benserade's queen in terms of her investment in politics, moreover, she is deliberately not "fair" in spite of what is described as her marmoreal appearance at the end of the German play. Her dark "body natural" is of interest not as a signifier of wanton exoticism, however, but rather as an inversion of the "gallant" model-as a "body politic," in other words. The German queen's erotic encounters with both Antonius and Augustus are embedded in a complex political and economic system that deliberately skirts the generically and racially homogeneous world of gallant romance constructed by Benserade. ${ }^{43}$ This heterogeneous narrative of a politicized and oppositionally "dark" Egyptian queen with ties to Africa is suggested in the Caesarion scene and ultimately emerges as central to understanding the anomaly of Lohenstein's play within the tradition of representations to which Benserade's La Cléopâtre belongs. The German Cleopatra's political identity and legitimacy are most visible in the complex ways in which tropes of color are associated precisely with her "body politic," in both its specific and in its more inclusive sense. Derived primarily from the discursive frame and rhetoric of Petrarchism, on the one hand, and from a series of contemporary texts documenting the political dimensions of a powerful African empire, on the other, these tropes are deployed in Lohenstein's text to construct a disruptive image of the Egyptian queen.

\section{The Empire Talks Back: Blazons and the Dark Body}

Lohenstein's Cleopatra relies even more heavily than Benserade's play on clearly marked fragments of Petrarchist discourse to image forth and hyperbolically praise the queen's beauty. The problematic use of this discourse nevertheless allows the oppositional contours of her political identity to emerge. It is not surprising that the scenes in Lohenstein's play most crowded with moments of "top-to-toe enumeration" are those in which Cleopatra either feigns death (80-89) in order to bring Antonius to despair or in fact kills herself in order to escape Augustus's designs (140-43). By this time so conventional as to call attention to its inauthenticity as a descriptive device, the "inventory of fragmented and reified parts" that constituted the genre of the blazon had the effect of reducing the subject of praise, often a woman, to an unreal, even inani- 
mate object, capturing her in a rhetoric that describes in order to control. ${ }^{44}$ This rhetoric would appear to be appropriate to scenes in which Cleopatra's body is represented as just as lifeless as the alabaster of her breasts $(81,1.24)$, the ivory of her arms, and rubies of her lips $(83,11.83-$ $84)$, or the marble reefs of her pearl breasts and coral lips (142,11.523-24) on which Antonius has been stranded. ${ }^{45}$

The adolescent actor who mimed Cleopatra was of course neither a woman nor dead in the final scene of Lohenstein's play, and the audience in Breslau did not occupy in any unproblematic fashion the space or position of a proto-imperial Rome, as we have seen. Indeed, the awkwardness of using the language of blazoning to control a woman being played by a boy seems almost deliberate and is particularly visible in the initial scene of act 3, in which Cleopatra is clearly depicted as affecting death in order to provoke Antonius's suicide. Reversing the theoretical basis of Petrarchism, which assumes the silence of the described and objectified woman, Lohenstein allows his Cleopatra to blazon herself here. ${ }^{46}$ In the process, she defies both generic logic and the relations of power on which Petrarchan convention relied. Her explanation of the ruse $(82,1.61)$ only to her "vertraute Charmium" (faithful Charmium) $(80,1.1)$ underscores the political dimension of her own engagement with the rhetoric of blazoning. Her other women attendants and slaves are to be kept in the dark, so to speak, so that they may more effectively spread the news of her death (11. 67-74). It is thus that Antonius is to hear of it. And indeed, even though she is as little dead in this scene as her breasts are of "marble ... tipped with rubies" (Marmel-Brust ... mit Rubinen [ge]spitzet) $(98,1.561)$, her lover does stab himself out of despair on learning of her "death," thus playing into the scheme the queen has designed (70-71, 11. 427-80, and 81-82, 11. 31-48) in order to secure her own as well as Egypt's safety. Ironically, Cleopatra engages in resistance to Rome's designs, designs in which Antonius is implicated, as the interpolated letter from Augustus to Antonius suggests, precisely at the moment when she begins to objectify herself. She thus frustrates expectations of a powerless, pale, or silent woman traditionally associated with the mechanism of the blazon by taking its conventions into her own hands.

The inauthenticity, yet political effectiveness of descriptive rhetoric emerges with greatest clarity when we turn to the most obviously disarticulated use of the tropes of display familiar from the Petrarchan tradition in the crucial scene between Antonius and Augustus's representative, Proculejus, in act 1 . The color coding of the blazoning tradition and then the disruption of that coding become significant here. Derived from neither the ancient sources nor from Benserade, the scene seems 
to offer Antonius the option of regaining the "Roman" identity so obviously absent earlier in the extraordinarily politicized "war council" with which the act begins, where he is already heavily identified with Egypt. There, Antonius is the "Fürst" (prince) of a "Reich" (kingdom) under assault (36, 11. 450-51) and an ally of other anti-Roman forces, among them (anachronistically and at odds with the political record) "Juba with his Moors" and "half of Africa" (Juba seine Mohren . . . halb Africa) (1l. 424-25). ${ }^{47}$ Act 1 goes on to clearly delineate Egypt's and thus Cleopatra's cultural and political profile and Antonius's implication in them. The interview with Proculejus thus represents Augustus's last, illmanaged attempt to reclaim Antonius for Rome. Instead, it only heightens Antonius's and Cleopatra's oppositional racial identity and status.

The standoff between the two fronts becomes particularly heated around the subject of Cleopatra, the wealth of Egypt, and her and Antonius's disposition of it; the scene reaches its crisis in Proculejus's declaration that the terms of the peace include Antonius's surrender of "Egyptens gantzes Reich" (Egypt's whole kingdom) $(48,1.833)$ and a return to Octavia, his Roman wife. Here the already Africa-identified Antonius stumbles, resisting the pressure to abandon both Egypt and its queen. Proculejus pursues his goal by attempting to devalue Cleopatra in Antonius's eyes. He does so by contrasting her to Octavia. "Wer hat ein Römisch Weib ie Mohren nachgesätzt?" (Who ever thought less of a Roman woman [and more] of a Moorish one?), Proculejus queries (45, 1. 757), and adds: "Was kan dem Römer an der Mohrin viel gefallen?" (What about [this] Moorish woman can please a Roman to such a great degree?) $(48,1.863)$. Antonius's identification with Egypt and Cleopatra's designation here as "Moorish" allow clear battle lines to be formed between Proculejus's Rome and its "Others," the two sides figured in the implied dichotomy between a "fair" Octavia and a "dark" Cleopatra. ${ }^{48}$

Stichomythia characterizes well over half of the dialogue between Antonius and Proculejus that follows; the formal properties of the verse mirror the geopolitical standoff being staged in their exchange. The language becomes still more condensed - even as it begins to appear problematic in its registration of color - in the competitive blazoning of the two women with which the scene ends (11. 864-69). Antonius insists in the first two feet of line 864, for example, that Cleopatra's mouth is decorated with rubies; Proculejus parries, in the second half of the line, with an equally compact rejoinder that Octavia's lips are of coral. Antonius then declares in line 865 that Cleopatra's limbs are "aus Schnee" (of snow), to which Proculejus replies, again, in the second half of the line, that Octavia's are of ivory. Cleopatra's breasts are of alabaster, finally, according to Antonius; Octavia's are of marble, Proculejus retorts (1. 866). 
While the debate strains to create a hierarchy of beauty, the easy variability of the reifying vocabulary of course indicates the two women's interchangeability precisely as objects. Yet the proximity of tropes originating in the vocabulary of fairness (alabaster, marble, snow) to explicit references to Cleopatra's Moorishness calls attention not only to their inauthenticity but also to Antonius's almost naive use of the blazon in this context. His blind adherence to a traditional rhetoric that would render Cleopatra passive suggests how deeply - and inappropriatelyinvolved he is in a Benseradian discourse of loyalty and beauty in the midst of a Lohensteinian universe governed by Staatsräson, as Junius points out $(50,1.900)$. Antonius then goes on to attempt an equally infelicitous retreat into pastoralism $(52,1.976)$, even as Antyllus strives to warn him about Cleopatra's political (double) dealings with Augustus. The blazoning interlude thus calls attention to the very failure of descriptive rhetoric to accomplish its traditional task in the case of this Cleopatra - the task, that is, of reducing a potentially dangerous woman to silent and powerless object. The strength of her political commitment and the difference of her racial loyalties from those of the more compliant Octavia emerge as a result.

The use of the language of display highlights the degree to which Lohenstein's Cleopatra's political identity becomes visible in her disruption of conventional expectations about gender. Once we are made aware by the very use of the blazon of the discrepancy between Antonius's language and the object it purports to describe-between the tropes of fairness he deploys, for example, and an Egyptian queen who is characterized as both Moorish and dark here and elsewhere-it becomes clear that this Cleopatra is not only not fair, but that her color and her ability to control the rhetoric of blazoning herself also signify not just a difference in complexion but a strong and ultimately oppositional political profile as well. Proculejus clearly understands the "dark woman" as dangerous and renews his demonization of Cleopatra in his exchange with Archibius, her advisor, in act 2, when he (Proculejus) characterizes her as Antonius's "braunes Ehweib" (brown wife) $(73,1.531)$, who must use "Schminck und Pracht" (makeup and jewelry) (1.535) to mask the "Heßligkeit" (ugliness) (1.536) of her darkness. Cleopatra contests such a devaluation of her "failure" to fulfill the color categories of the standard Petrarchan conceit by deploying her refusal of a silent and disempowered "pale" role as part of a political agenda.

Lohenstein's Cleopatra first engages the rhetorical apparatus of (self-) objectifying description in pursuit of a political agenda in her deliberate betrayal of Antonius at the beginning of act 3. In that scene of feigned death, the queen adorns herself in preparation for her "burial" with the 
very gems so often invoked rhetorically in the blazon (85, 11. 160-64). But in both her self-adornment and in her own use of descriptive language, Cleopatra claims agency and control of that means of objectification by deploying it as part of a strategy of political manipulation. This profile receives further nuancing, particularly in terms of her color, in Cleopatra's interview with Augustus in act 4, in which she attempts in a second, extended instance of self-blazoning to seduce him into allowing her to maintain her political autonomy. If this fails, she at least seeks to avoid being transported to Rome as a captive. She calls attention to her "faded coral mouth" (unsre Mund-Corallen/Entfärbt) that will become "deep purple as a ruby" (sich bepurpern mit Rubin) when and if Augustus favors her with his love, and she recalls to him that precisely "[d]ie Bräune des Rubins sticht blasse Perlen weg" (the brownness of the ruby vanquishes the pallid pearl). His "pale" Roman wife, Livia, is of course meant here (121-22, 11. 529-68). While Augustus appears to give in at lines 569-71 to the seduction and thus to this "brown" beauty, Cleopatra's political maneuvering is, of course, ultimately unsuccessful in this second attempt. But in this scene, as at the beginning of act 3 , Cleopatra's oppositional political profile emerges out of an ability to control the techniques of blazoning, on the one hand, and her emphasis on her "darkness" as an asset in the politics of seduction, on the other.

Lohenstein's Cleopatra's manipulation of Petrarchan diction calls attention to her dark complexion and to her attempts to further her political agenda. Her various modes of self-articulation signal those elements that distinguish her in Lohenstein's play, namely her status precisely as a non-"fair" object and anti-Roman force. She takes on this identity by producing a self-objectifying descriptive rhetoric that plays with the color politics of certain literary conventions while also disrupting inherited scenarios of female passivity. As blazoned and blazoning female object at one and the same time, she is not just deliberately dark, but also and once again deliberately not silent, "talking back" in a gesture of active, political seduction. This generically disruptive act belongs, at least in this play, to a clearly visible oppositional identity that emphasizes Cleopatra's race-her identity, that is, as an "African" queen. The origins of this identity emerge in the dialogue between the main "body" of the play and Lohenstein's "updated" notes.

\section{The Politics of Textual Resistance}

If we reread the self-conscious use of the discourse of the blazon as it appears in Lohenstein's Cleopatra through the lens of a valorized dark- 
ness that also represents Cleopatra's status as a political agent, the play's heightened geopolitical rendering of what for many other early modern playwrights was merely a tragic love story begins to make sense. This German Cleopatra is neither whorish nor blindly faithful. Rather, she figures a "dark" Egypt that is a worthy political opponent to Rome. The political relationship between the two powers is gendered in Lohenstein's text as a result of its implementation via the rhetoric of the blazon. Yet gender and racial political profile work together here. Canidius, Antonius's field marshal, describes, for example, the "emperor"'s desire to tighten his "net" around both the woman and her resources, around both Cleopatra and "Egypt's treaures" ("des Keysers Netze/ Fischt nach Cleopatren/und sucht Egyptens Schätze") (24,11. 47-48) at one and the same time. In association with Augustus's legendary voluptuousness, Canidius juxtaposes Cleopatra's physical appeal with the fertility of the Nile (11. 54-57) and goes on to explain: "Weil Africa trägt Gold/Korn/ Balsam/Helffenbein/Wil er der Mohren Haupt/Egyptens Zinßherr seyn" (Africa produces gold, grain, balsam, and ivory. For this reason he desires to be the leader of the Moors and the Landlord of Egypt) (25, 11. 61-62); the formulation underscores the consistent conflation of the woman, Cleopatra, and Egypt with a feminized African continent in Lohenstein's play. The African products echo the vocabulary of the blazon with striking precision here.

Proculejus goes on, moreover, to explain in his interview with Antonius that Egypt is even more fertile than Asia $(48,1.845)$, characterizing it as the "Korn-Haus" (granary) of the east and the west (1. 847). Historically Rome did become dependent on Egyptian corn, and most of the colonizing efforts in greater Africa in the first century C.E. were initially designed to secure provincial alternatives to or the expansion of Egyptian grain-producing capacity. ${ }^{49}$ But Proculejus's description of the land's fecundity comes quite strategically just before the blazoning contest between himself and Antonius analyzed earlier, a contest in which Cleopatra herself becomes an object in a rhetorical and political "traffic in women." Augustus's envoy, Thyrsus, is thus probably quite correct to quote his master: "Des Keysers Sprichwort ist: Egyptens Kräuter/ Aehren/Gewässer/Weißheit/Luft/Gesäm und Frauen wären/ / Die besten in der Welt" (The emperor always says: Egypt's herbs, wheat, rivers, wisdom, air, seed, and women are the best in the world) (58, 11. 40-43). Like the jewelry, vehicles, architectural monuments, mounds of grain and even hippopotami that Augustus confiscates as booty and has shipped to Rome (147, 11. 673-95) at the end of Lohenstein's play, Cleopatra's displayed body was to have represented his conquering of a rich, exotic, and dark land. Her suicide forces him to resort to a golden 
image of the Egyptian queen in his triumphal parade $(142,1.508)$ in its stead; but the statue only reminds us of the status as conquered political opponent and commodity that she, as the "Königin der Mohren" (queen of the Moors) $(109,1.125)$, was to have had. Conversely, the feminized and sexualized continent of Africa, with Alexandria as its capital (1.116), was to be subjected to the needs of Rome and of an emperor from whom no woman was safe $(25,1.54)$.

The association in Lohenstein's play of a darkened and politicized Cleopatra not only with Egypt, but with Africa as a whole is represented, then, as a powerful threat to the Romans. Yet her political profile also functions as a source of political strength to the Egyptians and Moors. This more balanced, "off-center" view of Rome's "Other" as an equal opponent distinguishes Lohenstein's play from other versions of Cleopatra's story that either feminize her to the point of political inefficacy or inscribe her and Egypt in a narrative that subjects them to a necessarily triumphant Rome. The play works hard, for example, to associate the queen with a political influence in the sub-Sahara beyond her immediate kingdom. Archibius claims that if Augustus can conquer her, "Gantz Africa wird ihn ohn allen Zwang anbethen" (all of Africa will adore him without force) $(109,1.141)$, suggesting that as Egypt goes, so goes the continent. Perhaps based on a suggestion in Plutarch that "from Africk ... all from the province of Cyrenia, unto Aethiopia, was subject unto Antonius," ${ }^{50}$ moreover, Lohenstein's Antonius may despair at the news that his allies, consisting of "all of Africa," are "lost" (gantz Africa ... [ist] hin) to Augustus's ships (26, 1. 113), but soon thereafter claims that "[e]s hab halb Africa den Harnisch angelegt" (half of those in Africa have pulled on their armor) $(35,1.425)$ to ally themselves with his anti-Roman cause. In both cases, he is characterized as the head of a pan-African resistance.

In one of her last speeches, Cleopatra herself goes to quite some length to legitimate the aura of African power associated with both Antonius and herself, a power so clearly perceived as a threat by Rome, by claiming that her sphere of influence and, indeed, the dominion of the Ptolemies had reached from the Pillars of Hercules in the west to the Tanais River in the east, and as far as the southern tip of Africa and beyond (130, 11. 116-22). As the representative of this dynasty and as the incumbent ruler of a vast kingdom, she will not allow herself to be humiliated in a Roman triumphal march (129, 11. 106-10). Lohenstein's play had cast Cleopatra's seduction of Antonius in the name of protecting herself, "unser Haus/Und Ptolomaeus Stul" (our house and Ptolemy's throne) (71, 11. 468-69). The key to her clear identification with the great dynasty and thus the origins of her racial identity here lie in the text of her final speech. 
The dynastic claims with which Lohenstein's Cleopatra defines her Ptolemaic lineage in act 5 of the play are textually striking because of their geographical specificity, but also because of the almost formulaic way in which she articulates them. Her sphere of influence extends over vast distances and equally far in all directions, Cleopatra recites; she names specific natural landmarks (rivers, oceans, the Pillars of Hercules) down to "wo die Meeres-Wellen/Die Sudspitz Afrikens stets rasend

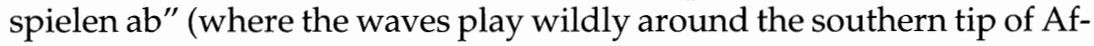
rica) (130, 11. 120-21). The stilted style of her description of the extent of Egyptian power and its coextensiveness with a vast empire and sphere of influence in parts south calls attention to the seven-line catalog of place names as an interruption in the passionate dramatic dialogue that otherwise characterizes these last scenes. The reserve she displays in her inventory of territories is as foreign to the context of her imminent suicide as Lohenstein presents it as are the origins of her speech in a generic context that would seem equally distant from this classicizing play. For when Cleopatra cites as the source of her knowledge about the geographical extent of her realm "[d]ie Marmel zu Adul" (the marbles of Adul) (130, 1. 117), which "speak" (sind Zungen) (l. 118) the borders of her vast kingdom, she reveals that both she and Lohenstein are in fact quoting a specific source here, namely inscriptions found in the city of Adulis, located on the Red Sea. According to the playwright's elaborate gloss on this speech in the notes (192-94), the inscriptions at Adulis were made at the time of Ptolemy III. Taken in the seventeenth century as a matter of historical record-as sources, that is, for our knowledge of the extent of Ptolemaic influence and power-the inscriptions provide an extraordinarily detailed political and military map of Egyptian influence in the third century в.C.E. ${ }^{51}$ Lohenstein reproduces a large part of the inscriptions in his note in the original Greek; the textual origins of his Cleopatra's sense of the great geographical range of her power may be found here.

Lohenstein's lengthy gloss on the inscriptions at Adulis contains a list of the tribes subjugated by Ptolemy in his moves south and east (193, 11. 96-101, and 109-12, 114-17) as well as an enumeration of the physical landscapes of immense, freezing mountains and burning hot expanses that he and his troops traversed as they conquered (11. 113-14) and of the prisoners they took (11. 121-22). The contours of Ptolemy's vast kingdom emerge out of this succession of lists. Even if Lohenstein was a man "of little Greek," it is not difficult to trace the origins of Cleopatra's speech to these details, or to realize that Lohenstein must have wanted his source for them known. The dimensions of Egypt's "African" connections emerge in this text. In the note, Lohenstein cites "Ptolemy,"

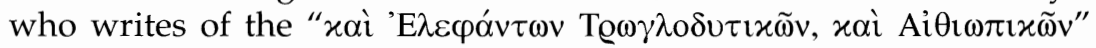




\section{Cleopatra}

(Troglodytian and Ethiopian elephants) $(193,1.94)$, for example, which

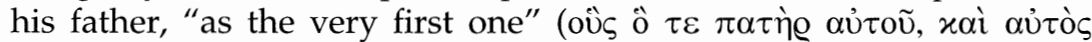
$\pi \varrho \tilde{\omega} \tau \circ \varsigma)$ brought into Egypt (11. 95-96). The subject of the Ethiopians whom he had conquered (194, 11. 135-36) and over whose land he ruled is central as well. Given the popular association of Africa in general with elephants and strange peoples, such as the Troglodytes, in the early modern period, on the one hand, and the popular use in Latin of the originally Greek term, aethiops, as a virtual translation for Moor, on the other, this "ancient Egyptian" inscription functioned quite handily as a source for Lohenstein's association of his Cleopatra with a dynasty that controlled large areas of a "dark" greater Africa, including territories that were known as Abyssinian Ethiopia in Lohenstein's time. His reference to the inscriptions in his notes helps explain the several places in Lohenstein's play where Egyptians and African Moors form a political front. The darkening of the German Cleopatra thus simply registers what was probably considered a matter of historical and political fact at the time, and opposes the Ptolemaic queen of an immense EgyptianAfrican empire to an allegedly "fair" (proto-) imperial Rome..$^{52}$

Lohenstein's note on the inscriptions at Adulis resituates the play in a network of texts like Ludolf's and Wansleben's that, fascinated with Europe's "Others," document their existence in elaborate detail. His Cleopatra cites inscriptions found, according to the playwright's note, "hinter einem Marmernen Stule in einem zugespitzten Stein" (in a pointed rock behind a marble throne) $(192,11.82-83)$ in the "Moorish" coastal city of Adul (in Mohrenland) (1. 81). The inscriptions reproduced in the note were known to the seventeenth-century playwright in a somewhat different form than we have them today, however, in what he describes as a collection of accounts of "merckwürdigen Reysen" (marvelous voyages) published in Paris in 1666. This is a very contemporary source, indeed, new enough not to have been in the notes to the 1661 Cleopatra. The novelty of the 1680 note on the inscriptions calls attention to the innovation that Lohenstein's play represents.

In the note, Lohenstein names as the transcriber of the Adulian inscriptions the "monk" Cosmas $(192,1.83)$. Cosmas, also known as Indicopleustes, was an Egyptian man of faith in the fourth century; how his transcriptions came into the hands of a Parisian publisher in the late seventeenth century is unclear. Klaus Günther Just concurs, in his 1955 bibliographical "Register" of Lohenstein's sources, with the 1666 date of the Paris collection's publication given by the playwright, but characterizes this edition as a "Neudruck" (reissue) because a somewhat earlier-indeed, presumably the first-edition of the Relations de divers voyages Curieux (Accounts of several remarkable journeys) was printed 
in Paris in 1663. In this earlier edition, the Cosmas text appears as the second half of a volume that contains as its first half a Description des Pyramides D'Egypte (Description of the pyramids of Egypt) by one Jean Greaves (1602-52), professor of astronomy at the University of Oort and also, according to Hughes-Hallett, an Oxford don. ${ }^{53}$ In spite of his numerous references to textual sources on Egyptian lore, the distinguished mathematician and orientialist Greaves maintains numerous times in the Description that he actually traveled to Egypt in 1638-39 and is only describing what he himself observed. ${ }^{54}$ The second half of his text in fact includes numerous illustrations, diagrams, and measurements of artifacts that he claims to have discovered in the tombs of the Ptolemies, data that would seem to support his claim of having actually been an eyewitness to the treasures of the ancient world as they were still available in Lohenstein's time. The documentary aspect of Greaves's account explains why his text was bound together with the Cosmas text, itself also a kind of inventory of material remnants of a Ptolemaic past. The 1666 edition of the Relations de divers voyages was probably much like the one published in 1663. Not surprisingly, Lohenstein also cites Greaves in the notes to Cleopatra on numerous details $(191,11.1-13$, and 206, 1. 646).

The juxtaposition of the two texts both in the 1663 volume printed in Paris and in Lohenstein's annotations to his play may seem odd at first sight. The Cosmas text must have already been well known by the time it was published; the Greaves text, however, was apparently based on relatively recent empirical observation of the grandeur of Ptolemaic achievements by the northern European scholar. The combination becomes somewhat less puzzling, however, when we analyze the Cosmas text that Lohenstein cites in detail. Available in the 1663 version printed in Paris with a facing French translation, of which Lohenstein cites only the Greek in his notes, the Cosmas text is punctuated throughout by claims that it is based on observation. "L'experience m'a enseigné le plupart des choses que ie viens de rapporter") (Experience has taught me about the majority of the things that I have just recounted), Cosmas writes. ${ }^{55}$ In spite of the conventionality of such appeals to empiricism in travel accounts both old and new, we have no direct cause to disbelieve the words of the monk who, after all, claims only to be transcribing inscriptions, not interpreting them. The Dutch professor's text too serves in large part as a kind of container or shell for the compiling of measurements, which he claims to have taken himself. The appearance of the two documents in the same number of the Relations de divers voyages series merely marks the generic similarity of the two texts; both sought to merge learnedness with the impulse to gather concrete data available 
in the here and now, turning this almost antiquarian pursuit into the stuff of early modern chorography, topography, and natural history. ${ }^{56}$ Even if authored many centuries apart, Cosmas's and Greaves's texts signal the interest of mid-seventeenth-century Europe in the actual dimensions of Egypt's ancient glory.

Lohenstein's reference to what was probably a 1666 reissuing of the popular Relations de divers voyages is significant because it testifies to the ongoing fascination certainly in France, but clearly in the eastern reaches of central Europe as well, with voyages of discovery not just to the so-called New World but also to the ancient as well as contemporary civilizations of greater Africa. Critics have noted that Lohenstein seems to have relied heavily on the work of the great Jesuit scholar Athanasius Kircher for his references to Egyptian culture; the many citations in the notes to Cleopatra to works by John Selden (1584-1654) and Samuel Bochart (1599-1667) indicate a similarly learned direction to the playwright's research. ${ }^{57}$ The Cosmas citation is somewhat different, however, particularly insofar as its publication along with the Greaves text indicates other kinds of more popular sources for Lohenstein, sources even more empirically disposed than Kircher. These sources stand out most by virtue of the frequency with which Lohenstein cites them in the notes to Cleopatra and are best exemplified by the Voyage d'Italie, de Dalmatie, de Grece, et du Levant (A voyage to Italy, Dalmatia, Greece, and the Levant), published in Lyons in 1678, which is an account of one Jacob Spon's trips of 1675-76, and the Wansleben text mentioned at the opening of this chapter, the Nouvelle Relation En Forme de Iournal, d'un Voyage faiten Egyte ... En 1672. \& 1673., published in Paris in 1677.58 The Wansleben citations outnumber the references to Spon in Lohenstein's notes by more than two to one and point in the direction of additional texts, such as those by Ludolf, that deal with the specifics of contemporary Egyptian-African-European relations. Spon, however, articulates a position on the importance of empirical studies in his Voyage d'Italie that serves nicely as a theoretical legitimation of accounts such as Wansleben's and Greaves's. Spon's remarks shed light on the logic behind Lohenstein's interest in the tradition of texts to which these narratives belonged.

In a polemical comment on the distinction between history writing and the empirical objects of history, Spon writes that even if there were "un second deluge universel" (second flood) that destroyed all books, "l'histoire des siecles passez" (history of past centuries) would nevertheless persist. ${ }^{59}$ For, Spon continues, he could "par le secours des medailles, des marbres, des gravures, des bas reliefs, \& des autres monumens anciens ... composer sans le secours des livres une histoire 
Romaine assez ample, non pas peut-estre tant que celle qu'on tireroit des Livres imprimez, mais plus certaine \& plus curieuse" (with the help of coins, marble, etchings, bas reliefs, and other ancient monuments ... compose without the aid of books a quite full/adequate history of Rome, not the same, to be sure, as the one that could be derived from printed books, but a more accurate and marvelous one). Spon's faith in objects, of course, did not prevent him or others from authoring texts about the voyages and observations they made. But an interest in the "certain knowledge" provided by artifacts and empirical accounts may have been what led the Parisian publisher to reproduce the Cosmas transcriptions of the stones of Adulis in the 1663/1666 Relations de divers voyages along with Greaves's countless measurements of the Ptolemaic tombs. Lohenstein's frequent references to texts such as these, as well as his several citations of materials originally published in one of the first scientific periodicals in Europe, Le Journal des Scavans, calls attention to a steady interest--indeed, faith - in something like a New Science approach to the study of contemporary geography and politics as it was expressed in a vast network of texts pouring forth from Europe's presses at the time. ${ }^{60}$

Cleopatra's quotation of the Cosmas transcriptions thus permits us to extend the range of Lohenstein's play's reach well beyond the boundaries of the edition of the text as authorized by its author in 1680 into a print universe in which domains and cultures certainly comparable with, if not also greater than, those of Europe were objects of great fascination. Lohenstein's Cleopatra understands her racial origins as geographically and politically rooted in ancient cultures about which her author seems to have known a great deal. Lohenstein's knowledge of her racial identity in this sense is derived, then, from accounts like Cosmas's and, indeed, Wansleben's. It is for good reason, then, that she is not quite as white, indeed, not as color neutral, as her French sister in Benserade's play, in spite of the fact that she is sometimes associated with tropes of fairness. Rather, precisely in the inappropriateness of these tropes to her case, the ideological implications of which called up scenarios of passivity and disempowerment, Lohenstein's Egyptian queen finds her place alongside Wansleben's recalcitrant Copts, Ludolf's proudly dark Ethiopians, and Cosmas's and Greaves's dynastically distinguished Ptolemies - all of whom provided powerful alternatives to Rome's apparently singular political and dynastic profile in the ancient and early modern worlds. The key to understanding the German Cleopatra's racial identity may lie, then, in the literal margins of the play, in Lohenstein's references to texts like Wansleben's, with which his depiction is clearly at variance, on the one hand, and like Ludolf's and Cos- 


\section{Cleopatra}

mas's, on the other, all of which explain the extent of the difference between his play and Benserade's.

Lohenstein's strong and savvy queen, almost evenly matched with Augustus, symbol and model of political prudence and power, certainly appears anomalous in the tradition of early modern stage Cleopatras. Yet, the schoolboy actor playing her may well have understood her disarticulated character not as a reduction to a stereotypical position, but as an expression of the possibility of a real alternative to Rome, an alternative visible in the enormously informed tomes about Egypt and Africa by Ludolf, Kircher, Greaves, and others circulating in Europe at the time. In the gap between his character and those that dominated the vernacular tradition in French, for example, as well as in the gap between his European, male body and the African, female role that he played, the boy actor in Breslau may also have registered the possibility of not desiring to identify with or reproduce the traditional telling of Roman political history at all. The heterodox profile of his character is matched by the complexity of its sources in the margins of Lohenstein's Cleopatra as printed text. Reading these margins deeply and slowly allows the density of the discursive systems called upon to represent race, gender, and the complexities of geopolitics in the early modern age to emerge. 


\section{Conclusion. Philology, Lohenstein, and the Post-Baroque}

In my series of readings of Lohenstein's Roman plays, I have tried to show that they both are and are not what they seem. Indeed, stabilizing their meaning is as difficult as it is because they seem to be so many things: gargantuan exercises in a baroque hybrid of scholarly excess and stage production, as well as versions of Roman history that reveal the difficulty of telling that history in the first place, on the one hand, somewhat unexpected products of the culture of the Protestant schools in Silesian Breslau in the mid- to late seventeenth century as well as polymorphic commentaries on the complex intersections of the material and ideological conditions of gender formation in early modern eastern central Europe, on the other. How we view them-what the literal conditions of the production of knowledge in and about these texts both were and are-influences what we see. I have argued that the work of philology permits us to descend into the intertextual depths of these plays and the world of their sources as a way of respecting their difficulty. Lohenstein's annotational apparatus itself calls for this work, signaling to readers that he would have them move into and around in the "marginal" world of learning, politics, and power inscribed in his texts as they considered both the productions and the print events that the plays were. Of course, this world turns out not to be so very anomalous on closer inspection but, rather, a very specific part of an early modern universe densely populated by multiple books, personalities, and events, some well known in their time, others less so, but all central for our understanding of the world of these odd Roman plays. I have argued that the texts themselves provide a way into this world; reading them slowly allows us access to a potentially destabilizing set of scenarios that give us new information about what the cultural production of the period was doing when it engaged in the representation of these powerful women of antiquity on the early modern school stage.

The late twentieth century is not the first time, however, that readers of what specialists call the Zweite Schlesische Schule (Second Silesian School) of German-language literature of the Baroque period have experienced some instability when approaching these texts. Walter Benjamin, whose famous Ursprung des deutschen Trauerspiels (Origin of the German tragic drama) (1928) may have caused the occasional postmod- 
ern literary historian and theorist to wonder about the arcane Germanlanguage plays to which its author refers, calls attention there to both his own and other scholarly reactions to Lohenstein's texts and others like them in ways that strike similar chords. As a way of beginning to ponder the broader implications of the kind of mobile knowledge projects that both Lohenstein's texts and my readings of them may suggest, I turn first to Benjamin's version of the Baroque and then to a more recent reception of Lohenstein's plays in the mid-twentieth century edition of his plays by Klaus Günther Just, in order to examine how texts like these involve us - their readers - in producing multiple "afterlives" for them in philological ways. ${ }^{1}$ Whereas Benjamin calls attention to the instability of the picture he produces, Just does not; indeed, he tries to claim that his is a stabilized and stabilizing version. Closer examination of Just's Lohenstein edition using some of the conceptual tools and theoretical positions suggested not only by Benjamin but by the plays themselves nevertheless reveals the mobility of Just's explicitly philological task. As we consider what versions of the past we produce when we construct our own critical Nachleben of the texts of the early modern period, the examples of Benjamin and Just suggest two ways of considering how such "afterlives" get constructed at different points in time.

\section{Benjamin and the Post-Baroque}

In September 1924, Walter Benjamin wrote from the island of Capri to his friend and mentor, Gershom Scholem, about his work on his postdoctoral thesis (Habilitation) on German Baroque drama; the plays of Lohenstein figure importantly in the thesis, which was of course to become the famous Trauerspiel book, first published in 1928. Benjamin had spent nearly a year and a half reading and taking notes on the "entlegnen" (remote) texts of the period, a good part of it in the Staatsbibliothek in Berlin. ${ }^{2}$ In addition to nearly six hundred citations from the original texts, all arranged and ordered, as Benjamin had written earlier to Scholem, with an "exzentrischer Akribie" (eccentric meticulousness) that belies both a research methodology that he admitted was fairly idiosyncratic and his highly selective text base, Benjamin seems also to have brought with him to Capri some of the most recent secondary literature on the subject, much of which finds its way into the footnotes of the final draft. ${ }^{3}$ Of particular interest are his comments in the letter to Scholem about the work of one Herbert Cysarz, a recent Austrian Ph.D. in Germanic languages and literatures. Benjamin writes that he had read Cysarz's book, probably his Deutsche Barockdichtung (German Baroque 
literature), which was published that same year, and found many of his ideas confirmed in it. He comments: "Es [Cysarzs Buch] ist weder in der Dokumentation noch in den einzelnen Perspektiven verfehlt und unterliegt im ganzen doch vollständig der vertiginösen Attraktion, den dieser Stoff auf den, der sich beschreibend vor ihm aufpflanzt, ausübt, so daß statt einer Erhellung des Gegenstandes nur wieder ein Stückchen Nachbarock (mit einem r!) herauskommt" ([Cysarz's book] gets the point both in documentation and in the individual readings/perspectives and [yet], succumbs entirely to the vertiginous magnetism that the material exerts on anyone who confronts it in an attempt to describe it, such that, instead of elucidating the object [of study], only a little fragment of the post-Baroque is the result). Benjamin nevertheless concludes that any weaknesses in the Austrian's study derive not from his method but, rather, from the object. He writes: "Es ist für den Stil des Barock ganz kennzeichnend, daß, wer einmal während seiner Inspektion aus dem angestrengten Denken herausfällt, sofort seiner hysterischen Nachäffung verfallen ist" (It is entirely characteristic of the Baroque that, if one is to deviate during one's study [inspection] of it from the most intense [rigorous] pattern of thought, one falls victim immediately to mimicking it in a hysterical way).

Cysarz's work on the Baroque does indeed display somewhat "hysterical" traits. Given Benjamin's description of the effect that the very texts that he had studied in preparation for writing the Trauerspiel book can have on the reader, it should come as no surprise that he too (Benjamin) recalls his own "vertiginous" state at the end of the "Erkenntniskritische Vorrede" (Epistemocritical foreword) of his own "post-Baroque" essay. There he writes of the "Schwindelgefühl" (feeling of dizziness) that accompanies the reader when he confronts the contradictory, even "antithetisch" (antithetical) patterns of the period's most characteristic texts. By subscribing to what Benjamin calls an "asketische Schulung" (ascetic position) which both abjures totalizing analyses and refuses to "aus den Höhen des Erkennens in die ungeheuren Tiefen der Barockstimmung sich hinabstürzen zu lassen" (plunge from the heights of understanding into the monstrous depths of the Baroque mind), the scholar of these texts can nevertheless "[sich] zu der Festigung führen" (steady himself) and not reproduce that mind in a dizzyingly mimetic way. Uwe Steiner has associated this ascesis with Benjamin's critical deployment of philology. ${ }^{4}$ The letter to Scholem of 1924 confirms that Benjamin conceived of the "Erkenntniskritische Vorrede" as the location of this effort, which he describes as relying upon a somewhat "Romantic" "Begriff von Philologie" (concept of philology).

What Benjamin may have meant by this concept and how his method- 
ological choices in the Ursprung des deutschen Trauerspiels may have been philological ones still needs to be investigated in greater detail. ${ }^{5}$ Nevertheless, there are many moments in his study that call attention to a more traditional understanding of the work that philology could and was doing at the time that he wrote. In the final footnote of the "Vorrede," for example, Benjamin cites Wilhelm Hausenstein's Vom Geist des Barock (On the mind/spirit of the Baroque), which he appears to have read in an edition of 1921, as his source for his description of the "antithetical," complex, and destabilizing nature of Baroque texts. He may well also have been thinking of the title of another essay that he read during his preparations, "Barock als Gestaltung antithetischen Lebensgefühls" (The Baroque as the formation of antithetical life feeling/energy), published in the well-known journal Euphorion by Arthur Hübscher in 1922. Benjamin cites Hübscher somewhat earlier in the "Vorrede," and then again several times in the course of the book, as an example of yet another study that, along with Cysarz's, influenced his own project in significant ways. Citations from the texts of these three scholars in fact pepper the footnotes to the Ursprung des deutschen Trauerspiels, along with references to the work of Willi Flemming, Carl Horst, Julius Petersen, Fritz Strich, Julius Tittmann, and even Conrad Müller, whom we remember as the author of an 1882 study of Lohenstein who found the playwright's use of learnedness in the production of his perverse plays so offensive. Along with a battery of references to the work of other now more familiar names, such as Franz Rosenzweig, Aby Warburg, Erwin Panofsky, and Fritz Saxl, these late-nineteenth- and early-twentieth century Baroque specialists formed the intellectual community with which Benjamin dialogued - at least on paper - in his book; virtually unknown outside of a small circle of scholars today, the work of Cysarz, Petersen, and Strich, as well as the others, nevertheless belonged to the veritable industry of criticism about the early modern period that developed in the first several decades of the century, the academic center of which was in fact Berlin. Lohenstein's plays figured as prominent objects of analyses for these men. ${ }^{6}$ When Benjamin wrote, then, to Scholem that he would develop a theory of philology in his approach to the texts of the "Second Silesian School," he was in good, if mixed, company. That is, although it cannot be said that all of these critics shared a single methodology, they all sought to use the tools of the trade as they existed and were in the process of being reinvented by the academy at the time to steady themselves as they approached the uneven, even uncertain terrain and "Neuland" (uncharted lands) of the Baroque. ${ }^{7}$ This was one of the broader intellectual communities into which Benjamin thought to insert himself, then, by applying his version of philology to the Silesian Trauerspiel. ${ }^{8}$ 
Benjamin's description of the post-Baroque vertigo of Cysarz's study - "ein Stückchen Nachbarock" - that must be contained by the intervention of philology is nevertheless somewhat at odds with a later formulation of the form and function of the "Nach-," or "post" and "afterlife" of texts, where he appears not to need or want to contain their energies in quite the same way. In an essay about Eduard Fuchs that appeared in Zeitschrift für Sozialforschung (Journal for social research) in 1937, Benjamin writes, referring to a letter from Engels to Mehring: “Diese Werke integrieren für den, der sich als historischer Dialektiker mit ihnen befaßt, ihre Vor- wie ihre Nachgeschichte-eine Nachgeschichte, kraft deren auch ihre Vorgeschichte als in ständigem Wandel begriffen erkennbar wird" (For the critic who approaches works using historical dialectics, they [the works] contain both their pre- and posthistory, a post-history that, moreover, enables him [the critic] to perceive the prehistory as implicated in a constant process of change). ${ }^{9}$ What the post- reveals, then, according to Benjamin, is the impossibility of reproducing a single or stable "original" reading or text - through philology or by other means-precisely because the more closely one looks, the more mobile the object itself becomes, participating in both its own past and in the present at once. The protean condition of textual works that appears in and is the result of the kind of dialectical approach that Benjamin describes here would, of course, have been nowhere more apparent to him than in the very early modern books out of which he had copied so many excerpts during his months in the Staatsbibliothek in Berlin. As he familiarized himself at the same time with current criticism on the period, he would have been forced, moreover, to confront the myriad ways in which its prehistory in early modern poetological, philosophical, historical, political, and art-historical discourses had recently been released in such great quantities onto the pages of numerous post-Baroque studies, including his own, as a result of "philological" efforts, however defined. The sight of these multiple and densely interconnected textual and methodological universes might well have caused the dizziness of which he writes.

The dialectic between Benjamin's "philology" in the Trauerspiel book - between the embeddedness, that is, of his study in the fraught world of literary, philosophical, art-historical, and political studies of the Renaissance and early modern periods at the turn of the century, and the actual Baroque texts by Lohenstein, Gryphius, and others that he read - has begun to be studied by scholars such as Klaus Garber and Uwe Steiner. Reinserting the Ursprung des deutschen Trauerspiels back into the "thicker" world of texts out of which it grew and to which it alludesindeed, perhaps also tracking its ironic "afterlife" into the pages of later National Socialist-approved scholarship of the Baroque-could inter- 
vene in the image of Benjamin that the late twentieth century had made for itself by placing it in dialogue with several new sets of figures and ideas. Excavating the ghostly Nachleben of Benjamin's book at such specific locations and textual sites, for example, as two studies much lauded in Nazi-identified or at least Nazi-tolerant publications, namely Erich Trunz's magisterial "Die Erforschung der deutschen Barockdichtung. Ein Bericht über Ergebnisse und Aufgaben" (Researching German Baroque literature: A report on results and future tasks) and Erik Lunding's Das schlesische Kunstdrama (The Silesian art drama), both published in the very same year that Benjamin took his own life rather than be arrested by the Gestapo, allows us to observe how the mobility of literalmaterial and ideological-discursive conditions that characterizes all philological projects can produce such strange post-Baroque bedfellows as these. ${ }^{10}$ Conversely, the version of the Baroque that Benjamin gives us could lead to new ways of allowing a late-twentieth-century criticism obsessed with Benjamin to understand the importance of the historical texts of the Second Silesian School to his almost presciently postmodern ideas. Yet another "Stückchen Nachbarock" may emerge as a result.

\section{Lohenstein on the Border: Klaus Günther Just's Cold War Edition}

For Benjamin, a dialectical approach to texts recognizes and accepts that they belong to both the past and the present, to both the vor and the nach, and are thus in some sense always unstable, as the constantly shifting layers of historical identity and significance move in and out of focus depending on where one stands and when one looks. The texts of Lohenstein's plays, which Benjamin appears to have known in at least two early-eighteenth-century editions, would have provided him with a perfect example of this kind of mobility, not only in the relationship between the texts and the notes of the plays that I have examined, but also in the very material identity of the editions that he used, editions that, dating from 1708 and 1724 respectively, were clearly "not one" either with one another or with their historical "originals." If not already apparent to him in the palpable "history" of the books themselves, the impossibility of ever pinning down a text for good, so to speak, would surely have emerged out of the comparison between these editions and the versions in which he read the plays of two other great Silesian playwrights of the period, namely the 1684 edition of Johann Christian Hallmann and the 1882 edition of Andreas Gryphius, as they lay before him at the Staatsbibliothek. Sandwiched in between the seventeenth- and 
nineteenth-century editions of Hallmann and Gryphius that he used, Benjamin's eighteenth-century Lohenstein filled in the missing century, so to speak, eloquently registering the multiple "afterlives" of Baroque texts as they appeared in successive centuries and editions, each a new instance of the "Nachbarock."

Text-editing work is of course one of the most philological of tasks. Moreover, even though the production of a historical-critical edition, for example, could be said for the most part to be premised on the alleged proximity of the edition to its "origin" in the author's hand, recent theorizations of textual criticism by Tanselle, McGann, and Greetham, among others, have problematized those strains of neo-Lachmannian editorial practice that would claim to reach back to and stabilize the text with scientific precision in any final way. ${ }^{11}$ According to these theorists, postmodern philological practice in fact produces not "resolution" about the original state of a text but, rather, only "more knowledge and more, not fewer, choices" about its genesis and the relation of any given historical textual state to future versions. ${ }^{12}$ The three-volume Lohenstein edition produced in the mid- to late-1950s by Klaus Günther Just has been perceived as outdated and, indeed, decidedly unpostmodern; yet, it captures the volatile conditions whereby all texts are produced in ways with which contemporary text-editorial theory would be familiar. ${ }^{13}$ In the process, Just's Lohenstein reveals the inevitability of an "afterlife" for early modern texts in another way too, different perhaps from Benjamin's, yet just as much implicated in the production of yet a further piece of the post-Baroque. Just's philological work lies between Benjamin's and my own and illustrates how changing social, critical, and political practices and events enter into the very matter of texts in ways that continually unsettle what we see when we look at them.

Just's own location is not unimportant for understanding his editorial work. Born in Berlin in 1923, he grew up in Lohenstein's city of Breslau, and came of age as National Socialist Germany reached its heyday and then collapsed. ${ }^{14}$ The son of a professor of anthropology, who became one of the Reich's most productive researchers on race and heredity, ${ }^{15}$ he appears to have returned to Berlin to attend school, as the family followed the father in a series of career moves. Just spent the immediate aftermath of the war in Würzburg writing a dissertation on Stefan George. After 1948, he became immersed in a project based on carefully tracing the textual lineages and cataloging the material remains of Lohenstein's corpus and intellectual world in preparation for writing his own postdoctoral thesis, or Habilitationsschrift. He spent some time in England at Cambridge University and at the University of Leicester in the early 1950s; after finishing the last of the three volumes of the Lohenstein edi- 
tion in 1957, as well as the interpretive essay on the plays, Die Trauerspiele Lohensteins. Versuch einer Interpretation (Lohenstein's tragedies: A tentative interpretation) that he was required to hand in as part of his Habilitation, Just was appointed in 1961 to teach at Münster and, then, in 1964 , at the newly founded university at Bochum, where he taught until his untimely death from cancer in 1977 at the age of fifty-four. While a systematic exploration of the complex realities of postwar and Cold War literary studies in the German tradition as evidenced in Just's career goes beyond the parameters of this book, it is important to indicate briefly here how the political and ideological contexts of postwar literary and philological studies become visible in the editorial work with which he was engaging as he worked on his version of Lohenstein during these years. ${ }^{16}$

Just's scholarly work and his engagement with Lohenstein in particular were supported by a variety of government and private agencies after the war, many of them founded to deal with both the ideological contamination and literal devastation of Germany's intellectual and cultural inheritance during the period of National Socialist hegemony and the reconstruction of a specifically West German literary studies after 1945. His editions of Lohenstein's plays thus came about in a period as fraught with ideological and material tensions as the period that originally produced them. The de-Nazification of the universities and reestablishment of the institutions of academic publishing were controlled, for example, by the occupation authorities, who also had jurisdiction over printing permissions, paper allocation, and standards of political correctness. The division of the nation, the currency reform, and the onset of the Cold War had as much of an effect on the work of philology in the post-1945 period as the complicated relationship of German humanistic studies at the university level had to its past of complicity with Hitler's propaganda machine. All of these forces become visible in the texts of Lohenstein's plays that Just produced.

The history of National Socialism, the war, and its aftermath are everywhere apparent in Just's "philological" project. In a footnote in the foreword to the 1953 edition of one of Lohenstein's Turkish plays, Ibrahim Sultan, for example, Just indicates that he had written to the librarians at Breslau to try and locate the original manuscripts of the play; the gesture was a legitimate editorial one and also plausible, given the playwright's high profile and political prestige there. Just reproduces in a note the text of the letter that he received in response to his inquiry: "Von den über 5.000 Manuskripten der früheren Stadtbibliothek sind nur etwa 1.800 gerettet worden und diese in einem beklagenswerten Zustand. Sie waren in die Gegend von Oels ausgelagert worden, wo sie, 
auf dem Felde verstreut liegend, zum Fenster hinausgeworfen, feucht aufgefunden wurden" (Of the more than 5,000 manuscripts of the former City Library, only approximately 1,800 were saved, and these are in lamentable condition. They had been transferred for protection to a location near Oels, where, having been thrown out of a window, they lay strewn about on the fields. There they were found, damp and befouled). ${ }^{17}$ It must have been the realities of the absent "originals" that persuaded Just to base his edition exclusively on the collation of print versions. He proposes to favor the earliest imprints above all, he writes in the introductory essay on his method; these are the closest, he states, to the "ursprünglichen ... Gestalt" (original form) of the text as it exists "in untrennbarem Zusammenhang mit dem innersten Wesen" (inseparably connected to the innermost essence) of the work. ${ }^{18}$ This "essence," if it is to be identified with the "original" plays from Lohenstein's hand, was of course quite literally absent, as the letter from Breslau reveals. In its place entered the dialectic of history, the three to five subsequent versions of the plays, from the seventeenth through the early eighteenth centuries, including the editions that Benjamin read, all of which Just cites in a complicated and confusing editorial apparatus at the bottom of each page. There, the many variants and alternative readings compete for the reader's attention with the main text above, which Just nevertheless paradoxically designates as "kritisch gereinigt" (critically purified) in his introductory remarks. ${ }^{19}$ Like the texts of the countless ancient poets and historians, then, whose importance for Lohenstein Just inventoried in his monumental "Register" of the plays' sources in the volume containing the Roman plays, his (Just's) attempt to "castigate" the playwright's oeuvre ultimately "contaminates" it by allowing its multiple afterlives to intervene in and condition his philological work.

The deep implication of Just's philology in the post-Baroque context of postwar Germany becomes even clearer when we look to the dedicatory matter of the first of the volumes, the Türkische Trauerspiele, published in 1953. The dedication reads: "Herrn Professor Dr. Hermann Schneider Der in Lehre und Werk die Einheit der deutschen Philologie Vertritt in Verehrung Zugeeignet" (Dedicated to and in honor of Professor Hermann Schneider, whose teaching and work represent the unity of German philology). The phrase "Einheit der deutschen Philologie" may appear puzzling at first, but it too may be understood as resonant with complex historical struggles, in this case, again at first glance, with the methodological and academic struggles and debates of the prewar period. These debates are the subject of a letter from Just to Schneider on October 4, 1951, in which Just not only reports to Schneider, who was the general editor of the series in which the Lohenstein volumes were to 
appear, on his progress on the edition, but also announces his intention to dedicate the first volume to him (Schneider) as well as to Wolfgang Stammler (Just ultimately dedicates the first volume to Schneider, the second to Stammler). Both Schneider and Stammler stand, in different ways, as models for younger scholars, Just writes, particularly in their efforts "die Einheit der deutschen Philologie zu wahren und die 'Trennung' von 'Germanistik' und 'Neuerer deutscher Literaturwissenschaft' als nicht vorhanden zu betrachten" (to preserve the unity of German philology and to ignore the "separation" of Germanistik from Neuere deutsche Literaturwissenschaft). ${ }^{20}$ His edition of Lohenstein's plays is meant to continue in this tradition, and it is thus appropriate that he dedicate it to them.

The terms of both Just's dedication and of his letter to Schneider, and the distinctions that they seem to imply, refer first and foremost, as Wilfried Barner has shown, to the great divide between German philological study of the nineteenth century and, after approximately 1910, the more impressionistic and expressionistic kinds of literary interpretation and "history of expressive forms" practiced by Dilthey, Gundolf, and others. ${ }^{21}$ Barner quotes numerous documents from the 1910s and the 1920s rife with the tensions between "rigorous" philology and the more "youthful" work, tensions that were ultimately resolved with the victory of Geistesgeschichte over philology and the subsequent separation, methodologically and even institutionally, of medieval studies from the study of "modern" literature. In the dedication to Schneider, Just thus somewhat anachronistically locates his editorial efforts within an academic universe and theoretical debate that predated the very war whose aftermath had so impacted his text-critical work. His dedication of the first volume of Lohenstein's plays to Schneider in this way thus appears to want to use philology to deny the course of events. Yet it was Schneider's very devotion to philology in particular that had allowed him not only to survive the war but to obtain a position of influence after 1945 . Schneider's Tübingen colleagues state as much in the foreword to the volume issued in honor of his sixtieth birthday in 1946. That very survival was of course also a difficult achievement to acknowledge after 1945, as the editors of the Festschrift admit, since it implies either accommodation to or a denial of events that occurred after $1933 . .^{22}$ In spite of its appearance of wanting to simply elide and forget the war, then, Just's dedication of the volume to Schneider again only reveals both his and Schneider's implication in the war and its aftermath during a time when literary scholars and textual editors had to confront where their work-here, the Lohenstein edition-stood in relation to fascism.

Of course, the location of this particular afterlife of the Baroque in the 
postwar period is no place more obvious than in the very language used by Just in his dedication of the first Lohenstein volume. For when he writes of "Einheit" (unity) here, additional associations with the Cold War political context into which the edition was to be launched complicate the politics of Just's project in interesting ways. Some scholars would date the "beginning of the Cold War" to 1946 in association with Churchill's "Iron Curtain" speech in March of that year; in the German context, the division of what had been a German Reich into bilateral zones was of course already anticipated in 1945, as the Red Army swept across Poland to Berlin, and concretized before the end of the decade with the establishment of political and financial institutions in the Federal Republic, quite literally on the one hand, and the German Democratic Republic, on the other. When Just writes of "Einheit" in his letter to Schneider in 1951, the term resonates with attempts to memorialize a lost, perhaps even originally chimerical national unit just as inaccessible as the "original" Lohenstein manuscripts destroyed at approximately the same time. What is ultimately so fascinating about Just's editorial project, then, is that in spite of his apparent attempt to locate it in a prewar academic and scholarly context, indeed, in spite of his desire for a "unity" that would make retroactive developments that had occurred since peace had begun to be waged, the very possibility of the existence of his Lohenstein edition was thoroughly conditioned by its position within an already heavily bilateralized, post-Baroque world.

In a series of letters from between 1954 and 1957, the majority of which were exchanged between Hermann Schneider, one Herr Olbrich, who appears to have been the managing editor of Hiersemann Verlag in Stuttgart, and Ernst Alfred Philippson of the University of Illinois at Urbana, Just's edition of Lohenstein's plays emerges as the object around which an ideologically inflected, yet nevertheless also resolutely material and "historical" set of postwar and Cold War pressures condense. ${ }^{23}$ Originally conceived of as consisting in three volumes, the edition appeared over a number of years, as is well known; the letters document the complexities of those times. Schneider had arranged, for example, for a financial subvention from the "Kultusministerium" (Ministry of Culture) for volume 1 (Olbrich to Schneider, October 6, 1954); the "Zuschuss von 1,500, -" (payment of 1,500 marks) is characterized as the guarantor of the resuscitation of the long-standing series, the Bibliothek des literarischen Vereins, that had lain dormant for a decade or more. Olbrich of Hiersemann begins already in this letter to pressure Schneider to secure comparable support for volume 2. In November 1954, Schneider nevertheless responds that it is the responsibility of the press to initiate such a request. By April of the following year (1955), volume 2 has ap- 
peared; yet neither Schneider's correspondence nor any records at Hiersemann appear to indicate whether and, if so, from whom any support was secured. Already in October 1955, however, ominous signs creep into the ongoing discussion between Schneider and Olbrich about future plans; in a letter from October 1, for example, Schneider writes in response to a now missing letter from Olbrich that Olbrich's news has disappointed him, since it (Olbrich's letter) "stellt ja nicht mehr und nicht weniger dar als das Grabgeläute für den Stuttgarter Literarischen Verein" (indicates nothing more and nothing less than the demise of the Stuttgart Literarischer Verein), a series that "sich um die germanistiche Wissenschaft doch nicht ganz unerhebliche Verdienste erworben hat" (performed not inconsiderable services for the discipline of German literary studies). We can assume that plans for the publication of volume 3 of Just's edition of Lohenstein were now under discussion and that Olbrich had communicated to Schneider that financial considerations were jeopardizing the future of the edition and of the series itself. The work of philology in connecting with history, as problematic as it may have been in Just's theory and practice, was now in danger of not being completed.

While the exact chronology and sequence of events are somewhat unclear in the fragmentary correspondence that has survived in the Hermann Schneider Nachlaß, what follows in the summer of 1956 is a series of letters between Schneider and Ernst Alfred Philippson of Illinois concerning the possibility of a further edition of a different Baroque author. For obvious reasons, the threat of the cancellation of the completion of the Lohenstein edition plays a large role in their negotiations. Philippson's letters express concern, with specific reference to Just's work, that the series itself "mit dem Tode ringt" (is wrestling with death), since the Literarischer Verein, with its more than 120-year history, represents "ein literarisches Kulturgut" (a literary-cultural asset) of central importance to Germany (Philippson to Schneider, June 19, 1956). Within ten days, Schneider has forwarded a copy of Philippson's letter to Olbrich, with the suggestion that "[d]ie Amerikaner bringen der Sache mehr Interesse entgegen als in Deutschland der Fall war" (the Americans are clearly more interested in the project than is the case in Germany) (Schneider to Olbrich, June 29, 1956). Just a short time later (July 12, 1956), Schneider contacts Olbrich once again to underscore the "Interesse von gutem Willen der amerikanischen Herren" (interest and goodwill shown by the American gentlemen) for the success of the series. He hopes Hiersemann will reconsider its plans for the last Lohenstein volume in particular "angesichts dieses überseeischen Interesses" (considering this interest from overseas), which, he assumes, as was perhaps logical in this 
post-Marshall Plan era, will be accompanied by "die erforderlichen Mittel" (the necessary means) for the "Verwirklichung dieses Gedankens" (realization of this thought). Hereafter, the record again becomes spotty, except that Schneider writes to Philippson again toward the end of July (July 21, 1956) with the disappointing news that " $[\mathrm{u}]$ nserem Plan einer möglichen Wiedererstehung des Literarischen Vereins ... stehen, wie sich jetzt herausstellt, unüberwindliche Hindernisse im Wege" (our plan for the possible resurrection of the Literarischer Verein ... appears now to have met insurmountable resistance), and that he (Schneider) is pained indeed that "der wissenschaftliche Kontakt zwischen Alter und Neuer Welt, der sich auf dem Boden der Barockliteratur zu gestalten schien, nun doch nicht Wirklichkeit werden kann" (the scholarly contact between the Old and the New Worlds that seemed to be taking form on the basis of Baroque literature, will now no longer be able to become real). The series and edition that were previously, at least in Just's mind, to bring - in an almost Benjaminian gesture - the past of prewar German academic culture into the present (or, perhaps, to bring that present back into the past) in the form of a text, are now transformed into the cement that was to hold the future of a postwar partnership between Old and New Worlds, former enemies and now allies, together. The multiple levels of the post-Baroque afterlives of Lohenstein's plays are almost too many to count here.

Schneider's regrets refer in all likelihood to Philippson's edition of Neukirch's anthology of Baroque poetry, which was eventually published by Niemeyer of Tübingen in 1961. Yet the third volume of Just's Lohenstein did in fact appear with Hiersemann just one year later in the spring of 1957. No record appears to survive of who may have provided the necessary subsidies, but a letter from Schneider to Olbrich on June 4, 1957, does exist in which he thanks Olbrich for having sent him an advance copy of the book. ${ }^{24}$ Schneider praises the quality of both the edition and the text and expresses his gratitude that, in its dedication to the project, the press "[hat] der dramatischen Barockforschung einen weiteren und weiterführenden Aufschwung verliehen" (has given studies of Baroque drama a further and very promising impetus for the future). Schneider also adds his personal thanks that the volume has appeared "in den Rahmen des Literarischen Vereins . . . trotzdem dieser seither nicht mehr eigentlich in Erscheinung tritt" (under the rubric of the Literarischer Verein, in spite of the fact that it actually no longer exists). The appeal to the interest of the "Americans," perhaps even to a financial commitment on their part, thus seems to have worked to allow the completion of an edition that signified the renewal of German Baroque studies after the war. This renewal and, indeed, the edition itself, were 
thus inscribed in a postwar/Cold War economy of both material and ideological dimensions, in which linkage to American interests ensured that an edition of Lohenstein's plays would appear.

Of course, the Cold War had two sides; the post-Baroque event of the 1950s Lohenstein edition thus had another dimension as well. For if we remember that both Lohenstein and his editor, Klaus Günther Just, were originally closely affiliated with Breslau, now in Poland, in the Land of Silesia more often than not (although now no longer) designated as culturally "German" over the past hundred years, the choice of Lohenstein as the figure around whom to constellate these various postwar and Cold War editiorial choices begins to make sense. It is in fact Lohenstein's hailing from Silesia that is said to have appealed to Just in his selection of the plays as the subject of his postdoctoral thesis, for example. ${ }^{25}$ Indeed, in 1960, some time after he completed the edition and the year in which he finished his monograph on Lohenstein, Just published an excerpt from its introduction in volume 6 of the yearbook entitled Schlesien, in which he defines Lohenstein first and foremost as a "Schlesier" (Silesian), then as a "Deutscher" (German), and, only in third place, as an "Europäer" (European). ${ }^{26}$ It is clear, as Just writes in a book review that appeared in the same number of the yearbook, that anyone interested in the German Baroque will have to "ihr Augenmerk auf Schlesien richten" (turn his eyes toward Silesia), since "fast alle grossen deutschen Barockdichter waren schlesischer Herkunft" (nearly all of the great German Baroque poets were of Silesian descent) ${ }^{27}$ It is, moreover, Just continues, all the more important for scholars to do so at the present point in time, in 1960, that is, for, as he writes: "[s]eit dem Verlust Schlesiens ist es deutschen Gelehrten nicht mehr möglich, in schlesischen Bibliotheken und Archiven zu arbeiten" (since the loss of Silesia, it is no longer possible for German scholars to work in the libraries and archives there). These claims are not innocent, it is clear, and pull Lohenstein directly into another post-Baroque moment, namely the debate about Silesia in and after 1945.

Although the chronology would surely look somewhat different from the Polish perspective, which would characterize the "loss of Silesia" as one that had occurred in ongoing fashion for some three hundred years and, most recently, both during the war at the hands of the Reich and after 1945 at the hands of the Soviets, Just is clearly referring in his remarks to the situation as it appeared to postwar/Cold War West Germany. From this perspective, Silesia had of course been lost for good in 1945, when what had been both culturally and politically German territory came under Polish and hence Soviet influence; the historiography 
of the death of some 1.5 million ethnic Germans and of the Vertreibung (driving out, expulsion) of an additional 8 million from Silesia at the end of and after the war is daunting and preceded Holocaust studies in Germany by a good twenty years. ${ }^{28}$ The finality of this loss had become more and more obvious in the following years as Soviet dominance continued to grow even in the face of Polish opposition. The journal Schlesien had in fact been founded in 1955 in order, according to the statement by its editors printed in each subsequent volume, to function as "ein Sendbote Schlesiens, der die Schlesier ebenso wie das gesamte deutsche Volk und das Ausland anspricht" (an ambassador of Silesia designed to appeal not only to Silesians, but to all German peoples as well as to the external world at large). It was to tell "von seinem Volkstum und von der Seele des schlesischen Menschens" (about the [Silesian] Volk and the Silesian soul). ${ }^{29}$ That the journal was published in Würzburg by an organization called Kulturwerk Schlesien testifies to where the Silesian "soul" and true Silesians were assumed to reside at the time, namely in West Germany, exiles from the homeland from which the "Iron Curtain" appeared to have separated them once and for all. Just's commitment to the journal (he published numerous reviews and short essays there) accords with his commitment to the Lohenstein edition, then. His interest in preparing a new version of Lohenstein begins to make sense as a moment in the updating, so to speak, and preservation of Silesian culture in the face of its "disappearance" into the east bloc in the postwar years.

The first volume of what eventually became the three-volume edition of Lohenstein's plays thus marked the rebirth after a ten-year hiatus of a prestigious series of critical editions of German authors, the Bibliothek des literarischen Vereins, which had first begun to publish in 1839, but had ceased publishing during 1943, when all resources had to be devoted to the total-war effort. Hermann Schneider, the dedicatee of volume 1, was the general editor of that series; he had been the last rector of the university at Tübingen under the Nazis and was also its first rector after the war. Schneider chose to reinaugurate the series as one of the first building blocks of a new (West) German literary studies by asking a young scholar, Just, to complete what had apparently already been planned more than a decade earlier, namely an edition of Lohenstein's bizarre Silesian plays. Perhaps Schneider made these choices because Just had connections to England and could thus build bridges to foreign countries and scholarly communities. Or perhaps he already knew of the interest on the part of several U.S. American professors in the Baroque, an interest stimulated by the presence in the United States of at 


\section{Conclusion}

least one major collection of early modern German-language books (including editions of Lohenstein's plays) at an elite U.S. university, a collection "rescued" from the devastation of both World War II and the postwar division of Germany by its owner, Curt Faber du Faur, who left Europe with his books in 1939, and first loaned them to Harvard and then finally gave them to Yale in $1945 .{ }^{30}$ Perhaps the publisher, Hiersemann, was merely responding gratefully to the possibility of American subsidies for these volumes of arcania. Or perhaps Olbrich had originally been interested in preserving some of the "heritage of the West" from invisibility due to what were surely perceived at the time as obstacles thrown up to western endeavors by Soviet-influenced actions in former Silesia; Hiersemann was, after all, originally a Leipzig publishing house and had relocated to the West and to Stuttgart only after the war. The more closely we look at the "origins" of this most recent version of Lohenstein, then, the more difficult it is to pin down any one of these as the reason that Just's "Stückchen Nachbarock" came about.

Like the work of the man to whose plays he devoted at least ten years of his life, Just's edition thus emerges as a historically "thick," somewhat "messy" project designed to create a rich afterlife for Lohenstein, even as he is said, in the words of a colleague, to have considered it the ultimate task of an almost disengaged, even rarefied "philological virtue" to edit the texts of the famous poet of his childhood town. ${ }^{31}$ What is the effect of this intersection of politics, morality, and philology, of the production of "virtue" by means of "managing" the memories of exotica, both in the early modern period and during both World War II and the Cold War? Text collection, particularly the collection of the marginal, the obscure, and the apparently outlandish, can serve to "fill in the gaps" of national heritages, it is true. But such efforts can also expose how these legacies were constructed in the first place, what ends they have served, and what had to be left out for that national image to emerge. As historical documents in several historical locations, written for the early modern transvestite school stage, received and read with enthusiasm in the late nineteenth and early twentieth centuries by Benjamin and the countless scholars and enthusiasts whom he cites in his notes to the Trauerspiel book, (re)produced, finally, in a Cold War world fascinated with yet materially constrained by boundary events of several kinds, Lohenstein's learned plays about powerful women occupy a number of historically specific post-Baroque positions. These multiple locations within the several scholarly economies to which I have pointed allow them to travel over one final set of borders and mapping effects, namely that of mid- to late-twentieth-century early modern studies, into 
our own post-Cold War world, and indicate my own investments in rereading these plays in a "centering" way.

\section{Recentering Europe in Early Modern Studies}

The hybrid nature of gender identity is clear in Lohenstein's plays, which were acted by boys playing women. The presence of a massive critical apparatus makes it unclear, moreover, where the origins of that identity are ultimately to be found, whether they lie in the past or the present of Rome or early modern Silesian Breslau, for example, at the center or in the margins of these texts and their learned notes. The location of the texts themselves at the margins but potentially also at the center of a reconsideration of the construction of gender in the early modern period is thus not surprising, since the center-margins dynamic is what most characterizes the very matter of the plays. What might appear to be their peculiarity brings into focus the historical conditions by which a more general exclusionary disciplinary economy created the traditional image of that period. In the United States, this image has traditionally - and not surprisingly - found its center and definitional principles in a clear binarism of West-oriented, court-based and, in large measure, Italocentric and Anglophone national idioms and textual projects, on the one hand, and a more or less shadowy "everything else," including the cultures of southern, central, and northern Europe, on the other. The historical construction of a period concept in this way as well as the nonreception of figures like Lohenstein and the ghettoization of the Spanish and Dutch traditions, for example, is well worth considering as we begin to articulate the future of the academic study of (the earlier cultures of) Europe at large in the late-twentieth-century academic world.

Much debate in the United States during the 1980s and early 1990s about the origins of an ethno- and androcentric canon focused on critiquing the production of literary histories out of and as monuments to historically specific hegemonic communities and "regimes of knowledge." The predominant image of a monolithic early modernism or of nation-state-based and court-oriented Renaissance(s) stands in need of a similar critique, especially in view of the field's tendency to define itself and its "proper" objects of knowledge along partisan geographical axes rather than along somewhat more complex, indeed confusing lines and faults. This tendency began, I would argue in all too sweeping terms, with nineteenth-century nationalist and internationalist ideologi- 
cal needs for clear lineages of "Europe"'s high cultural inheritance and the legitimation of imperial consolidation and expansion both in England and on the continent. Based on and facilitated by what Kathleen Biddick has called "fantastic scholarly geograph[ies]" and chronologies, these "pure" lineages enabled the individual states of (western) Europe to embark on ideological missions of tradition building without fear of either "native" contamination or internal resistance..$^{32}$ Maps and histories of "the Renaissance" in particular produced a general organization of knowledge about early modern European cultural history that yielded a series of discrete exercises in local knowledges without a global component, on the one hand, and "macro"-narratives of total culture without the benefit of details, on the other. ${ }^{33}$

The dissemination of such academic economies of interest and study to the United States in particular was not disturbed but was, rather, enhanced by the international migration and circulation of scholars during and after World War II, whose personal and institutional histories allowed versions of the period to emerge that reflected very specific political, ideological, and cultural investments and material constraints on the level of both individual objects of study and methodology. ${ }^{34}$ After the war, scholars worked frantically to "center" and stabilize the ruins of western cultural identity by inventing a universalizing, civilizing narrative of "the common heritage of the (non-Soviet) west" inherited and to be defended by the United States after the conflagration of two European wars. ${ }^{35}$ European scholars in exile tailored their versions of the Renaissance to fit this image and set of ideological needs. A history of the construction of Renaissance and early modern studies that considers these and similar factors needs to be written.

Although recent attempts to envision a "longer" and perhaps even "deeper" early modern period in particular have succeeded, even if in contestatory fashion, in unsettling some of these inherited disciplinary distinctions about what one studies when one studies "the Renaissance," they have for the most part left un- or underanalyzed the imaginary borders that constrain how we work. These borders became formalized and institutionalized by colleges and universities in the United States, for example, at specific historical times and places in such a way as to render difficult (although not impossible) the consideration of a postcolonial Renaissance studies, for example, an enterprise that would require the cooperative efforts of English and Spanish departments in the study of an "Atlantic" Renaissance, perhaps, or the collaboration of Africanists, Hispanists, and Germanists to consider the afterlives of Jesuit interventions in the cultures of Ethiopia and Egypt in the sixteenth and seventeenth centuries that I begin to address in chapter $4 .{ }^{36}$ The dis- 
ciplinary segregation that spawned the study of discrete national literary traditions, each caught in a trajectory that posits a homogeneous culture as the necessary expression of a unified national identity, ironically also created the conditions whereby philology became estranged not just from literary theory and criticism and "interpretation," but also from the history of religion, political theory, and, more recently, cultural and gender studies, to name but a few. These developments are ironic, because historically it had been the achievement of a "positivist" philology to have offered (perhaps despite its intentions) empirical "proof" of the density, complexity, and heterogeneity of specific national cultural legacies, patterns of thought, and preferred formal and stylistic traditions. A post-Cold War, perhaps internationalist, and at the very least intercultural "recalibration" 37 of the mechanisms with which we measure the relative importance and necessity of specific objects of study, including the artifacts of the early modern period, is slowly becoming overdue.

One particular legacy of the Cold War in this now truly anachronistic project of intellectual atomization in the United States has been the nearly universal maintenance in early modern literary studies of disciplinary and linguistic borders somewhere well west of the Oder, if not also of the Rhine, and south of the Alps, such that the historical center of Europe in the middle of the continent began to appear to be on the margin or, quite literally, beyond and behind the border of what could or should be known about the period at all. Designated even by German scholars as recently as 1995 as geographical "terra incognita" within disciplinary genealogies of German literary studies, ${ }^{38}$ both the early modern and the more general literature and culture of eastern central Europe functioned in the early part of this century (in the development of what understood itself to be in the first instance an antipositivist turn) as the laboratory or site of methodological experimentation; yet its status, again, as terra incognita ${ }^{39}$ (the frequency with which this term is used is striking), permitted an "Expressionist Baroque" to emerge that even Benjamin in 1927 considered to have left the texts and the period shrouded in misunderstanding. ${ }^{40}$ Other, less overtly ideological, earlytwentieth-century attempts to integrate the apparently "minor" literary and cultural traditions that flourished in German (not to speak of Polish and Czech, for example) into genealogies of the period based on their relation to categories derived from art-historical Renaissance studies, for example, functioned in similar fashion to keep the texts themselves, now construed as either poor cousins, late bloomers, or epigones, at a safe distance from close analysis. ${ }^{41}$ The ease with which such apologies were then rejected in favor of celebratory narratives about both heroic 
German poetic spirits and the vigor of a national language and "race" already visible in the earlier periods of course contaminated German studies both on the continent and in the U.S. for decades after both wars. ${ }^{42}$ The marginalization of central European cultural production of any and all periods was the result.

Russell Berman has argued that "the future of German cultural history is likely to include some hard core archival work, positivist data collection." 43 While he is clearly talking about the opening of the archives of the former East German secret police, the Stasi, made possible by the fall of the border to the East in 1989, the extent to which "positivist" methods such as philology may stand to be redefined in a post1989 institutional and political academic landscape poses some interesting questions. The "opening" of the territories of eastern central Europe has not only made available archives and traditions of scholarship about early modern Europe inaccessible to the West for some fifty years but may also be able to expose the westward "tilt" of occidental early modern studies during this same time. In a post-1989 world, it becomes increasingly difficult to persist in sustaining the hierarchies that came to organize the study of literature during this period (such that the "natural" languages of literary study in the United States, for example, are those only of western Europe) ${ }^{44}$ by focusing on periods that seem either to have stopped at anachronistically conceived geographical borders or that were organized by nation-state. Such geographies of knowledge merely reproduce ideologically invested cultural landscapes, formations of knowledge, and relations of power, whereby western Europe is seen as homogeneously "more advanced" than its "chaotic" and, in the many senses of the word, heterodox and "undisciplined" eastern partner. ${ }^{45}$ When the "center" of Europe shifts eastward, however, and moves back into the greater Eurasian continent-with its complex racial, confessional, and political worlds - we are confronted with heterogeneous relations of culture, loyalties, and power, relations expressed in our own time in the reemergence of nationalisms, regionalisms, and local chauvinisms, yet also by inter- and transnational legacies and movements of culture. In the early modern period, the continent was shaped by similar struggles between both the Holy Roman and the Ottoman Empires and between England, France, Sweden, and Poland, to name but a few, as well as between local and state jurisdictions, confessional factionalisms, and the struggle to balance the often conflicting demands of international and local interests, commercial strategies, and civic political stability. In contrast to those versions of the early modern cultural tradition that represent the period as either the prototype for or the high point of an orderly, "hesperizing," and civilizing turn, a more hetero- 
geneously conceived early modern Europe can function as a model for the borderland in the many senses in which that term is now used to describe the hybridity and contentiousness, yet also the richness of the postmodern world. With the clear recognition that "positivist" data collection was never uncritical or "objective," but served, even as soon as it was articulated as a method, to subtend interested narratives of the present, the opening to the east presents us with the opportunity to "mobilize" the study of early modern Europe in new ways by telling radically different stories about it. Looking to Lohenstein not as elegant exception to but precisely as a meaningful representative of this Europe may afford the late-twentieth-century academy with the opportunity to revise our ways of talking about wie es eigentlich gewesen at the early modern origins of "our" time. 



\section{Notes}

\section{Introduction}

1. Sedgwick, Epistemology of the Closet, 22.

2. The various ways in which we are said to produce our objects of study in the process of knowing them "objectively" is laid out by Megill, "Introduction." Fabian, "Ethnographic Objectivity," discusses knowledge production as a dialectical project of "objectification," of the making of the object of knowledge.

3. The nomenclature used to either compare or contrast Renaissance studies with and from early modern studies has been in flux for some time. Although I would dispute some of her claims, Leah Marcus's "Renaissance/Early Modern Studies" has been used to describe the terminological and methodological debate with some frequency. Nevertheless, the claims I am making about the distinctly westward list of most scholarship obtain for what Marcus sees as two different camps and approaches.

4. See White, Metahistory, 230-64.

5. The concept of "central Europe" is itself, of course, not a stable one and has been variously defined at different historical moments and by differing political and ideological needs. In 1915, for example, Friedrich Neumann used the term "Mitteleuropa" in a fashion that still resonated with the specter of German imperialism for many of the smaller, eastern European states. In the 1980s, the concept of "Mitteleuropa" was used by the Green Movement to indicate that ecological issues knew no political borders. Recently, the term has been revived again by theorists and historians in these states precisely to differentiate themselves from their post-World War II/Cold War pasts "behind the Iron Curtain." See Vajda, "Die Bedeutung," and Szucs, Die drei historischen Regionen, as well as Betz, "Mitteleuropa." As has become acceptable as one of the possible uses of the term, I refer with "central Europe" to the areas, along an east-west axis, between and including France and the former East bloc states and, along a north-south axis, between Italy and the nations of northern Europe.

6. This vision was "predicated on [a] partition" and bilateralized world whose era began coming to an end around 1989. For a discussion of the odd coincidence of "Renaissance Europe" with the European Community, see Pocock, "Deconstructing Europe," 300-301.

7. The claim of invisibility here refers primarily to the currency, or lack thereof, of Lohenstein's play corpus in critical and literary historical studies of Renaissance/early modern/Baroque culture in Europe. With the exception of scholars who have wondered briefly about the arcane texts to which Walter Benjamin refers in his Ursprung des deutschen Trauerspiels, in which the plays of Lohenstein and his compatriot, Gryphius, loom large, it is, moreover, only the 
occasional scholar of Renaissance or early modern studies in the United States who considers texts and issues other than those associated with Luther, for example, or Erasmus, as potentially relevant to claims made about the period.

8. Hayles, Chaos Bound, 2.

9. My project is in fact to challenge the notion of "marginal" areas of study across the several fields of Renaissance and early modern studies, German Baroque studies, and feminist histories of gender ideology. In so doing, I follow Hayles, as she points out the narrowing and ossification of categories of inclusion and exclusion in a fascinating discussion of textbook composition; there she notes the tendency of disciplinary communities to exclude "foreign" heuristics (57-58): "the ability of [all] heuristics to replicate themselves through several generations of textbooks is striking evidence of the effectiveness of disciplinary traditions in erecting boundaries that marginalize and trivialize what happens outside of them." The present project seeks to challenge just such disciplinary mechanisms of trivialization.

10. See Guillory, Cultural Capital.

11. See Hayles, Chaos Bound, 222-23.

12. See Wichert, Literatur, Rhetorik, und Jurisprudenz, 43-55, on the tradition of school dramatic productions in Breslau, and Asmuth, Daniel Casper von Lohenstein, on the actual dates and locations of the individual plays.

13. See Correll, The End of Conduct, 1-31, and Halpern, The Poetics of Primitive Accumulation, 19-60, for the development of these arguments about male subjectivity and the schools.

14. Chartier, The Order of Books, ix.

15. See Howard, The Stage and Social Struggle, and Laura Levine, Men in Women's Clothing, as two exemplary studies of the place of boy actors on the Elizabethan stage. Many subsequent studies in this area are based on earlier versions of Howard's and Levine's work.

16. See Landow, "What's a Critic to Do? Critical Theory in the Age of Hypertext," 23.

17. See Chartier, The Order of Books, and Slights, "The Edifying Margins," for fascinating elaborations of the double function of print.

18. Haraway's now classic treatment of this concept may be found in her "A Manifesto for Cyborgs."

19. See Pratt, Imperial Eyes.

20. Hayles, Chaos Bound, 221.

21. See Katie King, Theory in Its Feminist Travels. I am heavily indebted to King's arguments in this book and to her intellectual support for this project as well.

22. See Schaffer, "Gestures in Question," 98, for the call to challenge such "asymmetric" narratives.

23. Indeed, it was the pressure to "modernize," to "keep up" with cultural and curricular innovations, Guillory has argued, that produced the very syllabi and literary-critical vocabularies now challenged by a variety of postmodern critiques. Attending to and dwelling upon the "historical context" of cultural 
production necessarily brings the complexities and diversities of both historical and modern works into view. See Cultural Capital, 30.

24. On the discourse of "presentism," see Biddick, "Bede's Blush," and DuBois, Sappho Is Burning, 62-63.

25. On the isomorphism of literary and theoretical texts, see Hayles, Chaos Bound, 175-208.

26. Work on this book was substantially complete when I had the good fortune to read Marcus, Unediting the Renaissance. See her excellent discussion of what she calls "the new philology" and its impact on our acknowledging the "materiality of the text" there, 17-37.

27. Müller is cited in Just, Die Trauerspiele Lohensteins, 17.

28. For the "nationalist" Lohenstein, see Lunding, Das schlesische Kunstdrama, published, not surprisingly, in 1940, or, for the Silesian celebration of Lohenstein, see Just, "Lohenstein und seine Zeit," published in 1961 in the yearbook, Schlesien. For the political and ideological investments of these commentaries on Lohenstein, see my conclusion.

29. See Martino, Daniel Casper von Lohenstein, 175-435, for example, and Wichert, Literatur, Rhetorik, und Jurisprudenz.

30. For a related argument, see König, "Eine Rekonstruktion nach dem Bruch," 2, on the necessary "Re-Philologisierung" (rephilologization) of the cultural artifacts of eastern central Europe after their virtual invisibilization behind a curtain of western accusations of the "Sovietization" of all academic knowledge in the East during the Cold War.

31. An additional exception would be Wall, The Imprint of Gender, which explores the intersection of vocabularies of gender and textuality in a number of early modern English texts.

32. See Katie King, "Bibliography," 92-93, and Oellers, "Editionswissenschaft."

33. Jakobson is cited in Watkins, "What Is Philology?," 25.

34. See Freud, "Civilization and Its Discontents," 69-70. Also see Damrosch, "The Politics of Ethics," Marjorie Garber, Shakespeare's Ghost Writers, 52-54, and Ginzburg, "Morelli, Freud, and Sherlock Holmes."

35. DuBois, Sappho Is Burning, 37.

36. See Culler, "Anti-Foundational Philology," 50.

37. See Johnson, "Philology," 26-29.

38. DuBois, Sappho Is Burning, 164.

39. See Horstmann, "Philologie," and Grafton, Defenders, for dense introductions to this history.

40. On the genealogy of late-nineteenth- and early-twentieth-century classical and nationalist philology, see Barner, "Zwischen Gravitation und Opposition."

41. See DuBois, Sappho Is Burning, 164 and 55, respectively.

42. Ibid., 63.

43. Here, McGann, "Monks and Giants," 180 and 182, respectively, is quoting Wellek and Warren. 
44. See Williams, "I Shall Be Spoken," 50. The ironic reference to philological work as "drudgery" may be found in Williams, 45.

45. See Zetzel, "Religion, Rhetoric, and Historical Technique: Reconstructing the Classics," 110-11.

46. In his essay, "Philology and Weltliteratur," Erich Auerbach cites St. Augustine on the diversity that emerges out of the philological approach: "Philology, in this role, dominated all the historical disciplines because, unlike philosophy, which deals with eternal truths, philology treats contingent, historical truths at their base level" (2).

47. See Grafton, Defenders, 214-43. Also see Oellers, "Editionswissenschaft," 103 , on the "Alexandrine" tenor of our own critical practices and time.

48. Grafton, Defenders, 230 and 233, respectively.

49. See Jed, Chaste Thinking, 33-34. See also Tribble, Margins and Marginality.

50. See Rizzo, Il lessico filologico, and Kenney, The Classical Text, 71.

51. Saussure is cited in Watkins, "What is Philology?," 23.

52. See Geertz, "Thick Description," 31-32.

53. See Guillory, Cultural Capital, 70-71.

54. See Bakhtin, The Dialogic Imagination, 81-82.

55. See Ginzburg, "Morelli, Freud, and Sherlock Holmes."

56. Ibid., 11.

57. This is Diderot and D'Alembert's definition of philology in the Encyclopédie, cited in Horstmann, "Philologie," 556.

58. See Greetham, "Editorial and Critical Theory," 18.

59. The most recent and most challenging of the myriad scholarly treatments of early modern Roman inheritances from the point of view of gender can be found in Coppelia Kahn, Roman Shakespeare.

60. For fascinating treatments of the legacy of such scenarios from the fifteenth through the nineteenth centuries, see Greene, A Light in Troy, and Richard, The Founders and the Classics, respectively.

61. On the complex relationship between Breslau and Vienna and thus between Lohenstein and the task of representing Rome as a legitimation of the Holy Roman Empire's power, see Wichert, Literatur, Rhetorik, und Jurisprudenz, 135-59.

62. On the professional activities of these learned poets and dramatists, see Kühlmann, Gelehrtenrepublik und Fürstenstaat. On the position of Syndikus, see Wichert, Literatur, Rhetorik, und Jurisprudenz, 27-37.

63. See Burke, "A Survey of the Popularity of Ancient Historians," 135-52.

64. See Halpern, The Poetics of Primitive Accumulation, 176-90, for this interpretation of the traditions of scholarly annotation.

65. See Tribble, Margins and Marginality, 2.

66. Greetham, "Editorial and Critical Theory," 12.

67. For the distinction, see Koselleck, "Historia Magistra Vitae," 201-12.

68. See Halpern, The Poetics of Primitive Accumulation, and Ong, "Latin Language Study."

69. Although the plays were not officially part of the curriculum, they were related to the schools' ideological program. On Schuldramen, see Barner, Barock- 
rhetorik, 310-18; Eggers, "Das Breslauer Schultheater," 210-14; Schlesinger, Geschichte des Breslauer Theaters, 4-7; and Spellerberg, "Das schlesische Barockdrama," 58-69. The plays also appear to have been part of efforts by the schools and the city authorities to "manage" their young charges in a more specifically confessional moment of crisis. There has been some suggestion that the plays' excessiveness grew out of the need of the Protestant schools to respond to the infringements by the Jesuits on their student base and clientele, as well as to the traveling theater groups that frequented the city. See Wichert, Literatur, Rhetorik, und Jurisprudenz, 47-55, and Martino, Daniel Casper von Lohenstein, 112-13, on competing theater productions by the Jesuits. Also see Wichert, 18-27, on the relationship of the schools to the burgeoning need for civil servants, or Beamten, in this period.

70. On footnotes as revealing of "those parts of history which lie beneath ground level," see Grafton, The Footnote, 6-7.

71. The formulation is Halpern's in The Poetics of Primitive Accumulation, 22, although he is referring to learned culture in early modern England rather than central Europe there.

72. In the overview that follows, I have relied on several histories of Silesia, including Grünhagen's Geschichte Schlesiens (1884-86), Petry and Menzel's Geschichte Schlesiens (1988), and Conrads's Schlesien. Deutsche Geschichte im Osten Europas (1994). Although these too are overviews, each contains an excellent bibliography. Here I include notes only to specific references and direct quotations from these studies.

73. See Conrads, Schlesien, 28.

74. Parts of Upper Silesia, however, became more identified with Poland and Moravia during these years. In one small city there, the official language of government was in fact Czech after 1494 (ibid., 156-57). The differences between Lower Silesia, where Breslau is located, and Upper Silesia, closer to the traditionally "Slavic" lands of the Empire, will be discussed later.

75. See ibid., 262.

76. See Brilling, "Zur Geschichte der Juden in Breslau."

77. See, for example, the map of Silesia after the Thirty Years' War reproduced in Conrads, Schlesien, 289.

78. Ibid., 229.

\section{Chapter 1}

1. One thinks of Shakespeare's Roman sequence, as well of May's, Racine's, Mairet's, Daniel's, or Trissino's plays. A possible rival to Lohenstein's excessive treatments of matters Roman on the early modern stage can be found, however, in Shakespeare's Titus Andronicus.

2. See Kühlmann, "Geschichte als Gegenwart."

3. Rüdiger, "Die Wiederentdeckung der antiken Literatur," 539, writes of the "aktive Rezeption" (active reception) of classical traditions by the Moderns as one that manipulates the past while also repeating it. Pigman, "Versions of 
Imitation," examines the "filial" relations between ancient models and Renaissance texts in ways that suggest that these relations are gendered.

4. See Irigaray, "This Sex Which Is Not One."

5. Lohenstein's was of course not the only treatment of the Sophonisbe material; Axelrad, Le thème de Sophonisbe, cites some twenty-three texts between the sixteenth and the twentieth centuries. On the Renaissance and early modern receptions in particular, see also Ricci, Sophonisbe dans le tragédie classique.

6. Machiavelli had of course already seen the rise and fall of the Roman state as a matter of manipulating and containing women. See his Discorsi 3.26, and Pitkin, Fortune Is a Woman. Lohenstein presents this principle somewhat differently, since many of his figures exceed containment even though they die in the service of the state.

7. On the "conceptual plurality" and "discursive multiplicity" of history writing for Renaissance humanists, see Hampton, Writing from History, 31-80, especially 33. That history itself, as the "story" told about past events, had also in antiquity been conceived of as complex was known to early modern historians from their readings of classical texts. See Momigliano, "Tradition and the Classical Historian," 283.

8. See Greene, "Petrarch and the Humanist Hermeneutic."

9. See Meyer-Kalkus, Wollust und Grausamkeit, for a fascinating discussion of Lohenstein's investigations into human psychological needs. On the "anthropological" interests of the period in general, still see Dilthey, "Die Funktion der Anthropologie."

10. On Lohenstein's theory of political behavior as derived from contemporary political theory, see Mulagk, Phänomene des politischen Menschen im 17. Jahrhundert.

11. The Livy text here is cited after the Gronovius edition (1664-65), 1:97, that I discuss later; English translations follow De Selincourt's Livy, The Early History of Rome, 96 and 92.

12. On the complexities of reproducing Brutus, see Garber, Shakespeare's Ghost Writers, 52-73; Gordon, "Giannotti, Michelangelo, and the Cult of Brutus"; and Hampton, Writing from History, 198-236.

13. On the concept of the "subterranean" presence of an ancient scenario in a modern text, see Greene, "Petrarch and the Humanist Hermeneutic," 206. Lohenstein in fact belonged to the somewhat later period that was fascinated with actual disinterments, as indicated, for example, in Aringhus's Roma Subterranea (1651); on these texts, see Greene, 201-7 and Momigliano, "Ancient History and the Antiquarian," 291.

14. See the entry on Gronovius in the Allgemeine Deutsche Biographie, 9:72123. Lohenstein does not cite which edition of Livy he used; Just also fails to indicate any such edition in his "Register" of sources used in the composition of the plays. Gronovius was nevertheless a contemporary of the Silesian playwright, and his text indicates the kind of edition available to learned politicians such as Lohenstein at the time; it also circulated widely in Europe and contained a huge selection of contemporary annotations. 
15. The notes discussed here appear in Gronovius's Titi Livii Historiarum Quod Extat, 1:96.

16. On Glareanus, see Bietenholz and Deutscher, Contemporaries of Erasmus, $2: 105-8$.

17. On Beatus and his edition of Livy, see John D'Amico, Theory and Practice in Renaissance Textual Criticism, 126.

18. On the similar and similarly pedantic philological squabbling that crowded the annotational margins of many early modern texts, see Grafton, "Renaissance Readers and Ancient Texts."

19. For "history" as an act of textual "reconstruction," see John D'Amico, Theory and Practice in Renaissance Textual Criticism, 206.

20. Spellerberg, "Zur Sophonisbe," nuances claims that the play was tied only to the "brandaktuelles Ereignis" (244) of the marriage with an interpretation of the union's greater geopolitical and ideological significance.

21. Hampton, Writing from History, 205. See also Gordon, "Giannotti, Michelangelo, and the Cult of Brutus."

22. Hampton, Writing from History, 206.

23. See Greene, "Petrarch and the Humanist Hermeneutic," 212.

24. See Ginzburg, "Morelli, Freud, and Sherlock Holmes," 11.

25. On the phenomenon of the Amazons, see Jardine, Still Harping on Daughters, 105, and Jordan, Renaissance Feminism, 224.

26. See Wichert, Literatur, Rhetorik, und Jurisprudenz, 48, on the granting of permissions to produce the plays.

27. On the Szenare, see Spellerberg, "Szenare zu den Breslauer Aufführungen."

28. The Latin Livy text follows Gronovius's of 1664, 2:788. The English Livy here follows De Selincourt, The War with Hannibal, 633.

29. The Latin text is cited after the edition of Boccaccio, De mulieribus claris edited by Vittorio Zaccaria, 280. The English is cited after Guido Guarino's translation, 153.

30. The Latin text here follows Gronovius; the English text follows Moore's edition of Livy, 409. The notes described here may be found in Gronovius's Livy, 2:788.

31. On Sigonius, see McDonald, "Titius Livius," 338.

32. See Gronovius's Livy, 2:791.

33. McDonald, "Titius Livius," describes the Godelevaeus commentary as derivative.

34. See Burke, "A Survey of the Popularity of Ancient Historians," 146-48.

35 . In this connection, it is interesting to note that even "new" and more recent interpretations of Lohenstein's female protagonists by a scholar such as Hubert Fichte in his "Voudoueske Blutbäder," for example, in fact reproduce rather traditional narratives about figures such as Sophonisbe, precisely when they dwell on her erotic nature and alleged predisposition to lust.

36. See Dio's Roman History, 17.57 .53 (p. 224).

37. Although my reading of Lohenstein's Dido figure as crucial to under- 
standing the affirmative side of his Sophonisbe's political profile was complete before I read Hexter's excellent essay on "Sidonian Dido," I am indebted to that article for numerous additional details. The description of Dido as Rome's altera is from Hexter, 338 .

38. On the ambiguity of this surface gesture, see Wichert, Literatur, Rhetorik, und Jurisprudenz, 153.

39. Hexter, 338.

40. See Lord, "Dido as an Example of Chastity."

41. Hexter, "Sidonian Dido," 340.

42. Ibid., 338 .

43. On the history and implications of this countertradition, see Quint, "Voices of Resistance," especially 115 and 120-24.

44. The Latin text follows Fairclough's edition, 1:436-38. The English translation follows Mandelbaum, 4.849-65.

45. See Quint, "Voices of Resistance," 115.

46. See Appian, "The Punic Wars," in White's edition of Appian's Roman History, 5.5.27 (pp. 442-43).

47. See Petrarch, L'Africa, 640, for book 5. Bergin's and Wilson's English translation is cited here.

48. The Latin is cited here after Neri's edition, 490. For the English, see Morley's Tryumphes of Fraunces Petrarcke, 90.

49. The Latin follows Zaccaria's text, 282; the English follows Guarino's edition, 153.

50. Ibid., 284 and 154.

51. On Silius Italicus, see Quint, "Voices of Resistance," 115, and Silius Italicus, Punica: $1.1 .81-139$.

52. On Bernegger's vast philological accomplishments, see Kühlmann, "Geschichte als Gegenwart." On Lohenstein's use of Bernegger's editions, see chapter 3.

53. See Hendreich, Carthago sive Cartheginensium Respublica, 359-60, 1. 383.

54. The Latin follows Zaccaria, 182, and the English follows Guarino, 98.

55. Spellerberg notes Sophonisbe's similarity to Scipio in "Lohensteins Sophonisbe," 381-87, as a "großes Gemüt."

\section{Chapter 2}

1. Massinissa is described as, like most of his African countrymen, congenitally lustful, in Boccaccio's rendering of the Sophonisbe story; see Zaccaria's edition, 282. In its classical intertexts, the Numidian queen is not known as a cross-dresser; in this dimension, it differs from the story of Semiramis, the transvestite Persian queen, who figures in Lohenstein's Agrippina in significant ways. See chapter 3 .

2. Lohenstein's notes indicate that the playwright knew Benedictus Carpzov's Practica rerum criminalium (1635), an early modern handbook that cataloged the rules and regulations of torture in minute detail. Asmuth, Daniel 
Casper von Lohenstein, 5-6, indicates that Lohenstein studied with Carpzov in Leipzig. The specificity of the procedures appears to indicate that Lohenstein was drawing, somewhat anachronistically, on such a tome in his scripting of the several scenes in which Epicharis is tormented. The details are also rendered in the illustration.

3. The obvious exceptions to this generalization were Laura Levine's 1986 essay, "Men in Women's Clothing: Anti-Theatricality and Effeminization from 1579 to $1642, "$ Criticism 28:121-43, which she elaborates in her 1994 book, and Ong, "Latin Language Study."

4. See Burckhardt, Civilization of the Renaissance, 254. I am indebted to a seminar paper by Gina Shaffer (UC Irvine) in the spring of 1997, in which Shaffer investigates the way that gender is handled in Burckhardt and subsequent feminist criticism in a much more in-depth way than has occurred to date.

5. See Kelly, "Did Women Have a Renaissance?" 20 and 19.

6. For a description of the need to resist such "tragic narratives," see Newton and Rosenfelt, "Introduction." Although it is an important book, I would also count Maclean's The Renaissance Notion of Woman as a participant in the production of such a "tragic" story; its inventory of the various deterministic codes of gender in the early modern period paints a picture of inevitable subjection to the rule of "chaste, silent, and obedient." Nevertheless, see Hull's book of this title for a deep sample of texts that did in fact call for such codes.

7. See, for example, Margaret King, Women of the Renaissance, and Wiesner, Working Women, as two powerful introductory books that sought to correct the imbalance in scholarship of the period by focusing not on the constraints that limited women but, rather, on what they did.

8. See Ferguson, "Moderation and Its Discontents."

9. See Migiel and Schiesari, Refiguring Women, 13.

10. Ibid., 14 and 9.

11. Ibid., 7 .

12. See again, of course, Wall's The Imprint of Gender, for a widening of this perspective.

13. For a discussion of women's education and references to work on early modern women's participation in learned culture, which, for the most part, did not take place in the schools, see chapter 3.

14. See Correll, The End of Conduct, 76.

15. See Hippe, "Aus dem Tagebuch," and Spellerberg, "Szenare."

16. On the history of schooling in Breslau, see Eggers, "Das Breslauer Schultheater"; Schlesinger, Geschichte des Breslauer Theaters; Spellerberg, "Das schlesische Barockdrama"; and Wichert, Literatur, Rhetorik, und Jurisprudenz, 47-48.

17. The Breslau Schulordnung (school ordinance) of 1643 is cited in Wichert, Literatur, Rhetorik, und Jurisprudenz, 48. See Wichert, 47-55, on the monitoring of the schools.

18. See Lucae, Schlesiens curieuse Denckwürdigkeiten, 578.

19. See Pliny, Natural History, in the version edited by Rackham, here 5: 168-70. 
20. See Rubin, "The Traffic in Women."

21. See Scott, "Gender: A Useful Category of Historical Analysis," 84 and 92.

22. On Lohenstein's fascination with Rome, see Aikin, The Mission of Rome, 21-26, and Gillespie, Daniel Casper von Lohenstein's Historical Tragedies. Neither comments on the particular interest Lohenstein seems to have had in the more prurient moments of Roman history.

23. On the fascination with gender prodigies, see Greenblatt, "Fiction and Friction"; Montrose, "Shaping Fantasies"; and Dekker and Van de Pol, The Tradition of Female Transvestism.

24. See, for example, Ronzeaud's article, "La femme au pouvoir," on the "upside down world" of women in power, and Maclean, Woman Triumphant.

25. See the Jackson edition of Tacitus, Annals, 4:294-95.

26. See Spellerberg, "Eine unbeachtete Quelle," and Asmuth, Lohenstein und Tacitus, 63-71.

27. See Spellerberg, Verhängnis und Geschichte, 176, and Wichert, Literatur, Rhetorik, und Jurisprudenz, 22-23, on Epicharis's class identity.

28. Asmuth, Lohenstein und Tacitus, 68, mentions Epicharis's Hosenrolle, as does Fichte, "Voudoueske Blutbäder," 148.

29. See Greenblatt, "Fiction and Friction," 92.

30. Gillespie, "Lohenstein's Epicharis," 131, writes of Epicharis's "manly character" as a political virtue.

31. The Latin is quoted after Zaccaria's edition, 374-75, the English after Guarino's edition, 209.

32. On the tradition of women as garrulous, see Jardine, Still Harping on Daughters, 103-40.

33. See Asmuth, Lohenstein und Tacitus, 68.

34. I am indebted for the form of the following reading to a similar passage from Shakespeare's Julius Caesar as it is ably read in Garber, Shakespeare's Ghost Writers, 55-58.

35. On the Frenchman Tiraquellus (André Tiraqueau), see the Biographie universelle ancienne et moderne, 46.

36. See Tiraquellus, De Legibus Connubialibus, 152r-153r.

37. On the background of such references, see Maclean, The Renaissance Notion of Woman, and, more recently, Laqueur, Making Sex.

38. Tiraquellus, De Legibus Connubialibus, 150r-150v.

39. See Rackham's edition of Pliny, 2:562-63.

40. See Rackham's edition of Pliny, 9:180-81. The entirety of the Latin reads: "quam ob rem Athenienses, et honorem habere ei volentes nec tamen scortum celebrasse, animal nominis eius fecere atque, ut intellegeretur causa honoris, in opere linguam addi ab artifice vetuerunt."

41. Pliny, 2:562-63.

42. See Pausanias's Graeciae Descriptio, 1.2.3.1-2.

43. See Tertullian, Apologeticus, 50.8, and Ambrose, De Virginibus, 9.

44. See Tiraquellus, De Legibus Connubialibus, 150 verso.

45. Ibid.

46. See Quilligan, The Allegory of Female Authority, 198 and 204. 
47. On the availability of Pliny editions and on his popularity in the schools, see Cranz and Kristeller, Catalogus Translationum, 4:297-422.

48. See Tristan 1'Hermite, La Morte de Sénèque, V.1747. On the relationship between Lohenstein's and Tristan's plays, see Gillespie, "Lohenstein's Epicharis," 133,141 , and 146-50.

49. The text follows Jackson's edition of Annals, 5:306-7.

50. See Peters, Torture, $11-36$ and $40-73$, here 72 .

51. Ibid., 18-36.

52. See Tacitus in the version edited by Jackson, 5:306-7.

53. On the production of martyr plays, see Gascoigne, Illustrierte Weltgeschichte des Theaters, 72-77. Gascoigne cites Witkowski and Nass, Le nu au Théâtre.

54. On the miracles of the female martyrs and the obsession with their bodies, see Quilligan, The Allegory of Female Authority, 214-21.

55. See Béhar, Silesia Tragica, 1:118. The print is reproduced in volume 3 of Powell's edition of Gryphius's plays as "Abbildung 11." On the planned production of the play, see Zielske, "Andreas Gryphius' Trauerspiel."

56. On the distinction, see Barthes, Empire of Signs, 53.

57. See Just's "Register" in the volume of his edition of Lohenstein's plays that contains the Römische Trauerspiele, 313-14.

58. See Forstner's 1661 notes on Tacitus, 302.

59. Forstner also cites Plutarch's essay on idle chatter, "De Garrulitate" ("Peri Adoleschias"), ibid., 7-8, in which the Pisonian conspiracy is referred to, but with a man rather than Epicharis at the center of the anecdote about holding one's tongue. The intertext is a fascinating one in the context of Lohenstein's play, but since Forstner's note contains no specific reference to a Plutarch edition, he probably knew the source only indirectly via citation elsewhere. The reference is thus of somewhat lesser concern here in my argument about texts that Lohenstein might have actually used.

60. See Ammianus in the version edited by Rolfe, 3:278-81 (= 29.5.53).

61. Ibid., 1:76-77 (= 14.9.3-6).

62. See Valerius in the version edited by Constant, $1: 236-39(=3.3 .2-4)$.

63. See Forstner's 1661 commentary on Tacitus, 294-95.

\section{Chapter 3}

1. See Suetonius in the version edited by Rolfe, 28.228, and Tacitus in the version edited by Jackson, 14.2.

2. See Schlesinger, Geschichte des Breslauer Theaters, 1:6. Wichert, Literatur, Rhetorik, und Jurisprudenz, 47-55, indicates the extent to which both local and imperial authorities were concerned with the social consequences of dramatic productions, especially during the period in which the Protestant schools in Breslau were most active in mounting them, that is, between approximately 1648 and 1670 . See my chapter 2 . Wichert also notes that it is ironic that precisely when Lohenstein himself was named Syndikus in 1670, and thereby ac- 
quired jurisdiction over the city's schools, the productions began to be more heavily monitored (54). Perhaps Lohenstein came to understand the city's hesitations about his plays more profoundly once he became responsible for order in both the town and the schools!

3. Lohenstein addresses Louise as a "kluge Fürstin" in his dedicatory remarks to the play, 12-13. Spellerberg, "Lohensteins Beitrag zum PiastenMausoleum," 681, suggests that the inscription on Louise's coffin, described by Lucae, in which she is called a "Preißwürdigste Regentin," may have been authored by Lohenstein. Duke Christian's will is quoted in Schück, "Drei schlesische Fürstenfrauen," 89 (my translation). Dr. Ewa Pietrzak (Wroclaw) was kind enough to forward a copy of Schück's article to me. Louise's background, education, marriage, widowhood, and regency are described in detail in Lucae, Schlesiens curieuse Denckwürdigkeiten, 1501-40.

4. Lohenstein himself characterizes the play as "lasterhaft" (lecherous). See his prefatory remarks to the notes in Agrippina, 113, 1. 2. His acknowledgment of the apparently questionable moral niveau of the text makes the fact of its dedication to the duchess all the more puzzling.

5. Lucae, Schlesiens curieuse Denckwürdigkeiten, chap. 10, "Von dem Briegischen Fürstenthum" (On the Principality of Brieg) sketches the story of the Piastian house during these years. See also Sinapius, Des Schlesischen Adels Anderer Theil, 139-40, on Louise's succession to the regency. Schöffler, Deutscher Osten, describes the network of Calvinist princes and sympathizers during this period; see Wichert, Literatur, Rhetorik, und Jurisprudenz, 150-51, on the "conciliatory" politics of the Piastian princes, and 105-6, on Duchess Louise and the death of George William.

6. On the Salic Law, see Ronzeaud, "La femme au pouvoir," and Maclean, Woman Triumphant, 1-24, especially 16. Also see Maclean, The Renaissance Notion of Woman, 73-75. For a central European rendering of the Salic Law debate and of its applicability in the face of a break in a dynastic line, see Goclerius, Foemina Illustris, especially "Caput Decimum," 31-33, on the issue of mothers succeeding to positions as heads of state. Petry and Menzel, Geschichte Schlesiens, 2:81, note that there was even a brief moment in Silesian history in the 1660s when the suggestion was made that the laws of succession be amended to include daughters because of the failure of the males of all the branches of the line to produce surviving sons.

7. See Lohenstein, Lob-Schrifft, C3.

8. On Oels as "ein weibliches Lehngut" and on Elizabeth Maria's regency ("Ober-Vormundschafft") for her sons, see Lucae, Schlesiens curieuse Denckwürdigkeiten, 1133-39. Grünhagen, Geschichte Schlesiens, 351-52, neglects to note Elizabeth Maria's regency.

9. On Lohenstein's employment by these female regents, see Gebauer's foreword to his edition of Lohenstein's Großmüthiger Feldherr Arminius (1731), 1:viii. Also see Sinapius, Olsnographia, 1:647-48 and 679-80; Sinapius, Des Schlesischen Adels Anderer Theil, 787; and Müller, Beiträge, 42-45.

10. On Lohenstein's activities as Syndikus and on the trip to Vienna, see Müller, Beiträge, 45-61, and Wichert, Literatur, Rhetorik, und Jurisprudenz, 145-48. 
11. See Kühlmann, "Geschichte als Gegenwart," and Jed, Chaste Thinking, 18-50.

12. See Etter, Tacitus in der Geistesgeschichte, 159, n. 285. On Queen Christina in general, see Friese, "Christina," who represents Christina's familarity with the historiographial tradition as a result of her "männliche Erziehung" (masculine education) (479).

13. See Schurmann's letters in her Opuscula; the 1639 letter to Elizabeth of Bohemia is cited on 207-8.

14. See Schurmann's treatise on education for women, Num foeminae christianae conveniat studium litterarum?. Excerpts are available in Gössmann, Das Wohlgelahrte Frauenzimmer, 47-52. On Schurmann, see Becker-Cantarino, "Die 'gelehrte Frau.'"

15. See the collection of learned women's lives by Frawenlob, Die Lobwürdige Gesellschaft Der Gelehrten Weiber (1631-33), reprinted in Gössmann, Eva: Gottes Meisterwerk, 46-83. The reference to the reading of histories may be found in his life of the young Anna Maria Kramerim (d. 1627), 55-56. Frawenlob describes Louisa Amona of Anhalt (as well as countless others) as "in der Lateinischen und Frantzösischen Sprache gelehrt" (learned in Latin and French) (72). On this tradition of collections of stories of legendary, historical, and contemporary women in central Europe, see Woods, "Das 'Gelahrte Frauenzimmer.'"

16. On the schooling of young noblewomen of the period, see Kleinschmidt, "Gelehrete Frauenbildung," 549--57. Becker-Cantarino, "Die 'gelehrte Frau,'" 562 , underscores that this was the custom only among the elite, but Davis, "Gender and Genre," 157, sees the participation of learned noblewomen in the historiographical tradition as symptomatic of their "strong connection or concern with the politics of their time." On education as "vocational training" of noblewomen, see Grafton and Jardine, From Humanism to the Humanities, 29-57, "Women Humanists: Education for What?"

17. See Le Moyne, Galerie, 10. For several conflicting readings of Le Moyne's stance on the issue of education and power for women, see Maclean, Woman Triumphant, 77-79 and 188, and Lougee, Le paradis des femmes, 63-64. More recently, see Schlumbohm, "Die Glorifizierung der Barockfürstin."

18. Torquato Tasso's treatise on women, Discorso della virtu feminile e donnesca (1582), seems to have been one of the "master texts" of this discussion. See Maclean, Woman Triumphant, 19-21. Le Moyne may refute Tasso in his Galerie (191-96), but his examples, especially of Semiramis, indicate more of a shared set of assumptions than he lets on.

19. See, for example, Lunding, Das schlesische Kunstdrama, 126-35, and Stachel as cited in Just, Die Trauerspiele Lohensteins, 121. Asmuth, Lohenstein und Tacitus, 26-27, sees the effect of the incest scene as "rhetorical," which causes him to miss the additional levels of complexity that would have been suggested by the performance.

20. See Spellerberg, "Szenare," 636-39, on the pamphlet summaries (Szenare) handed out at the time of the play's production.

21. See Tacitus, 14.2 , in the version edited by Jackson, $5: 108-9$. I am indebted in what follows to Wichert's analysis of the question of Agrippina's culpability in Literatur, Rhetorik, und Jurisprudenz, 383-86. 
22. See Just's introduction to his 1955 edition of Lohenstein's Römische Trauerspiele, xiv.

23. See Guillemin's edition of Nepos, 4-5.

24. There were some sixteen editions of Nepos published between the time of the editio princeps in 1470 and 1675, five of which were written by northern European humanists between 1608 and 1657, approximately the dates of editions to which Lohenstein would have had easy access. See Marshall's foreword to his edition of Nepos, $x-x i$.

25. In what follows, I refer to the 1734 Nepos edited by Van Staveren, 6-7, unless otherwise indicated.

26. See the article on Ernestius in Jöcher, Allgemeines Gelehrten-Lexikon, 2:385. Marshall dates Ernestius's Nepos edition as having been published in 1637. See his edition of Nepos, $x i$.

27. On the Frenchman Brisson, see Jöcher, Allgemeines Gelehrten-Lexikon, 1:1385-86. On Gronov/Haverkampius, see ibid., 2:1193.

28. See Zaccaria's edition of Boccaccio, 32-39, and Guarino's edition, 4-7.

29. On Kircher's vast influence on poets of the period, see Fletcher, Athanasius Kircher.

30. See Diodorus of Sicily, Bibliothekes Istorikes, 2:4-20 (pp. 356-417 of Oldfather edition). In what follows, the book, chapter numbers, and lines are cited parenthetically in the text.

31. It must have been a reading of Diodorus's version of the Semiramis story that gave Christine de Pizan the impetus to represent her Semiramis as a politically astute woman, whose act of incest with her son is explained as a protective measure against potential encroachment upon her power and as an indication of her political self-assurance, for no other man was worthy of her. See de Pizan, Book of the City of Ladies, 38-40. On Christine's Semiramis, see Quilligan, The Allegory of Female Authority, 69-84. Quilligan does not mention the Diodorus source.

32. See Herodotus, Historien, 168-69; Plutarch, "Mulierum Virtutes," 3 : 476-77, "Regum et Imperatorum Apophthegmata," 3:14-15, and "Amatorius," 9:332-35, all in Moralia; and Aelianus, Sophistae Variae Historia, 204-7.

33. See Seel's edition of Justinus, 1.1.10-2.13 and 4-5.

34. See Samuel, "Semiramis in the Middle Ages," 34-35; Augustine, The City of God, 5:370-73; and Orosius, Histoire contre les Païens, 1.4.1-8 and 43-45.

35. See Bernegger's edition of Justinus, 5.

36. See Lohenstein's Sophonisbe, 396, 11. 163-64 and 404, 11. 533-36, where he refers explicitly to Bernegger's commentary on Justinus.

37. Ibid., 7 .

38. On the medieval method of the mos italicus and its afterlife in Renaissance jurisprudence, see Maclean, The Renaissance Notion of Woman, 68-69.

39. See Bernegger's edition of Justinus, 269-70.

40. See, for example, the edition of Justinus printed in Breslau in 1660, 8-12.

41. The final scene of Lohenstein's Agrippina can be read as an inversion of the end of book 4 of the Aeneid, where Dido uses the talents of a sorceress to invoke Aeneas's spirit. Lohenstein in fact alludes to the Aeneid in his notes 
$(132,1.172 ; 134,11.255-58 ;$ and 135, 11. 296-99). If Nero plays Dido to Agrippina, his Aeneas, in Lohenstein's play, then the murdered queen mother is associated with a figure, namely, Aeneas, conventionally coded as a political "hero." That Agrippina's spirit is allowed to "haunt" Nero here also associates her with the unjustly wronged figures of contemporary tyrant dramas; see Bushnell, Tragedies of Tyrants. Menhennet, "The Death of Lohenstein's Agrippina," analyzes the positive valences of the queen's character at the end of the play but does not look to Lohenstein's sources; Béhar, Silesia Tragica, 1:100102 , has analyzed the scene's references to demonological texts of the period.

42. See the van Staveren edition of Nepos, 11-12.

43. On Boecler in particular, see Etter, Tacitus in der Geistesgeschichte, 160-61. Kühlmann, "Geschichte als Gegenwart," also discusses the background and significance of this group.

44. Cited in Kühlmann, "Geschichte als Gegenwart," 342, n. 30.

45. On Forstner, see Etter, Tacitus in der Geistesgeschichte, 162-66, and Stein, "Christoph Forstner." Forstner's Notae Politicae on Tacitus's Annals were published over a number of years. The volume on the first six books was written and published in Padua in 1626, when Forstner was a young student; the second volume (1631) was dedicated to the imperial chancellor, Peter Heinrich of Stralendorf, through whom Forstner hoped to secure a position at the court in Vienna. The commentaries on the later books were written and published in 1652 and 1661, after Forstner had witnessed firsthand the intricacies of political behavior and court intrigue from Paris to Uppsala to Vienna, when he was chancellor of the earldom of Montpelier. The 1652 volume was in fact dedicated to Queen Christina of Sweden, presumably because of the famous similitudo temporis between the days of the Roman Principate and those of her own rule. The parallels between both of these situations and late-seventeenth-century Liegnitz may not have been lost either on Lohenstein or on Duchess Louise. See Stein, 64-71.

46. Citations to Tacitus in the following discussion are to book, chapter, and page of the Annals, cited after Jackson's edition. Forstner clearly meant his notes to be read alongside an edition of Tacitus; thus his text does not contain the entire text of Tacitus, but rather just the ends of the lines on which he comments, as a way for readers to orient themselves in his notes. Forstner's Tacitus commentaries are cited according to date, hence, for example, Tacitus (1652) refers to Forstner's volume containing commentary on books 11, 12, and 13 of the Annals, published in Leiden in 1652.

\section{Chapter 4}

1. I confine the term "race" in quotes here so as to indicate the necessity for defining it more exactly in terms of early modern values. The quotes drop away at the end of this section once my definitions have been laid out.

2. See Plutarch, "Life of Antonius," 452-53, and Dio Cassius, Dio's Roman History, 51.15.6 (pp. 42-43) and 54.5.4-6 (pp. 292-93). 
3. The first printed edition of Lohenstein's Cleopatra appeared in 1661, the year of its original production; the second expanded edition was published in 1680, also with additional notes. On the production history of the play, see Asmuth, Daniel Casper von Lohenstein, 27. For analyses of the changes in the second edition, see Béhar, Silesia Tragica, 2:69-79 and 119-30; Juretzka, Zur Dramatik Daniel Caspers von Lohenstein, especially 217-19; and Müller, Beiträge zum Leben und Dichten Daniel Caspers von Lohenstein, 64-107.

4. The most prominent of these is Athanasius Kircher, whose Oedipus Aegypticus (1652), a massive introduction to Egyptian lore, Lohenstein also cites repeatedly in the notes to Cleopatra. See Müller, Beiträge zum Leben und Dichten, $76-77$, for a list of the numerous encyclopedic tomes and travelogues that Lohenstein cites.

5. See Just, Die Trauerspiele Lohensteins, 155.

6. See Hall, "Masque of Blackness," 10, and, more recently, Things of Darkness, and Hendricks, "Managing," especially 166.

7. See Wansleben, Nouvelle Relation, 41-43. Unless otherwise noted, the following discussion refers to these pages.

8. Debrunner, Presence and Prestige, 56, refers to this trip. Also see Jöcher, Allgemeines Gelehrten-Lexikon, 4:1812-13.

9. See Ludolf, Commentarius, 35, on the drowning, as well as Jöcher, Allgemeines Gelehrten Lexikon, $4: 1812$.

10. See Debrunner, Presence and Prestige, 54, and Jöcher, Allgemeines Gelehrten Lexikon, 2:2574-75.

11. On these theories of religion, see Debrunner, Presence and Prestige, 53, and Roelofsen, "Grotius and the International Politics," 130. In an English-language text printed in London in 1678 and attributed, ironically, to Wansleben, the story of the baptism of the first Ethiopian Christian and of the subsequent spread of Christianity throughout Ethiopia is recounted. See A Brief Account, 2.

12. Ludolf writes of the relationship of the Ethiopian tongue to Chaldean in his Historia Aethiopica, 9. See also Borst, Der Turmbau von Babel, 1474-75.

13. Ludolf narrates the story of his acquaintance with Gregory in his Commentarius, 28-35. On the ongoing interest of European Christianity in investigating, indeed even supporting its ancient African relative, see Barthelemy, Black Face, Maligned Race, 15, n. 27. On Grotius, see Debrunner, Presence and Prestige, 53.

14. See Ludolf, A New History, 19, and Uhlig, Hiob Ludolfs "Theologia Aethiopica."

15. See Ludolf's address to the reader, A New History, unpaginated.

16. See Debrunner, Presence and Prestige, 55.

17. Ludolf, A New History, 317-70.

18. Ibid., "Address to the Courteous Reader," unpaginated.

19. Ibid., 203 and 205.

20. Ibid., 5 .

21. Ibid., 32 .

22. Ibid., 71 .

23. Ibid., 191.

24. Ibid., 71-74. 
25. See Harding, The "Racial" Economy of Science, 8-9.

26. Riffaterre, "Interview," 16, argues that "textual ungrammaticalities are but the other face of intertextual grammaticalities." Following Riffaterre, I would argue that what might appear to be breaks in logic in the representation of Cleopatra in Lohenstein's play become legible as a way of maintaining an intertextual or discursive logic rooted in understandings of race such as those indexed in Wansleben's and Ludolf's texts.

27. Asmuth, Lohenstein und Tacitus, 181, suggests that Lohenstein was influenced in his development of the Caesarion scene by the French novel Cléopatre (1647-48) by Gautier de Costes de La Calprenede, in which Caesarion and Candace become lovers, but no such development is alluded to in Lohenstein's play.

28. On the tradition of African women calling down doom upon Rome, see Quint, "Voices of Resistance," and my chapter 1 on Dido and Sophonisbe. Quint notes that it is the male African, Hannibal, who is assigned the position of curser in Silius Italicus's Punic Wars; Lohenstein's Cleopatra would thus have her "Roman" son mimic the African male that she would have him be here. This intertextual "darkening" would mirror the need for makeup in this scene, had it been staged. As indicated earlier, no more plays were produced in Breslau after 1671.

29. See Barthelemy, Black Face, Maligned Race, 7.

30. See Boose, "'The Getting of a Lawful Race,'" 43-46, and Hendricks, "Managing," 181.

31. Regardless of how European in extraction the historical Cleopatra was (see Hughes-Hallett, Cleopatra, 15), Lohenstein's Cleopatra is referred to repeatedly as "dark."

32. See Hendricks, "Managing," 180-81, for a fascinating discussion of the dangers of tolerating a Roman-sired son born of an African queen in Marlowe's Tragedy of Dido.

33. Reinhold, From Republic to Principate, 12-14.

34. Spellerberg, Verhängnis und Geschichte, 51 and 151, for example, and Juretzka, Zur Dramatik Daniel Caspers von Lohenstein, 150-53, have noted Cleopatra's essentially political profile in Lohenstein's version, as opposed to Just, Die Trauerspiele Lohensteins, 163, for whom she is merely an erotic distraction in an essentially male-identified political world.

35. Mention is also made of German allies (41, 11. 607-9). This scene may be based on Dio 51.3, which Lohenstein cites in the note to line 603 .

36. There is thus something of an "antiepic" and hence anti-Roman quality to Lohenstein's Cleopatra, as there is to his Sophonisbe. For a delineation of conventional "epic" qualities, see Quint, "Epic and Empire," 1-12, particularly on the place of the Cleopatra legend in association with an antiepic stance in Virgil's Aeneid.

37. On the "tawniness" of Shakespeare's Cleopatra, see Boose, "The Getting of a Lawful Race,," 47-48.

38. See Asmuth, Daniel Casper von Lohenstein, 28-30, and Juretzka, Zur Dramatik Daniel Caspers von Lohenstein, 34-35.

39. Béhar, Silesia Tragica, 1:129-33, has compared the two plays in depth, 
but primarily in terms of their respective relationships to the classical historiographical sources.

40. The terms are Béhar's. See ibid., 1:132.

41. On this tradition, see Hughes-Hallett, Cleopatra, 113-31, and Juretzka, Zur Dramatik Daniel Caspers von Lohenstein, 32-33.

42. See Jack D'Amico, The Moor in English Renaissance Drama, 71-72.

43. On the distinction between the "body natural" and the "body politic" of the woman in Renaissance drama, see Jankowski, Women in Power, 54-76. Jankowski analyzes the tension between the two as it appears in Shakespeare's Antony and Cleopatra (151-63), but does not address an essential dimension of that female body, namely complexion.

44. On the use of the blazon to control Woman, see Vickers, "The Blazon of Sweet Beauty's Best" " and "Diana Described," as well as Parker, "Rhetorics of Property." The quotations here are from Vickers, "'The Blazon,'” 96, and "Diana Described," 95, and Parker, "Rhetorics," 131, respectively.

45. Little, "'An Essence That's Not Seen,'" has argued that Shakespeare's Cleopatra is gradually "whitened" as a result of her increasingly nonthreatening status. The Petrarchistic language of Lohenstein's play would initially seem to have the same effect.

46. On the effects of inverting or frustrating the silencing of the blazoned woman that the tropes of the figure conventionally enact, see Jones, "Assimilation with a Difference," 136.

47. Gillespie, Daniel Casper von Lohenstein's Historical Tragedies, 100, sees Lohenstein's Antonius as succumbing to an "Egyptian attachment" here, but again, describes this attachment as primarily erotic rather than strategically political.

48. The malleability of the term "Moor" in the period might suggest that simply because she is so designated does not necessitate that Lohenstein's Cleopatra be dark. She is, however, described as Antonius's "braunes Ehweib" (brown wife) $(73,1.531)$ later in the play. Since Cleopatra has already appeared on stage by this time, her complexion would have already been in evidence in 1661 before the blazoning scene analyzed here. Both Mairet and Shakespeare, of course, have Octavia appear on stage, thus providing the potential for a heightened contrast between the Egyptian and the Roman woman. Lohenstein's Octavia appears only as a verbal icon of fairness.

49. See Charlesworth, "The Fear of the Orient," 13-15.

50. See Plutarch's Lives in Spevack's edition, 439.

51. See Dittenberger's early-twentieth-century edition of the inscriptions in his Orientis Graeci Inscriptiones Selectae. At least until the beginning of this century, then, the inscriptions were taken as fact.

52. Hughes-Hallett, Cleopatra, 70-110, outlines the other way in which Cleopatra had been associated with a vast, oppositional power, namely, the Hellenic-Arabic, eastern Asian connection. Quint, "Epic and Empire," also emphasizes Cleopatra's association with an "eastern" (rather than specifically African) profile.

53. See Hughes-Hallett, Cleopatra, 108. 
54. See the Relations de divers Voyages Curieux, vij.

55. Ibid., 21.

56. On the relationship between these varieties of history, see Shapiro, "History and Natural History," as well as Newman, "Citational Science," with bibliography there.

57. See Béhar, Silesia Tragica, 1:134-39.

58. Spon's text was subsequently translated into German and published in Nuremberg in 1690. Lohenstein clearly used the French version in his 1680 Cleopatra revisions.

59. See Spon, Voyage d'Italie, 61.

60. Lohenstein cites "le Journal des Scavans" in his notes on 157-58, 11. 20818 (a citation that is directly followed by a reference to Wansleben) and on 199, 11. 342-44. On his reading of the Journal, see Newman, "Citational Science."

\section{Conclusion}

1. In the formulation and project of looking for the ways in which texts and figures move into their "afterlives," I am much indebted to the work of Lupton in Afterlives of the Saints.

2. The characterization of the texts of the Baroque as "entlegnen" occurs in a letter that Benjamin directed to Franz Schultz, the director of the thesis. This and the other letters discussed here may be found in volume I-3 of Tiedemann's and Schweppenhäuser's edition of Benjamin's works, 873-78. Here 873.

3. Some scholars have noted individual references to secondary literature in Benjamin's notes. See, for example, Wolin, Walter Benjamin, xxix-xxxiii, BuciGlucksmann, La raison baroque, 65 and 71, and Lupton, Afterlives of the Saints, 33. Steiner investigates Benjamin's notes and their impact upon the text in some detail. See his "Allegorie und Allergie." Yet little attention has been paid to the work of his contemporaries in the field of Baroque studies that Benjamin appears to have known or to the plays themselves as they function in Benjamin's book. Garber's work is an exception here.

4. See Steiner, "Allegorie und Allergie," 645-47.

5. Steiner, ibid., is very useful for this question; I am pursuing the question of Benjamin, the Baroque, and philology in a separate project. For some exceedingly stimulating ideas about how to understand Benjamin's method in the Trauerspiel book, I am indebted to a seminar paper, "Melancholic History," by Francie Crebs (UC Irvine) written in conjunction with a reading course on Benjamin's sources in the Trauerspiel book in 1998.

6. See Trunz, "Erinnerungen an Julius Petersens Seminar 'Deutsche Barocklyrik' im Winter 1927/28 an der Universität Berlin," and Boden, "Julius Petersen."

7. Many years later, Richard Alewyn, who was intimately involved as one of the rising young stars of Baroque studies in the early part of the century, refers to these years as "eine der bewegtesten Epochen der deutschen Geistesgeschichte" (one of the most exciting periods of German Geistesgeschichte), in 
which "Philologie," formerly leading a mundane existence "unter der Obhut der Sprachwissenschaft" (under the protection of linguistic studies), became a tumultuous academic scene. Seventeenth-century literature was considered a "Neuland" (new world) that could be and was "mapped" by these earlytwentieth-century academic explorers. See Alewyn, Vorwort, 9, and my subsequent discussion.

8. The story of the ultimate rejection by Schultz of Benjamin's thesis has been told very often. The commentary volume of the Tiedemann and Schweppenhäuser edition, I-3, summarizes the events, 895-902.

9. See Benjamin, "Eduard Fuchs, Der Sammler und der Historiker," volume II-2, 467.

10. See Newman, "Baroque Legacies."

11. See Greetham, "The Manifestation and Accommodation of Theory in Textual Editing"; McGann, "Literary Pragmatics and the Editorial Horizon"; and Tanselle, Textual Criticism and Scholarly Editing. Also see Bornstein and Williams's excellent collection, Palimpsest: Editorial Theory in the Humanities.

12. See Greetham, "Editorial and Critical Theory: From Modernism to Postmodernism," 18.

13. For a more in-depth discussion of Just's editorial work and of Gerhard Spellerberg's "response" to it in the new edition of Lohenstein's work planned and begun before Spellerberg's untimely death in 1996, see Newman, "Textual Reproduction and the Politics of the Edition."

14. The following is based on Fechner's brief "In memoriam" on Just as well as on letters and documents found in the Nachlaß of Hermann Schneider in the Universitätsarchiv (Tübingen) and in the Nachlaß of Josef Breitbach in the Deutsches Literaturarchiv (Marbach). Personal communication with Fechner (Bochum) and Hugh Powell (Indiana) during 1995-96 also helped me enormously.

15. See Zentner and Bedürftig, The Encyclopedia of the Third Reich, 481.

16. For an in-depth series of articles on the post-1945 reaction of German literary studies to the war and its aftermath, see the excellent collection edited by Barner and König, Zeitenwechsel.

17. See Just's essay in the volume of the Türkische Trauerspiele, 91, n. 2.

18. Ibid., VIII.

19. Ibid., VII.

20. This letter may be found in the Schneider Nachlaß in the Tübingen Universitätsarchiv. See text.

21. See Barner, "Zwischen Gravitation und Opposition. Philologie in der Epoche der Geistesgeschichte," especially 208-9.

22. For the foreword to the Festschrift for Schneider, see Festschrift Paul Kluckhohn und Hermann Schneider.

23. Again, these documents may be found in the Hermann Schneider Nachlaß in the Universitätsarchiv in Tübingen.

24. In a telephone interview with the present general editor at Hiersemann, Dr. Dornemann, on September 5, 1996, I learned that the press also appears to have no records of the financial transactions of these years. 
25. Personal communication from Professor Jörg-Ulrich Fechner, Just's colleague during the 1960s and 1970s, October 31, 1995.

26. See Just, "Lohenstein und seine Welt," 239.

27. See Just, "Neue Schlesische Barockliteratur. Marian Szyrocki/Martin Opitz-Der junge Gryphius," 52.

28. See Moeller, "War Stories," 1021-34.

29. See Schlesien 6 (1961), 11.

30. See Newman, "(Post) Cold War Renaissance Studies."

31. Personal communication from Professor Jörg-Ulrich Fechner, October 31, 1995.

32. See Biddick, "Bede's Blush," 24.

33. See Czaplicka, Huyssen, and Rabinbach, "Introduction," 10-11.

34. See Fleming and Bailyn, The Intellectual Migration: Europe and America, 1930-1960.

35. See Berman, "Three Comments," 116-17.

36. See Lawrence Levine, The Opening of the American Mind, 54-74.

37. See Berman, "Three Comments," 117.

38. See König, "Eine Rekonstrucktion," 1.

39. See Kiesant, "Die Wiederentdeckung der Barockliteratur," 78.

40. Ibid., 82.

41. See Strich, Deutsche Klassik, for example.

42. Hermand, Geschichte der Germanistik, 98-113.

43. Bermann, "Three Comments," 115.

44. Ibid., 124, and Appiah, "Geist Stories," 52.

45. For the fascinating history of this East-West divide that extends back into the eighteenth century at least, see Wolff, Inventing Eastern Europe. 



\section{Bibliography}

\section{Primary Sources}

Aelianus. Cl. Aeliani Sophistae Variae Historiae Libri XIV. Basel, 1774.

Ambrose. S. Ambrosii Mediolanensis Episcopi De Virginibus Libri Tres. Edited by Egnatius Cazzaniga. Turin: G. B. Paravia, 1948.

Ammianus Marcellinus. Ammiani Marcellini Rerum Gestarum Qui de XXXI. Supersunt Libri XVIII. Ad fidem Ms. E veterum Codd. recensit Observationibus illustrati. Ex Bibliotheca Fr. Lindenbrogi. Hamburg, 1609.

- Ammiani Marcellini Rerum Gestarum Qui de XXXI. Supersunt Libri XVIII. Ex Ms. Codicibus emendati ab Henrico Valesio, E Annotationibus illustrati. Paris, 1636.

- Rerum Gestarum Libri qui Supersunt. Edited and translated by John C. Rolfe. 3 vols. London: W. Heinemann, 1956.

Appianus of Alexandria. Appian's Roman History. Edited by Horace White. 4 vols. Cambridge: Harvard University Press, 1912.

Augustine. The City of God against the Pagans. Edited by Eva Matthews Sanford and William McAllen Green. 7 vols. Cambridge: Harvard University Press, 1965.

Benserade, Isaac de. La Cléopâtre de Bensseradde. Tragédie. Paris, 1636.

Boccaccio, Giovanni. Concerning Famous Women. Translated by Guido A. Guarino. New Brunswick: Rutgers University Press, 1963.

- De mulieribus claris. Vol. 10 of Tutte le opere di Giovanni Boccaccio. Edited by Vittorio Zaccaria. Verona: Mondadori, 1967.

de Pizan, Christine. The Book of the City of Ladies. Translated by Earl Jeffrey Richards. New York: Persea, 1982.

Dio Cassius Cocceianus. Dio's Roman History. Edited and translated by Earnest Cary. 9 vols. London: Heinemann; Cambridge: Harvard University Press, 1955.

Diodorus of Sicily. Bibliothekes Istorikes. Edited by C. H. Oldfather. 10 vols. London: Heinemann, 1946.

Dittenberger, Wilhelm. Orientis Graeci Inscriptiones Selectae. Leipzig, 1903-5. Reprint, Hildesheim: G. Olms, 1986.

Golcerius, Franciscus. Foemina Illustris. N.p., 1687.

Gryphius, Andreas. Trauerspiele. Edited by Hugh Powell and Marian Szyrocki. 8 vols. Tübingen: Niemeyer, 1963-72.

Hendreich, Christophorus. Carthago sive Cartheginensium Respublica, Quam Ex totius fere antiquitatis ruderibus Primus Instaurare Conatur. Amsterdam, 1664. l'Hermite, Tristan. La Morte de Sénèque (1644). In Le théâtre complet, edited by Claude K. Abraham et al., 217-326. Tuscaloosa: University of Alabama Press, 1975. 


\section{Bibliography}

Herodotus. Historien. Edited by Josef Feix. Munich: Ernst Heimeran, 1963. Justinus. Justini in Historias Trogi Pompeii Epitomarum Editio Nova, Accurante Matthia Berenccero. Straßburg, 1631.

- Justinus Philippische Geschichte. Edited and translated by Christian Schwarz. Stuttgart: Metzler, 1838.

—. M. Juniani Justini Epitoma Historiarum Philippicarum Pompei Trogi. Edited by Otto Seel. Stuttgart: Teubner, 1972.

- Trogus Justinus cum notis selectissimis Variorum Berneggeri Bongarisii, Vosii, Thysii, Ec. Editio accuratissima. Breslau, 1660.

Kircher, Athanasius. Oedipus Aegypticus. Hoc est Universalis Hieroglyphicae Veterum Doctrinae temporum iniuria absoluta Instauratio. Rome, 1652.

Le Moyne, Pierre. La Galerie des Femmes Fortes. 1647. Reprint, Paris, 1660.

Livy. Ab Urbe Condita. Edited by Frank Gardner Moore. 14 vols. Cambridge: Harvard University Press, 1949.

_ . The Early History of Rome. Translated by Aubrey De Selincourt. Harmondsworth: Penguin Books, 1961.

. Titi Livii Historiarum Quod Extat, Cum perpetuis Gronovii et Variorum notis. 2 vols. Amsterdam, 1664-65.

. Titus Livius/Unnd Lucius Florus von Ankunfft und Ursprung des Römischen Reichs/der alten Roemer herkommen/Sitten/Weissenheit/Ehrbarkeit/ löblichen Regimen/Ritterlichen Thaten/Victori und Sieg/gegen ihre Feinden. . . . Straßburg, 1619.

The War with Hannibal. Translated by Aubrey De Selincourt. Harmondsworth: Penguin Books, 1965.

Lohenstein, Daniel Casper von. Afrikanische Trauerspiele. Edited by Klaus Günther Just. Stuttgart: Hiersemann, 1957.

- Dem Weyland Durchlauchtigen Fürsten und Herrn, Herrn George Wilhelms, Hertzogens in Schlesien, zu Liegnitz, Brieg, und Wohlau, Christ-mildesten Andenckens, Durch Daniel Caspers von Lohenstein, auf Kittlau, Reisau und Roskowitz, der. Röm. Kays. Stadt Bresslau Syndicum, gefertigte Lob-Schrifft. Breslau and Leipzig, 1679.

. Großmüthiger Feldherr Arminius oder Hermann ... Andere durch und durch verbesserte und vermehrte Auflage. Leipzig: Johann Friedrich Gleditschens sel. Sohn, 1731.

—. Römische Trauerspiele. Edited by Klaus Günther Just. Stuttgart: Hiersemann, 1955.

—. Türkische Trauerspiele. Edited by Klaus Günther Just. Stuttgart: Hiersemann, 1953.

Lucae, Friedrich. Schlesiens curieuse Denckwürdigkeiten, oder vollkommene Chronica Von Ober- und Nieder-Schlesien. Frankfurt, 1689.

Ludolph, Hiob. Ad Suam Historiam Aethiopicam Ante Hac Editam Commentarius. Frankfurt, 1691.

- Grammatica Aethiopica. London, 1661.

- Historia Aethiopica. Sive brevis \& succincta descriptio Regni Habessinorum. Quod vulgo male Presbyteri Iohannis vocatur. Frankfurt, 1681.

- Lexicon Aethiopico-Latinum. London, 1661. 
- A New History of Ethiopia. Being a Full and Accurate Description of the Kingdom of Abessinia, Vulgarly, though Erroneously, called the Empire of Prester John. In Four Books. By the Learned Job Ludolphus, Author of the Ethiopic Lexicon. Made English, by J. P. Gent. London, 1682.

Machiavelli, Niccolo. Discourses on the First Decade of Titus Livius. Vol. 1 of Machiavelli, The Chief Works and Others. Translated by Allan Gilbert. Durham: Duke University Press, 1989.

Nepos, Cornelius. Cornelii Nepotis Vitae Excellentium Imperatorum, Cum integris Notis Jani Gebhardi, Henr. Ernestii, E Jo. Andrea Bosii, Et Selectis . . Augustino van Staveren, qui \& suas notas addidit. Leiden, 1734.

—. Cornelii Nepotis Vitae cum Fragmentis. Edited by Peter K. Marshall. Leipzig: Teubner, 1977.

- Oeuvres. Edited and translated by Anne-Marie Guillemin. Paris: Société d'Édition "Les Belles Lettres," 1961.

Orosius. Histoire contre les Païens. Edited by Marie-Pierre Arnaud-Lindet. Paris: Les Belles Lettres, 1990.

Pausanius. Description of Greece. Translated by J. G. Frazer. 6 vols. New York: Biblo and Tannen, 1965.

- Graeciae Descriptio. Edited by Maria Helena Rocha-Pereira. 3 vols. Leipzig: Teubner, 1973.

Petrarch, Francesco. L'Africa. Edited by Nicola Festa. Florence: G. C. Sansoni, 1926.

- Africa. Edited by Thomas G. Bergin and Alice S. Wilson. New Haven: Yale University Press, 1977.

_ Rime-Trionfi-e Poesie Latine. Edited by F. Neri et al. Milan: R. Ricciardi, 1951.

- Tryumphes of Fraunces Petrarcke. The First English Translation of the 'Trionfi' by Lord Morley. Edited by D. D. Carnicelli. Cambridge: Harvard University Press, 1971.

Pliny the Elder. Natural History. Edited by H. Rackham. 10 vols. Cambridge: Harvard University Press, 1950.

Plutarch. "The Life of Marcus Antonius." Thomas North's translation of Plutarks Lyves (1579). In A New Variorum Edition of Shakespeare Antony and Cleopatra, edited by Martin Spevack, 395-456. New York: MLA, 1990.

- Moralia. Edited and translated by Frank Cole Babbitt. 14 vols. London: Heinemann, 1949.

Relations de divers Voyages Curieux, Qui N'ont Point Esté Publiées ou Qui ont esté Traduites d'Hacluyt, de Purchas, E d'autres Voyageurs Anglois, Hollandois, Portugais, Allemands, Espagnols, Et de Quelques Persans, Arabes, et Autres Auteurs Orientaux. Part 1. Paris, 1663.

Schurmann, Anna Maria van. Opuscula (1648). Edited by Friedrich Spanheim. Leipzig, 1749.

Silius Italicus. Punica. Edited and translated by J. D. Duff. 2 vols. Cambridge: Harvard University Press, 1927.

Sinapius, Johannes. Olsnographia, oder Eigentliche Beschreibung Des Oelßnischen Fürstenthums In Nieder-Schlesien. 2 vols. Leipzig and Frankfurt, 1707. 
. Des Schlesischen Adels Anderer Theil, Oder Fortsetzung Schlesischer Curiositäten. Leipzig and Breslau: Rohrlach, 1728.

Spon, Jacob. Italiänische/Dalmatische/Griechische und Orientalische Reise= Beschreibung. Worin Allerhand merkwïrdige/vormals in Europa unbekannte/ Antiquitäten/enthalten/Welche Jacob Spon/Med. Doctor, und Georgius Wheeler, Englischer von Adel [verfasset]. Nuremberg, 1690.

- Voyage d'Italie, de Dalmatie, de Grece, et du Levant, Fait aux années 1675. E 1676. par Iacob Spon, \& George Wheler Gentilhomme Anglois. Lyons, 1678.

Suetonius. De Vita Caesarum. Edited by J. C. Rolfe. 2 vols. Cambridge: Harvard University Press, 1950-51. 1989.

Tacitus. (Forstner 1652). Ad libros annalium XI. XII. XIII. C. Cornelii Taciti Notae Politicae. Quae sunt continuatio notarum politicarum eiusdem authoris ad sex libros priores. [Leiden]: Lugduni Batavorum, 1652.

- _ The Annals. In The Complete Works of Tacitus. Edited by Moses Hadas and translated by A. J. Church and W. J. Brodribb. New York: Random House, 1942.

- The Annals. Edited and translated by John Jackson. 5 vols. London: Heinemann; Cambridge: Harvard University Press, 1956.

_. (Lipsius). C. Cornelii Tacitii Opera Quae Exstant. A Iusto Lipsio Postremum Recensita, Ejusque Auctis Emendatisque Commentariis Illustrata. . . . Antwerp, 1668.

. (Forstner 1655). Christophori Forstneri Austrii Ad Libros sex priores Annalium C. Cornelii Taciti Notae Politicae. Leiden, 1655.

- (Forstner 1661). In tres postremos libros Annalium C. Cornelii Taciti Notae Politicae. Frankfurt, 1661.

Tertullian. Apologeticus. Edited and translated by T. R. Glover. New York: W. Heinemann, 1960.

G. S. F. Tertulliana Ad Martyras. Edited by Antonio Quacquarelli. Rome and Paris: Désclée, 1963.

Tiraquellus, Andrea. De Legibus Connubialibus, et Jure Maritali. 1515. Reprint, Lyon, 1554.

Valerius Maximus. Actions et paroles mémorables. Edited by Pierre Constant. 2 vols. Paris: Garnier, 1935.

- Valerii Maximi Dictorum Factorumq[ue] Memorabilium Lib. IX Cum I. Lipsii Notis Et Indice uberrimo. Amsterdam, 1660.

Virgil. Aeneid I-VI. Vol. 1. Translated by H. Rushton Fairclough. London: Heinemann, 1960.

— The Aeneid of Virgil. Translated by Allen Mandelbaum. New York: Bantam, 1961.

Wansleben, Johann Michael. [Also Vansleb]. Joh. Mich. Wansleben. Beschreibung des Egyptens Landes nach dem Zustand des Jahres 1664. Von einem reysenden Teutschen in Teutscher Sprach beschrieben. 1671. Manuscript, Niedersächsische Staats- und Universitätsbibliothek, Göttingen. 
- A Brief Account of the Rebellions and Bloudshed Occasioned by the AntiChristian Practices of the Jesuits And Other Popish Emissaries in the Empire of Ethopia. [Attributed to Wansleben]. London, 1678.

- Nouvelle Relation En Forme de Iournal, D'Un Voyage Fait en Egypte Par le P. Vansleb. R.D. En 1672. E 1673. Paris, 1677.

\section{Secondary Sources}

Adam, Wolfgang. "Dichtung und Volkstum und erneuerter Euphorion. Überlegungen zur Namensänderung und Programmatik einer germanistischen Fachzeitschrift." In Zeitenwechsel. Germanistische Literaturwissenschaft vor und nach 1945, edited by Wilfried Barner and Christoph König, 60-75. Frankfurt: Fischer, 1996.

Aikin, Judith Popovich. The Mission of Rome in the Dramas of Daniel Casper von Lohenstein: Historical Tragedy as Prophecy and Polemic. Stuttgart: Akademischer Verlag Hans-Dieter Heinz, 1976.

Alewyn, Richard. Vorwort to Deutsche Barockforschung. Dokumentation einer Epoche, edited by Richard Alewyn, 9-13. Cologne: Kiepenhauer \& Witsch, 1965.

Allgemeine Deutsche Biographie. Leipzig: Duncker and Humblot, 1875-1912.

Appiah, Kwame Anthony. "Geist Stories." In Comparative Literature in the Age of Multiculturalism, edited by Charles Bernheimer, 51-57. Baltimore: Johns Hopkins University Press, 1995.

Asmuth, Bernhard. Daniel Casper von Lohenstein. Stuttgart: Metzler, 1971. -. Lohenstein und Tacitus. Eine quellenkritische Interpretation der NeroTragödien und des Arminius-Roman. Stuttgart: Metzler, 1971.

Auerbach, Erich. "Philology and Weltliteratur." Translated by Maire Said and Edward Said. Centennial Review 13, no. 1 (Winter 1969): 1-17.

Axelrad, A. Jose. Le thème de Sophonisbe dans les principales tragédies de la littérature occidentale. Lille: Bibliothèque Universitaire, 1956.

Bakhtin, M. M. The Dialogic Imagination: Four Essays. Edited by Michael Holquist. Austin: University of Texas Press, 1981.

Banet, Ilona. "Vom Trauerspielautor zum Romanautor. Lohensteins literarische Wende im Lichte der politischen Verhältnisse in Schlesien während des letzten Drittels des 17. Jahrhunderts." Daphnis 12 (1983): 169-86.

Barner, Wilfried. Barockrhetorik. Untersuchungen zu ihren geschichtlichen Grundlagen. Tübingen: Niemeyer, 1970.

__. "Literaturgeschichtsschreibung vor und nach 1945: Alt, neu, alt/neu." In Zeitenwechsel. Germanistische Literaturwissenschaft vor und nach 1945, edited by Wilfried Barner and Christoph König, 119-49. Frankfurt: Fischer, 1996.

- . "Zwischen Gravitation und Opposition. Philologie in der Epoche der Geistesgeschichte." In Literaturwissenschaft und Geistesgeschichte 1910 bis 1925, edited by Christoph König and Eberhart Lämmert, 201-31. Frankfurt: Fischer, 1993. 


\section{Bibliography}

Barner, Wilfried, and Christoph König, eds. Zeitenwechsel. Germanistische Literaturwissenschaft vor und nach 1945. Frankfurt: Fischer, 1996.

Barthelemy, Anthony Gerard. Black Face, Maligned Race: The Representation of Blacks in English Drama from Shakespeare to Southerne. Baton Rouge: Louisiana State University Press, 1987.

Barthes, Roland. Empire of Signs. Translated by Richard Howard. New York: Hill and Wang, 1982.

Becker-Cantarino, Barbara. "Die 'gelehrte Frau' und die Institutionen und Organisationsformen der Gelehrsamkeit am Beispiel der Anna Maria van Schurmann (1607-1678)." In Europäische Hofkultur im 16. und 17. Jahrhundert, 3 vols., edited by August Buck et al., 3:559-76. Hamburg: Hauswedell, 1981.

Béhar, Pierre. Silesia Tragica. Épanouissement et fin de l'école dramatique silésienne dans l'oeuvre tragique de Daniel Casper von Lohenstein (1635-1683). 2 vols. Wiesbaden: Harrassowitz, 1988.

Benjamin, Walter. "Eduard Fuchs, Der Sammler und der Historiker." In Benjamin, Werkausgabe, II-2, edited by Rolf Tiedemann and Hermann Schweppenhäuser, 465-505. Frankfurt: Suhrkamp, 1980.

- Ursprung des deutschen Trauerspiels (1924). In Benjamin, Werkausgabe, I-3, edited by Rolf Tiedemann and Hermann Schweppenhäuser. Frankfurt: Suhrkamp, 1980.

Berman, Russell A. "Three Comments on Future Perspectives on German Cultural History." New German Critique 65 (1995): 115-24.

Bernheimer, Charles. "Introduction: The Anxieties of Comparison." In Comparative Literature in the Age of Multiculturalism, edited by Charles Bernheimer, 1-20. Baltimore: Johns Hopkins University Press, 1995.

Betz, Hans-George. "Mitteleuropa and Post-Modern European Identity." New German Critique 50 (Spring-Summer 1990): 173-92.

Biddick, Kathleen. "Bede's Blush: Postcards from Bali, Bombay, and Palo Alto." In The Past and Future of Medieval Studies, edited by John van Engen, 16-44. Notre Dame, Ind.: University of Notre Dame Press, 1993.

Bietenholz, Peter G., and Thomas B. Deutscher, eds. Contemporaries of Erasmus. 3 vols. Toronto: University of Toronto Press, 1985-87.

Biographie universelle ancienne et moderne. Paris: Michaud, 1826.

Bobertag, Felix. "Die Zweite Schlesische Schule." Kürschners Deutsche NationalLitteratur 36, no. 1 (1885): 111-333.

Boden, Petra. "Julius Petersen: Ein Wissenschaftler auf dem Philologenthron." Euphorion 8, no. 1 (1994): 82-102.

Boose, Lynda E. “'The Getting of a Lawful Race': Racial Discourse in Early Modern England and the Unrepresentable Black Woman." In Women, "Race," and Writing in the Early Modern Period, edited by Margo Hendricks and Patricia Parker, 35-54. London: Routledge, 1994.

Bornstein, George, and Ralph G. Williams, eds. Palimpsest: Editorial Theory in the Humanities. Ann Arbor: University of Michigan Press, 1993.

Borst, Arno. Der Turmbau von Babel: Geschichte der Meinungen über Ursprung und Vielfalt der Sprachen und Völker. 4 vols. Stuttgart: Hiersemann, 1957-63.

Brilling, Bernhard. "Zur Geschichte der Juden in Breslau. Die ersten in Breslau 
wohnhaften Juden 1697-1707." Jahrbuch der Schlesischen Friedrich-WilhelmsUniversität zu Breslau 12 (1967): 126-43.

Brown, Judith C. "A Woman's Place Was in the Home: Women's Work in Renaissance Tuscany." In Rewriting the Renaissance: The Discourses of Sexual Difference in Early Modern Europe, edited by Margaret Ferguson, Maureen Quilligan, and Nancy Vickers, 206-44. Chicago: University of Chicago Press, 1986.

Buci-Glucksmann, Christine. La raison baroque. De Baudelaire à Benjamin. Paris: Éditions Galilée, 1984.

Burckhardt, Jacob. The Civilization of the Renaissance in Italy (1860). Edited and translated by L. Goldscheider. 1944. Reprint, London: Phaidon, 1995.

Burke, Peter. "A Survey of the Popularity of Ancient Historians, 1450-1700." History and Theory (1966): 135-62.

_. "Tacitism." In Tacitus, edited by T. A. Dorey, 148-71. New York: Basic Books, 1969.

Bushnell, Rebecca. Tragedies of Tyrants: Political Thought and Theater in the English Renaissance. Ithaca: Cornell University Press, 1990.

Charlesworth, M. P. "The Fear of the Orient in the Roman Empire." Cambridge Historical Journal 2, no. 1 (1926): 9-15.

Chartier, Roger. The Order of Books: Readers, Authors, and Libraries in Europe between the Fourteenth and the Eighteenth Centuries. Translated by Lydia G. Cochrane. 1992. Reprint, Stanford: Stanford University Press, 1994.

Cochrane, Eric. Historians and Historiography in the Italian Renaissance. Chicago: University of Chicago Press, 1981.

Conrads, Norbert, ed. Schlesien. Deutsche Geschichte im Osten Europas. Berlin: Siedler, 1994.

Correll, Barbara. The End of Conduct. Grobianus and the Renaissance Text of the Subject. Ithaca: Cornell University Press, 1996.

- "Malleable Material, Models of Power: Women in Erasmus's 'Marriage Group' and Civility in Boys." ELH 57 (1990): 241-62.

- "The Politics of Civility in Renaissance Texts: Grobiana in Grobianus." Exemplaria: A Journal in Medieval and Renaissance Studies 2, no. 2 (1990): 62758.

Cranz, F. Edward, and Paul O. Kristeller, eds. Catalogus Translationum et Commentariorum. 7 vols. Washington, D.C.: Catholic University of America Press, 1960-84.

Culler, Jonathan. "Anti-Foundational Philology." In On Philology, edited by Jan Ziolkowski, 49-52. University Park: Pennsylvania State University Press, 1990.

Cysarz, Herbert. Deutsche Barockdichtung. Renaissance-Barock-Rokoko. Leipzig: H. Hässel Verlag, 1924.

—_. "Vom Geist des deutschen Literatur-Barocks." Deutsche Vierteljahresschrift für Literaturwissenschaft und Geistesgeschichte 1 (1924): 243-68.

Czaplicka, John, Andreas Huyssen, and Anson Rabinbach. "Introduction: Cultural History and Cultural Studies-Reflections on a Symposium." New German Critique 65 (1995): 3-18. 
D'Amico, Jack. The Moor in English Renaissance Drama. Tampa: University of South Florida Press, 1991.

D'Amico, John F. Theory and Practice in Renaissance Textual Criticism: Beatus Rhenanus between Conjecture and History. Berkeley: University of California Press, 1988.

Damrosch, David. "The Politics of Ethics: Freud and Rome." In Pragmatism's Freud: The Moral Disposition of Psychoanalysis, edited by Joseph H. Smith and William Kerrigan, 102-25. Baltimore: Johns Hopkins University Press, 1986.

Danneberg, Lutz. "Zur Theorie der werkimmanenten Interpretation." In Zeitenwechsel. Germanistische Literaturwissenschaft vor und nach 1945, edited by Wilfried Barner and Christoph König, 313-45. Frankfurt: Fischer, 1996.

Davis, Natalie Z. "Gender and Genre: Women as Historical Writers, 14001820." In Beyond Their Sex: Learned Women of the European Past, edited by Patricia H. Labalme, 153-82. New York: New York University Press, 1984.

Debrunner, Hans Werner. Presence and Prestige: Africans in Europe. A History of Africans in Europe before 1918. Basel: Basler Afrika Bibliographien, 1979.

Dekker, Rodolf M., and Lotte E. Van de Pol. The Tradition of Female Transvestism in Early Modern Europe. Houndmills: Macmillan, 1989.

de Lauretis, Teresa. "Eccentric Subjects: Feminist Theory and Historical Consciousness." Feminist Studies 16, no. 1 (Spring, 1990): 115-50.

—_. "The Technology of Gender." In de Lauretis, Technologies of Gender: Essays on Theory, Film, and Fiction, 1-30. Bloomington: Indiana University Press, 1987.

Dilthey, Wilhelm. "Die Funktion der Anthropologie in der Kultur des 16. und 17. Jahrhunderts" (1904). In vol. 2 of Dilthey, Weltanschauung und Analyse des Menschen seit der Renaissance und Reformation. Gesammelte Schriften. Leipzig and Berlin: Teubner, 1923.

DuBois, Page. Sappho Is Burning. Chicago: University of Chicago Press, 1995.

Eggers, Dietrich. "Das Breslauer Schultheater unter Christian Gryphius." In Stadt-Schule-Universität-Buchwesen und die deutsche Literatur im 17. Jahrhundert, edited by Albrecht Schöne, 210-24. Munich: Beck, 1976.

Elias, Norbert. The Civilizing Process: The History of Manners. Translated by Edmund Jephcott. New York: Urizen Books, 1978.

Etter, Else-Lilly. Tacitus in der Geistesgeschichte des 16. und 17. Jahrhunderts. Basel and Stuttgart: Helbing und Lichtenhahn, 1966.

Fabian, Johannes. "Ethnographic Objectivity Revisited: From Rigor to Vigor." In Rethinking Objectivity, edited by Alan Megill, 81-108. Durham: Duke University Press, 1994.

Fechner, Jörg-Ulrich. "Klaus Günther Just." Wolfenbüttler Barocknachrichten 4, nos. 3-4 (October 1977): 70-71.

Ferguson, Margaret. "Moderation and Its Discontents: Recent Work on Renaissance Women." Feminist Studies 20, no. 2 (Summer 1994): 349-66.

Festschrift Paul Kluckhohn und Hermann Schneider. Gewidmet zu ihrem 60. Geburtstag. Tübingen: J. C. B. Mohr (Paul Siebeck), 1948.

Fichte, Hubert. "Anmerkungen zu Daniel Casper von Lohensteins Agrippina." In Lohenstein, Lohensteins Agrippina, edited by Fichte, 115-70. Cologne: Kiepenhauer and Witsch, 1978. 
__ “ "Voudoueske Blutbäder-Mischreligiöse Helden. Anmerkungen zu Daniel Casper von Lohensteins 'Agrippina'" (1977). In Die Geschichte der Empfindlichkeit, edited by Gisela Lindemann et al., 141-92. Frankfurt: Suhrkamp, 1987.

Fleming, Donald, and Bernard Bailyn, eds. The Intellectual Migration: Europe and America, 1930-1960. Cambridge: Harvard University Press, 1969.

Fletcher, John. Athanasius Kircher und seine Beziehungen zum gelehrten Europa seiner Zeit. Wiesbaden: Harrassowitz, 1988.

Freud, Sigmund. "Civilization and Its Discontents." In The Standard Edition of the Complete Psychological Work of Sigmund Freud, 24 vols., edited and translated by James Strachey and Anna Freud, 21:57-243. London: Hogarth Press and Institute of Psycho-Analysis, 1953-74.

Friese, Wilhelm. "Christina, Königin von Schweden." In Europäische Hofkultur im 16. und 17. Jahrhundert, 3 vols., edited by August Buck et al., 3:475-81. Hamburg: Hauswedell, 1981.

Fülleborn, Ulrich. Die barocke Grundspannung Zeit-Ewigkeit in den Trauerspielen Lohensteins. Stuttgart: Metzler, 1969.

Garber, Klaus. Rezeption und Rettung. Drei Studien zu Walter Benjamin. Tübingen: Niemeyer, 1987.

Garber, Marjorie. Shakespeare's Ghost Writers: Literature as Uncanny Causality. New York: Methuen, 1987.

- Vested Interests: Cross-Dressing and Cultural Anxiety. New York: Routledge, 1992.

Gascoigne, Bamber. Illustrierte Weltgeschichte des Theaters. 1968. Reprint, Munich and Vienna: Langen-Müller, 1971.

Geertz, Clifford. Local Knowledges: Further Essays in Interpretive Anthropology. New York: Basic Books, 1983.

- "Thick Description: Toward an Interpretive Theory of Culture." In Geertz, The Interpretation of Cultures, 3-32. New York: Basic Books, 1973.

Gillespie, Gerald Ernest Paul. Daniel Casper von Lohenstein's Historical Tragedies. Columbus: Ohio State University Press, 1965.

- . "Lohenstein's Epicharis: The Play of the Beautiful Loser." In Studien zum Werk Daniel Caspers von Lohenstein: anläßlich der 300. Wiederkehr des Todesjahres, edited by Gerald Gillespie and Gerhard Spellerberg, 127-57. Amsterdam: Rodopi, 1983. (= Daphnis 2-3).

Ginzburg, Carlo. "Morelli, Freud, and Sherlock Holmes: Clues and Scientific Method." History Workshop 9 (1980): 5-36.

Gordon, D. J. "Giannotti, Michelangelo, and the Cult of Brutus." In The Renaissance Imagination, edited by Stephen Orgel, 233-46. Berkeley: University of California Press, 1975.

Gössmann, Elisabeth, ed. Das Wohlgelahrte Frauenzimmer. Munich: Iudicium, 1984.

—_. Eva: Gottes Meisterwerk. Munich: Iudicium, 1985.

Grafton, Anthony. Defenders of the Text: The Traditions of Scholarship in an Age of Science, 1450-1800. Cambridge: Harvard University Press, 1991.

1997. 


\section{Bibliography}

- "Renaissance Readers and Ancient Texts: Comments on Some Commentaries." Renaissance Quarterly 38 (1985): 615-49.

Grafton, Anthony, and Lisa Jardine. From Humanism to the Humanities: Education and the Liberal Arts in Fifteenth-and Sixteenth-Century Europe. Cambridge: Harvard University Press, 1986.

Greenblatt, Stephen. "Fiction and Friction." In Greenblatt, Shakespearean Negotiations: The Circulation of Social Energy in the Renaissance, 66-93. Berkeley: University of California Press, 1988.

Greene, Thomas M. The Light in Troy: Imitation and Discovery in Renaissance Poetry. New Haven: Yale University Press, 1982.

—_. "Petrarch and the Humanist Hermeneutic." In Italian Literature: Roots and Branches, edited by Giose Rimanelli and Kenneth John Atchity, 201-24. New Haven: Yale University Press, 1976.

Greetham, D. C. "Editorial and Critical Theory: From Modernism to Postmodernism." In Palimpsest: Editorial Theory in the Humanities, edited by George Bornstein and Ralph G. Williams, 9-28. Ann Arbor: University of Michigan Press, 1993.

—_. "The Manifestation and Accommodation of Theory in Textual Editing." In Devils and Angels: Textual Editing and Literary Theory, edited by Philip Cohen, 78-102. Charlottesville: University Press of Virginia, 1991.

Grünhagen, Kolmar. Geschichte Schlesiens. 2 vols. Gotha: Friedrich Andreas Perthes, $1884-86$.

Guillory, John. Cultural Capital: The Problem of Literary Canon Formation. Chicago: University of Chicago Press, 1993.

Hall, Kim F. "'I Rather Would Wish to Be a Black-Moor': Beauty, Race, and Rank in Lady Mary Wroth's Urania." In Women, "Race," and Writing in the Early Modern Period, edited by Margo Hendricks and Patricia Parker, 178-94. London: Routledge, 1994.

-. "Sexual Politics and Cultural Identity in The Masque of Blackness." In The Performance of Power: Theatrical Discourse and Politics, edited by Sue-Ellen Case and Janelle Reinelt, 3-18. Iowa City: University of Iowa Press, 1991.

- Things of Darkness: Economies of Race and Gender in Early Modern England. Ithaca: Cornell University Press, 1995.

Halpern, Richard. The Poetics of Primitive Accumulation: English Renaissance Culture and the Genealogy of Capital. Ithaca: Cornell University Press, 1991.

Hampton, Timothy. Writing from History: The Rhetoric of Exemplarity in Renaissance Literature. Ithaca: Cornell University Press, 1990.

Haraway, Donna. "A Manifesto for Cyborgs: Science, Technology, and Socialist Feminism in the 1980s." In Feminism/Postmodernism, edited by Linda Nicholson, 190-233. New York: Routledge, 1990.

Harding, Sandra. The "Racial" Economy of Science: Toward a Democratic Future. Bloomington: Indiana University Press, 1993.

Hayles, N. Katherine. Chaos Bound: Orderly Disorder in Contemporary Literature and Science. Ithaca: Cornell University Press, 1990.

Hendricks, Margo. "Managing the Barbarian: The Tragedie of Dido, Queen of Carthage." Renaissance Drama, n.s., 23 (1992): 165-88. 
Hendricks, Margo, and Patricia Parker, eds. Women, "Race," and Writing in the Early Modern Period. London: Routledge, 1994.

Hermand, Jost. Geschichte der Germanistik. Reinbek bei Hamburg: Rowohlt, 1994.

Hexter, Ralph, "Sidonian Dido." In Innovations of Antiquity, edited by Ralph Hexter and Daniel Selden, 332-90. New York: Routledge, 1992.

Hippe, Max. "Aus dem Tagebuche eines Breslauer Schulmannes im 17. Jahrhundert." Zeitschrift des Vereins für Geschichte und Alterthum Schlesiens 36 (1901): 159-92.

Horstmann, A. "Philologie." In Philosophisches Wörterbuch der Philosophie, edited by Joachim Ritter and Karlfried Gründer, cols. 552-72. Basel: Schwabe, 1989.

Howard, Jean. The Stage and Social Struggle in Early Modern England. London: Routledge, 1994.

Hughes-Hallett, Lucy. Cleopatra: Histories, Dreams, and Distortions. New York: Harper Collins, 1990.

Hull, Suzanne W. Chaste, Silent and Obedient: English Books for Women, 1475-1640. San Marino: Huntington Library, 1982.

Irigaray, Luce. "This Sex Which Is Not One" (1977). In Irigaray, This Sex Which Is Not One, 23-33. Translated by Catherine Porter with Carolyn Burke. Ithaca: Cornell University Press, 1985.

Jankowski, Theodora A. Women in Power in the Early Modern Drama. Urbana: University of Illinois Press, 1992.

Jardine, Lisa. Still Harping on Daughters: Women and Drama in the Age of Shakespeare. Sussex: Harvester Press, 1983.

Jed, Stephanie H. Chaste Thinking: The Rape of Lucretia and the Birth of Humanism. Bloomington: Indiana University Press, 1989.

Jöcher, Christian Gottlieb. Allgemeines Gelehrten-Lexicon. 5 vols. Leipzig: Gleditschen, $1750-51$.

Johnson, Barbara. "Philology: What Is at Stake?" In On Philology, edited by Jan Ziolkowski, 26-30. University Park: Pennsylvania State University Press, 1990.

Jones, Ann Rosalind. "Assimilation with a Difference: Renaissance Women Poets and Literary Influence." Yale French Studies 62 (1981): 135-53.

Jordan, Constance. Renaissance Feminism: Literary Texts and Political Models. Ithaca: Cornell University Press, 1990.

Juretzka, Jörg C. Zur Dramatik Daniel Caspers von Lohenstein. 'Cleopatra' 1661 und 1680. Meisenheim am Glan: Verlag Anton Hain, 1976.

Just, Klaus Günther. “Lohenstein und seine Welt.” Schlesien 6 (1961): 239-42.

__ "Neue Schlesische Barockliteratur. Marian Szyrocki/Martin OpitzDer junge Gryphius." Schlesien 6 (1961): 52-53.

- Die Trauerspiele Lohensteins. Versuch einer Interpretation. Berlin: Erich Schmidt Verlag, 1961.

Kahn, Coppelia. Roman Shakespeare: Warriors, Wounds, and Women. London: Routledge, 1997.

Kelly, Joan. "Did Women Have a Renaissance?" (1977). In Kelly, Women, History, and Theory, 19-50. Chicago: Chicago University Press, 1984. 


\section{Bibliography}

Kenney, E. J. The Classical Text:. Aspects of Editing in the Age of the Printed Book. Berkeley: University of California Press, 1974.

Kiesant, Knut. "Die Wiederentdeckung der Barockliteratur. Leistungen und Grenzen der Barockbegeisterung der zwanziger Jahre." In Literaturwissenschaft und Geistesgeschichte 1910 bis 1925, edited by Christoph König and Eberhard Lämmert, 77-91. Frankfurt: Fischer, 1993.

King, Katie. "Bibliography and a Feminist Apparatus of Literary Production." Text: Transactions of the Society for Textual Scholarship 5 (1991): 91-103.

. Theory in Its Feminist Travels: Conversations in U.S. Women's Movements. Bloomington: Indiana University Press, 1994.

King, Margaret L. Women of the Renaissance. Chicago: Chicago University Press, 1991.

Kleinschmidt, Erich. "Gelehrte Frauenbildung und frühneuzeitliche Mentalität." In Res Publica Litteraria: Die Institutionen der Gelehrsamkeit in der frühen Neuzeit, 2 vols., edited by Sebastian Neumeister and Conrad Wiedemann, 2:549-57. Wiesbaden: Harrassowitz, 1987.

König, Christoph. "Eine Rekonstruktion nach dem Bruch." In Germanistik in Mittel- und Osteuropa, 1945-1992, edited by Christoph König, 1-8. Berlin and New York: de Gruyter, 1995.

König, Christoph, and Eberhard Lämmert, eds. Literaturwissenschaft und Geistesgeschichte 1910 bis 1925. Frankfurt: Fischer, 1993.

Koselleck, Reinhart. "Historia Magistra Vitae. Über die Auflösung des Topos im Horizont neuzeitlich bewegter Geschichte." In Natur und Geschichte. Karl Löwith zum 70. Geburtstag, edited by Hermann Braun and Manfred Riedl, 196-219. Stuttgart: W. Kohlhammer, 1967.

Kühlmann, Wilhelm. Gelehrtenrepublik und Fürstenstaat. Entwicklung und Kritik des deutschen Späthumanismus in der Literatur des Barockzeitalters. Tübingen: Niemeyer, 1982.

___ "Geschichte als Gegenwart: Formen der politischen Reflexion im deutschen Tacitismus." In Res Publica Litteraria. Die Institutionen der Gelehrsamkeit in der frühen Neuzeit, 2 vols., edited by Sebastian Neumeister and Conrad Wiedemann, 1:325-48. Wiesbaden: Harrassowitz, 1987.

Landow, George P. "What's a Critic to Do? Critical Theory in the Age of Hypertext." In Hyper/Text/Theory, edited by George P. Landow, 1-50. Baltimore: Johns Hopkins University Press, 1994.

Laqueur, Thomas. Making Sex: Body and Gender from the Greeks to Freud. Cambridge: Harvard University Press, 1990.

Lauter, Paul. Canons and Contexts. New York: Oxford University Press, 1991.

Levine, Laura. Men in Women's Clothing: Anti-Theatricality and Effeminization, 1579-1642. Cambridge: Cambridge University Press, 1994.

Levine, Lawrence W. The Opening of the American Mind: Canons, Culture, and History. Boston: Beacon Press, 1996.

Little, Arthur. "'An Essence That's Not Seen': The Primal Scene of Racism in Othello." Shakespeare Quarterly 44 (Fall 1993): 302-24.

Lord, Mary Louise. "Dido as an Example of Chastity: The Influence of Example Literature." Harvard Library Bulletin 17 (1969): 22-44, 216-32. 
Lougee, Carolyn C. Le paradis des femmes: Women, Salons, and Social Stratification in Seventeenth-Century France. Princeton: Princeton University Press, 1976.

Lucae, Friedrich. Schlesiens curieuse Denckwürdigkeiten. Frankfurt, 1689.

Lunding, Erik. Das schlesische Kunstdrama. Eine Darstellung und Deutung. Copenhagen: P. Haase \& Sons, 1940.

Lupton, Julia Reinhard. Afterlives of the Saints: Hagiography, Typology, and Renaissance Literature. Stanford: Stanford University Press, 1996.

Maclean, Ian. The Renaissance Notion of Woman: A Study in the Fortunes of Scholasticism and Medical Science in European Intellectual Life. Cambridge: Cambridge University Press, 1980.

-. Woman Triumphant: Feminism in French Literature, 1610-1652. Oxford: Clarendon Press, 1977.

Marcus, Leah S. "Renaissance/Early Modern Studies." In Redrawing the Boundaries: The Transformation of English and American Literary Studies, edited by Stephen Greenblatt and Giles Gunn, 41-63. New York: MLA, 1992.

- Unediting the Renaissance: Shakespeare, Marlowe, Milton. London: Routledge, 1996.

Martino, Alberto. Daniel Casper von Lohenstein. Geschichte seiner Rezeption. Vol. 1: 1661-1800. 1975. Transl. Heribert Streicher. Tübingen: Niemeyer, 1978.

McDonald, A. H. "Titius Livius." In Catalogus Translationum et Commentariorum, 7 vols., edited by F. Edward Cranz and Paul O. Kristeller, 2:331-48. Washington, D.C.: Catholic University of America Press, 1960-84.

McGann, Jerome J. "Literary Pragmatics and the Editorial Horizon." In Devils and Angels: Textual Editing and Literary Theory, edited by Philip Cohen, 1-21. Charlottesville: University of Virginia Press, 1991.

-_ . "The Monks and the Giants. Textual and Bibliographical Studies and the Interpretation of Literary Works." In Textual Criticism and Literary Interpretation, edited by Jerome J. McGann, 180-200. Chicago: University of Chicago Press, 1985.

- ed. Textual Criticism and Literary Interpretation. Chicago: University of Chicago Press, 1985.

McLuskie, Kathleen. Renaissance Dramatists. Atlantic Highlands, N.J.: Humanities Press International, 1989.

Megill, Allan. "Introduction: Four Senses of Objectivity." In Rethinking Objectivity, edited by Allan Megill, 1-20. Durham: Duke University Press, 1994.

Menhennet, Alan. "The Death of Lohenstein's Agrippina." Quinquérème 6 (1983): 28-38.

Meyer-Kalkus, Reinhart. Wollust und Grausamkeit. Affektenlehre und Affektdarstellung in Lohensteins Dramatik am Beispiel von "Agrippina." Göttingen: Vandenhoeck \& Ruprecht, 1986.

Migiel, Marilyn, and Juliana Schiesari, eds. Refiguring Woman: Perspectives on Gender and the Italian Renaissance. Ithaca: Cornell University Press, 1991.

Moeller, Robert G. "War Stories: The Search for a Usable Past in the Federal Republic of Germany." American Historical Review 101, no. 4 (October, 1996): $1008-48$. 
Momigliano, Arnaldo. "Ancient History and the Antiquarian." Journal of the Warburg and Courtauld Institutes 13 (1950): 285-315.

- "Tradition and the Classical Historian." History and Theory 11 (1972): 279-93.

Montrose, Louis Adrian. "Shaping Fantasies: Figurations of Gender and Power in Elizabethan Culture." Representations 1 (1983): 61-94.

Mulagk, Karl-Heinz. Phänomene des politischen Menschen im 17. Jahrhundert. Propädeutische Studien zum Werk Lohensteins unter besonderer Berücksichtigung Diego Saavedra Fajardos und Balthasar Gracians. Berlin: Schmidt, 1973.

Müller, Conrad. Beiträge zum Leben und Dichten Daniel Caspers von Lohenstein. Breslau: Wilhelm Koebner, 1882. Reprint, Hildesheim: Olms, 1977.

Müller, Hans von. "Bibliographie der Schriften Daniel Caspers von Lohenstein, 1652-1748." In Werden und Wirken. Festgruß für K. W. Hiersemann, edited by Martin Breslauer and Kurt Koehler, 184-261. Leipzig: K. F. Koehler, 1924.

Newman, Jane O. "'Academic Tootsie': Women's Voices, Gender, and Textual Ventriloquism in the German Language Academies." Eighteenth Century: Theory and Interpretation 35, no. 3 (1994): 241-60.

—_. "Baroque Legacies: National Socialism's Benjamin." Paper presented in the session "Humanism under Fascism" at the 1997 MLA Convention (Toronto).

—_ "Citational Science: Textuality and the Authority of the 'Scientific Fact' in Early Modern Central Europe (Lohenstein's Cleopatra, 1680)." In The Construction of Textual Authority in German Literature of the Medieval and Early Modern Periods, edited by Claire Baldwin and James Poag. Chapel Hill: University of North Carolina Press, forthcoming.

—. "Disorientations: Same-Sex Seduction and Women's Power in Daniel Casper von Lohenstein's Ibrahim Sultan (1673)." Colloquia Germanica 28, nos. 3-4 (1995): 337-55.

. "(Post) Cold War Renaissance Studies, or: Being 'Historical' with Early Modern (Western) European Literary History." Paper presented at the UCSD Humanities Center Conference on History and Literature: The Historical Imagination at Century's End, San Diego, February 1, 1997.

-. "Textual Reproduction and the Politics of the Edition: Spellerberg on Just on Lohenstein." In Studien zur Literatur des 17. Jahrhunderts. Gedenkschrift für Gerhard Spellerberg (1937-1996), edited by Hans Feger. CHLOE: Beihefte zum Daphnis (1997): 1-23.

Newton, Judith, and Deborah Rosenfelt. "Introduction: Toward a MaterialistFeminist Criticism." In Feminist Criticism and Social Change: Sex, Class, and Race in Literature and Culture, edited by Judith Newton and Deborah Rosenfelt, xv-xxxix. New York: Methuen, 1985.

Oellers, Norbert. “Editionswissenschaft um 1945." In Zeitenwechsel. Germanistische Literaturwissenschaft vor und nach 1945, edited by Wilfried Barner and Christoph König, 103-18. Frankfurt: Fischer, 1996.

Oestreich, Gerhard. "Lohensteins Zeit und Umwelt." In Epicharis: Die Welt des Daniel Casper von Lohenstein, edited by Peter Kleinschmidt et al., 7-33. Cologne: Wienand Verlag, 1978. 
Ong, Walter. "Latin Language Study as a Renaissance Puberty Rite." Studies in Philology 56 (1959): 103-24.

Orgel, Stephen. "Nobody's Perfect: Or Why Did the English Stage Take Boys for Women?" South Atlantic Quarterly 88, no. 1 (1989): 7-29.

Parker, Patricia. "Rhetorics of Property: Exploration, Inventory, Blazon." In Parker, Literary Fat Ladies: Rhetoric, Gender, Property, 126-54. London: Methuen, 1987.

Peters, Edward. Torture. Oxford: Oxford University Press, 1985.

Petry, Ludwig, and Josef Joachim Menzel, eds. Geschichte Schlesiens. 3 vols. Sigmaringen: Jan Thorbecke Verlag, 1988.

Pigman, George. "Versions of Imitation in the Renaissance." Renaissance Quarterly 1 (1980): 1-32.

Pitkin, Hanna. Fortune Is a Woman: Gender and Politics in the Thought of Niccolo Machiavelli. Berkeley: University of California Press, 1984.

Pocock, J. G. A. "Deconstructing Europe" (1991). In The Question of Europe, edited by Peter Gowan and Perry Anderson, 297-317. London: Verso, 1997.

Pratt, Mary Louise. Imperial Eyes: Travel Writing and Transculturation. New York: Routledge, 1992.

Quilligan, Maureen. The Allegory of Female Authority: Christine de Pisan's "Cité des Dames." Ithaca: Cornell University Press, 1991.

Quint, David. "'Alexander the Pig': Shakespeare on History and Poetry." Boundary 210 (1982): 49-67.

-. "Epic and Empire." Comparative Literature 41, no. 1 (Winter 1989): 1-32.

__. "Voices of Resistance: The Epic Curse and Camoes's Adamastor." Representations 27 (1989): 111-41.

Reinhold, Meyer. From Republic to Principate: An Historical Commentary on Cassius Dio's "Roman History": Books 49-52 (36-29 B.C.). Atlanta: Scholars Press, 1988.

Reynolds, Beatrice. "Shifting Currents in Historical Criticism." In Renaissance Essays, edited by Paul O. Kristeller and Philip P. Wiener, 115-36. New York: Harper and Row, 1968.

Ricci, Charles. Sophonisbe dans la tragédie classique italienne et française. Turin: G. B. Paravia, 1904.

Richard, Carl J. The Founders and the Classics: Greece, Rome, and the American Enlightenment. Cambridge: Harvard University Press, 1994.

Riffaterre, Michael. "Interview." Diacritics 11 (1981): 12-16.

Rizzo, Silvia. Il lessico filologico degli umanisti. Rome: Edizioni di Storia e Letteratura, 1973.

Roelofsen, C. G. "Grotius and the International Politics of the Seventeenth Century." In Hugo Grotius and International Relations, edited by Hedley Bull et al., 95-131. Oxford: Clarendon Press, 1990.

Ronzeaud, Pierre. "La femme au pouvoir ou le monde à l'envers." XVIIème Siècle 108 (1975): 9-33.

Rubin, Gayle. "The Traffic in Women: Notes on the 'Political Economy' of Sex." In Toward an Anthropology of Women, edited by Rayna R. Reiter, 157-210. New York: Monthly Review Press, 1975. 
Rüdiger, Horst. “Die Wiederentdeckung der antiken Literatur im Zeitalter der Renaissance." In Geschichte der Textüberlieferung der antiken und mittelalterlichen Literatur, 2 vols., edited by Herbert Hunger et al., 1:511-76. Zurich: Atlantis Verlag, 1961-64.

Samuel, Irene. "Semiramis in the Middle Ages: The History of a Legend." Medievalia et Humanistica 2 (1944): 32-44.

Schaffer, Simon. "Gestures in Question." In Questions of Evidence: Proof, Practice, and Persuasion across the Disciplines, edited by James Chandler et al., 98-104. Chicago: University of Chicago Press, 1994.

Schellhase, Kenneth C. Tacitus in Renaissance Political Thought. Chicago: University of Chicago Press, 1976.

Schindel, Ulrich. "Antike Historie im Unterricht der gelehrten Schule des 17. Jahrhunderts." In Stadt-Schule-Universität-Buchwesen und die deutsche Literatur im 17. Jahrhundert, edited by Albrecht Schöne, 225-42. Munich: Beck, 1976.

Schlesinger, Maximilian. Geschichte des Breslauer Theaters. Vol. 1. Breslau: Wilhelm Koebner, n.d. Reprint, Berlin: S. Fischer, 1898.

Schlumbohm, Christa. "Die Glorifizierung der Barockfürstin als 'Femme forte.'" In Europäische Hofkultur im 16. und 17. Jahrhundert, 2 vols., edited by August Buck et al., 2:113-22. Hamburg: Hauswedell, 1981.

Schöffler, Herbert. Deutscher Osten im deutschen Geist. Von Martin Opitz zu Christian Wolff. Frankfurt: V. Klostermann, 1940.

Schück, C. E. “Drei schlesische Fürstenfrauen." Zeitschrift des Vereins für Geschichte und Altertum Schlesiens 8 (1867): 73-108.

Scott, Joan W. "Gender: A Useful Category of Historical Analysis." In Coming to Terms: Feminism, Theory, Politics, edited by Elizabeth Weed, 81-100. New York: Routledge, 1989.

Sedgwick, Eve Kosofsky. Epistemology of the Closet. Berkeley: University of California Press, 1990.

Shapiro, Barbara. "History and Natural History in Sixteenth- and SeventeenthCentury England: An Essay on the Relationship between Humanism and Science." In English Scientific Virtuosi in the 16th and 17th Centuries: Papers read at a Clark Library Seminar, 5 February, 1979, edited by Barbara Shapiro and Robert G. Frank Jr., 3-55. University of California, Los Angeles: William Andrews Clark Memorial Library, 1979.

Slights, William W. E. "The Edifying Margins of Renaissance English Books." Renaissance Quarterly 42, no. 4 (Winter 1989): 682-716.

Spellerberg, Gerhard. "Eine unbeachtete Quelle zur Epicharis Daniel Caspers von Lohenstein." Euphorion 61 (1967): 143-54.

_. "Lohensteins Beitrag zum Piasten-Mausoleum in der Liegnitzer Johannis-Kirche." Daphnis 7, no. 4 (1978): 647-87.

-. "Lohensteins' Sophonisbe. Geschichtliche Tragödie oder Drama von Schuld und Strafe?" Daphnis 12, nos. 2-3 (1983): 375-401.

_. "Das schlesische Barockdrama und das Breslauer Schultheater." In Epicharis. Die Welt des Daniel Casper von Lohenstein, edited by Peter Kleinschmidt et al., 58-69. Cologne: Weinand, 1978. 
- "Szenare zu den Breslauer Aufführungen Lohensteinischer Trauerspiele." Daphnis 7, no. 4 (1978): 629-45.

- Verhängnis und Geschichte. Untersuchungen zu den Trauerspielen und dem "Arminius"-Roman Daniel Caspers von Lohenstein. Berlin and Zurich: Verlag Gehlen, 1970.

—. "Zur Sophonisbe Daniel Casper von Lohenstein." In Literaturwissenschaft und Geschichtsphilosophie. Festschrift für Wilhelm Emrich, edited by Helmut Arntzen, 239-63. Berlin and New York: de Gruyter, 1975.

Stachel, Paul. Seneca und das deutsche Renaissancedrama. Studien zur Literaturund Stilgeschichte des 16. und 17. Jahrhunderts. Palaestra 46. Berlin: Erich Schmidt Verlag, 1907.

Stein, Wolfgang Hans. “Christoph Forstner 1598-1668. Mömpelgardische Politik und Humanistische Reflexion auf dem Westfälischen Friedenskongress." In Forschungen und Quellen zur Geschichte des Dreißigjährigen Krieges, edited by Konrad Repgen, 62-97. Münster: Aschendorff, 1981.

Steiner, Uwe. “Allegorie und Allergie. Bemerkungen zur Diskussion um Benjamins Trauerspielbuch in der Barockforschung." Daphnis 18, no. 4 (1989): 641-701.

Strich, Fritz. Deutsche Klassik und Romantik oder Vollendung und Unendlichkeit. Ein Vergleich. Bern: Francke, 1922.

__. "Der lyrische Stil des 17. Jahrhunderts" (1916). In Deutsche Barockforschung. Dokumentation einer Epoche, edited by Richard Alewyn, 229-59. Cologne: Kiepenheuer \& Witsch, 1965.

Szucs, Jeno. Die drei historischen Regionen Europas. Eine Studie. Frankfurt: Suhrkamp, 1990.

Tanselle, G. Thomas. Textual Criticism and Scholarly Editing. Charlottesville: University Press of Virginia, 1990.

Tribble, Evelyn B. Margins and Marginality. The Printed Page in Early Modern England. Charlottesville: University Press of Virginia, 1993.

Trunz, Erich. "Die Erforschung der deutschen Barockdichtung. Ein Bericht über Ergebnisse und Aufgaben." Deutsche Vierteljahresschrift für Literaturwissenschaft und Geistesgeschichte 18 (1940), Referatenheft: 1-100.

_. "Erinnerungen an Julius Petersens Seminar 'Deutsche Barocklyrik' im Wintersemester 1927/28 an der Universität Berlin." Wolfenbüttler BarockNachrichten 5: 1 (1978): 123-311.

Uhlig, Siegbert. Hiob Ludolfs "Theologia Aethiopica." Aethiopische Forschungen 14. Wiesbaden: Steiner, 1983.

Vajda, Mihaly. "Die Bedeutung von 'Mitteleuropa.'” In Germanistik in Mittelund Osteuropa, 1945-1992, edited by Christoph König, 51-62. Berlin and New York: de Gruyter, 1995.

Vickers, Nancy J. “'The Blazon of Sweet Beauty's Best': Shakespeare's Lucrece." In Shakespeare and the Question of Theory, edited by Patricia Parker and Geoffrey Hartmann, 95-115. New York: Methuen, 1985.

_. "Diana Described: Scattered Women and Scattered Rhyme." In Writing and Sexual Difference, edited by Elizabeth Abel, 95-110. Chicago: University of Chicago Press, 1982. 
Wall, Wendy. The Imprint of Gender: Authorship and Publication in the English Renaissance. Ithaca: Cornell University Press, 1993.

Watkins, Calvert. "What Is Philology?" In On Philology, edited by Jan Ziolkowski, 21-25. University Park: Pennsylvania State University Press, 1990.

Weisinger, Herbert. "Ideas of History during the Renaissance." In Renaissance Essays, edited by Paul O. Kristeller and Philip P. Wiener, 74-94. New York: Harper and Row, 1968.

White, Hayden. Metahistory: The Historical Imagination in Nineteenth-Century Europe. Baltimore: Johns Hopkins University Press, 1973.

Wichert, Adalbert. Literatur, Rhetorik, und Jurisprudenz im 17. Jahrhundert. Daniel Casper von Lohenstein und sein Werk. Eine exemplarische Studie. Tübingen: Niemeyer, 1991.

Wiesner, Merry E. Women and Gender in Early Modern Europe. Cambridge: Cambridge University Press, 1993.

- Working Women in Renaissance Germany. New Brunswick: Rutgers University Press, 1986.

Williams, Ralph G. "I Shall Be Spoken: Textual Boundaries, Authors, and Intent." In Palimpsest: Editorial Theory in the Humanities, edited by George Bornstein and Ralph G. Williams, 45-66. Ann Arbor: University of Michigan Press, 1993.

Witkowski, G. J., and L. Nass. Le nu au théâtre depuis l'antiquité. Paris: le François, 1914.

Wolff, Larry. Inventing Eastern Europe: The Map of Civilization on the Mind of the Enlightenment. Stanford: Stanford University Press, 1994.

Wolin, Richard. Walter Benjamin: An Aesthetic of Redemption. 2nd ed. Berkeley: University of California Press, 1994.

Woods, Jean M. “Das 'Gelahrte Frauenzimmer' und die deutschen Frauenlexika 1631-1743." In Europäische Hofkultur im 16. und 17. Jahrhundert, 3 vols., edited by August Buck et al., 3:577-87. Hamburg: Hauswedell, 1981.

Zentner, Christian, and Friedemann Bedürftig, eds. The Encyclopedia of the Third Reich. English Translation edited by Amy Hackett. 2 vols. New York: Macmillan, 1991.

Zetzel, James E. G. "Religion, Rhetoric, and Editorial Technique: Reconstructing the Classics." In Palimpsest: Editorial Theory in the Humanities, edited by George Bornstein and Ralph G. Williams, 99-120. Ann Arbor: University of Michigan Press, 1993.

Zielske, Harald. "Andreas Gryphius' Trauerspiel 'Catharina von Georgien' als 'Festa Teatrale' des Barock-Absolutismus." Veröffentlichungen der Forschungsstelle Osteuropas A-39, edited by Johannes Hoffmann, 1-32. Dortmund: Forschungsstelle Osteuropas, 1983. 


\section{Index}

Acte (Nero's mistress), 109, 127

Aelianus, Claudius, 117-19

Aethiops, 154

Agrippina: parallels to Semiramis, 1069,114-16, 118; incestuous behavior and political actions of, 110-11, 12527; as parallel to Dido, 194-95 (n. 41). See also Lohenstein, Daniel Casper von-Agrippina

Ambrose, 89-92

Ammianus Marcellinus, 97-100

Anaxarchus, 89-92, 96, 99

Anicetus (Nero's advisor), 114-15, 120

Anmerckungen (notes to Lohenstein's plays), 8, 18-19, 88, 103, 110, 128, 158

Antony, Marc (Antonius/Antoine), 142, 145-49

Appian, as source for Sophonisbe, 37, 40, $47,52,64-70$

Asmuth, Bernhard, 84, 86, 143, 182 (n. 12), 188-89 (n. 2), 193 (n. 19), 196 (n. 3), 197 (n. 27)

Athenaeus, 89

Auerbach, Erich, 184 (n. 46)

Augustine, 118-19

Augustus Caesar (Octavian), 42, 71, 131, $140-46,150-52,158$

Bakhtin, M. M., The Dialogic Imagination, 184 (n. 54)

Barner, Wilfried, 168, 183 (n. 40), 184-85 (n. 69), 200 (n. 16)

Baroque studies, 4, 6, 22, 177-78; cited by Benjamin, $160-62$; under National Socialism, 163-64; post-World War II, 166-71

Barthelemy, Anthony Gerard, 140

Béhar, Pierre, 95, 196 (n. 3), 197-98 (n. 39), 198 (n. 40), 199 (n. 57)

Benjamin, Walter, 17, 174, 177; Ursprung des deutschen Trauerspiels (Origin of the German tragic drama) (1928), 159-64, 181-82 (n. 7); suicide of, 164
Benserade, Isaac de, La Cléopâtre (1636), as source for Cleopatra, 143-46, 157-58

Berlin, xi, 160, 162-64

Berman, Russell, 178, 201 (nn. 35, 37)

Bernegger, Matthias, 68, 119-22

Bibliothek des literarischen Vereins, 169-73

Biddick, Kathleen, 176, 183 (n. 24)

Blazon, usage of, 146-51

Boccaccio, Giovanni, 66-67, 70

-De mulieribus claris (Concerning famous women) (1355): Sophonisbe story in, 54-57, 188 (n. 1); Epicharis story in, 86; Semiramis story in, 114-15, 117; Cleopatra story in, 142

Bochart, Samuel, 67-70, 156-58

Boecler, Johann Heinrich, 121-22

Boose, Lynda E., 197 (nn. 30, 37)

Breslau (Wroclaw): city council's supervision of plays, 5, 79-80, 101; relationship of to Vienna, 18, 39; history of, 25, 32-36; city council, 33-34, 80

Brisson, Barnabas, as source for Agrippina, 113

Brutus, Lucius Junius, $42-46,66$

Brutus, Marcus, 42-43, 46

Burckhardt, Jakob, 3, 77

Burke, Peter, 19, 57

Burrhus, 109

Caesar, Julius, 42, 128, 140-41

Caesarion (son of Cleopatra and Julius Caesar), 128-31, 140-43, 146

Carpzov, Benedikt, Practica rerum criminalium (Practices in criminal matters) (1635), as source for Epicharis, 94, 18889 (n. 2)

Cassirer, Ernst, 3

Central Europe: and early modern studies, 3-4; definitions of, 181 (n. 5)

Chartier, Roger, 7, 182 (n. 17)

Chaucer, 142

Christina (queen of Sweden), 106, 125 
Cleopatra, 142; and Sophonisbe, 50; race of, 130-31, 140; and Ptolemaic dynasty, 153-54. See also Lohenstein, Daniel Casper von-Cleopatra

Cold War, xi, 2-3, 24, 169-74, 177, 183 (n. 30)

Correll, Barbara, 78-80, 182 (n. 13)

Cosmas (Indicopleustes), as source for Cleopatra, 154-57

Cross-dressing: on Elizabethan stage, $4,7-$ 8; by Breslau boy actors, 5, 7, 21, 80, 175; in Sophonisbe, 47-58, 62; by Epicharis, 84-85; in Epicharis, 95-96, 100

Criticism, textual, 14; theory of, 165

Culler, Jonathan, 13-14

Cysarz, Herbert, Benjamin's citation of, 160-63

D'Amico, Jack, 198 (n. 42)

D'Amico, John, 187 (n. 19)

Dante, 65, 142

Desmarets de Saint-Sorlin, Jean, Ariane (1632), as source for Epicharis, 84-88, 93

Dido: in Sophonisbe, 59-60, 66-72; in Virgil's Aeneid, 60-65; pre-Virgilian versions of, 61, 64-66; in Justinus Frontinus, 66-67; in Bochart's De Quaestione: Num Aeneas umquam fuerit in Italia?, 67; parallels with Hannibal, 68; Hendreich's De Respublica Carthaginensium, 69; in Boccaccio's De mulieribus claris, 70; as parallel to Agrippina, 194-95 (n. 41)

Dio Cassius, 58-60, 128, 141-44; as source for Sophonisbe, 37, 40, 47

Diodorus Siculus, as source for Agrippina, 116-19

DuBois, Page, 13-14, 183 (n. 24)

Early modern studies: geography of, 2-3, 22; post-Cold War, 23, 178-79 feminist approaches to, 77-79; in United States, $175-76$

Education: performance of Lohenstein's plays in Protestant, 5, 7, 19-20, 35, 104; and early modern ideology of male identity, 7, 20, 38-39, 58, 81, 100; and Protestant Gymnasien in Breslau, 34-35; and Jesuit Gymnasium in Breslau, 35, 79, 123; and humanist Gymnasien, 41; of early modern women, 106-7
Epicharis, 74; and Seneca, 74; crossdressing of, 84-85; involvement of in Pisonian conspiracy, 85; parallels to Leaena of Athens, 88-92. See also Lohenstein, Daniel Casper vonEpicharis

Ernest (duke of Saxony-Gotha), 133

Ernst (Ernesti), Heinrich, as source for $\mathrm{Ag}$ rippina, 112-14

Ethiopia: Candace, ancient queen of, 12829, 131, 141, 197 (n. 27); political relationship to Egypt, 132; history of Abyssinian kingdom, 132, 135-38, 154; Coptic culture and religion of, 132-36; Monophysite church of, 134, 136; early modern Portuguese presence in, 135-38. See also Ludolf, Hiob

Euphorion, 162

Europe, study of, xi-xii, 2-4

European Community (EC), 4

Eusebius, as source for story of Leaena of Athens, 89-90

Eusebius of Antioch, as parallel to Epicharis, 99

Faber du Faur, Curt, 174

Ferguson, Margaret, 78

Firmus, 99

Flemming, Willi, Benjamin's reference to, 162

Forstner, Christophorus, glosses on Tacitus as source for Epicharis, 97-100, $122-27$

Freud, Sigmund, 13

Garber, Klaus, 163, 199 (n. 3)

Garrulity, female, in Epicharis, 86-92, 98100

Geertz, Clifford, 16-17

Gender, in early modern Europe, 1, 8, 2122, 83-84, 96, 106, 159; and philology, $11-12,20-21$

George William (Georg Wilhelm, Piastian prince), 31-32, 102-4

Ginzburg, Carlo, 16-17, 47

Glareanus, Heinrich, 44

Godelevaeus, Wilhelm, 56

Grafton, Anthony, 78, 15, 183 (n. 39), 185 (n. 70)

Greaves, Jean, Description des Pyramides 
D'Egypte (1663), as source for Cleopatra, $155-58$

Greene, Thomas, 46-47, 184 (n. 60), 186 (nn. 8, 13)

Greetham, D. C., 14, 165, 184 (n. 66)

Gregory, Abba (Ethiopian bishop), 133-37

Gronov, Jacob (Gerhard Haverkamp), as source for Agrippina, 113-14

Gronovius, Johann, Titi Livii Historium Quod Extat (1643), as source for Sophonisbe, 44-46, 55-56

Grotius, Hugo, 134

Gruter, Janus, 56

Gryphius, Andreas, 95, 163-65

Guillory, John, 6, 16, 182-83 (n. 23)

Gymnasien. See Education

Habsburg, House of, 26-27, 30, 51

Hall, Kim F., 131

Hallmann, Johann Christian, 164-65

Halpern, Richard, 20, 78-79, 182 (n. 13), 184 (n. 64), 185 (n. 71)

Hampton, Timothy, 186 (nn. 7, 12), 187 (nn. 21, 22)

Hannibal, 39, 63, 68, 74, 141

Haraway, Donna, 9

Hausenstein, Wilhelm, Benjamin's citation of, 162

Hayles, N. Katherine, 5-6, 9-10, 182 (nn. 9, 11), 183 (n. 25)

Hendreich, Christophorus, De Respublica Carthaginensium (Concerning the Carthaginian Republic) (1664), as source for Sophonisbe, 69-70

Hendricks, Margo, 77, 131, 197 (n. 32)

Hermite, Tristan 1', La Morte de Sénèque (The death of Seneca) (1644), as source for Epicharis, 93

Herodotus, as source for Agrippina, 117-20

Hexter, Ralph, 63, 187-88 (nn. 37, 39, 41,42 )

Hiersemann Verlag, xv, 169-74

Historiography, Roman, 18-19, 38; theories of, 39-40, 73. See also Justinus, Marcus Junianus; Livy; Tacitus

Holy Roman Empire, 17, 18, 34, 39, 58, 71, 102, 104

Horst, Carl, Benjamin's reference to, 162

Howard, Jean, 182 (n. 15)
Hübscher, Arthur, Benjamin's citation of, 162

Hughs-Hallett, Lucy, 155, 197 (n. 31), 198 (nn. 41, 52)

Incest, 101; as political strategy, 108-10, 125; scenes of in Agrippina, 109; in Persian law, 109-10, 113; among ancient Greeks, 111-13

Irigaray, Luce, 39

Jakobson, Roman, 12; philology as "slow reading" theory of, 12, 38, 73, 102, $158-59$

Jardine, Lisa, 78

Jed, Stephanie, 12, 15, 105, 127

Jerome, 118

Johnson, Barbara, 13-14

Journal des Scavans, Le, as source for Cleopatra, 157

Just, Klaus Günther: edition of Lohenstein's plays, xv, 14, 160, 165-71; "Register" by of works cited by Lohenstein, 97, 154, 167, 186 (n. 14); interpretation of Agrippina by, 109-11; interpretation of Cleopatra by, 130, 197 (n. 34); biography of, 165-66; correspondence of with Hermann Schneider, 167-69; Silesian "patriotism" of, 172

Justinus, Marcus Junianus: as source for Agrippina, 115-16, 117-20; Bernegger edition of, 118-20; as source for Sophonisbe, 119, 194 (nn. 36, 37); early modern editions of, 194 (n. 40)

Justinus Frontinus, as source for Sophonisbe, 66-68, 70

Kahn, Coppelia, 184 (n. 59)

Kelly, Joan, 77-78

Kenney, E. J., 16

King, Katie, 10, 12

Kircher, Athanasius, 48, 69, 116-17, 156, 158, 196 (n. 4)

Kristeller, Paul O., 3

Kühlmann, Wilhelm, 105, 185 (n. 2), 188 (n. 52), 195 (nn. 43, 44)

Lactantius, 89-90

Leaena of Athens, 88-92, 96, 99-100

Le Moyne, Pierre, La Galerie des femmes 
fortes (Gallery of strong women) (1647), as source for Agrippina, 107-8

Leopold I (Emperor), 46

Levine, Laura, 182 (n. 15), 189 (n. 3)

Lipsius, Justus, C. Cornelii Taciti Opera Quae Existant (Extant works of Tacitus) (1668), as source for Epicharis, 97-100

Livy: as source for Sophonisbe, 37, 40, 43, $47,52-58,60$; Gronovius edition of, $43-$ $47,55-58,68-69,98$; illustrations of in early modern editions, 52-54; early modern editions of, 56; early modern political reception of, 57; editio princeps of, 57

Lohenstein, Daniel Casper von: Roman plays of, 5-6, 11, 17-18, 37; as Syndikus of Breslau, 6-7, 17, 19, 34, 39, 42, 94, 105, 191-92 (n. 2), 192 (n. 10); staging of plays of, $7,19,79,101$; Szenare (program notes for plays), 51, 79, 109

-Agrippina (1665): incest in, 101, 103, 109; ancient and premodern sources of, 101, $110-12,114-19,122-27$; production of, 101-2, 109-10, 122-23; early modern sources of, 107; early modern editions of ancient sources of, 111-14, 118-27; frontispiece of, 118

-Cleopatra (1680): ancient sources of, 128, 141-42, 144; medieval and early modern sources of, 128-29, 131-38, 143-46, 153-55; difference from 1661 version of, 128-30, 141, 154; scenes of disguise in, 140, 143; production of, 141-42; crossdressing in, 142-43, 158; comparison with Benserade's La Cleopatre, 143-46, 157-58; blazon in, 146-51

_Epicharis (1665): staging of, 74, 87, 95; frontispiece of, 75-76, 80; torture in, 75-76, 80, 86, 93-99; ancient sources of, $76,84,93-94,96-100$; sources in Desmarets de Saint-Sorlin, 84 ; crossdressing in, 85, 94-95, 100; early modern sources of, 88-94, 96

-Sophonisbe (1669): staging of, 7; prologue of, 37-47; cross-dressing in, 47-58, 68; constraints on production of, 51,80 ; ancient sources of, 51-57; hybrid gender ideology in, 58, 69; figurations of Holy Roman Empire in, 59-60, 71; intertextual references to Virgil's Aeneid in, 60-
64; alternative early modern versions of, 64-65, 186 (n. 5)

Lord, Mary Louise, 61

Louise (duchess of Liegnitz, Brieg, and Wohlau), 102-9, 111, 121-27; relationship to Lohenstein of, 105

Lucae, Friedrich, 189 (n. 18), 192 (nn. 3, $5,8)$

Lucretia, 42, 66, 145

Ludolf, Hiob: and early modern Ethiopian Studies, 133-38, 154-58; ecumenicalism of, 134

Lunding, Erik, 164, 183 (n. 28), 193 (n. 19)

Lupton, Julia Reinhard, 199 (n. 1,3)

McGann, Jerome, 14, 165

Maclean, Ian, 108, 189 (n. 6), 190 (nn. 24, 37), 192 (n. 6), 193 (nn. 17, 18), 194 (n. 38)

Marcus, Leah, 181 (n. 3), 183 (n. 26)

Martino, Alberto, 183 (n. 29)

Massinissa, 49-58, 70, 73

Materiality of texts, 6, 7, 19, 55-56

Migiel, Marilyn, 78

Moors, 124, 131, 140-41, 148-49, 152, 154

Müller, Conrad, 11, 162

National Socialism, 24, 163-66

Nepos, Cornelius: as source for Agrippina, 111-14, 121; Ernst edition of, 112-14; van Staveren edition of, 112-14, 121; Boecler commentary on, 121-22

Nero: in Pliny, 81-83; in Tacitus, 84, 93; in Epicharis, 85, 87, 95, 97; in 1'Hermite, 93; in Agrippina, 101-2, 106, 109-11, $114-$ $15,120-27$

Neumann, Friedrich, 181 (n. 5)

New World, exploration of, 32, 156

Ninus (husband of Semiramis), 116-17

Ninyas (also Ninus, son of Semiramis), 113-20

North Atlantic Treaty Organization (NATO), $x i$

Ong, Walter, 20, 189 (n. 3)

Orosius, 118-19

Panofsky, Erwin, 162

Parker, Patricia, 77

Pausanius, 89-90

Peters, Edward, 94 
Petersen, Julius: and Benjamin, 162

Petrarch, Francesco, 47; L'Africa (1338), 6465; Trionfi (Triumphs) (c. 1340), 65

Petrarchism, 144-50

Philippson, Ernst Alfred, 169-71

Philology: gender and, 11-12, 20-21; critiques of, 13-14; history of classical through contemporary, 15-19; and ethnography, 16; early modern political, $38,105,121-27$; Benjamin's concept of, 161-63; history of modern German, 168-69. See also Geertz, Clifford; Jakobson, Roman; Saussure, Ferdinand de; Wolf, Friedrich August

Piastians, 24, 26-27, 30-32, 35-36, 104$5,108,122$. See also George William; Louise

Pisonian conspiracy: representation of in Epicharis, 74; ancient sources on, 74, 84, 96-97

Pliny (the Elder), 81-82, 89-92, 96, 100

Plutarch, 106; as source for Agrippina, 11720; as source for Cleopatra, 128, 141, 152

Pocock, J. G. A., 181 (n. 6)

Poland: twentieth-century, xi, 23-25; preand early modern, 2, 24-25, 28, 32, 169, $172-73,178$

Polynaeus, 89

Pompeius, Trogus. See Justinus, Marcus Junianus

Portia, 145

Pratt, Mary Louise, 9

Presentism, 10

Proculejus (Augustus Caesar's representative), 147-51

Ptolemy, House of, 131, 141, 152-57

Punic Wars, 37-40, 49, 63

Quint, David, 63, 188 (nn. 43, 51), 197 (nn. 28, 36)

Quintilian, 40-41

Race: early modern identity of, $130-31$, 138-39, 158; and early modern AfricanEuropean relations, 133-40; and use of term, 195 (n. 1)

Rauchmüller, Matthias, 53

Relations de divers voyages curieux (Accounts of several remarkable journeys) $(1663,1666), 154-57$
Renaissance studies, 2-3, 175-77, 181

(n. 3); feminist approaches to, 77-78

Rhenanus, Beatus, 45, 56

Riffaterre, Michael, 26, 197 (n. 26)

Rizzo, Silvia, 16

Rosenzweig, Franz, 162

Rubin, Gayle, 82

Salic Law: in France, 104; inapplicability of in Silesia, 104

Samuel, Irene, 118

Sandrart, Joachim, 54

Saussure, Ferdinand de, 16

Saxl, Fritz, 3, 162

Schiesari, Juliana, 78

Schlesinger, Maximilian, 101, 189 (n. 16)

Schneider, Hermann, 167-70, 173

School drama (Schuldrama), 4-5, 17, 20, 39, $141,184-85$ (n. 69 )

Schurmann, Anna Maria van, 106

Scott, Joan, 82

Second Silesian School (Zweite Schlesische Schule), 159, 162, 164

Sedgwick, Eve, 1

Selden, John, 48, 69-70, 156

Semiramis: in Agrippina, 103, 106, 108-10, 114-15, 118-24; cross-dressing of, 107, 114-15, 117; in Le Moyne's Galerie des femmes fortes, 107-8; ancient sources on, 113-14, 116-21; as regent for Ninus, 114, 116-17, 123; early modern sources on, $114-15$

Seneca, 74-75, 80, 109

Shakespeare, William, 143, 185 (n. 1), 190 (n. 34), 198 (nn. 43, 45, 48)

Sigonius, Carolus, 56

Silesia: post-World War II history of, 2324, 172-73; pre- and early modern history of, 23-36; confessional history of, $28-30$. See also Piastians; Women rulers

Silius Italicus, as source for Sophonisbe, 47,68

"Slow reading." See Jakobson, Roman

Sophonisbe (of Numidia), 37, 39; gendered identity of, 52-55; parallels to Dido, 6263. See also Lohenstein, Daniel Casper von-Sophonisbe

Spellerberg, Gerhard, 84, 187 (nn. 20, 27), 188 (n. 55), 192 (n. 3), 197 (n. 34), 200 (n. 13) 
Spon, Jacob, A Voyage to Italy, Dalmatia, Greece, and the Levant (Voyage d'Italie, de Dalmatie, de Grece, et du Levant) (1678), as source for Cleopatra, 156-57

Stammler, Wolfgang, 168

Steiner, Uwe, 161, 163, 199 (nn. 3, 5)

Strich, Fritz, 162

Suetonius, 101, 106, 128

Syphax, 48, 50, 51

Tacitus: as source for Epicharis, 84-88, 91100; Lipsius edition of, 97-100; Annals, Forstner edition and commentary on, 97-100, 122-27; as source for Agrippina, $101,110,122-27$

Tanselle, G. Thomas, 165

Tarquin, 42

Tertullian, 89-92, 97, 113

Theodoretus, 113

Theory: postmodern, 2, 9, 10; textual, 8,12 , 14-15, 20, 69, 165; gender, 9

Thirty Years War, 30, 33-34, 104, 122, 185 (n. 77)

Tiraquellus (Tiraqueau), Andreas, De Legibus Connubialibus, et Jure Maritali (On the laws of wedlock and marital law) (1515), as source for Epicharis, 8892, 96-100

Tittmann, Julius, Benjamin's reference to, 162

Torture: representations of, 75-76; early modern regulation of, 94. See also Lohenstein, Daniel Casper von-Epicharis
Tribble, Evelyn B., 184 (n. 65)

Trunz, Erich, 164

Valerius Maximus, 98-100

Van Staveren, Augustus, 112-14

Vickers, Nancy, 198 (n. 44)

Virgil: Aeneid, references to in Sophonisbe, 59-64, 66-67, 70, 197 (n. 36); early modern editions of, 60, 68; references to in Agrippina, 194 (n. 41)

Vossius, Gerhard Johannes, 56

Wansleben, Johann Michael: Nouvelle Relation en Forme de Iournal, d'un Voyage fait en Egypte (New Account in journal form of a trip to Egypt) (1677), as source for Cleopatra, 128, 130-38, 154, 157; relationship to Hiob Ludolf of, 133-37

Warburg, Aby, 3, 162

Wende ("turn," events in Europe of 1989), $\mathrm{xi}, 3,178$

Wichert, Adalbert, 182 (n. 12), 183 (n. 29), 184 (nn. 61, 62), 187 (n. 26), 188 (n. 38), 189 (nn. 16, 17), 190 (n. 27), 191 (n. 2), 192 (nn. 5, 10), 193 (n. 21)

Wolf, Friedrich August, 15

Women rulers: in Silesia, 21, 102-6, 108; sexual behavior of, 103, 108; education of, 106

Zeno (the Stoic), 99-100

Zetzel, James, 15 



